Gustavo Ferraz de Campos Monaco

\title{
ATRIBUIÇÃO DA GUARDA E SUAS CONSEQÜÊNCIAS EM DIREITO INTERNACIONAL PRIVADO
}

Tese de Doutorado

Universidade de São Paulo

Faculdade de Direito

São Paulo

2008 
Gustavo Ferraz de CAMPos Monaco

\section{ATRIBUIÇÃO DA GUARDA E SUAS CONSEQÜÊNCIAS}

EM DIREITO INTERNACIONAL PRIVADO

Tese de Doutorado apresentada à Banca Examinadora da FACUlDADE DE DIREITO DA UNIVERSIDAdE DE SÃo PAULO, como exigência parcial para a obtenção do título de Doutor em Direito, sob a orientação do Professor Doutor JoÃo GRANDINO RODAS.

Universidade de São Paulo

Faculdade de Direito

São Paulo

2008 
Banca Examinadora 
Para Isis, Nuno e Joana,

sem cuja presença a vida teria significação meramente formal. 
Meus agradecimentos: ao Professor João Grandino Rodas que, desde a iniciação científica, confiou em meu trabalho; ao Professor Rui Manuel Gens de Moura Ramos que me acolheu como mestrando em Portugal, onde colhi grande felicidade acadêmica e intelectual;

a Fundação de Amparo à Pesquisa do Estado de São Paulo que custeou esta pesquisa, como custeou, no passado, minha iniciação científica. 
Eu acho que o maior obstáculo para atingir a liberdade é o trabalho que ela dá. (António Alçada Baptista)

Sempre que estamos tristes, ou cansados, ou simplesmente ocupados (por dentro), ficamos com menos espaço para nos darmos àqueles que se nos dão e, não sendo maus, fazemos-lhes mal (simplesmente porque, de fugida, os fazemos sentir abandonados). Qualquer um de nós já foi, portanto, abandonado, como é, potencialmente, abandonante. As crianças percebem-no bem quando, zangadas pela sua distracção em relação a elas, dizem aos pais: "já não gosto mais de ti!"

(Eduardo Sá) 


\section{$\underline{\text { R E S U M O }}$}

A presente tese diz respeito à análise das hipóteses de atribuição da guarda dos filhos incapazes de pessoas que, por alguma razão, vivam separadamente, desmanchando eventual vínculo familiar entre elas existente. Como esse fato não é apto a desfazer os vínculos entre cada um dos genitores e seus filhos, torna-se imperiosa a atribuição da guarda a um ou a ambos os pais (guarda simples, alternada ou compartilhada). A análise da questão toma em consideração os casos com elemento estrangeiro, ou seja, com algum fator que possa desvincular o caso fático de sua subsunção exclusiva ao ordenamento jurídico nacional, ligando-o, potencialmente, a outro ordenamento jurídico, quer pelo fato de um dos pais ser nacional de ou domiciliado em Estado estrangeiro, quer porque a criança seja estrangeira, ou, ainda, por um dos genitores manifestar a intenção de passar a residir no exterior, mesmo que todos os elementos até então existentes indicassem conexão exclusiva com o ordenamento brasileiro. Além da atribuição da guarda, outras consequiências podem advir dessa relação fática, como a manutenção ou não do poder familiar, a regulamentação do direito de visitas, a estipulação do valor da pensão alimentícia etc.

Torna-se necessário, assim, decidir qual a lei aplicável para a regulação da questão, bem como de suas conseqüências imediatas, vale dizer, a regulamentação do regime de visitas para o genitor afastado da convivência diuturna com os filhos, além da fixação da quantia necessária para a subsistência das crianças, por meio da pensão alimentícia a que façam jus.

$\mathrm{O}$ estudo considera o direito à convivência familiar plena enquanto princípio maior e reitor da questão. O tema envolve, assim, uma série de institutos jurídicos ligados, em última análise, à proteção da criança em suas relações privadas (familiares), sejam elas de âmbito eminentemente pessoal, sejam, por outro lado, de âmbito patrimonial, englobandose, desse modo, os direitos humanos e o direito internacional privado.

Levou-se em conta o direito internacional privado convencional existente, mas ainda não ratificado pelo Estado brasileiro, indicando a eventual pertinência no que respeita a uma futura ratificação. A existência de uma série de convenções internacionais sobre o tema ainda não ratificadas pelo Brasil exigiu uma análise da questão não apenas do ponto de vista do direito interno, mas também, e principalmente, relativa à regulamentação sugerida pela sociedade internacional.

O objetivo maior foi dar tratamento sistemático à matéria e indicar ao legislador nacional e ao Poder Executivo - dotado de competência para representar o país nas relações internacionais - um caminho que pode ser seguido pelo Estado brasileiro no que concerne à ratificação ou não dos tratados internacionais existentes sobre o assunto.

A falta de estudos sistemáticos no Brasil a respeito do tema tem o condão de justificar a escolha empreendida, indicando a sua importância e sua originalidade, mormente quando se pretende indicar aos órgãos competentes as vantagens e/ou desvantagens que o sistema é capaz de proporcionar, seja na eleição do elemento de conexão posto em relevo para a escolha da lei aplicável à hipótese, seja nos aspectos procedimentais e de cooperação internacional envolvidos. 
O trabalho, em razão dos preceitos legislativos abrangidos, exigiu fossem seguidas duas metodologias distintas: uma de raiz e cunho dogmáticos a respeito dos institutos jurídicos conexos à questão e outra, de raiz e cunho comparativos a respeito da colação entre os sistemas existentes, qual seja, o sistema vigente no país e o sistema indicado pela sociedade internacional como o mais adequado para regular a questão.

O método comparativo não se confunde com a mera descrição dos ordenamentos jurídicos (nacional e internacional), exigindo, isso sim, a análise de cada um dos fatores considerados relevantes em ambos os ordenamentos, procedendo-se a quadros comparativos que permitam ao intérprete atingir qual o sistema legislativo mais adequado para a hipótese. Não é recomendável, na aplicação de tal método, a análise de muitos ordenamentos jurídicos, daí por que a limitação do trabalho. Assim, não se perverte o método, conservando-se a cientificidade que o trabalho visou realizar.

\section{U N I T E R M OS}

Direito internacional privado - direito internacional privado convencional - guarda alimentos - direito de visita - poder familiar - administração de bens dos filhos menores elemento de conexão - qualificação - cooperação internacional - direito comparado. 


\section{A B S T R A C T}

The present thesis concerns the analysis of hypotheses on attributing the custody of children to people who, for some reason, live separately, undoing the possible family bond existing between them. As this fact is cannot undo the bonds between each of the parents and their children, the attribution of custody to one or to both parents (simple, alternate or shared custody) becomes imperious. The analysis of the matter takes into consideration the cases with a foreign element, that is, with a factor that may disentail the phatic case from its exclusive subsunction to the national legal system, potentially linking it to another legal system, be it for the fact of one of the parents being a foreign citizen or domiciled in a foreign country, be it for the child being a foreigner, or, still, for one of the parents manifesting the intention of living abroad, even if all the elements existing until then indicate exclusive connection with the Brazilian legal system. Besides the attribution of custody, other consequences may derive from this phatic relationship, such as the maintenance or not of the family power, the regulation of visit rights, the stipulation of the fee, etc.

It turns thus necessary to decide what law is applicable to regulate the matter, as well as their immediate consequences, that is, the regulation of the visit regime for the parent removed from the daily coexistence with the children, besides the establishment of the necessary sum for the children's subsistence, by means of the alimony they are entitled to.

The study considers the full family coexistence right, while a major principle and ruler of the matter. The theme thus involves a number of legal institutions, in a final analysis, linked to children protection in their private (family) relationships, either of eminently personal ambit, or, conversely, of patrimonial ambit, thus comprehending human rights and private international law.

The work took into consideration conventional existing private international law, not yet ratified by Brazil, indicating the possible pertinence concerning a future ratification. The existence of a number of international conventions on the theme, not yet ratified by Brazil, required an analysis of the matter, not only from the point of view of domestic right, but also - and mainly - related to the regulation suggested by international society.

The major purpose was to provide a systematic treatment to the matter and to indicate to the national lawmaker and to the Executive Power - endowed with competence to represent Brazil in international affairs - a path that may be followed by Brazil concerning the ratification or not of the existing international treaties on the matter.

The lack of systematic studies on the theme in Brazil have the prerogative of justifying the choice undertaken, indicating its importance and originality, specially when intending to indicate to the competent organisms the advantages and/or disadvantages the system is capable of providing, be it in the choice of the connecting factor detached for choosing the law applicable to the hypothesis, be it in the procedural and international cooperation aspects involved.

The work, owing to the legislative rules encompassed, required two distinct methodologies to be followed: one of dogmatic root and character with respect to the legal institutions connected to the matter and another, of comparative root and character with 
respect to the collation of the existing systems, which is the system in force in Brazil and the system indicated by the international society as the most adequate to regulate the matter.

The comparative method is not to be confounded with the mere description of (national and international) law systems, but one requiring the analysis of each of the factors considered relevant in both systems, referring to comparative tables that allow the interpreter to decide on the most adequate legal system for the hypothesis. In the application of the method, the analysis of different legal systems is not advisable, hence the limitation of the work. Therefore, the method is not perverted, preserving the scientificity aimed at by the work.

\section{U N I T E R M S}

Private international law - conventional private international law - custody - alimony visit right - family power - management of minor children's assets - connecting factor qualification - international cooperation - comparative law. 


\section{$\underline{\text { R E S U M É }}$}

Cette thèse traite de l'analyse de hipothèses de l'attribution de la garde des enfants incapables de personnes ne pouvant plus les élever en commun. Les raisons peuvent être diverses: soit ce couple vit séparément, soit les attaches familiales ont été rompues.

Dans ces deux cas, ces enfants conservant leurs attaches familiales seront pris en charge soit par la mère, le père ou le couple (garde simple, alternée ou responsabilité parentale conjointe).

L'analyse en question prend en compte les cas particuliers où interviennent deux pays, c'est à dire un facteur qui ne dépend plus exclusivement d'un ordonnancement national mais qui peut appartenir à un ordonnancement étranger, soit qu'un des parents ait la même nationalité que l'enfant mais vit à l'étranger, soit que l'enfant ait la nationalité étrangère, soit encore que l'un des conjoints désire s'installer á l'étranger, même si tous les éléments jusqu'à présent indiquaient une appartenance exclusive à un ordonnancement brésilien.

Hors l'attribution de la garde, il y a bien d'autres conséquences telles que le maintien ou non de l'autorité parentale, le réglement du droit de visites et le montant de la pension alimentaire.

Il est essentiel de définir la loi qui doit être appliquée afin de trouver une solution acceptable, règlant ainsi les conséquences immédiates; d'une part, en octroyant le droit de visite au parent éloigné qui ne participe plus aux responsabilités quotidiennes de l'éducation des enfants et d'autre part en définissant le montant de la pension alimentaire nécessaire.

L'étude considère également le droit de l'enfant à cohabiter pleinement avec les deux parents, étant reconnu comme principe et valeur absolue.

Le sujet vise aussi à l'étude des institutions juridiques liées à la protection de l'enfant dans le domaine privé (familial) en tenant compte non seulement des droits humains mais des droits patrimoniaux, dans un contexte respectant le droit international privé.

Pour initier ce travail, on a pris comme point de départ le droit international privé conventionnel déjà existant, non ratifié au Brésil, mais qui pourrait être pertinemment adopté lors d'une future ratification de l'État brésilien.

L'existence d'un grand nombre de conventions internationales à propos de ce thème, pas encore ratifiée par le Brésil, a exigé une analyse non seulement d'un point de vue interne mais aussi et en priorité une analyse relative à la réglementation suggérée par la société internationale.

Le but de ce travail a été celui de donner une idée de système à la matière e indiquer au legislateur national et au Pouvoir Éxecutif - autorisé pour représenter le pays dans les relations internationales - une suggestion de chemin à être suivi par l'Etat brésilien en ce 
qui concerne la ratification ou non des tratés internationaux existants.

L'importance et l'originalité du choix du thème en question remplit l'absence des études systématiques au Brésil, ce que colabore pour indiquer les avantages et les dévantages de ce systhème aux pouvoirs compétants, soit par l'élection du élement de connexion élu par le choix de la loi aplicable à l'hipothèse, soit par l'aspect de la procedure et de la coopération internationale y comprise.

Le travail est orienté vers deux méthodologies: l'une de racine dogmatique à propos des instituts juridiques connexes à la question en analyse, et l'autre, qui compare les systèmes existants, c'est à dire, le système en vigueur dans le pays et le système indiqué par la société internationale comme le plus adéquat pour régler la question.

La méthode de droit comparer ne se limite pas à la decription des ordonnancements juridiques (national et international), mais il exige l'analyse de chaque aspect en relief, dans les deux systèmes, avec le but de guider l'interprète au choix du système legislatif plus adéquat à l'hypothèse. Le limite de la recherche est donné à la préocupation scientifique de fond et non seulement à la méthode, donc, il ne convient pas comparer plusieurs ordonnancements juridiques.

\section{U N I T E R M E S}

Droit international privé - droit international privé conventionnel - garde - pension alimentaire - droit de visite - autorité parentale - administration des biens des enfants mineurs - élement de connexion - qualification - coopération internationale - droit comparer. 


\section{S U M Á R I O}

Resumo

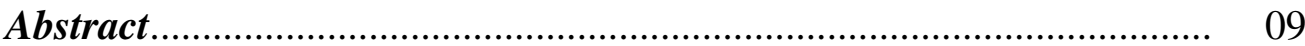

Resumé

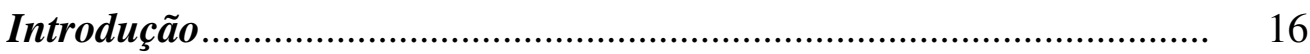

Primeira Parte

DIREITO INTERNACIONAL PRIVADO:

PROBLEMAS TEÓRICOS FUNDAMENTAIS RELACIONADOS À GUARDA DE FILHOS

Capítulo A qualificação da guarda como antecedente para a aplicação do

I. método próprio ao direito internacional privado.................................... 27

1. Qualificação da relação jurídica em direito internacional privado............. 27

1.1. Relações familiares no direito brasileiro: introdução................................. 34

2. A atribuição da guarda..................................................................... 42

2.1. A escolha do sistema de atribuição da guarda......................................... 43

2.1.1. Guarda unilateral............................................................................. 44

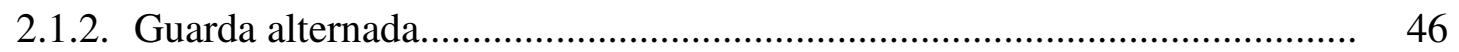

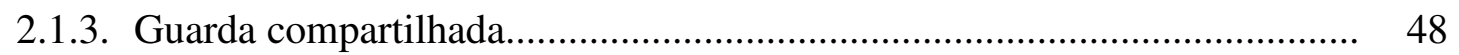

2.2. A escolha do guardião....................................................................... 50

3. Conseqüências da atribuição da guarda.................................................... 60

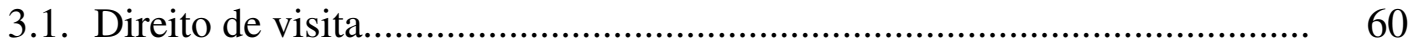

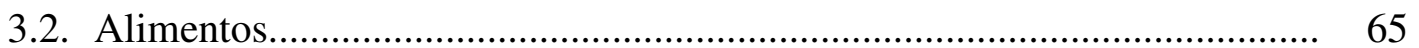

3.3. Administração dos bens de filhos menores............................................... 68

4. Exercício do poder familiar na desunião das famílias............................... 69

Capítulo Direito internacional privado e guarda de filhos: método, justiça e

II. permeabilidade a valores.............. 71

1. Estrutura da norma, método do direito internacional privado e preocupação com o direito substancial: análise teórica aplicada às relações familiares.......................................................................... 71

1.1. Normativismo, classicismo e segurança jurídica..................................... 77

1.2. Flexibilidade e tentativa de realização de justiça por meio da aplicação das normas de direito internacional privado.

2. Conteúdo da relação familiar e reflexos na concepção do método do direito internacional privado: tomada de posição teórica e pragmática...... 
Segunda Parte

A GUARDA DE FILHOS E SUAS CONSEQÜÊNCIAS

NO DIREITO INTERNACIONAL PRIVADO BRASILEIRO LEGISLADO

E NO DIREITO INTERNACIONAL PRIVADO CONVENCIONAL

Capítulo A verificação da lei aplicável no direito internacional privado brasileiro

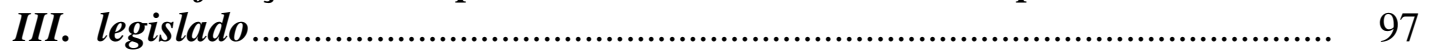

1. Manutenção dos membros da família em território nacional...................... 99

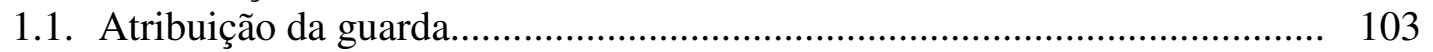

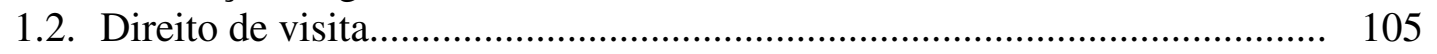

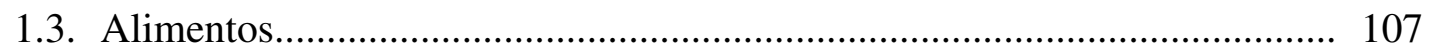

1.4. Administração dos bens de filhos menores............................................. 107

1.5. Exercício do poder familiar na desunião das famílias................................ 109

2. Separação transfronteiriça dos membros da família e exceções à aplicação

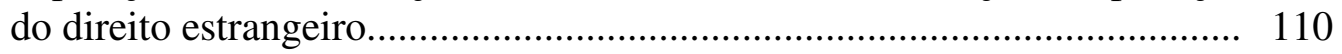

2.1. Atribuição da guarda................................................................................ 116

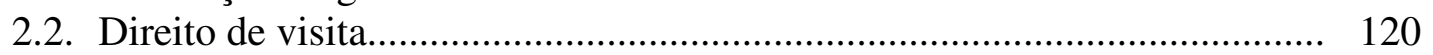

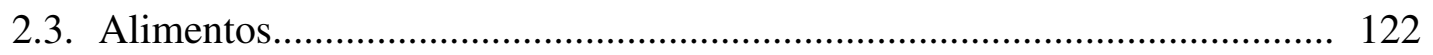

2.4. Administração dos bens de filhos menores.............................................. 125

2.5. Exercício do poder familiar na desunião das famílias................................. 126

3. Alteração posterior das situações fáticas................................................... 126

3.1. Separação transfronteiriça dos membros da família que permanecia no mesmo território............................................................................. 126

3.2. Reunião dos membros da família em território nacional............................ 129

\section{Capítulo}

IV. Regulação do tema pela sociedade internacional

1. A Convenção da Haia concernente à competência, lei aplicável, reconhecimento, execução e cooperação em matéria de responsabilidade parental e medidas de proteção da criança, de 1996.

2. A Convenção da Haia sobre os aspectos civis do seqüestro (subtração) internacional de crianças, de 1980.

3. A Convenção interamericana sobre restituição internacional de menores, de 1989

4. A Convenção da Haia sobre a lei aplicável às obrigações alimentares, de 1973.

5. A Convenção da Haia sobre o reconhecimento e a execução de decisões relativas a obrigações alimentares, de 1973

6. A Convenção da Haia sobre cobrança de alimentos destinados às crianças e a outros membros da família.

\section{Capítulo}

V. A comparação entre os sistemas e a indicação de um caminho a seguir.. 169

1. A harmonização internacional dos institutos jurídicos ou os reflexos da ratificação das convenções internacionais no sistema jurídico material.... 169

2. A escolha da lei aplicável ou os reflexos da ratificação das convenções internacionais no sistema de direito internacional privado...... 
3. A execução das decisões internacionais ou os reflexos da ratificação das convenções internacionais no sistema processual..

4. A cooperação internacional ou os reflexos da ratificação das convenções internacionais na organização do Estado................................................... 175

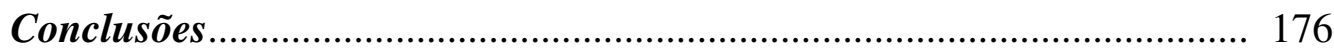

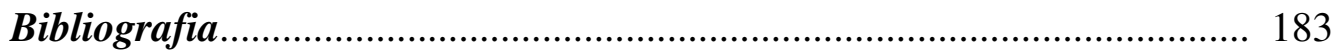

Anexo Lista das principais convenções analisadas e indicação dos sítios de publicação virtual na rede mundial de computadores... 


\section{INTRODUÇÃO}

O método próprio ao direito internacional privado exige prévio reconhecimento das relações jurídicas que demandam sua intervenção pela razão de apresentarem elemento fático que guarda pertinência espacial com um ou mais ordenamentos jurídicos estrangeiros quaisquer. Essa particularidade da relação jurídica faz surgir dúvidas a respeito de qual dos ordenamentos normativos envolvidos merece ser aplicado quando, em tese, ambos se mostrem potencialmente aplicáveis.

A potencialidade de aplicação de mais de um ordenamento jurídico (seja o ordenamento nacional - do foro competente -, seja um dos ordenamentos estrangeiros estranhos ao ordenamento do foro competente) constitui conflito aparente de normas que merece ser solucionado segundo critérios de segurança e certeza que se ligam, em última análise, à escolha normativa cristalizada após séculos de discussões sobre qual elemento de conexão se deve privilegiar. No entanto, a crescente complexidade das relações sociais e seus reflexos na seara jurídica do indivíduo levam parte cada vez mais considerável da doutrina privatista internacional a considerar certo grau de flexibilização na adoção irrestrita do método puramente normativista, dando vazão, em consequiência, a uma série de possibilidades que precisam ser encaradas e discutidas à luz do objeto central do presente estudo ${ }^{1}$.

\footnotetext{
${ }^{1}$ Exemplifique-se, por ora, com a afirmação de JAYME, Erik. Identité culturelle et intégration: le droit international privé postmoderne. Recueil des Cours, Dordrecht/Boston/Lancaster, v. 251, p. 9-268, 1995, p. 251-252, no sentido de ser uma das preocupações atuais do direito internacional privado a proteção dos direitos fundamentais das pessoas envolvidas em relações com elementos estrangeiros, mormente aquele direito à diversidade cultural, podendo-se, por isso, falar com maior adequação em conflito de culturas em vez de conflitos de leis. Defendendo uma visão sociológica do direito internacional privado, DÉPREZ, Jean. Droit international privé et conflits de civilisations - aspects méthodologiques. Recueil des Cours, Dordrecht/Boston/Lancaster, v. 211, p. 9-372, 1988, p. 217, afirma que "mettre en avant l'aspect culturel des conflits de lois, c'est aller très au-delá de la vision habituelle, très juridique, fonctionnelle, mécanique en quelque sorte, du raisonnement conflictualiste". No âmbito das relações entre pais e filhos, presentes as diferenças originadas da diversidade cultural existente entre os genitores, lapidar é a constatação de DYER, Adair. Protecting the right to multicultural education. Revista Española de Pedagogía, ano 49, n. 190, p. 411-418, Sep-dic 1991, p. 411-412: "If the parents live together, the child will easier access to both cultures which contribute to his or her roots. But, if the parents reside in different regions of the same country or in
} 
Quer isso significar que, segundo alguns, não incumbe mais às fontes do direito internacional privado, com exclusividade, proceder à eleição de determinado elemento que se faz presente em dada relação jurídica, e que se refere à estrutura fática da relação - e por isso pode ser dito elemento fático ou relacional -, para elevá-lo à condição de elemento de conexão, um elemento normativo, juridicamente apreciado e considerado como o mais adequado para indicar a regulação material da questão. Assim, conforme essa parcela dos estudiosos da matéria, ao lado dos critérios normativos, dever-se-ia dar espaço à busca de um resultado justo e apto a satisfazer os interesses das partes, transformando o litígio segundo alguns critérios flexíveis e abertos e, por isso, mais próximos do conceito de justiça.

Por óbvio, a escolha normativa não é abandonada definitivamente. Coexistem os sistemas de solução de conflitos. Para Erik Jayme, tratar-se-ia, em verdade, de continuar a aplicar o método normativista, mas com algumas modificações que permitam a escolha, entre diversos elementos possíveis, de um elemento de conexão que se mostre mais apropriado para se conseguir certo resultado material ${ }^{2}$. Sua adequada funcionalidade depende, por certo, da correta análise estrutural da relação jurídica que se esteja a considerar, o que se obtém por meio da qualificação dos fatos sob lide. Isso não significa que a opção deva ser tomada de forma casuística, variável de relação jurídica para relação jurídica, estando aqui configurada a necessidade de certeza e segurança próprias ao direito internacional privado ${ }^{3}$, como forma de se garantir justiça na resolução de todos os casos

different countries, the process of guaranteeing such access for the child becomes more difficult. This is where international treaties come in. For in the absence of co-operation between countries within a treaty framework, guaranteeing access to both cultures in an uncertain exercise. If the child is sent abroad voluntarily, the parent whom (s)he visits may decide that the child should stay there and may seek a change of custody. The judge before whom the case is brought may have a hard time finding that the child should return to another (foreign) culture. The 'best interest of the child', an indeterminate standard even within one culture, may even become an obstacle to the child's welfare when applied by courts in different cultures, between which the child is being shuttled".

2 JAYME. Identité culturelle..., cit., p. 47. Também, JAYME, Erik. Diritto di famiglia: società multiculturale e nuovi sviluppi del diritto internazionale privato. Rivista di Diritto Internazionale Privato e Processuale, Padova, v. 29, n. 2, p. 295-304, 1993, p. 301: "Il diritto internazionale privato attuale è caratterizzato di un compromesso tra le tecniche classiche del richiamo alla legge applicabilie («Verweisungsrecht») e una certa «materializzazione» delle regole per i conflitti di leggi, soluzioni che mirano ad arrivare ad un certo risultato sostanziale".

${ }^{3}$ Como ressalta WATT, Horatia Muir. La codification en droit international privé. Droits: Revue Française de Théorie, de Philosophie et de Culture Juridiques, Paris, n. 27, p. 149-160, 1998, p. 151, com extrema propriedade, o direito internacional privado é ramo jurídico no qual deve grassar a segurança jurídica, porquanto instrumento de realização de uma forma específica de justiça "fondée sur une hiérarchie d'objectifs ou la prévisibilité et la certitude pésent plus lourd que l'équite de la solutions atteinte au fond". Por outras palavras, é dizer que o direito internacional privado reconhece e aplaude o novo paradigma de elaboração normativa, baseado nas cláusulas abertas e na possibilidade de se atribuir aos casos concretos a decisão mais justa possível, transformando-se o conflito material havido entre as partes (HOOGSTRATEN, 
que se mostram assemelhados quando analisados do ponto de vista de sua estrutura interna.

Assim, relações jurídicas estruturalmente idênticas ou assemelhadas merecem a escolha de um mesmo elemento de conexão, variando a solução material para a questão sub judice conforme as características relacionais envolvidas, ou seja, a resolução material do caso a ser solucionado judicialmente dependerá da verificação de seus elementos fáticos, a fim de se perquirir qual o elemento relacional que preencherá o elemento de conexão indicado pela norma. Um exemplo ajudará na elucidação e na visualização dessa análise. Imagine-se uma obrigação contratual simples. Em tal relação jurídica, há alguns elementos necessários para a sua configuração como relação jurídica obrigacional. Assim, sujeitos, objeto, forma, tempo, lugar, circunstâncias negociais são elementos gerais de qualquer relação jurídica que acabam por individualizá-la pelo preenchimento de seus componentes ${ }^{4}$. Desse modo, uma compra e venda entre duas pessoas individualizadas, relativamente a um objeto determinado, tem o condão de tornar única aquela relação jurídica. Se um desses elementos ou quaisquer outros presentes for preenchido por um elemento estrangeiro, será já o caso de se recorrer ao método próprio ao direito internacional privado a fim de se verificar qual a lei aplicável. Essa verificação se faz pela busca - realizada pelo intérprete - do elemento de conexão indicado pela norma jurídica de direito internacional privado aplicável à hipótese fática ${ }^{5}$. Constatado o elemento de conexão, deve-se retornar à relação jurídica a fim de verificar se o seu correlato elemento fático está preenchido por uma realidade nacional ou estrangeira, para se buscar o direito material (nacional ou estrangeiro) que regulará finalmente a questão. Ou seja, nesse exemplo formulado, se o acordo de vontades

M. H. van. La codification par traités in droit international privé dans le cadre de la conférence de la Haye. Recueil de Cours, La Haye, v. 122, p. 337-425, n. III, 1967. p. 344). Mas esse mesmo direito internacional privado não pode prescindir, para sua correta utilização, de um grau relativamente amplo de segurança, certeza e previsibilidade. Daí por que alguns autores critiquem a adoção do elemento de conexão "laços mais estreitos" ou expressões equivalentes em convenções que tenham por intuito a unificação dos elementos de conexão, pois se trata mais de um princípio ou de uma direção do que, propriamente, de uma verdadeira regra de conflito. A mesma crítica é endereçada às normas codificadas que trazem a previsão de mais de um elemento de conexão aos quais se possa recorrer sem, entretanto, atribuir-lhes qualquer hierarquia ou mesmo critérios para a opção por um deles. Nesse sentido os argumentos de KESSEDJIAN, Catherine. Codification du droit commercial international et droit international privé: de la gouvernance normative pour les relations économiques transnationales. Recueil des Cours, La Haye, v. 300, p. 79-308, 2002, p. 199. WATT. La codification..., cit., p. 158 atribui essa tendência ao legislador que chama de "lunático". Nota cuja origem é a pesquisa que deu origem a RODAS, João Grandino; MONACO, Gustavo Ferraz de Campos. A Conferência da Haia de Direito Internacional Privado: a participação do Brasil. Brasília: Fundação Alexandre de Gusmão, 2007, p. 87-88.

${ }^{4}$ Tais elementos são chamados por AZEVEDO, Antonio Junqueira de. Negócio jurídico: existência, validade e eficácia. 3. ed. São Paulo: Saraiva, 2000, de elementos gerais do negócio jurídico. Ao lado deles, há também os elementos ditos categoriais, que distinguem as várias relações jurídicas umas das outras, admitindo sua classificação ou sua qualificação jurídica.

${ }^{5}$ Sobre a qualificação em direito internacional privado, veja-se, infra, o item 1 do Capítulo I. 
tiver ocorrido em local estranho ao do território nacional do juiz competente e o elemento de conexão para a hipótese for o local da celebração da avença, dever-se-á retornar à relação para se perquirir onde, enfim, foi celebrada a obrigação, chegando-se, então, à lei material aplicável, que será aquela do local da celebração.

Obviamente, a escolha do elemento de conexão pela fonte normativa do direito internacional privado leva em consideração uma série de fatores a fim de privilegiar aquele elemento de conexão que guarde maior pertinência e que garanta efetiva proximidade do ordenamento afinal aplicável à relação jurídica que se procura solucionar. Bem por isso, seria absurdo admitir que um único elemento de conexão servisse para a totalidade das relações jurídicas, porquanto cada uma delas, apresentando caracteres específicos e cumprindo cada qual uma função social diversa, não poderia admitir um elemento estanque, apto e condizente com a estrutura de um tipo de relação jurídica, mas absolutamente desapegado da realidade de outros tipos de relações jurídicas. O mesmo se diga quanto à escolha de um único elemento de conexão inflexível e que não admitisse, se necessário fosse, um juízo discricionário capaz de garantir, aos olhos do julgador, maior justiça para o caso concreto.

As fontes normativas do direito internacional privado procuram valer-se de critérios classificatórios para separarem as relações jurídicas em grandes grupos que demonstrem certa homogeneidade temática. Valem-se, tais fontes, dos grandes grupos classificatórios das relações privadas ${ }^{6}$, podendo haver alguma subdivisão em razão da natureza mesma das relações. Assim, para relações de direito de família, optam as fontes por um elemento de conexão genérico, podendo especificar algumas espécies de relações afetas a este ramo do saber civilista para lhes emprestar um elemento de conexão diverso, mas condizente com as especificidades daquelas relações eleitas. E nada impede que, para a mesma relação, apresente a norma conflitual um elemento principal de conexão e outros elementos subsidiários que possam, no caso concreto, cumprir a mesma função de modo mais adequado. Bem de ver que a opção, então, normalmente se estabelece de forma subsidiária e afeta a critérios indicados nas fontes normativas, legais, doutrinais ou jurisprudenciais.

Em decorrência dessa realidade presente e assente no direito internacional privado e em

\footnotetext{
${ }^{6}$ Nos países que estruturam a sua legislação de direito privado segundo a influência alemã, as normas de conflito costumam reproduzir "grosso modo toda a sistemática do Código Civil e, com ela, a classificação germânica das situações jurídicas em obrigações, direitos reais, relações de família e sucessões por morte" PINHEIRO, Luís de Lima. Direito internacional privado. 2. reimpr. Coimbra: Almedina, 2005, v. 1, p. 395.
} 
suas fontes normativas e doutrinais, verifica-se que a análise interpretativa da relação fática e a busca do elemento de conexão não se podem realizar sem um passo intermédio representado pela qualificação daquela relação jurídica que se apresenta e para a qual se busca a normativa aplicável. O mesmo se diga quanto às escolas doutrinais flexíveis. Quer isso significar que a descoberta do elemento de conexão e o subseqüente retorno à relação jurídica dependerão, sempre, da qualificação que se dê para aquela situação juridicamente relevante. Saber se se trata de uma relação de direito de família, de uma relação atinente ao direito obrigacional ou a qualquer outra forma de classificação fará com que a resposta prévia para a solução do litígio possa variar de acordo com a qualificação que àquela relação seja emprestada. Como afirma Lima Pinheiro, "é sabido que esta classificação não obedece a um critério unívoco, nem permite uma inserção adequada de todas as figuras. É uma classificação que reparte as matérias em centros de regulação numa óptica pragmática e que reflecte certos elementos culturais",

Em razão dessa realidade aqui brevemente sumariada, optou-se pela elaboração da tese em duas partes distintas e correlacionadas, porquanto complementares, e subdivididas em cinco capítulos. A divisão em duas partes se justifica pelo encadeamento dos capítulos e se refere ao método próprio do direito internacional privado. Com efeito, para que se possa atingir o objetivo principal do trabalho, qual seja, a comparação entre o sistema brasileiro de direito internacional privado atinente à atribuição da guarda de filhos e suas normais consequiências em relações plurilocalizadas e o sistema sugerido pela sociedade internacional, expresso em uma série encadeada de convenções internacionais que tratam da questão e de seus temas correlatos, sentiu-se a necessidade de estabelecer um pano de fundo a respeito dos problemas teóricos fundamentais relacionados à guarda de filhos em direito internacional privado, sem que se perdesse o foco central da pesquisa.

Acredita-se que somente com tal estudo teórico prévio, que pretenderá detectar os problemas atinentes ao objeto de estudo, será possível adentrar o assunto central com o cuidado e a profundidade que ele exige.

Na primeira parte, então, partindo-se do concreto para o abstrato, buscar-se-á analisar os atuais problemas e as principais perspectivas teóricas que se apresentam para o futuro do direito internacional privado. Uma análise desse jaez não pode prescindir de uma abordagem histórica, ainda que pontual e, por isso mesmo, não muito acurada sobre o

\footnotetext{
${ }^{7}$ PINHEIRO. Direito..., cit., v. 1, p. 395.
} 
assunto. Trata-se, em verdade, do arcabouço teórico sobre o qual há de se estruturar a tese que se pretende defender. Justifica-se, assim, a vastidão do material bibliográfico coligido a respeito dos problemas principais do direito internacional privado, tendo-se levantado material pertinente aos rumos e tendências que se espera possa a disciplina enfrentar com a finalidade de apresentar um posicionamento quanto ao seu papel histórico e à sua função primordial, tendo como eixo norteador as relações familiares. Esse o objeto do capítulo II da tese. Sua pretensão é, ao mesmo tempo, analítica e crítica. Não se pretende, no entanto, realizar um exercício prospectivo que vá além daquele relacionado pelos grandes autores do direito internacional privado. Bem por isso, trata-se de um capítulo narrativo que não se esquiva da verificação dessa temática geral, nem das repercussões que causa ou que pode causar relativamente ao objeto central da tese.

Ainda na primeira parte do trabalho, buscar-se-á fazer uma análise da regulação da guarda de filhos e dos institutos correlatos ou afetos àquele instituto central, na perspectiva do ordenamento material brasileiro. Isso se justifica pelo fato de ser o direito internacional privado um ramo didático que se enquadra tradicionalmente no direito público interno dos Estados. Assim, para que a presente tese possa cumprir seu desiderato principal, faz-se mister analisar o instituto na perspectiva nacional, ou seja, dos atores sociais incumbidos da narração, da defesa e da busca de transformação do litígio porventura existente entre os pais das crianças envolvidas, a fim de que possam ter um substrato teórico para sua atuação profissional.

Isso porque a primeira grande questão a se enfrentar diz respeito à competência dos órgãos judiciários brasileiros. À luz do art. 88 do Código de Processo Civil sempre que um dos genitores cogitar requerer a guarda de sua prole e sempre que o réu nessa ação esteja domiciliado no Brasil, ainda que de nacionalidade estrangeira (inc. I), sempre que a decisão judicial implicar a necessidade de cumprimento do dispositivo em território nacional (inc. II), ou sempre que o fato que ensejar o pedido de fixação ou modificação da guarda, do regime de visitas ou do valor fixado para os alimentos se tiver verificado em solo brasileiro (inc. III), competente será o juiz nacional para julgar a demanda, devendo, então, aplicar o direito internacional privado nacional. Não se exclui a possibilidade de que medidas provisórias ou mesmo definitivas relativas à guarda de crianças sejam tomadas por tribunais estrangeiros, devendo aqui produzir a totalidade ou parte de seus efeitos ${ }^{8}$. A

\footnotetext{
${ }^{8}$ Veja-se, a respeito, desenvolvimento no capítulo III.
} 
prática retrospectiva demonstrava que, diante da concorrência de tais decisões, prevalecia corriqueiramente aquela que tivesse sido tomada no país em que a criança se encontrava ${ }^{9}$. Entender tal realidade e acompanhar a evolução vivenciada no plano internacional é uma das preocupações que norteia o desenvolvimento de todo o trabalho, mormente em face das disposições convencionais construídas sobre o tema pelos atores internacionais em oportunidades recentes. Além do que, como se terá oportunidade de demonstrar, no direito convencional a repartição de competências assume importante papel na determinação da lei aplicável. Isso porque a lex fori assume destaque como fator de conexão na matéria. Nesse sentido, o caminho mais curto para se atingir a justiça material - refletida na necessidade de proteção da parte mais fraca da relação - passa pela fixação da competente jurisdição com absoluta atenção para a necessidade mencionada, vale dizer, deve-se fixar a competência dos Estados envolvidos na questão tendo-se em vista quer a maior proximidade com a questão de fato (realização da justiça conflitual internationalprivatrechtliche Gerechtigkeit), quer a solução materialmente mais condizente com os fins colimados pelo Direito (realização da justiça material - materiellrechtliche Gerechtigkeit).

Percebe-se, assim, que zelar pela aplicação correta do método próprio ao direito internacional privado é algo de grande importância e que passa pela correta qualificação do instituto da guarda e dos institutos que dele decorrem, como a prestação alimentícia ${ }^{10}$, a administração dos bens dos filhos menores, o direito-dever de visitação, ainda que, ao final, se decida pela aplicação do direito estrangeiro ${ }^{11}$. Tal temática, abordada no capítulo I da tese, é enfrentada também de uma perspectiva interdisciplinar, colhendo-se alguns dados e algumas observações de obras próprias a outras searas do saber, mormente da

\footnotetext{
${ }^{9}$ Nesse sentido, VERWILGHEN, Michel; HOUTTE, Hans van. Conflits d'autorites et de juridictions relatifs a la protection de la personne du mineur. Revue Belge de Droit International, Bruxelles, v. 15, n. 2, p. $397-$ 432, 1980, p. 407-408.

${ }^{10}$ No que respeita à temática das prestações alimentícias, em que pese não se tratar de consequiência direta da atribuição da guarda, fato é que, no mais das vezes, são fixadas na mesma oportunidade. Mormente quando todas as questões são decididas no bojo do processo que estabelece a desunião dos pais da criança alimentanda. A questão ganha maior relevo quando se tem em tela a disposição de alguns instrumentos internacionais que determinam o deslocamento da competência para a atribuição da guarda do juízo da residência habitual, em favor do juízo competente para julgar o divórcio lato sensu. MARTINY, Dieter. Maintenance obligations in the conflict of laws. Recueil des Cours, Dordrecht/Boston/Lancaster, v. 247, p. 131-288, 1994, afirma, ademais, que "in international cases child support claims are often also connected with status, affiliation or divorce proceedings" (destaque inexistente no original). Assim, a matéria é abordada no presente trabalho, sem que apresente qualquer intenção de esgotar o tema que, por si só, comportaria tese própria.

${ }^{11}$ Assim, tratando do direito belga: VERWILGHEN; HOUTTE. Conflits d'autorites..., cit., p. 398.
} 
psicologia, da sociologia e da psicanálise ${ }^{12}$. Esse posicionamento justifica-se pela nova metodologia empregada no estudo do direito de família brasileiro, não sendo raros os posicionamentos doutrinários que pregam tal forma de enfrentamento da realidade familiarista nacional ${ }^{13}$. Ademais, como ficará demonstrado no decorrer da primeira parte, a correta aplicação do método próprio ao direito internacional privado dependerá da tomada de posição que se queira fazer à luz dos recentes posicionamentos doutrinários, legislativos e jurisprudenciais havidos na Europa, nos Estados Unidos (e no Brasil - se bem que aqui ainda em escala muito diminuta e restrita a parte da doutrina) e que tem deixado os países latino-americanos, outrora na vanguarda da disciplina, em sua retaguarda ${ }^{14}$. Nesse sentido, parece conveniente discutir se o que se busca com a nova estruturação sócio-psíquica da família e sua regulação jurídica poderá ou deverá influir decisivamente na construção de um direito internacional privado efetivamente condizente com as necessidades sociais.

$\mathrm{Na}$ segunda parte do trabalho de pesquisa, a tese volta-se para uma perquirição estritamente dogmática, com a tentativa de se construir uma resposta ao conflito de leis, versando sobre a lei aplicável à atribuição da guarda e suas conseqüências. Como salientou João Grandino Rodas, "freqüentemente, o tratamento jusprivatístico é olvidado, tanto pela doutrina quanto, até mesmo, pela jurisprudência. Essa abordagem ainda não usual, certamente, tornar-se-á imprescindível nesta quadra [relações familiares] em que a globalização passa a figurar como inelutável" ${ }^{\text {15 }}$. Em razão do estágio de desenvolvimento da matéria, tal abordagem será realizada de duas formas, e embasada em duas perspectivas. Em uma perspectiva meramente dogmática, a análise subdivide-se em dois modos de

\footnotetext{
${ }^{12}$ MARQUES, Cláudia Lima; CACHAPUZ, Maria Cláudia; VITORIA, Ana Paula da Silva. Igualdade entre filhos no direito brasileiro atual: direito pós-moderno? Revista dos Tribunais, São Paulo, v. 88, n. 764, p. 11-32, 1999, p. 17 informam que le retour des sentiments é uma das características da pós-modernidade. Marcado, de um lado, pela volta de certa "emocionalidade" no discurso jurídico, le retour des sentiments representa, ainda, a abertura para o imponderável, a procura por novos elementos sociais ou ideológicos que se encontram fora do sistema. E nesse sentido, o sistema passa "a incluir a argumentação e as decisões jurídicas, criando forte insegurança e imprevisibilidade quanto à solução a ser efetivamente encontrada".

${ }^{13}$ Sem que isso represente a ineficácia ou a inabilidade do direito internacional privado, pois, como afirma JAYME, Erik. O direito internacional privado e a família no umbral do século XXI. In: MARQUES, Claudia Lima; ARAUJO, Nadia de. O novo direito internacional: estudos em homenagem a Erik Jayme. Rio de Janeiro: Renovar, p. 21-28, 2005, p. 28, "No umbral do século XXI, a família mudou, porém, o direito internacional privado permanece sempre um instrumento eficaz e justo para indicar a lei aplicável aos casos multiconectados e multiculturais".

${ }^{14}$ Nesse sentido, confira-se DOLINGER, Jacob. A evolução do direito internacional privado no século XX. In: DIREITO, Carlos Alberto Menezes. Estudos em homenagem ao Prof. Caio Tácito. Rio de Janeiro: Renovar, p.335-348, 1997, p. 336 e 348.

15 RODAS, João Grandino. Prefácio. In: MONACO, Gustavo Ferraz de Campos. Direitos da criança e adoção internacional. São Paulo: RT, 2002, p. 12. Tal obra originou-se do trabalho de iniciação científica realizada pelo candidato com apoio financeiro da Fapesp (Fundação de Amparo à Pesquisa do Estado de São Paulo).
} 
demonstração dos resultados: a lei aplicável de acordo com o sistema jurídico brasileiro de origem meramente interna ${ }^{16}$ (capítulo III) e a lei aplicável conforme o sistema jurídico sugerido pela sociedade internacional, que faz aprovar uma série de textos convencionais a respeito da temática e de suas correlações (capítulo IV) ${ }^{17}$. O capítulo III é, por sua vez, subdividido conforme se trate de casos de manutenção dos membros da família em território nacional e casos de separação transfronteiriça dos membros da família ${ }^{18}$. Em seguida, um terceiro item procura abordar a alteração da situação fática, depois da atribuição da guarda e considerando as consequiências que ela gera em seu exercício, bem como no exercício dos direitos correlatos. Os dois primeiros capítulos desta segunda parte prescindem de uma análise jurisprudencial mais acurada. Reconhece-se que a tese seria enriquecida com tal abordagem. Todavia, o fato de se tratar de matéria que fica adstrita ao segredo de justiça tornou dificultoso o acesso às decisões judiciais. No mais das vezes, teve-se acesso a extratos de julgamento ou a ementas que pouco diziam a respeito do raciocínio seguido pela jurisprudência para se fixar os critérios de determinação da lei aplicável $^{19}$. Outras vezes, mesmo o acesso a tais ementas foi impossível em decorrência de uma visão absoluta do segredo de justiça que tornou inacessíveis os dados relativos, por

${ }^{16} \mathrm{O}$ tema não mereceu a devida atenção e sistematização da maior parte dos tratadistas brasileiros da matéria. Exemplifique-se, por ora, com a obra de STRENGER, Irineu. Direito internacional privado. 6. ed., São Paulo: LTr, 2005, cuja parte especial é das mais desenvolvidas.

${ }^{17}$ Não apenas tratados que tenham por objeto o conflito de leis ou outro dos possíveis objetos do direito internacional privado, mas, também, tratados sobre direitos humanos, porquanto aqueles exerçam, por vezes, importante tarefa complementar relativamente a esses últimos. No que respeita aos direitos das crianças, essa complementariedade não passou despercebida a PARRA-ARANGUREN, Gonzalo. La tarea complementaria de la Convención de las Naciones Unidas sobre los Derechos del Niño realizada por las Convenciones de la Conferencia de La Haya de Derecho Internacional Privado. Revista de la Facultad de Ciencias Jurídicas y Políticas, Caracas, n. 106, p. 51-67, 1998, nem a PFUND, Peter H. The Developing Jurisprudence of the Rights of the Child: Contributions of the Hague Conference on Private International Law. ILSA Journal of International and Comparative Law, v. 3, p. 665-675, 1997, p. 674. Também: DOLINGER, Jacob. A criança no direito internacional. São Paulo/Rio de Janeiro: Renovar, 2003; MONACO, Gustavo Ferraz de Campos. A proteção da criança no cenário internacional. Belo Horizonte: Del Rey, 2005.

${ }^{18}$ HAESBERT, Rogério. Migração e desterritorialização. In: PÓVOA NETO, Helión; FERREIRA, Ademir Pacelli (Org.). Cruzando fronteiras disciplinares: um panorama dos estudos migratórios. Rio de Janeiro: Revan - Faperj, p. 35-46, 2005, traça a evolução que retirou o migrante em geral da condição de desterritorializado levando-o para a condição de sujeito afeto à multiterritorialidade. A criança que assiste à separação internacional de seus pais apresentará, por vezes, o característico movimento pendular a que o autor chama mobilidade espacial e que empresta aos seus personagens a característica de poderem "reconfigurar sua identidade na própria idéia de movimento, tão valorizada na sociedade contemporânea". Veja-se, também, NASCIMBENE, Bruno. Il minore straniero e le norme sull'immigrazione. Rivista di Diritto Internazionale Privato e Processuale, Padova, v. 25, n. 4, p. 809-820, 1989.

19 E mesmo quando se teve acesso ao inteiro teor de algumas parcas decisões, por intervenção de Desembargadores do TJSP que solicitaram a pesquisa em meu nome, o material mostrou-se insatisfatório do ponto de vista do conflito de leis. 
exemplo, ao seqüestro internacional de $\operatorname{crianças~}^{20}$.

Por fim, uma segunda perspectiva é desenvolvida no capítulo V, no qual a tentativa é a de se comparar os ordenamentos de inspiração interna e internacional, demonstrando as conseqüências que a adoção do sistema sugerido pela sociedade internacional, por meio da ratificação dos tratados internacionais mencionados, poderá gerar no sistema interno brasileiro. Tal análise far-se-á por meio da busca daquilo que de diferente, de fluido, de especial houver nos sistemas analisados ${ }^{21}$, o que decorrerá, por certo, da análise empreendida nos capítulos precedentes do trabalho. Nesse sentido, trata-se de tese política a que se procura defender. Porém, cientificamente embasada e logicamente concatenada.

${ }^{20}$ Agradeço ao Professor Hermes Marcelo Huck a sugestão de contatar grandes escritórios de advocacia com atuação nessa matéria. Alguns poucos retornaram, fornecendo ementas de decisões. As sentenças ou acórdãos, em seu inteiro teor não foram fornecidas, no mais das vezes.

${ }^{21}$ A respeito, MARQUES, Cláudia Lima. Casos de divórcios japoneses no Brasil: introdução ao método de análise de casos. Revista da Faculdade de Direito da Universidade do Rio Grande do Sul, Porto Alegre, número especial, p. 150-156, set. 2002, p. 151. 
PARTE I

DIREITO INTERNACIONAL PRIVADO:

PROBLEMAS TEÓRICOS FUNDAMENTAIS RELACIONADOS

À GUARDA DE FILHOS 


\title{
A QUALIFICAÇÃO DA GUARDA COMO ANTECEDENTE PARA A APLICAÇÃO DO MÉTODO PRÓPRIO AO DIREITO INTERNACIONAL PRIVADO
}

\begin{abstract}
SUMÁRIO: 1. Qualificação da relação jurídica em direito internacional privado: 1.1. Relações familiares no direito brasileiro: introdução - 2. A atribuição da guarda: 2.1. A escolha do sistema de atribuição da guarda: 2.1.1. Guarda simples; 2.1.2. Guarda alternada; 2.1.3. Guarda compartilhada; 2.2. A escolha do guardião - 3. Conseqüências da atribuição da guarda: 3.1. Direito de visita; 3.2. Alimentos; 3.3. Administração dos bens de filhos menores - 4. Exercício do poder familiar na desunião das famílias.
\end{abstract}

\section{QUALIFICAÇÃO DA RELAÇÃO JURÍDICA EM DIREITO INTERNACIONAL PRIVADO}

Como se afirmou na Introdução, a correta qualificação da relação jurídica que apresenta pelo menos um elemento relacional alienígena é o pilar sobre o qual se assenta a aplicação do método próprio ao direito internacional privado, a fim de se resolver o conflito aparente de normas no espaço. Isso se faz pela busca do elemento de conexão indicado pelo legislador do foro, ainda que com a complementar atuação do órgão jurisdicional, que, eventualmente, poderá sopesar as condições materiais da relação jurídica com a intenção de fazer incidir o elemento de conexão que demonstrar possuir maiores ligações com a relação fática que se esteja a analisar.

Nesse sentido, a qualificação da relação jurídica apresenta-se como um prius à aplicação do método próprio ao direito internacional privado, seja esse o método que for, conformado por critérios fechados ou abertos. É que, muito embora hoje se admita a variedade de métodos, alguns ligados ainda ao viés estritamente normativista e outros 
abertos já à possibilidade de se levar em consideração as normas materiais eventualmente aplicáveis, com o escopo de realizar maior justiça, fato é que a qualificação continua a se apresentar como antecedente à busca do elemento de conexão, posto demandar, por exemplo, a interpretação da norma de conflito de leis ${ }^{22}$.

Entretanto, deve-se ter em mente que o modo de se operar a qualificação estará impregnado pelas características metodológicas que o sistema do foro competente adotar. Assim, colocar-se-á em relevo a classificação determinada pela lei do foro (lex fori), pela lei material afinal aplicável (lex causae) - em verdade, lei que se mostra à primeira vista aplicável -, ou, ainda, pela comparação entre os vários sistemas jurídicos potencialmente aplicáveis a fim de se buscar um denominador comum entre todos que possibilite qualificação satisfatória à luz dos mesmos, dependendo a escolha de tal procedimento, muitas vezes, da estrutura metodológica assente no país para a resolução dos conflitos. $\mathrm{O}$ objetivo desse item, assim, é o de dar notícia das várias escolas classificatórias desenvolvidas nos estertores do século XIX e durante todo o século XX, culminando pela indicação do sistema que vigora do Brasil. Em seguida, o capítulo desenvolve-se com a descrição dos caracteres jurídicos que conformam o instituto da guarda e dos institutos que podem ser considerados como sua conseqüência, situando-se o objeto do estudo.

A razão teórica para se proceder à qualificação assenta-se na premissa segundo a qual os fatos naturais não apresentam qualquer conotação apriorística no plano jurídico, necessitando, por isso, de uma narrativa minuciosa a respeito de sua conformação, para que se possa decidir se a narração elaborada oferece contato com o sistema jurídico ${ }^{23}$. Até que se encontre a juridicidade da narrativa, esta permanecerá atinente apenas ao plano fático, passando ao mundo jurídico tão-só quando sua conformação se mostrar adequada a algum conceito jurídico determinado ${ }^{24}$. É que apenas os fatos considerados pela sociedade como juridicamente relevantes são por ela regulados com base nos caracteres gerais do sistema jurídico, a saber, sociabilidade, imperatividade e coercibilidade. Ausente um desses caracteres, o fato poderá amoldar-se a outros sistemas de regulação social que não o

${ }^{22}$ MARQUES DOS SANTOS, António. Breves considerações sobre a adaptação em direito internacional privado. In: Estudos de direito internacional privado e de direito processual civil internacional. Coimbra: Almedina, 1998, p. 65.

${ }^{23}$ CASTRO, Amilcar de. Direito internacional privado. 5. ed. atualizada por ROCHA, Osíris. Rio de Janeiro: Forense, 1997, p. 222-223.

24 "Para enquadrar o fato na norma, há que se ter claramente delineado aquele e bem entendida esta. $\mathrm{O}$ fato $\mathrm{e}$ a norma, a vida e a lei. Ambos exigem classificação ou caracterização, enfim, qualificação". DOLINGER, Jacob. Direito internacional privado: parte geral. 8. ed. São Paulo/Rio de Janeiro: Renovar, 2005, p. 364. 
direito, mas carecerá de acomodação na seara jurídica.

A recondução dos fatos a uma dada categoria jurídica consiste justamente na tentativa de classificá-los juridicamente, demonstrando-se sua adequação estrutural ao esboço abstrato que o legislador desenha para determinar a proteção jurídica do bem - também ele jurídico - que se visa resguardar.

No âmbito do direito internacional privado, o problema da qualificação da situação fática se põe de duas perspectivas coligadas e que se relacionam com a estrutura da norma de conflitos, de um lado, e com o próprio conflito de leis no espaço, de outro ${ }^{25}$.

No que concerne à estrutura das normas de conflito, é sabido que elas são estilizadas pelo legislador segundo um acurado sistema de remissões, cujo objeto principal são as situações da vida ou, ao menos, aspectos de situações da vida transnacional ${ }^{26}$. As remissões estabelecidas pelo legislador têm por origem os grandes grupos classificatórios das relações juridicamente relevantes, e a parte remissiva da norma se estrutura por meio da opção legislativa por um ou por mais de um elemento de conexão. Assim, desse prisma, o problema da qualificação refere-se ao enquadramento teórico dos fatos juridicamente apreciados em um dos grupos estabelecidos nas normas de direito internacional privado.

Nesse sentido, qualificar a relação jurídica é pesquisar a respeito de sua pertinência teórica a um ou a outro dos grupos relacionais estruturados pelo legislador. Percebe-se, por isso, que a questão está intimamente ligada ao rol das fontes do direito internacional privado, porquanto seja de se esperar que, quanto maior a especialização impressa no sistema pelo legislador, maior será a dificuldade de enquadramento da questão. Com efeito, um sistema normativo como o brasileiro, que se compõe de pouco mais de uma dezena de normas remissivas ou indiretas, acaba por revelar uma opção extremamente genérica por parte do legislador, o que facilita a classificação da relação jurídica em uma das categorias reconhecidas como paradigmáticas. No entanto, um sistema como o que fora estabelecido no Esboço das Leis Civis por Teixeira de Freitas ${ }^{27}$, com uma multiplicidade

25 Da natureza dos conceitos jurídicos, do fato de "serem eles conceitos técnico-jurídicos e não puros conceitos descritivos nascem delicados problemas, pertencentes uns à teoria da interpretação da norma de conflitos, atinentes outros ao momento de sua aplicação. São eles que no seu conjunto constituem a famosissima quaestio da qualificação em direito internacional privado”. FERRER CORREIA, António. Lições de direito internacional privado I. Coimbra: Almedina, 2000, p. 200.

${ }^{26}$ PINHEIRO. Direito..., cit., v. 1, p. 392.

27 Adotado, afinal, sem alterações de monta na Argentina e, ao que parece, utilizado como paradigma em normas de direito internacional privado estatuídas ao longo do século XX, com especializações das regras 
de normas de conflito disseminadas pelo regramento material, indicando-se o elemento de conexão eleito para cada instituto jurídico regulado, dificulta o trabalho do intérprete se se atentar para o fato de que a norma de direito internacional privado não traz, explicitamente, uma "conceituação legal daquelas categorias genéricas contidas nos textos de DIP"28, forçando-o a buscar o conteúdo de tais categorias genéricas em outras fontes. Na hipótese do Esboço, a proximidade local das normas materiais e conflituais levaria o intérprete, com maior facilidade, a recorrer ao conceito estabelecido na lei do foro, em detrimento de outras possibilidades que lhe são abertas, como a lex causae e o eventual recurso ao direito comparado, "antítese à clausura nacionalista ocorrida após o advento das codificações", como salienta Marilda Rosado de Sá Ribeiro ${ }^{29}$.

Nessa esteira de pensamento, Valladão afirma que o aproveitamento de conceitos próprios a determinados ramos jurídicos, fazendo-os incidir, sem crítica, no ramo que os toma de empréstimo, está sujeito à submissão que, por muito tempo, vigorou para o direito público, que se via impelido a recorrer ao direito privado. Aplaudindo a nova visão doutrinária, relativa à autonomia dos respectivos conceitos, e fiel à convicção de constituir o direito internacional privado um sobredireito, afirma o autor:

"Quando em um texto constitucional ou de DIP se usa uma expressão jurídica genérica, a sua definição não pode ser a que lhe dão textos outros, respectivamente, de leis ordinárias ou de leis civis, pois destarte a norma básica ou a de conflitos veria cortados os seus horizontes, desnaturada a sua finalidade e, praticamente, se esvaziaria, ficaria dependendo de outra norma de categoria inferior ou diversa que a alteraria à vontade.

(...)

E a norma de DIP enunciada para reger relação conectada com leis espacialmente em divergência, para optar entre a lei do foro e qualquer outra estrangeira ou mesmo apenas estranha (...) têm perspectivas mais largas do que o direito do foro, do que o seu próprio direito material. Considera o problema jurídico do ponto de vista extranacional, encarando as diversas leis do mundo e harmonizando-as (...) para

de conflito. Cf. VALLADÃO, Haroldo. Direito internacional privado. 2. ed. Rio de Janeiro: Freitas Bastos, 1970 , p. 255.

${ }^{28}$ VALLADÃO. Direito..., cit., p. 256.

${ }^{29}$ Na esteira de San Tiago Dantas e Jacob Dolinger. Cf. RIBEIRO, Marilda Rosado de Sá. Importância do direito comparado. In: TIBURCIO, Carmen; BARROSO, Luís Roberto (Org.). O Direito Internacional contemporâneo. Estudo em homenagem ao Professor Jacob Dolinger. Rio de Janeiro: Renovar, p. 679-692, 2006, p. 681. 
assegurar a continuidade espacial da vida jurídica das pessoas (...).

Possui, destarte, a norma de DIP os seus conceitos próprios, autônomos, com essa marca indestrutível de universalidade que os distingue dos adotados nas normas de direito civil do foro, marca que constitui a base de sua formação, caracteriza a sua personalidade frente aos outros ramos do direito e será o norte para sua interpretação, para os problemas de qualificação" ${ }^{30}$.

Parece que Valladão insurge-se contra a qualificação baseada na lex fori, por entender que essa forma de enquadramento da relação fática em uma categoria jurídica vigente no foro poderá não encontrar respaldo na lei material que, afinal, deverá ser aplicada.

A questão esbarra, portanto, no próprio conflito de leis no espaço e na possibilidade de que as leis em conflito aparente para a resolução da quaestio juris estejam a emprestar aos mesmos fatos distintas qualificações. Assim, se dois ou mais ordenamentos jurídicos reivindicam a sua aplicação para a resolução da lide, surge a questão de saber como deve o juiz proceder com a finalidade de encontrar a correta classificação para a relação fática, ou seja, se deve ele procurar enquadrar os fatos narrados em categoria jurídica determinada pela lei do foro ou se deve, ao contrário, procurar o correto enquadramento segundo as determinações da lei material que, em princípio, parece ser a aplicável ${ }^{31}$.

O problema dos critérios a serem seguidos para se proceder à correta qualificação não foi notado na doutrina senão após o estabelecimento de discussões a respeito na jurisprudência. Os casos da sucessão do maltês na Argélia, do testamento hológrafo do holandês formalizado na França e do casamento civil, em jurisdição francesa, de cidadão grego e cidadã francesa ${ }^{32}$ levantaram a questão, já que, segundo a qualificação admissível em cada um dos ordenamentos jurídicos envolvidos, chegar-se-ia a soluções diversas.

\footnotetext{
${ }^{30}$ VALLADÃO. Direito..., cit., p. 256 - procedeu-se à adequação das regras de acentuação hoje vigentes. O destaque encontra-se no original compulsado. No mesmo sentido, FERRER CORREIA. Lições..., cit., p. 205, afirma que, "pertencendo a norma de conflitos à lex fori, a esta lei tem de pertencer também a sua interpretação. Só que por lex fori não podemos nós entender aqui a lex materialis, senão a lex formalis, o direito internacional privado dessa lei. Como já foi dito, seria erro grave supor que o conteúdo e limites dos conceitos próprios do direito de conflitos se obtêm necessariamente e apenas por via de uma simples referência aos conceitos homólogos do respectivo sistema de preceitos materiais". Saliente-se, todavia, que o caso português é típico na medida em que assentadas as múltiplas normas de direito internacional privado na doutrina defendida pelo autor. No mesmo sentido: PINHEIRO. Direito..., cit., v. 1, p. 401-402.

31 "Natural a perplexidade do juiz diante das incertezas conceituais da mesma relação jurídica. É um fenômeno que não podemos desmentir, e de valor, porque a eleição do critério da qualificação pode estabelecer decisões diametralmente opostas". TENÓRIO, Oscar. Direito internacional privado. 11. ed. Rio de Janeiro: Freitas Bastos, 1976, v. 1, p. 295.

${ }^{32}$ BARTIN, Etienne-Adolphe. La doctrine des qualifications et ses rapports avec le caractère national des règles du conflit des lois. Recueil des Cours, Paris, v. 31, 1930, p. 562-621. Entre nós: DOLINGER. Direito..., cit., p. 366-367.
} 
No que diz respeito a essa dificuldade de se buscar a forma mais adequada de qualificar a relação fática para a qual se busca uma solução jurídica, a todas as teorias que se desenvolveram foram endereçadas críticas mais ou menos veementes.

Da tentativa de se deixar assentada a necessidade de qualificação segundo a lex fori, ${ }^{33}$ afirma-se ser ela melhor por estar o juiz do foro acostumado ao sistema classificatório vigente em seu país. Ademais, como a regra de conflitos a ser utilizada é aquela que se esculpiu no bojo desse mesmo sistema, é natural pressupor que os conceitos são em si assemelhados e buscam atingir senão o mesmo escopo, ao menos escopo social extremamente aproximado. No entanto, segundo alguns autores, essa forma de iniciar a resolução do conflito de leis acarreta a impossibilidade e a incapacidade de se aplicar, muitas vezes, a lei mais próxima à relação jurídica. Ademais, utilizar um critério classificatório para, em seguida, aplicar a lei de outro ordenamento pode ocasionar a aplicação de uma lei que não se mostra a mais adequada na medida em que, no ordenamento a ser aplicado, a mesma relação receberia outra conformação jurídica ${ }^{34}$. Partem esses autores da conviç̧ão de que "uma lei nunca é convocada na totalidade das suas regras materiais, mas a norma de conflitos da lex fori recorta no sistema a que se refere um sector determinado e localiza nele a competência atribuída a esse mesmo sistema" ${ }^{35}$. Assim, percebe-se que a visão proposta faz coincidir a qualificação pela lex fori e a qualificação das regras do direito estrangeiro que podem ser aplicadas para a resolução do litígio. Desse modo, sendo diversa a natureza do instituto envolvido em ambos os sistemas, o juiz do foro restaria sem norma a aplicar, já que, nas normas de mesma qualificação do direito estrangeiro que foram convocadas pelo direito internacional privado do foro, não haveria nenhuma disposição pertinente ao caso em questão, sendo preferível, então, qualificar segundo os desígnios da lex causae.

Já ao sistema de qualificação pela lex causae $e^{36}$ costuma-se indicar como empecilho

\footnotetext{
${ }^{33}$ BARTIN. La doctrine..., cit.

34 “A caracterização lege fori (...) é contrária à ideia de paridade de tratamento entre a lei [do] foro e a lei estrangeira. Com efeito, se determinarmos a relevância da situação segundo o Direito material do foro e, nesta base, designarmos uma lei estrangeira como competente, podemos ser levados a aplicar, por força de uma norma de conflitos, normas materiais estrangeiras que não correspondem à categoria normativa utilizada na previsão da norma de conflitos. Isto contraria a justiça da conexão e a ideia de adequação que lhe está ínsita. O nexo de adequação entre o objecto e a estatuição da norma não seria respeitado". PINHEIRO. Direito..., cit., v. 1, p. 401.

${ }^{35}$ FERRER CORREIA. Lições..., cit., p. 209.

${ }^{36}$ Doutrina preferida por Despagnet, na França, Pacchioni, na Itália, e Wolff, na Alemanha. Entre nós, Haroldo Valladão. Cf. DOLINGER. Direito..., cit., p. 369 e RODAS, João Grandino. Direito internacional privado brasileiro. São Paulo: RT, 1993, p. 71.
} 
principal a impossibilidade de se saber, de antemão, qual será efetivamente a lei material aplicável, já que ela dependerá justamente da qualificação que se estabelecer segundo a lei estrangeira e seu enquadramento na respectiva norma de direito internacional privado do foro, o que pode causar dificuldades de monta, pois, não raras vezes, a qualificação feita pela lei alienígena poderá forçar ao enquadramento da hipótese fática em uma norma de direito internacional privado do foro que indicará, por sua vez, a aplicação da própria lei material indígena ou de terceira lei, também estrangeira, modificando a idéia preliminar de que a lei usada para a qualificação da questão seria a lei aplicável. E isso porque, corriqueiramente, o juiz será levado à suposta lex causae por meio de sua própria lei conflitual, escolhendo-a com base na sua própria qualificação da questão - com base, portanto, na lex fori. Cria-se, assim, a possibilidade de que se estabeleça um círculo vicioso $^{37}$, na medida em que a requalificação da questão, segundo agora os desígnios do direito alienígena ou indígena que a busca anterior tiver demonstrado como aplicáveis, poderá indicar outro ordenamento como o competente para fazer valer as suas normas materiais.

Para evitar o estabelecimento desse suposto e provável círculo vicioso, sugere Ernst Rabel o recurso a mecanismos próprios do direito comparado para se buscar conceitos que possam apresentar notas de autonomia e universalidade capazes de, em médio prazo, fazer desaparecer os conflitos de qualificação. Todavia, justamente por se assentar em conflitos que dificultam a qualificação, é de se esperar que seja extremamente dificultada a busca de caracteres autônomos e universais capazes de dirimir tais conflitos, já que, nesses casos, seriam os mesmos conflitos meramente aparentes ${ }^{38}$. Ademais, como ressalta Magalhães Collaço, o método comparativo está longe de ser uma solução para o problema, sendo preferível encará-lo, como o faz agora o sistema de qualificação português, como um instrumento ${ }^{39}$.

No que concerne ao direito internacional privado brasileiro, é de se notar que o legislador de 1942 fez duas esparsas referências à lei a que se deve recorrer para fins de qualificação, mencionando a necessidade de se valer da lex causae sempre que se tratar de

\footnotetext{
37 À pergunta a respeito de haver ou não um círculo vicioso nessa busca classificatória por meio da lex causae, responde PINHEIRO. Direito..., cit., v. 1, p. 402-403, que não, afirmando que o procedimento leva em conta um raciocínio hipotético que deve ter em vista "cada uma das ordens jurídicas potencialmente aplicáveis", incluindo-se a lex fori, se esta for uma potencial lex causae, o que sucede freqüentemente.

${ }^{38}$ DOLINGER. Direito..., cit., p. 370-371; FERRER CORREIA. Lições..., cit., p. 202-203.

${ }^{39}$ MAGALHÃES COLLAÇO, Isabel Maria de. Da qualificação em direito internacional privado. Lisboa: s/e, 1964, p. 174 et seq.
} 
qualificar os bens (lei do local da situação dos bens) e as obrigações (lei do local da constituição). Silenciou, todavia, quanto ao estabelecimento de uma regra geral. Nesse sentido, a maioria da doutrina invoca o art. $6^{\circ}$ do Código Bustamante, que é explícito ao estatuir a qualificação pela lex fori. No mesmo sentido o Projeto de Lei do Senado 269, de 2004, de autoria do senador Pedro Simon ${ }^{40}$, que dispõe:

Art. 17. Qualificação - A qualificação destinada à determinação da lei aplicável será feita de acordo com a lei brasileira.

Percebe-se claramente que o sistema brasileiro de direito internacional privado prefere a qualificação de acordo com a lex fori. Assim, no que concerne ao desenvolvimento do presente trabalho, procurar-se-á demonstrar como as relações fáticas que ensejam o pedido de atribuição da guarda de filhos, desencadeando suas conseqüências mais comuns, são reguladas pelo ordenamento nacional, já que a perquirição que se fará posteriormente, ao longo da segunda parte do trabalho, terá sempre em vista o direito internacional privado brasileiro vigente e o direito internacional privado convencional ${ }^{41}$ a que o Brasil tenha emprestado assentimento, bem como aquele que se encontra aberto à participação do Estado brasileiro, participação, todavia, ainda não efetivada.

\subsection{Relações familiares no direito brasileiro: introdução ${ }^{42}$}

As famílias se formam normalmente, mas nunca exclusivamente, pela união de duas

\footnotetext{
${ }^{40}$ Saliente-se que o projeto apresentado pelo senador gaúcho é uma atualização do Projeto de Lei 4.905, de 1995, do Poder Executivo, aos ditames do Código Civil. O anteprojeto foi elaborado por Comissão presidida pelo professor João Grandino Rodas e composta pelos professores Jacob Dolinger, Rubens Limongi França e Inocêncio Mártires Coelho.

41 "No que toca às normas de conflito de fonte supraestadual, maxime convencional, a interpretação dos conceitos utilizados na sua previsão (...) tem de ser autônoma relativamente às ordens jurídicas nacionais e assentar numa comparação de direitos.” PINHEIRO. Direito..., cit., v. 1, p. 400. Isso se deve ao fato de tais convenções internacionais buscarem promover a unificação das regras do direito de conflitos de todos os Estados-membros relativamente à matéria de que tratam, o que só pode ser alcançado com base na interpretação extranacional. Também: DOLINGER. Direito..., cit., p. 383-384, ao analisar uma série de disposições específicas a algumas convenções internacionais de direito internacional privado, mormente assinadas no seio da Conferência da Haia de Direito Internacional Privado ou no âmbito das Conferências Interamericanas especializadas de Direito Internacional Privado (CIDIPs).

${ }^{42}$ Uma versão preliminar - e por isso bastante incompleta - da pesquisa relativa a este capítulo (itens 1.1. até 2.2.) foi publicada pelo autor em MONACO, Gustavo Ferraz de Campos. Atribuição da guarda na desunião dos pais: reconstrução do instituto a partir da figura primária de referência. In: DELGADO, Mário; FIGUEIREDO, Jones. Questões controvertidas no novo Código Civil. São Paulo: Método, 2005, v. 3, p. 105-128. O artigo emprestou estrutura aos atuais tópicos, mas a pesquisa encontra-se, agora, atualizada e ampliada.
} 
pessoas $^{43}$ que buscam, irmanadas, perseguir o seu desenvolvimento individual, por meio do reconhecimento da entidade familiar que acabam de constituir como aquele espaço privilegiado no qual o suprimento de suas necessidades pessoais pode dar-se de forma mais vantajosa $^{44}$. Trata-se, assim, do espaço em que os projetos e sonhos comuns podem realizar-se mais facilmente ${ }^{45}$, fazendo da família um instrumento, pelo que passa a se apresentar, antes de tudo, como uma família funcional ${ }^{46}$. Daí por que se afirme que o casamento aproxima-se, hoje, "mais de uma parceria sentimental do que [de] uma instituição impessoal estabelecida pela autoridade marital" ${ }^{17}$, como fora no passado.

Segundo o posicionamento doutrinário mais recente em direito de família, o grupo familiar deve apresentar-se com notas de afetividade, ostensividade e estabilidade $^{48}$. A afetividade se expressa no amor devotado pelos indivíduos que compõem o grupo familiar uns em relação aos outros ${ }^{49}$, amor esse que a Declaração Universal dos Direitos da Criança

${ }^{43}$ Normalmente, mas nunca exclusivamente, porquanto não se deva olvidar a possibilidade de constituição das famílias monoparentais. Todavia, nesse caso, não se há falar em atribuição da guarda de filhos, muito embora seja possível a atribuição da guarda do parente incapaz a outro membro da família que não o genitor.

44 "Os cônjuges se unem por supostos comuns, quase sempre inconscientes, com a expectativa de serem libertados dos seus conflitos pelo parceiro. (...). O espaço interno do casal (...) nasce do encontro entre os mundos interno e externo dos parceiros.” FÉRES-CARNEIRO, Terezinha; MAGALHÃES, Andrea Seixas. Conjugalidade dos pais e projeto dos filhos frente ao laço conjugal. In: FÉRES-CARNEIRO, Terezinha (Org.). Família e casal: efeitos da contemporaneidade. Rio de Janeiro: PUC-Rio, 2005, p. 111-121, p. 113.

${ }^{45}$ GLANZ, Semy. A família mutante: sociologia e direito comparado. Rio de Janeiro: Renovar, 2005, p. 25, chega a falar em família teto-comum.

${ }^{46} \mathrm{O}$ caráter funcionalista da família não é nenhuma novidade. Como ressalta LEITE DE CAMPOS, Diogo. Lições de direito da família e das sucessões. 2. ed. Coimbra: Almedina, 2005, p. 139-140, “os direitos familiares (pessoais) não são direitos subjectivos no sentido estrito, ou seja, direitos de exigir de outrem um certo comportamento no interesse do credor. São, antes, poderes-deveres, poderes funcionais. O titular do poder não o exerce no seu interesse mas, antes, ('também') no interesse do «sujeito passivo». (...). a mudança mais significativa traduziu-se no titular do interesse. O titular do interesse era a família, grupo coeso, hierarquicamente organizado que se considerava titular de interesses específicos (...). Hoje, com o abandono de importantes funções da família, sobretudo da sua função de produção económica, e com a perda de parte do seu significado como veículo de transmissão dos bens e do estatuto social, os membros da família libertaram-se dos «interesses» desta, passando a prosseguir ( sic) 'livremente' os seus interesses pessoais".

${ }^{47}$ DELINSKI, Julie Cristine. O novo direito da filiação. São Paulo: Dialética, 1997, p. 18.

${ }^{48}$ LÔBO, Paulo Luiz Netto. Entidades familiares constitucionalizadas: para além do numerus clausus. Revista Brasileira de Direito de Família, Porto Alegre, n. 12, p. 40-55, 2002.

${ }^{49}$ Os gregos conheceram três vocábulos capazes de traduzir a idéia do amor. Eros, philia e agape. Philia designa o amor de amizade e por isso mesmo não serve para se referir à constituição de um grupamento familiar. Para a constituição de uma família é necessária a influência de eros, sem que deixe de se fazer presente a agape. A família formada por um homem e uma mulher, que deixam os seus grupos familiares primitivos para constituir uma nova unidade social é uma família que deve basear-se em eros, enquanto forma de amor "ascendente, ambicioso e possessivo", um amor que se baseia na retirada do ser humano do seu grupo para a formação de um novo grupo. Mas o eros, sozinho, se pode ser a mola propulsora da formação da família, não traduz, ainda, a idéia de afeto enquanto amor devotado, amor "descendente, oblativo, ou seja, a agape", o "amor que se torna, verdadeiramente, descoberta do outro, superando, assim, o caráter egoísta que antes, claramente, prevalecia. (...). Na realidade, eros e agape - amor ascendente e amor descendente - nunca se deixam separar completamente um do outro. Quanto mais os dois 
reconhece, de forma pioneira, como nota característica da família funcional, instrumental, eudemonista $^{50}$. A ostensividade, por sua vez, manifesta-se pela vivência pública entre os membros da família que se tratam como parentes e, demonstrando ou não seu afeto publicamente, são aceitos no grupo social em que convivem, como entidade familiar que formam. A estabilidade, por sua vez, não se manifesta por um termo prefixado (muito embora a lei possa - mas não deva - fixá-lo), mas, sim, pela continuidade ${ }^{51}$ na experimentação de sua afetividade e de sua ostensividade.

Pode-se dizer, então, que duas pessoas se destacam de suas unidades familiais originárias para, unidas, construir um novo grupamento familiar, no qual haverá a transformação de suas personalidades individuais sem que isso represente a perda de suas individualidades e de suas condições de sujeitos de direitos ${ }^{52}$. E é nesse ambiente que será possível acolher novos indivíduos, aceitos no grupo social na função de filhos ${ }^{53}$, a fim de

encontrarem a justa unidade, embora em distintas dimensões, na única realidade do amor, tanto mais se realiza a verdadeira natureza do amor em geral. Embora o eros seja, inicialmente, sobretudo ambicioso, ascendente - fascinação pela grande promessa de felicidade -, depois, à medida que se aproxima do outro, far-se-á cada vez menos perguntas sobre si próprio, procurará sempre mais a felicidade do outro, preocupar-se-á cada vez mais com ele, doar-se-á e desejará 'existir para' o outro. Assim se insere nele o momento da agape; caso contrário, o eros decai e perde mesmo a sua própria natureza". BENTO XVI, Papa. Deus caritas est - Carta encíclica sobre o amor cristão. (sem indicação do tradutor). São Paulo: Paulinas, 2006, p. 16-17. Segundo DOLINGER, Jacob. O direito e o amor. Revista da Faculdade de Direito da Universidade do Estado do Rio de Janeiro, Rio de Janeiro, n. 2, p. 233-245, 1994, p. 236, o amor "singular/singular - o amor que une homem e mulher - será quiçá o único que pode capacitar o ser humano a elevar-se às alturas de amar o Divino". Acredita o autor que seja esta a explicação para a inclusão do Cântico dos Cânticos, "o romântico e erótico poema composto pelo Rei Salomão" na Bíblia Sagrada.

50 A respeito, em uma perspectiva psicológica: ROUDINESCO, Elisabeth. A família em desordem [La famille en desórdre]. Tradução de André Telles. Rio de Janeiro: Jorge Zahar, 2003.

${ }^{51}$ Continuidade, aqui, não se refere absolutamente à perpetuidade, posto que admissível o desfazimento do vínculo matrimonial em estágio posterior ou concomitante à dissolução da sociedade conjugal, bem assim a dissolução de união estável.

${ }^{52}$ MARQUES; CACHAPUZ; VITORIA. Igualdade..., cit., p. 17.

${ }^{53} \mathrm{Na}$ estrutura familiar, segundo Lacan, cada um dos genitores desempenha uma função e as relações de cada uma dessas funções com a criança são capazes de desempenhar em sua estrutura psíquica um sintoma diverso. O sintoma seria "um modo de resposta que se impõe para a criança sobre a verdade do casal parental ou sobre a subjetividade da mãe". Cf. DUARTE, Lenita Pacheco Lemos. A guarda dos filhos na família em litígio: uma interlocução da psicanálise com o direito. Rio de Janeiro: Lumen Juris, 2006, p. 139. Segundo BAUMAN, Zygmunt. Amor líquido: sobre a fragilidade dos laços humanos [Liquid love (on the frailty of human bonds)]. Tradução de Carlos Alberto Medeiros. Rio de Janeiro: Jorge Zahar, 2004, p. 59, "esta é uma época em que um filho é, acima de tudo, um objeto de consumo emocional". E quando os sonhos parecem frustrar-se, pelo aparecimento dos sintomas da criança, a demanda do casal é pela reconstrução afetiva da criança, muitas vezes sem perceber a individualidade desta nem o fato de que o problema, no mais das vezes, está no relacionamento conjugal. "Desde 1998 até o momento [2003], de um total de 34 casos atendidos apenas quatro chegaram à clínica com um pedido explícito para terapia de casal, ou seja, só dez por cento das famílias assistidas pensaram nessa possibilidade; em todas as demais, a queixa continuava nos filhos". Cf. GOMES, Isabel Cristina. Alcances e limites da psicoterapia analítica com casais e famílias. In. FÉRES-CARNEIRO, Terezinha (Org.). Família e casal: arranjos e demandas contemporâneas. Rio de Janeiro: PUC-Rio; São Paulo: Loyola, p. 215-224, 2003, p. 219. 
se ampliar o grupo familiar formado pela união de homem e mulher ${ }^{54}$. Bem por isso, a dinâmica familiar não se esgota na constituição desse novo espaço privilegiado. É necessário que esse grupo recém-criado se mantenha, transforme-se, transmude-se diuturnamente como forma de conseguir equilibrar as forças e as vocações individuais que certamente enfrentarão momentos de tensão e desgaste, equacionando as diversas maneiras de se encarar a vida e os problemas que surgem da convivência, além de permitir o próprio desenvolvimento individual, que poderá desembocar, em algum momento da vida em comum, na necessidade de se encarar a ampliação do grupamento familiar pela chegada de um filho, assumindo-se, em conseqüência, todas as responsabilidades daí advindas, entre as quais se encerra a atribuição do poder familiar ${ }^{55}$.

Afirma-se, com freqüência, que normalmente as famílias nucleares surgem da união de esforços comuns por parte de duas pessoas que decidem, juntas, constituir esse núcleo. Assim, a intencionalidade de constituição dessa família é elemento essencial para sua configuração como grupamento familiar. Se faltar a intenção, não será família o que se constitui por essa via, como é o caso de dois amigos de sexo opostos que vivem juntos, repartindo as despesas, as ilusões e as conquistas de suas vidas, ou mesmo o caso de dois namorados que vivem juntos, porém sem a intenção de constituir uma família.

No entanto, não é apenas pela união de duas pessoas que a família pode formar-se. Grupos familiares há em que a conformação não dependeu da intencionalidade concorrente de dois indivíduos. Assim ocorre com aquelas pessoas que, unilateralmente e sozinhas, assumem uma prole em decorrência de gravidez indesejada ou, ainda que inconscientemente desejada, fruto de uma relação íntima passageira. Da mesma forma essa prole pode ser unilateralmente assumida por meio de adoção singular. Nessas hipóteses, a intenção de formar família (convivendo com a gravidez ou adotando singularmente uma criança qualquer) está presente, mas há que se proceder a uma necessária diferenciação

\footnotetext{
${ }^{54}$ Sem adentrar aqui na polêmica a respeito da possibilidade de constituição de família homossexual ou homoafetiva, portanto.

${ }^{55} \mathrm{O}$ termo poder familiar vem substituir a antiga expressão pátrio poder. Se, de um lado, representa um avanço significativo por encerrar em si o reconhecimento da igualdade de poderes e deveres entre os membros do casal, por outro, continua indicando uma supervalorização dos poderes atribuídos aos pais, em detrimento das responsabilidades que estes devem assumir quando lhes advém prole. Nesse sentido, parecem mais acertadas as expressões responsabilidade parental ou responsabilidade familiar. Cf. MONACO, Gustavo Ferraz de Campos; CAMPOS, Maria Luiza Ferraz de. O direito de audição de crianças e jovens em processo de regulação do exercício do poder familiar. Infância e Juventude, Lisboa, n. 1, p. 925, 2006. A respeito do pátrio poder no direito romano, veja-se LÁZZARO, Héctor Eduardo. La patria potestad en el derecho romano. In: LÓPEZ-ROSA, Ramón; PINO-TOSCANO, Ramón (Org.). El derecho de familia: de Roma al derecho actual. Huelva: Universidad de Huelva, p. 373-390, 2004.
} 
entre tais hipóteses e aquela primeiramente mencionada, porquanto naquela a intenção é concomitante com a intenção de outro sujeito de direito, ao passo que nestas é singular, individual e independente da vontade de outrem.

Quanto às famílias constituídas por vontades concomitantes, abre-se a possibilidade de que sua formação prescinda das formalidades legais, aperfeiçoando-se com a simples vivência pública, contínua e duradoura de pessoas de sexos diferentes, vivência que deve ser qualificada pela intencionalidade de configuração da entidade familiar. Todavia, se a vontade das pessoas envolvidas existir no sentido de proceder à constituição da família por meio do casamento, a conformação do núcleo familiar dependerá ainda da observância das formalidades legais aptas a configurar entre elas o vínculo matrimonial, que falta nas hipóteses das famílias convivenciais.

Contrapõem-se, então, as famílias matrimoniais, com vontade concorde expressamente declarada em ato solene; as convivenciais, com vontade concorde presumida ou expressamente declarada (faltando ou havendo contrato de convivência) e as monoparentais, em que a vontade, como se disse, é unilateral. No entanto, pode bem ser que as famílias matrimoniais e as convivenciais, originalmente biparentais, venham a se tornar famílias monoparentais em função da morte ou do desaparecimento de um dos genitores da prole. Nessas hipóteses limítrofes, nada há a fazer, uma vez que o genitor sobrevivente ou remanescente permanecerá, sem oposição de qualquer espécie, no exercício do poder familiar, a menos que um terceiro, estranho à relação familiar em sentido estrito, venha a solicitar a guarda da prole, comprovando que o genitor remanescente mantinha conduta incompatível com a qualidade de pai ou de mãe ${ }^{56}$.

Hipótese diversa, no entanto, é aquela em que os genitores da prole tenham decidido, por livre e espontânea vontade ou por impossibilidade de manutenção da vida em comum, desfazer a relação conjugal ou convivencial até então existente ${ }^{57}$, porque essa convivência e os apoios recíprocos prestados no seio familiar já não satisfazem plenamente as

\footnotetext{
${ }^{56}$ MALHEIROS FILHO, Fernando. Os princípios e a casuística na guarda dos filhos. Revista de Direito Privado, São Paulo, ano 3, v. 10, p. 107-127, 2002 traz à colação a prática jurisprudencial segundo a qual o pai viúvo, durante a viuvez, e a mãe amancebada após a viuvez deveriam ser preteridos da guarda de seus filhos em favor dos avós, por exemplo.

${ }^{57}$ JABLONSKI, Bernardo. Afinal, o que quer um casal? In: FÉRES-CARNEIRO, Terezinha (org.). Família e casal: arranjos e demandas contemporâneas. Rio de Janeiro: PUC-Rio; São Paulo: Loyola, 2003, p. 161, afirma que as principais razões invocadas pelos casais infelizes para não requererem a separação ou o divórcio são o sentimento de culpa (predominante nos homens) e a falta de coragem e o medo de futuros problemas financeiros (predominantes nas mulheres).
} 
aspirações individuais dos membros da família ${ }^{58}$, tornando impossível a realização conjunta de planos e sonhos comungados e a manutenção da vida em comum ${ }^{59}$. Optam, então, pela dissolução do vínculo e da sociedade que os une, separam suas vidas íntimas de forma definitiva e dividem o patrimônio familiar segundo as regras por eles escolhidas ou pela lei impostas quando da constituição do seu grupo familiar ${ }^{60}$.

Todavia, casos há em que o desfazimento do casal depara com outra questão de grande relevância e (certamente) de maior importância que o patrimônio e a vida íntima de cada um. Trata-se da existência de prole em estágio de formação, de prole não auto-suficiente e por isso incapaz de assumir todas as responsabilidades que a vida civil atribui a cada ser humano, em sua dignidade ${ }^{61}$. Daí porque esses seres continuem necessitando de cuidados e demandando atenção contínua e plena, da mesma forma que recebiam quando seus pais viviam unidos no mesmo grupo familiar. E isso porque "o cuidado parental é uma instituição altruísta, dirigida a fazer prevalecer o interesse da criança" ${ }^{2}$.

O que ocorre, assim, é que o esfacelamento do núcleo familiar primitivo necessita ser equacionado relativamente ao destino das crianças envolvidas, estabelecendo-se a guarda, decidindo-se quem a exercerá ${ }^{63}$, de que forma e em razão de quê. Como demonstra

${ }^{58}$ TEIXEIRA, Ana Carolina Brochado. Direito de visita dos avós. Revista Trimestral de Direito Civil, Rio de Janeiro, ano 3, v. 10, p. 59-77, 2002, p. 61.

${ }^{59}$ A legislação brasileira não contempla, de forma explícita, a possibilidade de dissolução da união matrimonial pela simples alegação de impossibilidade de manutenção da vida em comum, a menos que se trate de uma decisão conjunta e consensual dos membros do casal. Os pedidos unilaterais de dissolução da sociedade conjugal e do vínculo matrimonial, em leitura positivista da questão, precisariam estar esteados na demonstração da culpa de pelo menos um dos membros do casal. Não é, todavia, uma postura consentânea com a nova concepção de família eudemonista, na medida em que traz como consequiência a necessidade de manter unidas pessoas que, tendo agido conforme os deveres conjugais impostos pelo legislador na constância do matrimônio, vêem, simplesmente, escoar o amor que lhes unia, impedindo a manutenção de um grupo familiar que deve suprir as necessidades individuais (eros) por meio da consideração do outro (agape). A respeito da culpa: BAINHAM, Andrew. Men and women behaving badly: is fault dead in English family law? Oxford Journal of Legal Studies, Oxford, v. 21, n. 2, p. 219-238, 2001.

${ }^{60}$ PEREIRA, Áurea Pimentel. Divórcio e separação judicial no novo Código Civil. 11. ed. Rio de Janeiro: Renovar, 2004, p. 18-19; FERRAZ, Fernanda de Figueiredo. Separação e divórcio: doutrina e prática. São Paulo: Quartier Latin, 2005, p. 75.

${ }^{61}$ Veja-se, com bastante interesse, YOUF, Dominique. Penser les droits de l'enfant. Paris: Presses Universitaires de France, 2002, p. 74-77.

${ }^{62}$ SOTTOMAYOR, Maria Clara. O poder paternal como cuidado parental e os direitos da criança. In: SOTTOMAYOR, Maria Clara (Coord.). Cuidar da justiça de crianças e jovens: a função dos juízes sociais. Coimbra: Almedina, p. 9-63, 2003, p. 45.

${ }^{63}$ Assevera CAHALI, Yussef Said. In: CURY, Munir (Coord.). Estatuto da criança e do adolescente comentado. Comentários jurídicos e sociais. 7. ed. São Paulo: Malheiros, 2005, p. 145, que é de "se permitir a concessão da guarda do menor (rectius: da criança) a terceiros mesmo contra a vontade do titular do pátrio poder, se isto melhor atende[r] ao interesse do menor (rectius: da criança)" justamente em função do abrandamento de vetusta orientação que enxergava na guarda uma simples conseqüência do poder familiar, o que hoje não corresponde à realidade absoluta. Nesse trabalho, sempre que a expressão "menor" 
claramente Pénélope Agallopoulou, a determinação da guarda só pode ser feita com a intervenção de um tribunal, provocado por um dos indivíduos interessados ou por ambos, quando requerem a homologação de eventual acordo assinado entre os pais, uma vez que se encontra em jogo, justamente, o direito da criança à formação de sua personalidade e seu caráter. Até que isso ocorra, mesmo que os pais já não mais vivam juntos, eles continuam a exercer o poder-dever familiar de forma conjunta (tal qual ocorria anteriormente ${ }^{64}$ ) ainda que um deles detenha a guarda de fato das crianças ${ }^{65}$.

A necessidade da intervenção judicial é tão sensível no sistema jurídico brasileiro que o $\S 4^{\circ}$ do art. 1.584 do Código Civil, com a redação que lhe deu a Lei $n^{\circ} 11.698$, de 13 de junho de 2008, em vigor desde meados de agosto do mesmo ano, cria mecanismo para a punição do detentor da guarda em caso de alteração não autorizada ou de descumprimento imotivado de cláusula estabelecida na regulação da guarda, podendo-se, inclusive, impor a redução do número de horas de convivência com o filho ao violador da norma concreta.

O desfazimento dessa vida implica, assim, a ruptura das relações de afeto e mesmo das relações jurídicas travadas entre ambos, mas não tem o condão de transformar aquela família em uma família monoparental. Com efeito, uma vez dissolvida a família conjugal ou a família convivencial, subsistem em tese duas famílias em tudo muito assemelhadas às famílias monoparentais, posto que cada um dos genitores, seguindo as suas vidas pessoais, não se desincumbem, em regra, das funções paternais que lhes tocam. Nessa hipótese a criança passa a ter não uma, mas duas famílias, com as quais passa a conviver. Quer isso significar que a separação ou o divórcio de pessoas casadas ou a dissolução de uma união estável não atingem, em nada, as relações entre os filhos e cada um de seus genitores ${ }^{66}$. A

estiver assente, estará na acepção de ser humano incapaz em função da idade. Todas as vezes em que autores citados fizerem referência a "menor", na acepção de criança ou adolescente, chamar-se-á a atenção para tal fato por meio da indicação de se tratar de criança. Isso porque, para o direito internacional convencional (direito internacional dos direitos humanos e direito internacional privado da criança), criança é todo ser humano menor de 18 anos, não se fazendo a distinção entre criança e adolescente, tal qual ocorre no sistema brasileiro de inspiração interna, em que a distinção guarda maior pertinência com as consequiências sancionatórias impostas pelo sistema ao cometimento de atos infracionais.

${ }^{64}$ AGALlOPOULOU, Pénélope. L'enfant et la justice selon le droit hellénique. Revue Hellénique de Droit International, Atenas, v. 48, p. 267-276, 1995, p. 269.

65 Sobre os problemas que a manutenção da guarda de fato pode gerar no desenvolvimento psíquico das crianças e no resguardo de seus direitos, veja-se: ROCHA, Maria Isabel de Matos. Criança "devolvida". Quais são os seus direitos? Revista de Direito Privado, São Paulo, ano 1, v. 2, p. 74-113, 2000.

${ }^{66}$ E isso porque a separação judicial, por si, é capaz de extinguir os deveres de fidelidade recíproca e coabitação, vigente entre os cônjuges na constância da sociedade conjugal. O mesmo ocorrerá nas hipóteses de divórcio direto, porquanto nesse caso se esteja a dissolver o próprio vínculo matrimonial. A respeito: PEREIRA. Divórcio e..., cit., p. 22-23. Mas, em nenhuma dessas hipóteses, o vínculo parental havido entre genitor e prole será extinto, por óbvio, razão pela qual subsiste. PEREIRA. Divórcio e..., cit., p. 182. 
relação de afetividade construída pela criança continua sendo uma relação baseada no encontro do singular (o filho) com o plural (ambos os pais) ${ }^{67}$ e a reconstrução de tal percepção pode demorar a ocorrer, devendo os pais perceber o importante papel que desempenham na hipótese.

Todavia, como a vida conjunta até então levada por todos esses atores (pai, mãe e filhos) não pode subsistir justamente em razão da descontinuidade dos propósitos comuns e do afeto recíproco entre os agentes capazes envolvidos ${ }^{68}$, resta solucionar a questão atinente ao destino das crianças e dos adolescentes envolvidos. Se é certo que o melhor para eles e seu desenvolvimento sociopsíquico consistiria na manutenção da família sadia e hígida ${ }^{69}$, também é certo que não se poderia obrigar pessoas que não mais comungam dos mesmos objetivos a manter uma vida comum.

Bem por isso, cabe à lei estabelecer critérios que garantam à criança certos itens necessários a seu desenvolvimento como: lar, educação, convivência familiar, além da convivência com aquele de seus genitores que acabe por se afastar do lar familiar originário.

${ }^{67}$ DOLINGER. O direito e o..., cit., p. 236. Daí porque SMEETS, Carla. Um advogado das crianças. Infância e Juventude. Lisboa, n. 2, p. 43-60, 2003, p. 47-48, ao formular uma série de indagações que se poderiam dirigir a uma criança indiretamente envolvida em processo de divórcio, conclua que a única respostas que traduziria exatamente o desejo da criança seria aquela endereçada à pergunta "Gostarias de pão com queijo creme ou creme de chocolate". Às demais ("Tu gostarias de viver com a tua mãe ou o teu pai?, Gostarias de ir de férias com o teu pai [ou a tua mãe] por duas ou três semanas?"), ela não pode responder por representarem escolhas que ela, no mais das vezes, não consegue fazer (SMEETS, p. 48), justamente por se tratar de uma relação afetiva singular/plural (DOLINGER, p. 236).

${ }^{68}$ PEREIRA. Divórcio e..., cit., p. 64-65, narra o surgimento, no sistema brasileiro, da chamada "separação sem causa" por simples ruptura da vida em comum. Nesse caso, exige-se que os cônjuges estejam separados de fato há mais de um ano e que demonstrem a impossibilidade de reconstituição da vida marital. Entende a autora, apegada ao sistema da demonstração de culpa, que o prazo de um ano é exíguo, propugnando por sua dilação para dois anos, de lege ferenda. Não se concorda, no entanto, com a posição da autora, já que se entende que a necessidade de demonstração da culpa ou do lapso temporal pode impedir que a família - funcional e eudemonista - opere a contento. Com efeito, nas hipóteses em que um dos cônjuges prefira pôr fim à relação, encontrando a pretensão do outro no sentido de manter a convivência formalizada pelas núpcias, estará o primeiro obrigado a demonstrar a culpa do recalcitrante, que pode simplesmente não existir. Nesse caso, a saída que o sistema lhe abre - na medida em que não existe o consenso para a separação - é afastar-se da vida comum, por um ano, para requerer a "separação sem causa". Ora, nesse caso, abrir-se-á um flanco de mágoas e ressentimentos que certamente atingirá o emocional das crianças e poderá levar o cônjuge abandonado a requerer, qualquer que seja a motivação interna, a separação litigiosa por descumprimento do dever de coabitação ou, ainda, de fidelidade, imaginando-se que o cônjuge que deixou o lar conjugal reconstrua sua vida afetiva. E isso porque, até que decorrido o prazo legal, subsiste a possibilidade de requerimento da separação com base na culpa. Apenas depois de transcorrido o lapso temporal é que será possível deixar de fazer referência à "culpa de um ou outro cônjuge ou qualquer outra causa para a separação judicial ou o divórcio[.] Prova-se apenas a separação de fato e a decorrência do lapso temporal[.] os termos são puramente objetivos, sem referência alguma à responsabilidade pela ruptura". FERRAZ. Separação..., cit., p. 83.

${ }^{69}$ A respeito, muito embora não se concorde em absoluto com o texto, por seu caráter preconceituoso: BAVA BUSSALINO, Pablo. Los hijos ante la disolución conyugal: el divorcio o la enfermedad del amor. Revista del Colegio de Abogados de La Plata, La Plata, v. 38, n. 59, p. 61-69, 1998, p. 63-64. 


\section{A ATRIBUIÇÃO DA GUARDA}

No momento da separação, conforme certo posicionamento doutrinário, o sistema jurídico destaca alguns dos atributos do poder familiar e os consolida em instituto novo, denominado guarda, atribuindo-o a um ou a ambos os genitores de forma conjunta ou alternada $^{70}$. Relativamente àqueles outros atributos do poder familiar que não foram destacados e consolidados na guarda, subsistirão e serão exercidos de forma concomitante por ambos os genitores, pois, como lembra Maria Clara Sottomayor,

“A regulação do poder paternal, após o divórcio [a separação ou a dissolução da união estável], não pode ser usada como um instrumento de transformação dos papéis familiares, devendo, antes, reflectir a forma como os pais distribuíam entre si as tarefas relativas ao cuidado dos filhos, durante a constância do casamento [ou da união estável]"’11.

Nesse sentido, a guarda pode ser atribuída com exclusividade a um dos genitores, ou a ambos de forma alternada, configurando verdadeira atribuição sucessiva de guardas simples segundo cadência temporal preestabelecida, restando, por fim, a possibilidade de atribuí-la de forma conjunta, com exercício simultâneo por ambos os genitores, hipótese em que se terá dado vazão e perfeita conformação fática à idéia de que a "perenidade do casal parental deve sobreviver à fragilidade do casal conjugal”,72.

Antes de se proceder a análise detalhada de cada uma das formas mencionadas, saliente-se que há quem veja, na doutrina, a pertinência de se atribuir a guarda a um dos genitores sempre que estes mantenham entre si uma relação fática, como é o caso da união estável. O argumento nesse sentido é o de que, nessas uniões, há "sempre o risco de uma separação, razão pela qual o interesse do menor (rectius: da criança) comanda que, desde a origem, ele seja confiado a um só de seus pais"73. Todavia, parece não ser essa a idéia

\footnotetext{
${ }^{70}$ Pois, como afirma CAHALI, Yussef Said. A importância do instituto da guarda. Revista de Jurisprudência do Tribunal de Justiça do Estado de São Paulo, São Paulo, v. 25, n. 133, p. 9-18, 1991, p. 13: "a guarda não pressupõe prévia suspensão ou destituição do pátrio poder, eis que não incompatível com este".

${ }^{71}$ SOTTOMAYOR, Maria Clara. Divórcio, poder paternal e realidade social: algumas questões. Direito $e$ Justiça: Revista da Faculdade de Direito da Universidade Católica Portuguesa, Lisboa, v. 11. n. 2, p. 161172, 1997, p. 170.

72 DEVICHI, Jacqueline Rubellin. Apud: GRISARD FILHO, Waldyr. Guarda compartilhada: quem é o melhor para decidir a respeito? Revista Jurídica, Porto Alegre, v. 47, n. 268, p. 28-31, 2000.

73 STRENGER, Guilherme Gonçalves. Interesse do menor na atribuição da guarda. IOB - Repertório de Jurisprudência: Civil, Processual, Penal e Comercial, São Paulo, n. 19, p. 525-524, out. 2002, p. 525.
} 
pertinente ao sistema como um todo ${ }^{74}$. Com efeito, as pessoas que vivem em união estável, não obstante não tenham assumido o vínculo matrimonial como formalização de sua convivência, tiveram desde logo o intuito de constituir uma família com a característica de ser desprovida dos aspectos formais, mas merecedora de toda a proteção do Estado.

Dessa forma, se uma criança nasce em uma união estável e é registrada em nome de ambos os membros da família convivencial, não parece acertado dizer que os companheiros, enquanto pais da criança, devam recorrer ao Poder Judiciário para que este indique qual deles deve ser o guardião do bebê recém-nascido, sob o argumento de que estariam mais propensos a se separar! Além do que, não há fundamento jurídico para um pedido como esse, na exata medida em que a legislação brasileira regula a atribuição da guarda apenas nas hipóteses em que haja separação (em sentido amplo) dos pais (Código Civil de 2002) ou, ainda, nos casos de regulação da guarda de fato (Estatuto da Criança e do Adolescente $)^{75}$. No caso imaginado por Guilherme Strenger, não há falar em separação, pois os pais vivem juntos, de forma estável, ostensiva e afetiva, no seio de uma família. Muito menos em destituição do poder familiar por parte de qualquer dos genitores. Ambos os pais permanecem convivendo, no seio de uma única família à qual aportou uma criança recém-nascida.

\subsection{A escolha do sistema de atribuição da guarda}

A doutrina brasileira, apegada à idéia de que a guarda tem por escopo consolidar alguns dos atributos do poder familiar, que serão exercidos com exclusividade por um dos genitores ou por ambos, conforme o caso, estabelece distintas formas de atribuição do direito de guardar os filhos. Assim, as subdivisões do presente tópico reproduzem o posicionamento doutrinário, em perspectiva narrativa. A reconstrução da questão, em perspectiva sistemática, é apresentada adiante, no item 4.

\footnotetext{
${ }^{74}$ Não sem razão, afirma GOLDSTEIN, Joseph I. ¿En el interés superior de quién?. In: BELOFF, Mary (Org.). Derecho, infancia y familia. Barcelona: Gedisa, p. 115-129, 2000, p. 115, que "la ley supone, y debe suponer, que los niños son titulares del derecho a ser cuidados conjuntamente por sus padres. En efecto, es generalmente en el interés superior del niño que sus padres tienen la custodia conjunta - no importa que ellos hayan o no estado casados alguna vez".

${ }^{75}$ Veja-se, a respeito: CAHALI e BECKER, Maria Josefina. In: CURY (Coord.). Estatuto..., cit., p. 144-151; SCHREIBER, Elisabeth. Os direitos fundamentais da criança na violência intrafamiliar. Porto Alegre: Ricardo Lenz Editor, 2001, p. 131. Sobre os aspectos processuais da Justiça de Infância e Juventude, competente para as hipóteses de atribuição da guarda previstas no ECA, veja-se, em perspectiva teórica: FANNI, Luisella (Org.). Quale processo per la famiglia e i minori? Milano: Giuffrè, 1999.
} 


\subsubsection{Guarda unilateral}

A guarda, quando for caso de a atribuir, pode ser deferida sob a forma de guarda unilateral $^{76}$, pela qual a prole ficará sob a responsabilidade daquele genitor que consiga se enquadrar na hipótese legal, apresentando todos os requisitos exigidos pela lei, sejam os principais ou os subsidiários. Esses requisitos exigidos pela lei para se saber qual dos genitores exercerá a guarda da prole variaram muito ao longo de nossa história legislativa, evoluindo sobremaneira desde as Ordenações até a legislação em vigor, mas ainda há muito a melhorar nesse campo, adequando-o aos princípios reitores do Código Civil e à sistemática de todo o sistema jurídico (de fontes nacional e internacional), como se verá adiante.

Uma vez definida, pelo magistrado que preside o processo, que a atribuição da guarda deve realizar-se pela forma unilateral, o genitor-guardião passa a se responsabilizar pela prestação de assistência moral e educacional à criança, decidindo com exclusividade a respeito do melhor instituto educacional onde matricular o filho, optando pelos cursos extracurriculares que entender mais condizentes para a educação que almeja para a criança $^{77}$, fixando-lhe o domicílio com exclusividade etc. Ao genitor não-guardião impõese a obrigação de supervisionar os interesses dos filhos e a forma como tais interesses são ou não atendidos pelo guardião, verificadas as justificativas por este apresentadas $(\mathrm{CC}$, art. $\left.1.583, \S 3^{\circ}\right)$.

Em todas essas hipóteses, o genitor-guardião deve consultar a criança envolvida e considerar as suas opiniões, pois o art. 18, § 1., $2 .^{a}$ parte, da Convenção sobre os direitos da criança determina que "caberá aos pais ou, quando for o caso, aos representantes legais a responsabilidade primordial pela educação e pelo desenvolvimento da criança. Sua

\footnotetext{
${ }^{76}$ Antes chamada de guarda simples, a lei $11.698 / 2008$ passou a denominá-la de guarda unilateral. Veja-se, a propósito, CANEZIN, Claudete Carvalho. Da guarda compartilhada em oposição à guarda unilateral. Revista Brasileira de Direito de Família, Porto Alegre, ano 6, n. 28, p. 5-25, 2005.

${ }^{77}$ Nesse sentido: "En particular debe tenerse en cuenta que las decisiones de quien ejerce la tenencia resultan, con frecuencia, condicionadas por las circunstancias que le rodean. Más explícitamente, la educación comprende una serie de límites y decisiones que deben ser tomadas a diario y que sólo pueden estar a cargo de quien tiene la responsabilidad permanente sobre el menor. Se trata de decisiones que non son buenas o malas en sí mismas - podríamos referirnos a ellas como decisiones operativas - como horarios, tanto de salidas como dentro del hogar, vestimenta, gastos diarios, colegio al que se concurre". STILERMAN, Marta N. Menores. Tenencia. Régimen de visitas. 3. ed. Buenos Aires: Editorial Universidad, 1997, p. 172 - destaque inexistente no original compulsado.
} 
preocupação fundamental visará ao interesse maior da criança". Como a função da família é garantir e privilegiar a formação intelectual e sociopsíquica da criança mediante a valorização do afeto, deve ser garantida a mais ampla participação dos jovens em seu processo educacional, o que passa pelo diálogo ponderado entre a criança e seus pais a fim de se atingir o consenso entre os anseios daquela e as possibilidades destes. É o futuro profissional e intelectual da criança que está em jogo, motivo pelo qual suas opiniões devem encontrar apoio na liberdade de expressão, além de respeito e compreensão por parte dos pais que devem exercer suas funções, de forma consciente, dentro dos parâmetros democráticos traçados pelo direito contemporâneo. Ademais, o art. 29 da citada convenção traça critérios que devem balizar a educação das crianças. Entre eles, destaca-se o de "preparar a criança para assumir uma vida responsável numa sociedade livre, com espírito de compreensão, paz, tolerância, igualdade de sexos e amizade entre todos os povos, grupos étnicos, nacionais e religiosos e pessoas de origem indígena". Ora, tais estados anímicos só podem ser absorvidos pela criança por meio do diálogo e da saudável convivência familiar. A educação deve ser entendida, assim, não apenas em seu aspecto formal, e deve incluir, por isso, a educação religiosa (e o correlato direito de manifestação e profissão de um culto, ainda que diverso do de seus pais), política (e o correlato direito de participar da vida política, na forma da lei) etc. ${ }^{78}$.

O direito à educação pressupunha, no passado, o dever de correção, exercido pelos pais em face dos filhos de forma ilimitada, sempre que estes excediam os limites que lhes eram fixados. Todavia, a fronteira entre o exercício do dever de correção e a imposição de maustratos às crianças é assaz tênue e demanda cuidados por parte dos genitores, uma vez que a configuração da violência familiar imposta pelos pais pode servir, em sendo o caso, para a destituição da guarda ${ }^{79}$. Bem por isso, afirma Maria Clara Sottomayor que "o direito dos pais educarem os filhos não abrange o direito de os agredir, de ofender a sua dignidade, integridade física e psíquica ou liberdade ${ }^{, 80}$.

O genitor alijado da convivência diuturna com a prole terá, ainda, o direito de visitas garantido e deverá contribuir para o sustento material da prole, pagando parte de suas

\footnotetext{
${ }^{78}$ Cf. MONACO, Gustavo Ferraz de Campos. Direitos da criança e adoção internacional. São Paulo: RT, 2002, p. 74-75.

${ }^{79}$ GROSMAN, Cecília P. El maltrato infantil en la familia: encuentro entre lo público y lo privado. In: CADOCHE, Sara Noemí (Dir.). Violencia familiar. Buenos Aires: Rubinzal-Culzoni Editores, p. 165-191, 2002 , p. 169.

${ }^{80}$ SOTTOMAYOR. In: SOTTOMAYOR (Coord.). Cuidar da..., cit., p. 48.
} 
despesas, na proporção do que for determinado em acordo ou sentença ${ }^{81}$. O dever de manutenção material subsiste até o implemento da idade de 18 anos, que se tem estendido até o término dos estudos universitários na maioria dos países.

De outra parte, como é vedado a qualquer um dos pais obstar a convivência de seu filho com o outro genitor, pessoa com quem conviveu, na normalidade dos casos, desde a mais tenra idade, deve ser estabelecido um prévio acordo ou uma determinação judicial supletiva que fixe um minucioso calendário de visitação, baseado em certa alternância dos períodos de férias e dos finais de semana, com o intuito de se garantir a ambos os genitores a possibilidade de prévio planejamento de suas próprias vidas profissionais a fim de conviverem harmoniosamente com a prole.

A questão da guarda unilateral, assim, coloca-se no natural afastamento do genitor que apenas pode visitar a criança, uma vez que ele não participa das decisões mais comezinhas relativas à vida do filho, sua educação e seu desenvolvimento, cabendo-lhe somente, em caso de discordância com a decisão tomada, comprovar o prejuízo - ainda que eventual para a criança, requerendo, se for o caso, o deferimento da guarda para si.

\title{
2.1.2. Guarda alternada
}

A guarda podia ser atribuída, antes de agosto de 2008, ainda, de forma alternada, quando se estipulava uma maneira de contagem consecutiva de prazos (dias, semanas, meses), cabendo a cada qual dos pais a posse $e^{82}$ da criança por igual período.

\begin{abstract}
"Enquanto um detenha a guarda, o outro se beneficiará do direito de visita, de coabitação e de fiscalização. No fim de cada período, os papéis são invertidos. Cada um conserva, pois, o exercício da autoridade parental e não é necessário transferência judicial para que a criança passe de um cônjuge ao outro. Modifica-se somente o exercício da guarda" ${ }^{\sharp 3}$.
\end{abstract}

Tal forma - se apresentava a vantagem de que a guarda unilateral se ressentia, qual

\footnotetext{
${ }^{81}$ Vejam-se, a respeito, os itens 3.1. e 3.2., infra, nesse capítulo.

82 Rui Barbosa já se manifestara contrariamente à expressão posse de filhos, justamente por serem eles pessoas e não coisas ou direitos. Com efeito, deve-se evitar a expressão a todo o custo, tendo ela sido empregada nesse passo para deixar consignada a crítica. A esse respeito, PEREIRA, Áurea Pimentel. Da proteção da pessoa dos filhos na dissolução da sociedade conjugal: tratamento dado pela legislação brasileira. Revista Doutrinária, Rio de Janeiro, v. 4, n. 4, p. 49-53, 2001, p. 49-50.

${ }^{83}$ STRENGER. Interesse do menor..., cit., p. 525.
} 
seja, a participação de ambos os genitores na condução da vida da prole, uma vez que ambos conservavam ligações quotidianas com seus filhos ${ }^{84}$ - trazia, por outro lado, o inconveniente de tornar dificultosa a adaptação da criança a dois bairros diferentes, a dois grupos de amigos diversos etc., mas, principalmente, a duas esferas de atuação da autoridade, por vezes com regras e limites dessemelhantes ${ }^{85}$. Além disso, a criança se ressentia de uma residência habitual fixada ${ }^{86}$.

Segundo Guilherme Gonçalves Strenger, essa forma de atribuição da guarda era vantajosa ainda por obrigar o genitor afastado momentaneamente da guarda a se manter ciente do desenvolvimento moral e educacional de seus filhos, sob pena de impingir-lhes uma ruptura cultural muito drástica quando da alternância necessária ${ }^{87}$.

Todavia, parece que a forma de benefícios detectada pelo autor pode ser conseguida, atualmente e com maiores vantagens, pela concessão da guarda por outros moldes, seja em sua forma unilateral, seja em sua forma compartilhada.

Quanto à guarda unilateral, o legislador de 2008, ao alterar os dispositivos do Código Civil acerca do tema, explicitou a obrigação de que o não guardião mostre-se atento à satisfação dos interesses dos filhos por parte do detentor da guarda, devendo aquele proceder a sua supervisão.

Ainda no que se refere a esta forma particular de se conceder a guarda, alternando-se os períodos de convivência com um e outro dos genitores, deve-se consignar a má redação dada ao inciso II do art. 1854 do Código Civil pela Lei 11.698, de 13 de junho de 2008. Ao estabelecer que a guarda, unilateral ou compartilhada, poderá ser decretada pelo juiz, atendidas as necessidades específicas dos filhos, andou bem o legislador ao permitir que o interesse da criança esteja na base da decisão judicial.

Mas já não andou bem o legislador ou estatuir o critério alternativo para a decisão com base na distribuição de tempo necessário ao convívio dos filhos com o pai ou com a mãe. E não andou bem justamente por abrir flanco hermenêutico a que certamente acorrerão os defensores da alternância da guarda ao se utilizar da expressão "distribuição de tempo necessário". Assim, uma lei que procurou positivar certo avanço doutrinário e

${ }^{84}$ FULCHIRON, Hugues. In: RUBELLIN-DEVICHI, Jacqueline (Dir.). Droit de la famille. Paris: Dalloz, 2001, p. 701, n⿳⺈ 1908.

${ }^{85}$ Nesse sentido: FONSECA, Priscila Maria Pereira Corrêa da. Modificação da guarda de filhos. Revista do Advogado, São Paulo, n. 25, p. 76-82, maio 1988, p. 77.

${ }^{86}$ FULCHIRON. In: RUBELLIN-DEVICHI (Dir.). Droit..., cit., p. 701, no 1908.

${ }^{87}$ STRENGER. Interesse do menor..., cit., p. 525. 
jurisprudencial que defendia as formas unilateral e compartilhada de exercício da guarda, em detrimento de sua alternância - que, aliás, visava extirpar da praxe jurídica nacional, uma vez que nascida de forma inadequada de interpretação - poderá ser a responsável por ser recrudescimento.

Deve-se, assim, defender com veemência que o texto legislativo consagra a possibilidade de se optar pela guarda compartilhada - em detrimento da guarda unilateral nos casos em que os filhos possam se beneficiar do maior tempo de convívio com o genitor não-guardião, mas já não se deve dar qualquer força aos argumentos que pretenderem ressuscitar forma de atribuição da guarda cujas vantagens apontadas podem ser melhor obtidas pelas duas únicas formas hoje existentes no sistema, a saber, a guarda unilateral e a guarda compartilhada (art. 1583, caput, CC).

\subsubsection{Guarda compartilhada}

$\mathrm{Na}$ guarda compartilhada a guarda se desdobra em duas facetas, conforme bem explica Waldyr Grisard Filho: "a guarda compartilhada legal, ou, simplesmente, guarda jurídica, corresponde [a] compartilhar todas as decisões importantes relativas aos filhos", como a escolha dos meios de educação, dos cursos extracurriculares, da educação religiosa, da moral etc., enquanto "a guarda compartilhada material, ou, simplesmente, guarda física,

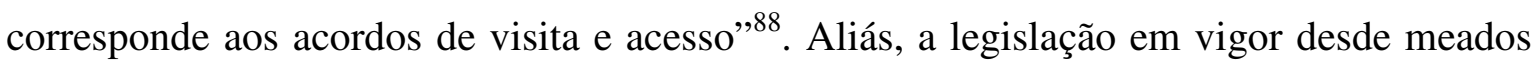
de 2008 estabelece a obrigatoriedade de que o magistrado, na audiência de conciliação, informe ao pai e à mãe o significado da guarda compartilhada, a similitude de deveres e direitos atribuídos a ambos, independentemente da atribuição da guarda física e as sanções aplicáveis em caso de descumprimento das cláusulas decorrentes de sua atribuição.

A menção que se fez acima ao direito de acesso é importante nessa seara, porquanto parece ser destituído de toda razão permitir que o genitor-guardião - despido da guarda

${ }^{88}$ GRISARD FILHO. Guarda compartilhada: quem é..., cit., p. 30 (destaques inexistentes no original). SANTOS, Eduardo dos. Direito da família. 2. ed. Coimbra: Almedina, 1999, p. 539 afirma que a guarda deve ser atribuída a um dos progenitores, à terceira pessoa ou a estabelecimento de (re)educação ou assistência, "porque dos dois [pai e mãe] não pode ser". No entanto, mais adiante afirma que os pais podem acordar a respeito do exercício do poder paternal, estabelecendo que ele seja exercido "em comum dos dois, decidindo as questões relativas à vida do filho em condições idênticas às que vigoravam para esse efeito na constância do matrimónio". Assim, ao que parece, é lícito afirmar que os portugueses referem-se à guarda tão-só no sentido de guarda física, ao passo que aquilo a que chamamos guarda jurídica, eles chamam poder paternal. Como se verá adiante, item 4., parece assistir razão teórica a tal posicionamento. 
física - mantenha um direito de acesso irrestrito à prole, na medida em que isso possa afetar a própria privacidade do genitor-guardião físico. Assim, quando atribuída a guarda em sua forma compartilhada, é salutar que se estabeleça um sistema de visitação e que se restrinja o acesso do não-guardião físico à prole sempre que uma liberdade ilimitada de acesso possa pôr em risco o direito à privacidade e à intimidade do genitor-guardião físico.

Como salienta Maria Clara Sottomayor, essa forma de atribuição da guarda necessita de um amadurecimento social por parte dos pais que implique a capacidade de perceber e compreender que as relações entre eles travadas diferenciam-se das relações que devem travar, cada um deles, com a prole comum, o que passa, certamente, pelo respeito às relações pessoais do outro genitor. Dessa forma, enquanto essa revolução mental não tiver ocorrido, a atribuição da guarda compartilhada, em que pese a beleza principiológica que encerra, permanecerá desempenhada de forma tal que o genitor-guardião físico tomará as decisões e agirá no sentido do cuidado com a prole, ao passo que o outro genitor, desprovido da guarda material, mas co-titular da guarda jurídica, terá seu papel reduzido ao de mero abonador das decisões tomadas pelo outro ${ }^{89}$, o que certamente não se coaduna com os fins sociais que o instituto da guarda compartilhada visa atender.

Daí por que se possa afirmar que tal modo de atribuição da guarda, capaz de se apresentar como a mais consentânea com o desenvolvimento da criança, exige, por outro lado, a civilidade e a isenção de espírito tantas vezes necessárias nessa seara, mormente quando já não há, entre os pais da criança, um projeto de vida comum a ambos que não o de ver a criança, sua filha, bem formada, sã e cheia de vida.

Daí porque pareça afoita a disposição legal esculpida no parágrafo segundo ado artigo 1584 do CC, em sua redação atual, ao estabelecer que, sempre que não houver acordo entre o pai e a mãe quanto à guarda da prole, será aplicada, sempre que possível, a guarda compartilhada. Parece haver a intenção - bem intencionada, mas pouco prática - de jurisdicizar o que não é fato, abrindo-se a possibilidade de que o instituto descambe, corriqueiramente, para uma guarda unilateral de fato, expondo um dos genitores às sanções previstas no parágrafo quarto do mesmo dispositivo, com todas as nefastas conseqüências que tal situação pode acarretar para a futura convivência do genitor com sua prole.

Outra desvantagem dessa forma de atribuição da guarda, apontada por Waldyr Grisard Filho, diz respeito à obrigatoriedade de que o pai e a mãe, co-guardiões da criança,

${ }^{89}$ SOTTOMAYOR. Divórcio, poder paternal..., cit., p. 169-170. 
permaneçam residentes da mesma cidade, pois só assim seria possível a participação efetiva e constante de ambos na vida da prole $^{90}$. A se aceitar tal argumento - de resto bastante plausível - percebe-se a incompatibilidade do instituto da guarda compartilhada com os casos plurilocalizados.

\subsection{A escolha do guardião}

A legislação estabelece critérios para se concluir a quem deva ser atribuída a guarda em caso de dissolução da vida em comum do casal. Ao longo da história legislativa brasileira, o critério já se alterou sobremaneira, ora vinculando a concessão da guarda a fatores relativos a gênero e idade, ora atrelando o tema a situações negativas - como no caso da verificação da culpa -, ora fazendo valer uma situação tendencialmente positiva, mas passível de comprovação apenas pelo caráter negativo de comparação a contrario sensu.

Além disso, a forma de redação dos artigos de lei sofreu enorme evolução na medida em que passou a revelar, com a modificação dos valores sociais, uma maior preocupação com a situação das crianças envolvidas, compreendendo a sua situação de sujeitos de direito e não de objeto.

Assim, nas Ordenações reinóis vigentes no Brasil, a criança, encarada como objeto, devia ficar em poder do pai, genitor do sexo masculino, obrigando-se a mãe separada a criar os filhos de peito até que estes completassem 3 anos de idade. Percebe-se claramente o caráter sexista e de penalidade imposto pela lei. Certamente em virtude de sua ousadia e audácia por abandonar o lar conjugal, deixando a proteção do marido, chefe de família, proprietário dos bens, a mulher ficava obrigada a terminar de criar e alimentar a prole de tenra idade, sendo-lhe imposta a pena de perda dos filhos sempre que estes fossem maiores de 3 anos.

Com a aprovação do Código Civil de 1916, a criança permanece encarada como objeto, mas o caráter de penalidade atribuído à mãe já não é fixo e a guarda beneficia o cônjuge inocente na separação, ou seja, aquele que não deu azo à separação do casal. Se, todavia, a culpa fosse concorrente, ou seja, se restasse comprovada a culpa de ambos os cônjuges para a separação, a lei determinava que a guarda fosse atribuída em caráter subsidiário

${ }^{90}$ GRISARD FILHO, Waldir. Guarda compartilhada: um novo modelo de responsabilidade parental. 3. ed. São Paulo: RT, 2006, p. 197. 
mantendo-se os filhos de sexo feminino sob poder da mãe e entregando-se os filhos de sexo masculino ao pai, mas apenas se estes fossem maiores de 6 anos, posto que até essa idade as crianças necessitariam do desvelo materno ${ }^{91}$. Mas essa regra, supletiva, não era absoluta, pois se admitia que o juiz, diante do caso concreto, decidisse de forma diversa (muito embora a lei não traçasse critérios para essa outra forma de decisão - como faz agora o legislador e como se verá adiante) ou homologasse acordo entre os genitores.

Felizmente, a redação originária do Código Civil de 1916 não subsistiu, sofrendo alteração quando da aprovação do Estatuto da mulher casada, que veio modificar o critério subsidiário, excluindo a separação da prole segundo o sexo dos filhos. Com o Estatuto e, posteriormente, com a Lei do divórcio, a guarda permaneceria deferida ao cônjuge inocente, mas passava-se a garantir, em hipótese de culpa concorrente ou de inexistência da culpa, a atribuição supletiva da guarda à mãe $e^{92}$, a menos que se comprovasse que essa situação poderia causar danos de ordem moral e intelectual às crianças envolvidas.

Percebe-se claramente que a disputa pela guarda, então, sempre que não se conseguisse acordo, dependeria da comprovação de uma conduta negativa da parte do outro dos envolvidos, conduta negativa esta que, na maioria dos casos, era despercebida pelo cônjuge na constância do casamento, em razão da confiança mútua ainda existente e que, agora, com o desgaste da relação e o esgarçamento da confiança, passa a ser perceptível ${ }^{93}$.

No entanto, tal situação decorre, em verdade, da opção do legislador pela manutenção da culpa como causa para os pedidos de separação ou divórcio ${ }^{94}$. Com efeito, quando o legislador exige que a separação ou o divórcio só possam ocorrer por decurso de tempo ou por demonstração de culpa em decorrência da inobservância de deveres conjugais (Verschuldensprinzip), mas não faz referência à simples e mais corriqueira das causas, qual

${ }^{91}$ Conferir posição crítica em RODRIGUES, Silvio. Comentários ao Código Civil, v. 17. In: AZEVEDO, Antônio Junqueira de. (Coord.). São Paulo: Saraiva, 2003, p. 204, quando afirma: "ademais, filho não é gado, que se separa com base na idade, na compleição e no peso, sendo talvez conveniente criar a família unida".

92 A perda de preferência da mãe no atual sistema é uma conseqüência da plena equiparação entre homens e mulheres. Cf. CABRAL, Karina Melissa. A mulher e o novo Código Civil: a confirmação do princípio da isonomia. Revista de Direito Privado, São Paulo, ano 5, v. 17, p. 135-150, 2004, p. 147. Veja-se, também, a interessante análise de MARQUES; CACHAPUZ; VITORIA. Igualdade..., cit., p. 19-21

93 SMEETS. Um advogado..., cit.,p. 45.

${ }^{94}$ Diferentemente do que ocorria à luz da legislação anterior, em que a culpa, além de servir de causa para a separação ou o divórcio, servia também para imposição de sanções às partes (perda da guarda, dever de pagar pensão, perda do nome do marido), no novo Código Civil brasileiro "a culpa é tratada apenas como elemento que possibilita o pedido de separação judicial litigiosa”. FERRAZ. Separação e..., cit., p. 154. No mesmo sentido, quanto ao direito argentino, em que permanece o critério: STILERMAN. Menores..., cit., p. 118. 
seja, a impossibilidade de manutenção da vida em comum (Zerrüttungsprinzip) ${ }^{95}$, é-lhe muito fácil estender esse critério para um tema conexo àquele, sem atentar para o fato de que a causa da separação e do divórcio pode e deve ser uma, posto que atinente à relação do casal, e a causa para a atribuição da guarda pode e deve ser outra, atinente às relações travadas pelos genitores com sua prole, e individualmente consideradas ${ }^{96}$.

Trata-se de típico caso de imposição de sanção com finalidade retributiva indireta (sanction par finalité), caracterizada pela vontade, da autoridade que a edita, de retribuir um comportamento particular reprovável (a falta) com a imposição de uma consequiência desagradável (a sanção) que não apresenta razão direta de causa e conseqüência. No âmbito do direito de família, as sanções retributivas indiretas são, normalmente, sanções acessórias, que não podem ser impostas sem que uma sanção principal tenha tido lugar ${ }^{97}$. Assim, a sanção de ser excluído da guarda de seus filhos era, na vigência do sistema anterior, conseqüência (sanção acessória ou sanction par finalité) de sanção precedente, de caráter principal, caracterizada pela responsabilidade pela dissolução do matrimônio. No sistema atualmente vigente subsiste tão-somente a possibilidade de aplicação das chamadas sanções curativas (sanction par essence), na medida em que a sanção remanesce como conseqüência do próprio ato praticado e passa a guardar relação de pertinência apenas com essa realidade fática, não se estendendo para outras searas ${ }^{98}$. Permanecem a culpa e a sanção respectiva, mas sob outros fundamentos ${ }^{99}$. A tentativa é, assim, a de tratar juridicamente as conseqüências da culpa, evitando que remanesça a situação jurídica em que esta se configura como tal ${ }^{100}$. No caso de separação ou divórcio, fala-se em sanção capaz de demonstrar a falência da relação precedente, manifestada pela atuação culposa de um ou de ambos os envolvidos ${ }^{101}$.

Nesse sentido, mostra-se de suma importância a modificação legislativa determinada

95 VILLELA, João Baptista. Liberdade e família. Movimento Editorial da Revista da Faculdade de Direito da UFMG, Belo Horizonte, v. 3, série Monografias, n. 2, p. 16-46, 1980, p. 39.

${ }^{96} \mathrm{Se}$ isso passou despercebido ao legislador até 2002, a jurisprudência brasileira parece ter acompanhado a doutrina mais cedo, alterando em muitos julgados o critério para atribuir a guarda dos filhos incapazes. Assim: RAMOS, Patricia Pimentel de Oliveira Chambers. O poder familiar e a guarda compartilhada sob o enfoque dos novos paradigmas do direito de família. Rio de Janeiro: Lumen Juris, 2005, p. 100 e nota 77, p. 102 a 107, com citação de inúmeras decisões do TJRJ, TJRS e TJMG.

${ }^{97}$ DESNOYER, Christine. L'évolution de la sanction en droit de la famille. Paris: L'Harmattan, 2001, p. 4849.

${ }^{98}$ DESNOYER. L'évolution..., cit., p. 62-63.

99 DESNOYER. L'évolution..., cit., p. 215. Afirma a autora, mais adiante, que "l'abrogation de la sanction accessoire peut avoir deux causes diffèrentes: soit le mécanisme juridique qui en est le support est supprimé; soit il est maintenu, mais son fondement renouvelé” (p. 233).

${ }^{100}$ DESNOYER. L'évolution..., cit., p. 299.

${ }^{101}$ DESNOYER. L'évolution..., cit., p. 318 e s. 
pelo Código Civil de 2002 quando estatui, no art. 1.583, § $2^{\circ}$ (NR), que o critério principal para a atribuição da guarda deixe de ser a existência de culpa por parte de um dos cônjuges e da correlativa inocência do outro no que concerne ao divórcio ${ }^{102}$. Certamente andou bem o legislador atual quando fez recair o critério de atribuição da guarda em algo que é de suma importância para o desenvolvimento da pessoa humana da criança, ou seja, já não mais se discute a respeito de culpa dos cônjuges ou companheiros quando a questão sub lide seja a atribuição da guarda aos genitores.

A discussão já não mais se dá pela negativa, ou seja, pela atribuição da culpa, mas se faz pelo critério positivo da comprovação de melhores condições para exercer a guarda. Em que pese o avanço representado pela troca de critérios, pode-se perceber com meridiana clareza que a discussão em torno de melhores condições para exercer a guarda só se pode realizar por comparação. Com efeito, algo só é melhor se a coisa comparada for pior. Da mesma forma, um genitor só terá melhores condições se o outro possuir piores condições. Nenhuma discussão a esse respeito poderá demonstrar melhores condições se não o fizer pela negativa, isto é, se não partir da comparação, comprovando que o outro genitor leva alguma forma de desvantagem nessa pendenga.

Não por outra razão, exige-se que a guarda unilateral seja concedida ao genitor que, objetivamente, conseguir demonstrar possuir mais aptidão para propiciar aos filhos afeto, saúde, segurança e educação. Acredita-se, seriamente, que a intenção do legislador foi a de se referir à saúde mental e psíquica da criança, bem como a sua educação informal e social, além da segurança enquanto sentimento de bem estar e proteção. Não se acredita que fatores como planos de saúde, segurança institucional e educação em bons colégios possam conformar os critérios legais sob pena de se estabelecer um retorno a critérios suscetíveis de aferição econômica possam voltar a ser princípio reitor na matéria.

A tentativa de demonstração da desvantagem alheia pode advir de uma argumentação relativa às condições econômicas, tantas vezes afastada por nossa jurisprudência como critério para a atribuição da guarda por se ter plena convicção de que as desvantagens

\footnotetext{
102 Permanece, no entanto, a possibilidade de imposição de sanção ao genitor, relativamente a condutas por ele praticadas e que tenham sido lesivas aos direitos de sua prole, diretamente considerada. Trata-se da suspensão ou da destituição do poder familiar, que serão decretadas em decorrência de "atos praticados intencionalmente pelos pais, ou por negligência ou omissão", garantido o contraditório. São exemplos de condutas reprováveis que autorizam a imposição da sanção direta: "casos de maus-tratos habituais ou abuso sexual, nos casos de rejeição manifesta ou evidenciada pela omissão dos deveres fundamentais e no uso ou exploração dos filhos para obter deles sustento ou vantagens de qualquer natureza". BECKER. In: CURY (Coord.). Estatuto..., cit., p. 116-117.
} 
econômicas existentes podem ser corrigidas com a determinação de pagamento de prestações de natureza alimentícia ${ }^{103}$, passando por posicionamentos conservadores e apegados a certo machismo, segundo os quais "a mulher, pela proximidade natural com a prole, advinda da intimidade com a gestação e pendores naturais decorrentes da condição feminina, estaria quase sempre em situação melhor para ter os filhos sob sua guarda em comparação com o homem" ${ }^{104}$, chegando até às discussões a respeito da vida e do comportamento sexual dos genitores, como promiscuidade ou homossexualidade, por exemplo.

Há que se diferenciar, pois homossexualidade por si só não é fator de piores condições para exercer a guarda dos filhos havidos por relação heterossexual, por adoção ou por inseminação artificial. Trata-se de opção relativa à vida sexual da pessoa humana, que pode ser exercida de forma privada, sem atingir terceiras pessoas e que, nessa condição, merece proteção do Estado ${ }^{105}$. Diversa é a situação do promíscuo, pai ou mãe, que mantém vida sexual desregrada, sujeitando ou podendo sujeitar a criança a situações constrangedoras, sejam elas de conotação heterossexual ou homossexual, uma vez que tais condutas podem configurar forma de exploração sexual, autorizando até mesmo a suspensão ou a destituição do exercício do poder familiar.

Parece, no entanto, que o critério legislativo determinado pelo novo Código Civil, não obstante representar real vantagem em relação ao critério do Estatuto da mulher casada e da Lei do divórcio, está longe de ser o melhor.

Os estudos psíquico-sociais indicam que a criança estabelece, ao longo de seu desenvolvimento natural, relações de dependência e complementaridade relativamente ao

\footnotetext{
${ }^{103}$ FONSECA. Modificação da guarda..., cit., p. 80. Ainda SELTZER, Judith A. Legal custody arrangements and children's economic welfare. AJS: American Journal of Sociology, Chicago, v. 96, n. 4, p. 895-929, 1991; também: STILERMAN. Menores..., cit., p. 127.

104 JORGE JUNIOR, Alberto Gosson. Guarda, tutela e adoção no Estatuto da Criança e do Adolescente: principais aspectos. Revista de Direito Privado, São Paulo, ano 2, v. 5, p. 24-71, 2001, p. 43. Sobre a figura do bom pai representada na lei por meio do desempenho da autoridade, do trabalho e da reconstrução da paternidade, veja-se COLLIER, Richard. Masculinity, law and the family. London and New York: Routledge, 1995, em especial p. 175-214.

105 REIS, Dagma Paulino dos. O homossexualismo e a discriminação do direito na vida social e familiar. Revista Jurídica, Porto Alegre, v. 47, n. 269, p. 14-18 (extrato do texto), 2000, p. 17-18; CUSTODIO, Gloria M. The discourse of discrimination: how lesbian mothers are judged in child custody disputes. Revista Jurídica de la Universidad de Puerto Rico, Rio Piedras, v. 63, n. 3, p. 531-550, 1994; RICHMAN, Kimberly. Lovers, legal strangers and parents: negotiating parental and sexual identity in family law. Law and Society Review, Denver, v. 36, n. 2, p. 285-291 (extrato do texto), 2002, p. 287-290, especialmente; CASABONA, Marcial Barreto. Guarda compartilhada. São Paulo: Quartier Latin, 2006, p. 125 (onde cita decisão do TJSP em que se decidiu que, dado o caráter provisório da guarda, era possível concedê-la a homossexual).
} 
mundo exterior. Nesse sentido, ganha extrema importância a assim chamada figura primária de referência, ou seja, a

"pessoa que predominantemente cuida dele [da criança] no dia-a-dia (da preparação e planeamento das refeições, do banho, da higiene e do vestuário, do transporte da criança para a casa de amigos ou para a escola, do acto de deitar a criança na cama a noite, de atender à criança a meio da noite, de a acordar de manhã, do ensino de boas maneiras, de regras de disciplina e da educação religiosa, moral, social e cultural etc.)"106.

Assim, a pessoa que tiver desempenhado esse papel teria a si a atribuição da guarda. Essa figura, portanto, depende antes de tudo do critério objetivo de se comprovar, por meio de prova retrospectiva de natureza notadamente testemunhal e de prova pericial ${ }^{107}$, qual dos pais desempenhou a figura primária de referência de forma mais consentânea com seu conteúdo. Além do mais, o critério é satisfatoriamente neutro na medida em que não faz referência ao sexo dos genitores, nem menção às incapacidades de qualquer um deles, nem mesmo por forma reflexa, mas cogita da atribuição da guarda em razão das atitudes e dos papéis desempenhados no transcurso da vida da criança, quando a relação triangular mostrava-se formada e sadia. Nos dizeres de Maria Clara Sottomayor:

"Constitui um critério neutro em relação ao sexo que permite ao pai obter a guarda dos filhos quando tenha sido a figura primária de referência destes, sem ter de provar a incapacidade da mãe; reduz a conflitualidade do processo e torna as decisões mais rápidas e com menores custos económicos e psicológicos. Encoraja os pais a chegarem a um acordo, diminui o número de litígios e evita que a ameaça de um conflito em torno da guarda dos filhos seja usada por um dos pais como meio de chantagem contra aquele que desempenhou o papel de figura primária de referência, para obter reduções na obrigação de alimentos ou outras vantagens económicas. A figura primária de referência promove a continuidade da educação e das relações afectivas da criança e constitui, também, em regra, aquele progenitor com quem a criança prefere viver. Dá-se, assim, uma convergência dos critérios que julgamos decisivos: as relações afectivas da criança com os pais, a continuidade do ambiente e

\footnotetext{
${ }^{106}$ SOTTOMAYOR. Divórcio, poder paternal..., cit., p. 165.

107 A respeito: BETTSCHART, Walter; FAVRE, Xavier. Direitos de guarda e de visita de filhos de pais separados ou divorciados: a peritagem pelo psiquiatra infantil. Infância e Juventude, Lisboa, n. 1, p. 9-29, 1991; CASTRO, Lídia Rosalina Folgueira. Disputa de guarda e visitas: no interesse dos pais ou dos filhos? São Paulo: Casa do Psicólogo, 2003; também o interessante trabalho de SHINE, Sidney. A espada de Salomão: a psicologia e a disputa de guarda de filhos. São Paulo: Casa do Psicólogo, 2003.
} 
a preferência da criança"108.

Todavia, se ambos os genitores tiverem desempenhado esse papel de modo satisfatório, sem que se possa decidir de forma cabal a quem entregar a guarda das crianças, e se eles não chegam a nenhum acordo quanto a isso, a autora citada faz referência a um critério supletivo, segundo o qual se deve ter em mente qual dos pais se mostra mais aberto a permitir o convívio do outro genitor com o filho ${ }^{109}$, qual o respeita mais enquanto pessoa humana que é e o utiliza menos como joguete nas discussões com o outro genitor ${ }^{110}$.

Nem se argumente que esse critério servirá para a dissimulação dos genitores, uma vez que, se o juiz se enganar a respeito, poderá, provocado pelo genitor visitante, rever a decisão primitiva em detrimento do guardião que impede, constantemente, a visitação dos filhos.

Concordando com a posição de Sottomayor, inclusive no que concerne ao critério supletivo adotado, deve-se, entretanto, adaptá-lo ao sistema brasileiro em um ponto. Não parece que esse critério supletivo possa servir para a atribuição da guarda a um ou a outro dos genitores. Ao contrário, sempre que ambos os pais desempenharem, conjuntamente, o papel de figuras primárias de referência para seus filhos, acredita-se que se trata de causa suficiente para a adoção do instituto a que a doutrina vem dando o nome de guarda compartilhada, atribuindo-se a ambos o papel de guardiões jurídicos ${ }^{111}$. O critério supletivo bastaria apenas para se fixar a atribuição da guarda física, ou seja, para se saber com qual dos genitores as crianças residiriam.

Pode ser, no entanto, que da análise dos fatos o juiz se convença que o melhor para a criança seja afastá-la de ambos os genitores, como medida excepcional. Nesse caso, o

\footnotetext{
${ }^{108}$ SOTTOMAYOR. Divórcio, poder paternal..., cit., p. 167.

${ }^{109}$ Não pude deixar de lembrar da interpretação que João Baptista Villela faz do julgamento de Salomão a respeito da verdadeira mãe: "Se se entender, ao contrário, que deveria ter a guarda aquela que excedesse em amor, tivesse ou não gerado, o critério [salomônico] é, então, perfeito. (...). Ouso, portanto, sustentar que o texto bíblico, na conhecida passagem, não nos dá nenhuma garantia de que a mãe atendida tenha sido a mãe biológica. Mas nos dá muito mais do que isso. Dá-nos uma admirável e simples lição de maternidade". VILLELA, João Baptista. Desbiologização da paternidade. Revista Forense, Rio de Janeiro, v. 271, p. 4551, 1980, p. 47-48.

110 SOTTOMAYOR. Divórcio, poder paternal..., cit., p. 168, nota 18. No mesmo sentido MARACCINNI, Eliane Michelini; MOTTA, Maria Antonieta Pisano. Guarda dos filhos: algumas diretrizes psicanalíticas. Revista dos Tribunais, São Paulo, v. 84, n. 716, p. 346-357, 1995, p. 354. Entendendo possível estender o critério de situação de risco também às crianças que sejam filhas de famílias desagregadas, já que possivelmente expostas ao risco da carência afetiva e educativa representada pelo afastamento do nãoguardião ou à situação de intermediários no conflito de seus pais, veja-se QUADRI, Assunto. Qualche considerazione sul rischio in età evolutiva. In: DELL'ANTONIO, Anna Maria (Org.). Minori a rischio e istituzioni. Milano: Giuffrè, p. 13-19, 1996, p. 13.

${ }^{111}$ Crítica a esse posicionamento doutrinário, infra, item 4 do presente capítulo.
} 
parágrafo quinto do art. 1.584 do Código Civil determina que o juiz possa deferir a guarda a terceira pessoa, desde que esta revele compatibilidade com a natureza da medida, ou seja, que se mostre apta a desempenhar os papéis de educador e de autoridade familiar que são tão necessários para o desenvolvimento moral e intelectual das crianças. $\mathrm{O}$ guardião escolhido pelo juiz, assim, deve ser pessoa apta a desempenhar as funções de figura primária de referência, muito embora seja claro que o afastamento dos pais da condição de titulares da guarda não implique suspensão ou destituição do poder familiar. Deve-se ter em mente que a razão verificada pelo juiz para conceder a guarda a um terceiro pode ser causa transitória, passageira ${ }^{112}$.

Para escolher essa pessoa, o juiz levará em consideração, ainda, o fato de o pretenso guardião manter com a criança uma relação verdadeira de afinidade e afetividade. Todavia, essa relação de afinidade e afetividade requerida pela lei deve ser prévia, ou seja, deve terse desenvolvido antes mesmo do problema de atribuição da guarda se tornar premente. É o caso, por exemplo, de uma babá, de um amigo da família, de uma irmã mais velha da criança desamparada, de seus avós.

Além disso, a lei recomenda ao juiz que considere o fato de a pessoa afetivamente afim à criança guardar com ela certo grau de parentesco. Dessa forma, entre uma babá e um avô, ambos afetivamente ligados à criança, deverá o magistrado preferir a nomeação do avô ${ }^{113}$. Mas o critério que conforma a norma, enquanto princípio, é a afetividade ${ }^{114}$. É ela que deve ser preferencial para o julgador, ainda que em detrimento do parentesco, em razão de a lei estar assentada na busca do melhor interesse da criança, motivo de ser da escolha da afetividade como aspecto principal a revelar a pessoa apta a desempenhar as funções de figura primária de referência.

No entanto, sempre que se invoca o princípio do melhor interesse da criança, é necessário redobrar os cuidados para o seu preenchimento. Já se afirmou que o princípio do melhor interesse da criança presta-se, muito facilmente, a aproximações

\footnotetext{
${ }^{112}$ LEROYER, Anne-Marie. L'enfant confié à un tiers: de l'autorité parentale à l'autorité familiale. Revue Trimestrielle de Droit Civil, Paris, v. 97, n. 3, p. 587-606, 1998, p. 590 e s.

113 CAMBI, Eduardo. Admissibilidade excepcional e condições para a concessão da guarda aos avós da criança ou do adolescente para atender situações peculiares (exegese do art. $33, \S 2^{\circ}$ do ECA). Revista de Direito Privado, São Paulo, ano 3, v. 12, p. 131-134, 2002, p. 132.

${ }^{114}$ Nesse sentido, nada obsta que a criança seja ouvida a fim de se fixar o seu guardião. Aliás, é de todo recomendável que isso ocorra, como já se teve a oportunidade de defender em outro trabalho: MONACO; CAMPOS. O direito de audição..., cit., p. 9-25; também, com muito interesse sobre esse tema: BONNARD, Jerome. La garde du mineur et son sentiment personnel. Revue Trimestrielle de Droit Civil, Paris, v. 90, n. 1, p. 49-67, 1991.
} 
tendenciosamente falsas, pois se confundem, também muito facilmente, as categorias interesse e direito da criança. Com efeito, o interesse teria perdido, ao longo do tempo, a sua função de orientação e de princípio de hermenêutica central (impresso já na Declaração dos Direitos da Criança de 1959), cedendo espaço para a categoria dos direitos das crianças, de conteúdo menos ambivalente e menos incerto ${ }^{115}$. Isso se deu na exata medida em que se tentou aproximar as categorias (interesse e direito) por meio da definição de direito subjetivo, enquanto interesse particularmente qualificado pela norma ${ }^{116}$.

Nesse sentido, no que sempre esteve inscrito como um princípio diretor da atividade legislativa, das políticas públicas e da atividade jurisdicional atinentes às crianças, procurou-se enxergar um verdadeiro direito subjetivo que pudesse ser, como todo direito subjetivo, exigido direta e coercitivamente.

O absurdo dessa aproximação fez com que se atribuísse ao princípio do interesse superior da criança um alcance que ele nunca possuiu e foi certamente responsável por uma série de abusos interpretativos que culminaram no reconhecimento da existência de uma nova forma de colocação das crianças perante suas responsabilidades e seus deveres (que, obviamente, devem mostrar-se condizentes com a sua situação de seres humanos em desenvolvimento), transformando-as em senhoras da situação.

Existe mesmo uma tendência mundial no sentido de se enxergar na criança um adulto em miniatura (adultomorfização), um ser que tudo pode e em função do qual o máximo deve ser feito como se esse (e só esse) fosse $\underline{o}$ seu melhor interesse ou $\underline{o}$ seu interesse primordial. Certamente isso acontece em razão de uma inegável culpa sentida pelos pais que, por imposições da vida moderna, afastam-se da educação de seus filhos, mantendo distância das questões mais importantes ao desenvolvimento destes, procurando recompensá-los com facilidades materiais ou com a concessão de excessiva liberdade.

Do ponto de vista objetivo, o princípio do melhor interesse da criança pode ser concebido como um dos princípios primordiais que devem ser considerados pelo Estado na definição de suas políticas públicas e não necessariamente como $\underline{o}$ princípio primordial $^{117}$.

115 Outros conceitos que devem ser apartados são os de "deseo del menor y el interés del menor (rectius: del niño)". Cf. STILERMAN. Menores..., cit., p. 71-72.

116 DOSI, Gianfranco. Dall'interesse ai diritti del minori: alcune riflessioni. Il Diritto di Famiglia e delle Persone, Milano, v. 24, n. 4, p. 1604-1627, 1995, p. 1604-1608.

${ }^{117}$ A crítica, feita por DOLINGER. A criança no direito..., cit., p. 89 e seguintes decorre da tradução oficial do $\mathrm{n}^{\circ} 1$ do art. $3^{\circ}$ da Convenção sobre os direitos da criança de 1989 para o português, tanto na versão brasileira (...devem considerar, primordialmente, o interesse maior da criança) como na versão portuguesa 
Outro problema relativo ao âmbito objetivo de aplicação do princípio foi o fato de se falar em interesse maior da criança, valendo-se de um critério quantitativo, logo refutado pela doutrina, que optou por um critério qualitativo, passando a designar o princípio como o do melhor interesse da criança, de conotação similar àquela que o princípio adquire em Portugal, onde é chamado de princípio do interesse superior da criança.

Do ponto de vista subjetivo, por sua vez, o princípio configura-se como uma prescrição dirigida ao Estado-legislador, que deve dele se valer em sua atividade legislativa, zelando para que a lei preveja, sempre, a melhor conseqüência para a criança, diante de duas ou três possibilidades que se apresentem ${ }^{118}$. Também como uma prescrição que se dirige ao Estado-juiz $^{119}$, que, em sua atividade de interpretação e aplicação das normas jurídicas, deve dar-lhe uma aplicação consentânea com as necessidades reais das crianças. Por fim, é também uma prescrição dirigida ao Estado-administrador, que, em sua atividade de concepção, implementação e execução de políticas públicas, deve tender a sua efetiva aplicação, optando, entre duas possibilidades, por aquela que se mostrar mais consentânea com o princípio. Também a família (nuclear ou alargada) deve se ater à observância do princípio para a tomada de qualquer decisão que diga respeito à criança, sem que com isso se confundam o princípio com o direito subjetivo que esteja sendo exercido.

(...terão primacialmente em conta o interesse superior da criança), quando comparada com a versão em inglês, língua oficial da ONU, vazada nos seguintes termos: "the best interests of the child shall be $a$ primary consideration".

${ }^{118}$ DOLINGER. A criança no direito..., cit., p. 90, dá o seguinte exemplo, aqui levemente adaptado: em qualquer situação de risco, se a lei determinar que a criança, em seu melhor interesse, deve ser a primeira a ser socorrida, isso pode implicar o seu efetivo socorro, mas a conseqüente impossibilidade de atendimento posterior, dada a falta de médicos e enfermeiros, atingidos pela mesma calamidade que atingira as crianças (essa era a regra da Declaração de 1924). Por outro lado, se a opção do legislador fosse efetivamente guiada pelo interesse superior da criança, ele teria determinado que, em situações de risco, a criança deve estar entre as primeiras a receber proteção e socorro, regra seguida pela Declaração dos Direitos da Criança de 1959.

119 Segundo COELHO, Bernardo Leôncio Moura. O bloco de constitucionalidade e a proteção à criança. Revista de Informação Legislativa, Brasília, n. 123, p. 259-266, 1994, p. 264-265, a jurisprudência brasileira vem densificando a doutrina da proteção integral da criança, elevando tal princípio a parte integrante do bloco de constitucionalidade. Segundo FRAGA, Thelma. A guarda e o direito à visitação sob $o$ prisma do afeto. Niterói: Ímpetus, 2005, p. 34, isso se deve ao fato de a Constituição Federal ter consagrado o princípio da dignidade da pessoa humana, o que acabou impondo a adoção do princípio do melhor interesse do menor (rectius: da criança). 


\section{CONSEQÜÊNCIAS DA ATRIBUIÇÃO DA GUARDA}

\subsection{Direito de visita}

O direito de visita configura-se como forma de exercício de um direito fundamental, reconhecido pela comunidade internacional e também pelo Estado brasileiro. Trata-se do direito à convivência diuturna da criança e do adolescente com seu núcleo familiar e com os membros da família alargada ${ }^{120}$. Além disso, é mecanismo de salvaguarda de outros direitos fundamentais, como o direito à saúde, em sua vertente mental, e o direito à dignidade $^{121}$.

Nesse sentido, se sua conformação toma a natureza de direito da criança decorrente de sua especial condição de sujeito em formação, correlativamente, constitui-se em dever dos pais e dos demais membros da família ${ }^{122}$. Tal afirmação não deve, contudo, ser interpretada em sentido restrito. Não é - apenas - um dever do pai, da mãe ou de membros da família alargada. Constitui-se também em direito que se lhes assiste. Assim, como ressalta Flávio Guimarães Lauria, "não há dúvida que é direito dos pais conviver adequadamente com seus filhos, mas, considerando a especial condição destes e a prioridade de seus interesses na hierarquia de valores constitucionalmente estabelecida, tal prerrogativa apresenta-se antes como um dever de sua parte para com o filho" ${ }^{, 123}$.

Seu exercício pode dar-se segundo um calendário rígido pré-fixado ou pode desenvolver-se de forma livre, conforme algumas regras abertas estabelecidas pelos

\footnotetext{
${ }^{120}$ TEIXEIRA. Direito de visita..., cit., p. 68, informa que "a possibilidade da convivência familiar entre avós e netos nasceu na França, decorrente de uma sentença da Corte de Cassação de 8 de julho de 1857", determinando a Corte que as visitas transcorressem no domicílio do genitor-guardião.

${ }^{121}$ LAURIA, Flávio Guimarães. A regulamentação de visitas e o princípio do melhor interesse da criança. 2. tir. Rio de Janeiro: Lumen Juris, 2003. p. 62.

${ }^{122}$ REZENDE, Joubert R. Direito à visita ou poder-dever de visitar: o princípio da afetividade como orientação dignificante no direito de família humanizado. Revista Brasileira de Direito de Família, Porto Alegre, ano 6, n. 28, p. 150-160, 2005, p. 157-159, diz tratar-se de obrigação de fazer infungível, porquanto personalíssima. O autor discute a possibilidade de se aplicar sanção específica ao parente devedor, atentando para o fato de ser medida extremamente perigosa, já que pode melindrar o futuro exercício de tal dever. Parece, assim, que razão assiste a LEITE DE CAMPOS. Lições..., cit., p. 139, quando afirma: "os direitos familiares (pessoais) não são direitos subjectivos no sentido estrito, ou seja, direitos de exigir de outrem um certo comportamento no interesse do credor. São, antes, poderes-deveres, poderes funcionais. O titular do poder não o exerce no seu interesse mas, antes, ('também') no interesse do «sujeito passivo»".

${ }^{123}$ LAURIA. A regulamentação..., cit., p. 60 (destaque do original).
} 
genitores e confirmadas em juízo por homologação judicial ${ }^{124}$. Em qualquer desses casos, quando há ambiente propício para a vivência de tal liberdade de visitação, é recomendável que regras mínimas sejam fixadas a fim de se preservar a privacidade do genitor-guardião, conforme já restou assentado anteriormente, em razão do estabelecimento da guarda compartilhada.

O ideal é que o regime de visitação espelhe a realidade vivenciada por genitores e prole antes do desfazimento dos vínculos de afeto outrora existentes entre aqueles. Daí se dizer que as visitas devam ocorrer, em tese, à imagem e semelhança do convívio familiar anterior $^{125}$, mantendo a relação triangular existente e que a ruptura da vida em comum do casal ameaça transtornar ${ }^{126}$. Na prática, entretanto, o que se assiste é a instauração de um litígio que decorre da impossibilidade fática de reprodução da convivência dentro dos padrões ordinários daquele grupo familiar que se desfaz, em razão da recalcitrância e do abuso perpetrados por quem detenha a guarda ou o direito de visitação, que extrapolam de seus direitos, diminuindo a convivência da prole com o outro. Tal comportamento anímico, carreado de rancores e mágoas decorrentes do desfazimento do casal ou ressurgidos em razão da reconstrução da vida afetiva por parte de um dos genitores, acaba acarretando a necessidade de "regulamentação das visitas por um terceiro, estranho às relações intersubjetivas das partes" ${ }^{, 27}$.

Percebe-se, assim, que o adimplemento do dever de visitação parece depender de dois aspectos que se inter-relacionam. Com efeito, se, de um lado, é necessário que haja a conscientização de que o filho precisa, para seu pleno desenvolvimento enquanto pessoa, da presença do genitor não-guardião durante os períodos de visita, também é imprescindível que o genitor-guardião não crie óbices para o bom desempenho desse dever. É cotidiano o posicionamento dos guardiões no sentido de impedir ou ao menos dificultar o acesso do outro genitor ao filho que lhes é comum ${ }^{128}$. Trata-se, no mais das vezes, do estabelecimento de rotina que acaba dificultando tal exercício, configurando forma de impedimento material para a visitação. Em inúmeras outras ocasiões, esse impedimento apresenta características de verdadeira barreira psicológica que se estabelece

\footnotetext{
${ }^{124}$ Segundo STILERMAN. Menores..., cit., p. 160, raramente o juiz fixa o sistema de visitação. Trata-se de seara em que, por mais litigiosa que se mostre a separação do casal, costuma haver acordo, uma vez fixada a guarda.

125 STILERMAN. Menores..., cit., p. 155.

${ }^{126}$ LAURIA. A regulamentação..., cit., p. 61.

${ }^{127}$ BOSCHI, Fábio Bauab. Direito de visita. São Paulo: Saraiva, 2005, p. 151-152.

${ }^{128}$ GOLDSTEIN. In: BELOFF, Derecho..., cit., p. 127.
} 
relativamente à figura do genitor não-guardião ${ }^{129}$. Os mecanismos podem ser os mais variados, mas o resultado a que visam é um só: incutir na criança ou no adolescente espécie de barreira mental que pode acarretar dificuldade de relacionamento com o genitor visitante, que se sente, ao final de um período mais ou menos longo - variável segundo a disposição e a estrutura psíquica dos envolvidos -, desmotivado para o contato necessário. Tal posicionamento diante das dificuldades passa a ser interpretado como abandono e dificulta, por vezes, qualquer tentativa futura de reaproximação.

De outra parte, a recusa contumaz ao exercício da visita por parte dos filhos, instigados ou não pelo guardião, bem como a possibilidade de sua retenção pelo visitador além do período previsto para a visita - quaisquer que sejam os motivos - podem ensejar o pedido de busca e apreensão das crianças, que serão retiradas, manu militari, da companhia de um dos genitores ou do terceiro-guardião e entregues ao outro genitor ou a outros membros da família que gozem do direito de visitação. Essa prática pode ser extremamente traumática para a criança e, no mais das vezes, reforça a identificação afetiva da criança com aquele que é forçado a lhe entregar às autoridades, para o estrito cumprimento do regime de visitação, chegando-se mesmo a afirmar que se trata de hipótese em que há espaço para o desenvolvimento da síndrome de Estocolmo, ou seja, da identificação afetiva entre "seqüestrado" e "seqüestrador"130.

Sim, porque não são apenas os pais que têm o direito e devem visitar os filhos que se encontram sob guarda do outro genitor. Como já se fez referência, esse direito se estende aos demais membros da família, como os avós, os tios. Tal extensão nasce com a doutrina, consagra-se na jurisprudência e, em alguns países, vem a ser positivada posteriormente ${ }^{131}$. Não é essa, todavia, a situação atual do direito brasileiro, que legislativamente reconhece o direito de visita apenas aos pais, silenciando a respeito de seu exercício pelos avós, por outros parentes e por terceiros afetivamente ligados às crianças e aos adolescentes envolvidos. Essa lacuna legislativa tem obrigado a doutrina e a jurisprudência a fundamentarem o direito de visitas por esses parentes na seara dos direitos da

\footnotetext{
${ }^{129}$ CASABONA. Guarda..., cit., p. 233-240, refere-se à síndrome da alienação parental.

130 MAKIANICH DE BASSET, Lidia N. Derecho de visitas: régimen jurídico del derecho y deber de adecuada comunicación entre padres e hijos. 1. reimp. Buenos Aires: Editorial Hammurabi, 1997, p. 189.

${ }^{131}$ BOSCHI. Direito..., cit., p. 66.
} 
personalidade ${ }^{132}$.

Em todos os casos, o local em que as visitas decorrerão apresenta-se como fator de suma importância, capaz de influir na forma como são mantidos os laços de parentalidade ou parentesco entre a criança e o visitante. Assim, a manutenção das visitas na residência do guardião, não obstante ter sido a forma mais usual de convívio no passado e a que acabou por dar nome ao instituto, foi sendo a pouco e pouco substituída pela liberdade, concedida ao visitante, de ter consigo o seu filho ou parente em sua própria residência, já que se constatou que a manutenção do convívio em território do guardião, muitas vezes, inibia a mais ampla afetividade possível, intimidando visitante e visitado, especialmente quando as relações entre os genitores fossem traumáticas ou mal resolvidas. Essa forma de exercício da visitação implicava, então, a convivência forçosa de pessoas que, entre si, não mantinham sequer relações de cordialidade, o que acabava refletindo negativamente na relação que se pretendia conservar, ou seja, na relação entre visitante e visitado.

Daí por que, aos poucos, se foi admitindo que as visitas se travassem na residência do visitante, que apanhava o filho ou parente na morada do guardião, levando a criança até sua residência, território em que estavam desprovidos da vigilância do guardião, e onde estreitavam os precedentes laços de afeto. Logo se objetou que o traslado da criança à residência do visitante podia expô-la à existência de terceira pessoa, com quem não mantinha qualquer relação de afetividade ${ }^{133}$. No entanto, deve-se atentar para o fato de que a nova companhia de seu genitor, quando da reconstrução da vida afetiva deste pela constituição de nova entidade familiar, institui entre a criança e seu padrasto ou madrasta parentesco por afinidade em linha reta que, ademais, é vínculo indissolúvel segundo o sistema brasileiro. Então parece que, antes de representar entrave à convivência do visitante e do visitado, deva tal realidade ser encarada como saudável e desejosa, já que representa a efetiva ruptura da relação entre o pai e a mãe da criança, incutindo nesta a certeza de que a vida deve continuar. Assim, não parece ser procedente a idéia de que a existência de outra pessoa na residência do visitante, estranha à família originária, deva ser óbice para que as visitas, na normalidade dos casos, decorram naquele local. Claro está, portanto, que somente situações anormais, como os maus-tratos, a exposição da criança a violência física, mental ou mesmo sexual, poderão ser invocadas para o estabelecimento de

\footnotetext{
${ }^{132}$ Nesse sentido: BOSCHI. Direito..., cit., p. 66 e s.; TEIXEIRA. Direito de visita..., cit.; NERY JUNIOR, Nelson; MACHADO, Martha de Toledo. O estatuto da criança e do adolescente e o novo Código Civil à luz da Constituição Federal. Revista de Direito Privado, São Paulo, ano 3, v. 12, p. 9-49, 2002, p. 17 e s.

${ }^{133}$ MAKIANICH DE BASSET. Derecho de visitas..., cit., p. 110-111.
} 
visitas em locais públicos e sob supervisão profissional ${ }^{134}$.

No que concerne ao direito de visita quando há modificação do domicílio ou da residência habitual de um dos genitores, seu exercício pode complicar-se ainda mais, pois é necessário garantir - no mais das vezes e salvo situações excepcionais de abuso, maustratos ou mesmo abandono material ou intelectual ${ }^{135}$ - o direito de visita da mesma forma que ocorre em casos em que ambos os genitores permanecem no mesmo território. É bem verdade que a disposição e a longa extensão geográficas brasileiras podem acarretar o afastamento entre pais e filhos e a necessidade de que o direito-dever de visitas seja concentrado em períodos longos (por exemplo, o período de férias escolares), mas, nesse caso, porquanto se esteja a tratar de visitas em um mesmo território nacional soberano, as dificuldades podem ser solucionadas segundo o próprio direito brasileiro.

Esse direito assume, nas relações plurilocalizadas, uma feição toda particular na medida em que o direito de visita há de se fazer com a deslocação de um dos visitantes/visitados quer seja o genitor, quer seja o filho - ao exterior. Por si só, esse direito esbarra já no problema relativo à saída da criança de seu território nacional, uma vez que a segurança indique certa preocupação com o fito de evitar os casos de tráfico internacional de crianças. E é justamente nesse domínio que o direito de visita ganha contornos os mais trágicos e de difícil resolução. Com efeito, quando a criança vai ao exterior, deixando o Estado de sua residência habitual para visitar seu ascendente, este pode retê-la ilicitamente, impedindo seu retorno quando terminado o período da visitação. Por outro lado, se é o pai ou a mãe que se desloca até o Estado de residência habitual do filho, o problema, então, é o de se redobrarem os cuidados para que a criança não consiga deixar o país, acompanhada do genitor, configurando-se, nesse caso, o seqüestro ou o rapto em sua forma de subtração $^{136}$, além de ser problemática a garantia de que o genitor conseguirá adentrar o

\footnotetext{
134 Trata-se da chamada visita no fórum. Cf. BOSCHI. Direito..., cit., p. 188.

135 LEITE, Eduardo de Oliveira. Le droit (non sacré) de visite. In POUSSON-PETIT, Jacqueline (Org.). Liber Amicorum Marie-Thérèse Meulders-Klein: droit comparé des personnes et de la famille. Bruxelles: Bruylant, p. 161-179, 1998, p. 164.

${ }^{136}$ Para as convenções internacionais de proteção da criança, rapto ou seqüestro são expressões similares e que se referem à subtração da criança por um de seus genitores, sem autorização para tanto (Convenção da Haia concernente à competência, lei aplicável, reconhecimento, execução e cooperação em matéria de responsabilidade parental e de medidas de proteção às crianças). Cf. dados estatísticos em GRÜNSPUN, Haim. A guarda dos filhos e o melhor interesse da criança. Revista do Advogado, São Paulo, n. 25, p. 8389, maio 1988, p. 88-89. Por outro lado, a subtração de crianças para fins ilícitos (como trabalho forçado, prostituição, extirpação de órgãos) por terceiras pessoas é designada pela expressão tráfico de menores (rectius: de crianças) (Convenção interamericana sobre tráfico internacional de menores, de 1994 - CIDIPV). A esse respeito: SHECAIRA, Sérgio Salomão; SILVEIRA, Renato de Mello Jorge. O tráfico
} 
território do Estado em que a criança é residente, mormente quando se fizer necessária a atribuição de visto de entrada, em razão do grau de relações diplomáticas havidas entre os Estados envolvidos.

Seja como for, e sendo o direito de visita um corolário do direito de convivência familiar, não se pode privar a criança desse direito pelo simples temor de que o rapto ou o seqüestro venham a se configurar. Bem por isso, o exercício do direito de visita em casos internacionais será uma preocupação constante ao longo deste trabalho.

\subsection{Alimentos}

O legislador civil brasileiro estatuiu, assim no casamento como na união estável, o dever de guarda, sustento e educação dos filhos menores. Em que pese a possibilidade de se criticar a colocação tópica em que essa regra está esculpida, ou seja, no âmbito dos deveres recíprocos entre os cônjuges e os companheiros, forçoso é convir que a disposição acarreta uma dualidade de sistemas conforme viva a criança em companhia de ambos os pais (casados ou unidos estavelmente) ou na companhia de apenas um deles, sendo o outro genitor vivo, mas separado do guardião. O dever de sustento, assim estruturado pelo legislador, não se confunde, portanto, com o dever de prestar alimentos. Dever de sustento é dever compartilhado por ambos os genitores, enquanto perdurar o casamento ou a união estável. A partir do momento em que é dissolvida a sociedade conjugal, rompido o vínculo matrimonial ou dissolvida a união estável, o dever de sustento transmuda sua natureza jurídica e especializa-se relativamente ao genitor não-guardião, que assume a obrigação de arcar com parte das despesas relacionadas à criança, na proporção de seus recursos. Daí falar-se que o dever de prestar alimentos tem natureza jurídica de caráter patrimonial sui generis.

\footnotetext{
"Trata-se de um direito com conteúdo patrimonial e finalidade pessoal, uma vez que resta configurada uma relação patrimonial de crédito-débito, na qual o credor pode exigir uma prestação, onde não haja interesse econômico, por parte do alimentando, tampouco auxílio que lhe aumente o patrimônio" ${ }^{\text {"137. }}$.
}

\footnotetext{
Internacional de Mulheres e Crianças. Boletim do Instituto Brasileiro de Ciências Criminais, São Paulo, ano 10, n. 112, p. 3-4, 2002. Veja-se, infra, o capítulo IV.

${ }^{137}$ FACHIN, Rosana Amara Girardi. Dever alimentar para um novo direito de família. Rio de Janeiro: Renovar, 2005, p. 36-37.
} 
Ou seja, o que está em jogo não é o incremento patrimonial do filho alimentando, mas tão-só a manutenção de sua vida, de seus hábitos de consumo, a satisfação de suas necessidades, procurando-se, mais uma vez, garantir certa continuidade das relações travadas pela criança, tal qual na situação anterior, ou seja, quando seus pais conviviam.

Bem por isso, Carlos Alberto Ghersi procura demonstrar que as necessidades dos filhos costumam aumentar conforme o avanço de sua estrutura cronológico-antropológica, que desencadeia uma necessidade mais premente relativamente ao consumo sociocultural ${ }^{138}$.

O quantum da prestação alimentar é obtido segundo uma equação casuística que leva em consideração, de um lado, as necessidades do alimentando e, de outro, as condições do alimentante. É o mesmo autor argentino quem sistematiza a matéria de acordo com condições próprias à pessoa dos filhos, dividindo-os em absolutamente incapazes, relativamente incapazes, incapazes emancipados e plenamente capazes por implemento de idade $^{139}$. Faz isso por meio da indicação dos bens e das necessidades que devem ser suportados pelos pais, a fim de se poder proceder a sua quantificação em termos econômicos.

Ghersi afirma que um dos primeiros bens que devem ser suportados pelos genitores conjuntamente na constância do casamento ou da união estável, e na proporção de suas condições na hipótese de separação em sentido amplo, é a concessão de um lar, enquanto espaço destinado à habitação dos filhos para que estes possam crescer protegidos e seguros e receber educação informal diretamente de seus pais ou de seu guardião. Há que se atentar para a localização sociogeográfica da habitação, já que a residência deve fixar-se em local compatível com a condição social da família, sob pena de, não se garantindo esse fator, expor-se a criança a um processo de socialização deficiente ou mesmo de dessocialização ${ }^{140}$.

O dever de sustento ou os alimentos devidos às crianças devem também ser capazes de garantir sua alimentação e vestimenta - alimentação que deve ser entendida, aqui, não só como o fornecimento de alimentos, mas principalmente, como alimentação nutritiva e

\footnotetext{
${ }^{138}$ GHERSI, Carlos Alberto. Cuantificación económica de los alimentos. Buenos Aires: Astrea, 2000, p. 175, letra "g".

139 A nomenclatura utilizada pelo autor, própria ao sistema argentino, foi aqui adaptada à realidade do sistema nacional. O autor menciona "menores impúberes", "menores púberes sin emancipación", "menores púberes con emancipación", e "mayores de edad". GHERSI. Cuantificación..., cit., p. 61-87.

${ }^{140}$ GHERSI. Cuantificación..., cit., p. 67-68.
} 
balanceada. Segundo o mesmo autor, a vestimenta devida aos filhos deve ser condizente com sua classe social, sob pena de se lhes impingir uma dificultosa sensação de pertinência social $^{141}$.

Também se deve incluir, no cômputo da prestação alimentícia devida, o quantum necessário para a satisfação das condições de saúde, de atendimento médico e infraestrutura sanitária, como forma de se garantir, preventiva e prospectivamente, o pleno direito à saúde ${ }^{142}$.

Por fim, compõem a noção do que é devido aos filhos pelos pais, a prestação da cultura e educação informais, além do ensino formal nos níveis fundamental e médio ${ }^{143}$.

A satisfação desses recursos que compõem a noção mais larga de alimentos devidos, bem como a noção de dever de sustento, prescindem, assim, de qualquer espécie de comprovação. Os alimentos são devidos pelo fato de a criança e o adolescente não possuírem capacidade suficiente para a sua obtenção. No entanto, a pertinência da família a determinado estrato social e a disparidade de condições econômicas e sociais vivenciadas em nossa sociedade autorizam que se busque complementar "um projeto cultural amplo conforme à classe social a que se pertença, tendo-se em conta os meios de inserção cultural e laboral da criança" ${ }^{\prime 44}$. Quer isso significar que, sempre que as condições econômicas dos pais permitirem, devem os alimentos ser fixados em patamar mais elevado, servindo a verba extra não para o enriquecimento da criança, posto que incompatível com a natureza da medida ${ }^{145}$, mas, sim, para a satisfação de necessidades outras, como cursos extracurriculares, sempre se tendo em vista o aperfeiçoamento cultural da criança, que lhe proporcionará melhores condições de inserção no mercado de trabalho.

$\mathrm{Na}$ hipótese de crianças que vivam na companhia de um dos genitores apenas, pode-se assistir a certa relativização do binômio capacidade-necessidade. Com efeito, se, diante das necessidades da criança, o genitor a quem incumbe prestar auxílio material com vistas a seu pleno desenvolvimento não dispuser de condições para disponibilizar o valor considerado necessário para suprir as necessidades básicas do infante, abre a lei a

\footnotetext{
${ }^{141}$ GHERSI. Cuantificación..., cit., p. 70.

${ }^{142}$ GHERSI. Cuantificación..., cit., p. 72.

${ }^{143}$ GHERSI. Cuantificación..., cit., p. 73-74.

${ }^{144}$ GHERSI. Cuantificación..., cit., p. 84. Em seguida, afirma o autor, p. 85: "En síntesis, el proyecto debe ser lo más ambicioso posible y responder a la lógica capitalista que tiene como objetivo la maximización del beneficio de la inversión".

${ }^{145}$ FACHIN. Dever alimentar..., cit., p. 36-37.
} 
possibilidade de que outros parentes mais remotos sejam convocados a prestar, de forma concorrente, parte da parcela fixada.

No caso de impossibilidade absoluta do genitor, podem os alimentos ser pleiteados em face dos demais ascendentes, havendo preferência pelo parentesco de menor grau. Assim, se o pai que deveria prestar alimentos encontrar-se desempregado e sem fonte de renda, poderá a criança pleitear, por meio de seu representante legal, os alimentos devidos em face de seus avós ${ }^{146}$.

\subsection{Administração dos bens de filhos menores}

O sistema jurídico nacional é explícito ao deferir o direito de administração dos bens dos filhos menores a ambos os genitores, enquanto durar o poder familiar ${ }^{147}$, salvo na hipótese de tais bens terem sido objeto da herança do avô, recebida pelas crianças, em representação ao genitor deserdado ou indigno, hipótese em que o filho ou a filha do autor da herança serão alijados de tal administração, que incumbirá, exclusivamente, ao genro ou à nora do falecido, na hipótese de terem sido os bens deixados ou doados aos filhos, com cláusula expressa de não se submeterem à administração de seus pais. Também estarão excluídos os valores auferidos em decorrência do trabalho do maior de 16 anos, bem como os bens que tenham sido, com esses valores, adquiridos. Por outro lado, caberá exclusivamente à mãe a administração dos bens adquiridos em favor de filho extraconjugal, antes de efetivado o reconhecimento da paternidade pelo pai. Todavia, se o reconhecimento se tiver dado em momento anterior ao da aquisição, serão os bens atribuídos à administração de ambos os genitores, conjuntamente.

Percebe-se, assim, que a separação, o divórcio ou a dissolução da união estável não implicam perda do direito de participar da administração dos bens dos filhos, mesmo que o genitor seja afastado da guarda de sua prole. Esse direito decorre, portanto, do exercício do poder familiar e deve ser exercido como conseqüência da autoridade parental.

\footnotetext{
${ }^{146}$ Essa obrigação que incumbe aos avós em primeira chamada é, por isso, dita obrigação subsidiária. TEIXEIRA. Direito de visita..., cit., p. 70.

${ }^{147}$ PEREIRA. Divórcio e..., cit., p. 184. Em perspectiva histórica que não se limita aos filhos menores de idade, veja-se MARLASCA MARTÍNEZ, Olga. Capacidad patrimonial de los hijos que están bajo la potestas del padre. In: LÓPEZ-ROSA, Ramón; PINO-TOSCANO (Org.). El derecho de familia...cit., p. 407-421.
} 


\section{EXERCÍCIO DO PODER FAMILIAR NA DESUNIÃO DAS FAMÍLIAS}

Ana Carolina Brochado Teixeira enxergou, com percuciência, a confusão conceitual ocorrida em razão das possíveis imbricações dos conceitos de guarda e autoridade familiar, afirmando, com razão, que "geralmente, atribui-se maior importância à guarda do que ela realmente tem, mesmo porque não se discutem ou não se definem de forma correta a essência e os limites do poder familiar,"148.

O que a autora propõe, em verdade, é a valorização da real consciência de manutenção de ambos os genitores nas atribuições que decorrem do poder familiar, mesmo após a dissolução de sua vida em comum, propugnando que ambos valorizem a sua parentalidade de forma a se manterem presentes e participativos na condução da vida da prole ${ }^{149}$, enquanto pendente o seu estágio formativo, quando ela é de suma importância. Parece assistir razão à autora. Com efeito, a separação, o divórcio ou a dissolução da união estável, que põem fim ao relacionamento entre os genitores da criança, ou a situação de nunca se ter estabelecido entre os genitores qualquer espécie de relação juridicamente tutelada, como é o caso de filhos de pais solteiros e que assim se mantêm, por opção lícita e responsável (saliente-se) após a gravidez, não impedem que a autoridade parental seja a eles investida por lei, já que o poder familiar decorre, simplesmente, do fato jurídico da filiação ${ }^{150}$.

Dessa forma, segundo o pensamento da autora, o exercício da guarda por sua modalidade simples, alternada ou conjunta parece ser totalmente irrelevante, já que em qualquer delas, mantida intacta a autoridade parental relativamente a ambos os genitores, como decorrência própria da titularidade do poder familiar que não se alterou pela ruptura do casal conjugal, os pais participarão, em idêntica medida, da condução da vida da prole. Nesse sentido, Ana Carolina Brochado Teixeira informa que a mens legis não é - e nunca foi - a de propalar um desequilíbrio entre os poderes da autoridade parental, concentrando-

\footnotetext{
148 TEIXEIRA, Ana Carolina Brochado. Família, guarda e autoridade parental. Rio de Janeiro: Renovar, 2005 , p. 105.

149 TEIXEIRA. Família, guarda..., cit., p. 105-110.

${ }^{150}$ Tanto assim que a paternidade oculta pode ser investigada e reconhecida pelo juiz, independentemente da vontade do pai biológico.
} 
os no instituto da guarda ${ }^{151}$, como sempre se afirmou na doutrina nacional.

Como já se adiantou anteriormente, parece que tal raciocínio é seguido em Portugal, onde se afirma que a guarda dos filhos deve ser atribuída sempre a um dos progenitores, a terceira pessoa ou a estabelecimento de (re)educação ou assistência (Estado), "porque dos dois [pai e mãe] não pode ser" ${ }^{, 152}$. Admite-se, no entanto, que os pais podem acordar a respeito do exercício do poder paternal, estabelecendo que ele seja exercido "em comum dos dois, decidindo as questões relativas à vida do filho em condições idênticas às que vigoravam para esse efeito na constância do matrimónio"153. Assim, ao que parece, é lícito afirmar que os portugueses referem-se à guarda tão-só no sentido de guarda física, ao passo que aquilo a que se chama, no Brasil, de guarda jurídica é lá chamado de poder paternal.

Assim é que as relações entre pais e filhos permanecem íntegras após o desfazimento do casal conjugal, mantendo ambos os genitores a incumbência de sustentar os filhos menores, a possibilidade de negar ou de conceder a autorização para que tais filhos convolem núpcias, pendente sua incapacidade matrimonial, bem como o direito conjunto de representação judicial dos incapazes e a prerrogativa de nomear tutor, em testamento, impossibilitado o ascendente sobrevivo do infante de permanecer no exercício do poder familiar. Há que se ressaltar, no entanto, que algumas vezes é imprescindível que se estabeleça uma ordem preferencial para o exercício desses direitos e deveres. Assim, no que concerne ao direito de representação judicial, a preferência deve ser dada ao guardião, mas nada obsta que o não-guardião exerça tal mister estando o primeiro impossibilitado ou, ainda, na hipótese de haver manifesta colidência de interesses entre guardião e filho.

${ }^{151}$ TEIXEIRA. Família, guarda..., cit., p. 106.

${ }^{152}$ SANTOS. Direito da..., cit., p. 539.

${ }^{153}$ SANTOS. Direito da..., cit., p. 539. 


\title{
DIREITO INTERNACIONAL PRIVADO E GUARDA DE FILHOS: METODOLOGIA, JUSTIÇA E PERMEABILIDADE A VALORES
}

\author{
SUMÁRIO: 1. Estrutura da norma, método do direito internacional privado e preocupação \\ com o direito substancial: análise teórica aplicada às relações familiares: 1.1. Normativismo, \\ classicismo e segurança jurídica; 1.2. Flexibilidade e tentativa de realização de justiça por \\ meio da aplicação das normas de direito internacional privado - 2. Conteúdo da relação \\ familiar e reflexos na concepção do método do direito internacional privado: tomada de \\ posição teórica e pragmática.
}

\section{ESTRUTURA DA NORMA, MÉTODO DO DIREITO INTERNACIONAL PRIVADO E PREOCUPAÇÃO COM O DIREITO SUBSTANCIAL: ANÁLISE TEÓRICA APLICADA ÀS RELAÇÕES FAMILIARES}

Léo Raape, nos idos de 1934, ministrou curso na Academia de Direito Internacional da Haia sobre as relações jurídicas entre pais e filhos, enfocando notadamente o problema da legitimação dos filhos naturais ${ }^{154}$. Sua intenção foi a de demonstrar que muitos dos antigos e dos novos problemas fundamentais ao direito internacional privado poderiam ter como ponto de partida para sua explicação sistemática aquele tipo de relação jurídica.

$\mathrm{O}$ avanço de uma série de fatores sociais e as revoluções culturais por que passou o mundo nas últimas décadas do século XX refletiram de forma assoladora na constituição da família. Seu conceito deixou de ser entendido, ao menos nos países ocidentais, em função da relação de prevalência dos pais em face dos filhos ou do marido em face da mulher. A família patriarcal, como visto no capítulo precedente, perdeu espaço em razão das alterações dos valores sociais e em seu lugar surgiu nova estrutura familiar chamada eudemonista, em que o grupo familiar passa a ser encarado como o locus privilegiado para

\footnotetext{
${ }^{154}$ RAAPE, Léo. Les rapports juridiques entre parents et enfants comme point de départ d'une explication pratique d'anciens et de nouveaux problèmes fondamentaux du droit international privé. Recueil des Cours, Paris, v. 50, p. 402-544, 1934.
} 
a realização pessoal de cada um dos indivíduos que a compõem, o que se faz em razão de um desiderato comum que se consubstancia na funcionalidade que tal família passa a exercer. A família passa a ser, então, um instrumento de realização de cada indivíduo em particular. Já não é mais o indivíduo que existe em função e para a família, mas é a família que passa a existir em função e para a realização pessoal do indivíduo ${ }^{155}$.

Tal mudança se reflete na visão que a comunidade internacional tem da família e na dicotomia essencial que a cerca, ou seja, na visão que dela atualmente se tem no sentido de constituir uma associação coesa de pessoas autônomas (eudemonismo), ao mesmo tempo em que continua a ser encarada como um grupo de indivíduos que deve necessariamente submeter-se a regras, mormente as de estrutura. Tal dicotomia essencial acaba por se refletir na proteção jurídica que o direito internacional procura a ela dispensar.

"Althought international treaty law salutes the family as the basic unit upon which society is organised the family is a concept in transitional development. There is an essential dichotomy surrounding the family: it is conceptualised both as a cohesive association of autonomous people and as a group of individuals subject to a higher law which protects competing claims. Unlike the definition of child international law lacks a treaty definition of family and it would be too simplistic to conclude that part of the problem is that there is no Convention on the Rights of the Family. The fundamental issue of definition would still have to be resolved"156.

As relações interpessoais ganham, assim, dinâmica própria, caracterizada pela multiplicidade de fatores correlacionados presentes nas mais diversas formas de relacionamento jurídico. Diante de tal realidade social complexa, as normas clássicas de direito internacional privado que normalmente são redigidas segundo um grau de abstração e generalidade que não se pode negligenciar, parecem não se coadunar mais com a estruturação familiar vivenciada na medida em que, hodiernamente, a origem nacional ou os locais de domicílio ou residência habitual dos membros da família podem não coincidir e os antigos critérios de prevalência da lei do marido ou do pai perderam, no mais das vezes, sua razão de ser. Consequiência dessa constatação é a descoberta de lacunas no sistema que exigem do intérprete do direito internacional privado uma submissão mais ou menos rigorosa ao esquema de regras e exceções, exigindo - por vezes - extensa atividade

\footnotetext{
155 JAYME. Diritto di famiglia..., cit., p. 295-304.

156 BUEREN, Geraldine van. The international law on the rights of the child. The Hague/Boston/London: Martinus Nijhoff Publishers, 1998, p. 68.
} 
criativa $^{157}$ na construção de normas aptas a emprestar dinamismo e pertinência à resolução dos conflitos de lei no espaço.

Assim, verificada a qualificação que o sistema jurídico brasileiro atualmente dá ao instituto da guarda e àqueles que lhe são correlatos, percebe-se que o que se busca é justamente garantir à criança condições de se desenvolver e de desenvolver sua personalidade segundo os paradigmas desta família eudemonista. Aliás, saliente-se, o avanço experimentado pelos institutos que compõem o objeto de análise desta tese no sistema brasileiro decorrem da implementação, no plano interno, de valores que nascem e se cristalizam no plano internacional relativamente aos direitos da criança.

Como salienta Alegría Borrás,

"En un mundo cada vez más internacionalizado, ya no es suficiente que las normas materiales internas regulen de forma minuciosa una determinada institución protectora del menor (rectius: del niño), acompañada de alguna norma, más o menos detallada, de derecho internacional privado. La diferente nacionalidad o residencia del menor (rectius: del niño) respecto a sus padres por naturaleza (...), etc., son ejemplos claros de supuestos en los que la internacionalidad de la situación debe recibir una respuesta del derecho internacional privado, autónomo o convencional, ya que la normativa material resulta inoperante si no va acompañada de este tipo de regulación" ${ }^{\prime 158}$.

Nesse sentido, o que se busca investigar é o grau de aptidão que o direito internacional privado tem para garantir que a lei material a ser afinal aplicada para a resolução das questões que surgem por ocasião da separação dos genitores com reflexos extrafronteiriços será uma lei que possa espelhar, minimamente, essa nova tendência de valorização da família - e das relações que em seu âmbito se travam - enquanto locus apropriado para o desenvolvimento da pessoa humana dos filhos e de sua individualidade, tudo concatenado com a necessidade maior de se garantir o respeito aos direitos humanos fundamentais da pessoa em desenvolvimento.

Como salienta Fausto Pocar, a proteção garantida às crianças não lhes é devida em razão da relação jurídica que entre elas e seus genitores pré-existe, mas, antes disso, é-lhes

\footnotetext{
157 Assim: SÁNCHEZ LORENZO, Sixto A. Postmodernismo y derecho internacional privado. Revista Española de Derecho Internacional, Madrid, v. 46, n. 2, p. 557-585, 1994, p. 581.

158 BORRÁS RODRÍGUEZ, Alegria. El "interes del menor" como factor de progreso y unificación del derecho internacional privado (discurs d'ingres). Revista Juridica de Catalunya, Barcelona, v. 93. n. 4. p. 915-967. 1994, p. 924.
} 
garantida pela comunidade internacional por considerá-los destinatários de uma exigência protetora $^{159}$ que se opõe em face de toda a coletividade ou em face de um grupo restrito de pessoas - como os membros da família - mas nunca em função das relações jurídicas preexistente entre as partes - como as relações de parentesco ou tutela ${ }^{160}$. Trata-se de hipótese de aplicação do princípio do melhor interesse da criança que, no campo do direito internacional privado, comporta "la adopción de soluciones flexibles y disposiciones materialmente orientadas" 161 .

Indaga-se, portanto, acerca de eventual abertura do direito internacional privado para garantir a aplicabilidade de uma lei material que se mostra adaptada aos resultados que o sistema internacional quer e deve desenvolver por impositivo de suas próprias normas. Não o resultado individual e concreto - se a criança permanecerá sob a guarda do pai ou da mãe (refletindo uma visão patriarcal); se restará sob a guarda do nacional ou do estrangeiro (refletindo uma visão nacionalista); se será mantida em território nacional ou se será levada ao exterior (refletindo a visão territorialista e paternalista do Estado que se considera o único ente internacional apto a proteger aqueles que até então se encontravam sob sua jurisdição ${ }^{162}$ ) - mas antes o resultado geral e abstrato que se considera o mais importante se ficará sob a guarda ou jurisdição daquele (genitor, Estado, sistema) que melhor puder garantir um ambiente saudável e hábil para o desenvolvimento da criança enquanto pessoa humana capaz de lidar com a realidade atual, cada vez mais multi-facetária, multilocalizada, multi-cultural ${ }^{163}$. Resultado geral e abstrato este que demonstra "a dignidade da

${ }^{159}$ DOLINGER, Jacob. Contratos e obrigações no direito internacional privado. São Paulo/Rio de Janeiro: Renovar, 2007, p. 545 menciona "que a lei mais próxima à parte que queremos proteger é a indicada pelo princípio da proteção".

160 POCAR, Fausto. La protection de la partie faible en droit international privé. Recueil des Cours, Dordrecht/Boston/Lancaster, v. 188, p. 339-417, 1984, p. 351.

${ }^{161}$ BORRÁS RODRÍGUEZ. El "interes del menor"..., cit., p. 923.

${ }^{162}$ Idéia essa muito difundida nos primórdios da disciplina e que Pasquale Stanislao Mancini foi o primeiro a enfrentar, pregando a necessidade de se aplicar a lei nacional para reger as situações pessoais atinentes ao indivíduo. Veja-se, a esse respeito, BATIFFOL, Henri. Aspects philosophiques du droit international privé. Paris: Dalloz, 2002 (fac-símile da edição de 1956), p. 197, quando afirma que Mancini "en déduit que la loi nationale de chaque personne a la compétence de principe pour régir toutes les relations concernant cette personne; la tendance séculaire au territorialisme, qu'il est le premier à attaquer de front, procede, selon lui, de l'idée superficielle que le légisateur régit essentiellement les choses, pour en déduire que la compétence primordiale est celle de la loi de la situation des biens".

163 AMARAL JUNIOR, Alberto do. Entre ordem e desordem: o direito internacional em face da multiplicidade de culturas. In: BAPTISTA, Luiz Olavo; FONSECA, José Roberto Franco da. $O$ direito internacional no terceiro milênio: estudos em homenagem a Vicente Marotta Rangel. São Paulo: LTr, p. $152-165,1998$, p. 152, considera como causas para a perplexidade que o mundo contemporâneo tem gerado quanto aos mecanismos regulatórios internacionais, dentre outros, "a emergência de novos e intensos conflitos entre os sistemas sócioculturais" e "o crescimento do fenômeno transnacional ilustrado pela proliferação das interações transfronteiriças envolvendo membros de [diversas] agremiações", dentre as quais poder-se-ia incluir a família. 
diferença, a compreensão da diversidade, o respeito pelo desconhecido, a tolerância pelo estranho" "164, em suma, "o reconhecimento de que não existe direito absoluto, assim como não existe verdade absoluta" $" 165$.

Não, também, o próprio resultado material em si (justiça material), mas o resultado que as normas de direito internacional privado podem e devem garantir e que se pode representar pela aplicação, no caso concreto, da lei - nacional ou estrangeira - que se mostra a mais próxima para a resolução do litígio, garantindo, assim, maior adequação, sem descurar, em absoluto, a necessidade de proteção que vise evitar a aplicação de leis materiais que podem acarretar resultados injustos (justiça conflitual) ${ }^{166}$. Deve-se sublinhar, portanto, a necessidade de certa independência de critérios para a escolha da lei aplicável e para a regulação material do assunto ${ }^{167}$. Como salienta Fausto Pocar:

"le contenu du droit étranger désigné par la règle de conflit ne devrait jouer aucun rôle lorsque le choix est effectué. La fonction du droit international privé devrait être distinguée d'une manière rigoureuse de celle du droit matériel: tandis que ce dernier doit fournir la solution concrète du cas d'espèce, le droit international privé se limite à indiquer d'après quel système de droit le juge doit trouver la solution" ${ }^{\text {168 }}$.

Mas isso, sem esquecer que:

"tandis que la fonction d'édicter la réglementation protectrice concrète revient au droit matériel, la tâche du droit international privé est d'indiquer la loi applicable, mais en évitant que la différence du niveau de protection existant dans les systèmes juridiques avec lesquels une situation caractérisée par le besoin de protection d'un sujet a des liens puisse provoquer des solutions injustes pour le faible" ${ }^{\text {"169. }}$.

Bem por isso, o presente capítulo procura abordar as teorias que perpassaram o desenvolvimento do direito internacional privado tendo como pano de fundo, sempre, as relações entre genitores que deixam de conviver entre si, mas que desejam e devem manter a convivência individual com sua prole. $\mathrm{O}$ intuito maior é fornecer subsídios teóricos para

164 DOLINGER, Jacob. Da dignidade da diferença ao moderno direito internacional privado. Revista Forense, Rio de Janeiro, v. 100. n. 373. p. 113-120. maio/jun. 2004, p. 115.

${ }^{165}$ DOLINGER. Da dignidade..., cit., p. 120.

166 MAYER, Danièle. Évolution du statut de la famille en droit international privé. Journal du Droit International, Paris, n. 2, p. 447-469, abr-jun 1977, p. 456 e 461. Sobre os conceitos de justiça material e conflitual, veja-se, infra, o que vai no texto.

${ }^{167}$ BORRÁS RODRÍGUEZ. El "interes del menor"..., cit., p. 921, chama tal mecanismo de busca de "una 'localización' protectora para alcanzar una solución globalizadora que, en aras de la protección, abarque derecho material interno y derecho internacional privado".

${ }^{168}$ POCAR. La protection..., cit., p. 353.

${ }^{169}$ POCAR. La protection..., cit., p. 357. 
que, posteriormente, seja possível proceder à comparação de dois sistemas de determinação da lei aplicável à resolução da guarda e suas conseqüências a fim de se concluir a respeito da aptidão que cada qual demonstra possuir para a persecução dos valores acima relatados.

Assim, terminada essa abordagem teórica, proceder-se-á (na segunda parte da tese) à análise dogmática do sistema de direito internacional privado brasileiro e do sistema desenhado pela comunidade internacional, principalmente no âmbito da Conferência da Haia de Direito Internacional Privado, organização internacional essa que, no âmbito dos direitos da criança tem cumprido expressivo papel na tentativa de adensá-los relativamente às relações privadas internacionais ${ }^{170}$.

A análise de ambos os sistemas permitirá compará-los a fim de se justificar eventual ratificação da Convenção sobre competência, lei aplicável, reconhecimento, execução e cooperação em matéria de responsabilidade parental e medidas de proteção de crianças, firmada na Haia, em 1996. Mais do que avançar na busca de sistema coerente e coeso para a proteção das crianças em suas relações privadas no plano internacional - representada pelas convenções de 1980 sobre seqüestro, 1993, sobre adoção, 1996, sobre medidas de proteção (dentre as quais a guarda) e 2007, sobre alimentos ${ }^{171}$ - busca-se demonstrar a falência do sistema brasileiro de direito internacional privado da família - e das relações entre pais e filhos em particular - e sua discrepância relativamente às disposições de direito material a respeito, em nítida afronta ao princípio da harmonia material ou interna que "postula a uniformidade de valoração das mesmas situações dentro de cada ordem jurídica" 172 e "a coerência na regulação das situações da vida, o que obriga à eliminação de contradições normativas ou valorativas, designadamente através da adaptação" ${ }^{173}$. Tais discrepâncias, no mais das vezes, podem ocasionar a lesão de interesses legítimos dos envolvidos, produzindo resultados materiais injustos e mesmo inconstitucionais ${ }^{174}$.

\footnotetext{
${ }^{170}$ PARRA-ARANGUREN. La tarea complementaria..., cit., p. 51-67; DYER, Adair. A Conferência da Haia completa cem anos de trabalho no campo do direito dos menores. Trad. Teresa Trigo de Sousa. Infância e Juventude, Lisboa, n. 3, p. 9-33, 1993; DYER, Adair. Os direitos da infância no direito internacional privado. Trad. Teresa Trigo de Sousa. Infância e Juventude, Lisboa, n. 2, p. 9-37, 1992.

${ }^{171}$ DOLINGER. Da dignidade..., cit., p. 118 pergunta, após constatar que das mais de 30 convenções assinadas na Haia sobre direito internacional privado apenas duas foram aprovadas pelo país: "será mesmo que nenhuma outra das convenções da Haia deveria ser ratificada pelo Brasil?".

${ }^{172}$ PINHEIRO. Direito..., cit., v. 1, p. 239.

${ }^{173}$ PINHEIRO. Direito..., cit., v. 1, p. 240.

${ }^{174}$ GANNAGÉ, Léna. La hiérarchie des normes et les méthodes du droit international privé: étude de droit international privé de la famille. Paris: L.G.D.J., 2001, p. 42-43.
} 
Não se olvida que a incorporação do direito convencional - que aqui se vai defender gera dificuldades para sua aplicação. Dificuldades para se atingir a necessária interpretação uniforme entre os Estados parte a fim de atender os objetivos visados pela convenção, aliada ao constante desconhecimento dos agentes internos do Estado a respeito de seu teor e vigência e as dificuldades para a alteração das disposições convencionais quando se verifica seu "envelhecimento"175.

Ademais, como é cediço, a ratificação de convenções internacionais - mesmo daquelas que prevêem eficácia erga omnes, ou seja, que têm eficácia mesmo quando indicam a aplicação de uma lei estrangeira proveniente do sistema jurídico de um Estado que não é parte na convenção ${ }^{176}$ - não implica revogação da legislação interna. Nesse sentido a idéia de Erik Jayme:

"Dès lors que l'on évoque la communication en droit international privé, le phénomène le plus important est le fait que la solution des conflits de lois émerge comme résultat d'un dialogue entre les sources les plus hétérogènes. Les droits de l'homme, les constitutions, les conventions internationales, les systèmes nationaux: toutes ces sources ne s'excluent pas mutuellement; elles 'parlent' l'une à l'autre. Les juges sont tenus de coordonner ces sources en écoutant ce qu'elles disent”"177.

Bem por isso, entende-se necessária essa comparação pelos benefícios que, acredita-se, poderá a ratificação da convenção produzir relativamente ao sistema interno brasileiro.

\subsection{Normativismo, classicismo e segurança jurídica}

As relações de família com elementos estrangeiros representaram desde os primórdios do desenvolvimento do direito internacional privado campo fértil para o florescimento e a evolução da disciplina, permitindo, de um lado, a elaboração de um método fundado na escolha geral e abstrata da lei aplicável para a resolução dos conflitos de lei no espaço ${ }^{178}$, o

\footnotetext{
175 JAYME. Identité culturelle..., cit., p. 68.

${ }^{176}$ BORRÁS RODRÍGUEZ. El "interes del menor"..., cit., p. 932.

${ }^{177}$ POCAR. La protection..., cit., p. 357.

${ }^{178}$ Mas não foi só essa a reação das entidades políticas frente às relações privadas com elementos estranhos à jurisdição local, nos primórdios do desenvolvimento do direito internacional privado. Salientam HOLLEAUX, Dominique; FOYER, Jacques; GEOUFFRE DE LA PRADELLE, Géraud. Droit international privé. Paris: Masson, 1987, p. 162-164, três reações que deram origem a três diferentes métodos para lidar com o problema. A primeira reação alinhada pelos autores diz respeito à recusa absoluta em lidar com elementos de nacionalidade diversa da do foro, desencadeando sistema que acabava por negar
} 
chamado método conflitual ${ }^{179}$ e, de outro, a origem dos princípios do reenvio, do conflito de qualificação, da ordem pública, da fraude à lei e dos direitos adquiridos ${ }^{180}$, aptos a evitar a aplicação das leis indicadas pelo método clássico, como forma de se proceder a certa flexibilização do resultado alcançado pelas regras de conexão, fixas e técnicas ${ }^{181}$.

O método conflitual, desde Friedrich Carl von Savigny, vem procurando fixar as relações intersubjetivas em sua sede territorial, designando a lei vigente em tal território para reger tais relações ${ }^{182}$. É sabido que a teoria savigniana do direito, na esteira da filosofia kantiana, procurou estabelecer um novo dado teórico que explicaria juridicamente a persecução, pelas pessoas, de seus interesses sociais e econômicos por meio da autonomia privada e de uma concepção individualista ${ }^{183}$. Trata-se da relação jurídica, estrutura abstrata que procura explicar o fenômeno jurídico a partir de categorias préestabelecidas e considerada pelo autor atributos da pessoa ${ }^{184}$.

No âmbito do conflito espacial de normas, as diversas espécies de relações jurídicas deveriam permitir a determinação da lei aplicável com o recurso a princípios universalmente aceitos aos quais se poderia chegar explorando-se a verdadeira essência de tais relações. Rui Manuel Moura Ramos, ao narrar o pensamento savigniano, chama a atenção do leitor para a inspiração kantiana da teoria ao afirmar que os princípios universais decorrentes da busca da sede das relações jurídicas seriam verdadeiras emanações da razão pura e, nesse sentido, poderiam e deveriam ser aceitos por todos os Estados $^{185}$. Com isso, Savigny buscava voltar a garantir certa harmonia entre as decisões

juridicidade ao elemento estranho. A segunda foi representada pela aceitação, ainda que parcial, do elemento estrangeiro e implicou na construção de normas jurídicas materiais específicas para a questão, refletindo, então, o grau de aceitação da situação fática ou relacional (veja-se, por exemplo, o problema da adoção internacional, tratada pela Constituição brasileira como adoção por estrangeiros). A terceira, por fim, representada pela tentativa de banalização do que fosse estranho ao foro, procurou dotar de natureza nacional a norma de regulação estrangeira eventualmente aceita no foro, pregando que sua aplicabilidade só era possível dada a genérica autorização do sistema interno a sua aplicação.

${ }^{179}$ MAYER. Évolution..., cit., p. 447.

${ }^{180}$ DOLINGER. A evolução do direito..., cit., p. 336.

${ }^{181}$ DOLINGER. A evolução do direito..., cit., p. 340.

${ }^{182}$ FERRER CORREIA. Lições..., cit., p. 140, afirma: "a sede da relação jurídica determina o direito local a que está sujeita" O mesmo autor, adiante, chama a atenção para a realidade atual e lembra que hoje a escolha do elemento de conexão se faz "por classes ou grupos de questões de direito ou zonas de regulamentação normativa (...) e não por categorias de relações jurídicas” e chama a atenção para a freqüência com que o direito internacional privado distingue e recorta, "na mesma situação jurídica, diferentes aspectos ou perfis" (p. 141)

${ }^{183}$ AMARAL, Francisco. Direito Civil - Introdução. 3. ed. Rio de Janeiro/São Paulo: Renovar, 2000, p. 31.

${ }^{184}$ SAVIGNY, Friedrich Carl von. Sistema do Direito Romano atual, v. 8 [System des Heutigen Römischen Rechts]. Trad. Ciro Mioranza. Ijuí: Unijuí, 2004, p. 38.

${ }^{185}$ MOURA RAMOS, Rui Manuel Gens de. Direito internacional privado e Constituição: introdução a uma análise das suas relações. Coimbra: Coimbra, 1994, p. 16. 
tomadas nos diversos Estados europeus, não mais pela aplicação de um direito material uniforme - o direito romano recebido - mas, antes, pelo acordo que deveria se formar entre os vários Estados nacionais acerca da aplicação de seus princípios universais para a determinação da sede das relações jurídicas ${ }^{186}$. "Acordo esse que seria possível dado o carácter universal de tais critérios e princípios que derivariam forçosamente da natureza das coisas" ${ }^{\prime 187}$, formando verdadeira comunidade de direito. E nessa comunidade de direito, aplicar-se-ia o direito estrangeiro em atenção à verdadeira Weltanschauung estabelecida entre os Estados europeus. No entanto, essa suposta harmonização entre os diversos sistemas jurídicos no que respeita à determinação da sede das diversas relações jurídicas, em que pese ser coerente e teoricamente bem estruturada, dependia excepcionalmente das normas jurídicas de natureza interna. "Deixava pois de ser possível uma solução única e passava apenas a ser viável" ${ }^{\text {188 }}$, caso assim o entendessem os Estados.

A teoria savigniana sofreu, ademais, duro golpe com o avanço do positivismo e sua vocação para a "exaltação romântica da ciência" 189 na medida em que qualquer referência a valores perdia espaço na concepção jurídica. Assim, os princípios universais utilizados para a determinação da sede das relações jurídicas, ao se assentarem em valores superiores aos Estados e às ordens jurídicas concretas, deixaram de ser instrumento dos sistemas, que se reduziriam a um estrito legalismo, indiferente a quaisquer considerações valorativas ${ }^{190}$. Somou-se a isso uma gana codificadora que se alastrava pelos diversos países europeus e o resultado foi a obtenção de sistemas autônomos para a determinação da lei a aplicar na resolução dos conflitos de lei ${ }^{191}$. Daí a famosa dicotomia cunhada por Jitta que procurava separar um método universal e um método individual de direito internacional privado. Nos dizeres de Jacob Dolinger, caberia ao conjunto de Estados - membros, de resto, da sociedade internacional, desenvolvimento da comunidade jurídica do gênero humano, de Jitta, que é, por sua vez, sucessora da comunidade jurídica dos povos, de Savigny - “o

\footnotetext{
186 MARQUES DOS SANTOS, António. Direito internacional privado. In: MARQUES, Claudia Lima; ARAUJO, Nadia de. O novo direito internacional: estudos em homenagem a Erik Jayme. Rio de Janeiro: Renovar, p. 29-55, 2005, p. 40 salienta que "as normas de conflito bilaterais (ou multilaterais), como as do CC português, determinam o âmbito de aplicação da lei estrangeira nos mesmos termos que o da lei do foro, como manifestação do princípio internacionalista da igualdade entre lei do foro e lei estrangeira, que decorre directamente dos princípios formulados por Savigny, o qual visava, antes de tudo, a harmonia internacional de decisões, fosse qual fosse o sistema em que a questão jurídica fosse apreciada".

${ }^{187}$ MOURA RAMOS. Direito..., cit., p. 16.

${ }^{188}$ MOURA RAMOS. Direito..., cit., p. 18.

189 ABBAGNANO, apud MOURA RAMOS. Direito..., cit., p. 19.

${ }^{190}$ MOURA RAMOS. Direito..., cit., p. 19-20.

${ }^{191}$ MOURA RAMOS. Direito..., cit., p. 21.
} 
dever de assegurar, mediante regras positivas e mediante uma organização internacional da administração da justiça, o reinado do direito nas relações sociais que se formam entre os indivíduos" ${ }^{\prime 192}$. Não foi essa, no entanto, a postura que logo se adotou. Ao contrário, o positivismo radical levou à concepção de que cada ordenamento interno era regido pelas características essenciais da exclusividade e da universalidade, bastando-se. E ao se bastarem, poderiam abusar da designação da lex fori para a regência dos casos conectados com mais de um ordenamento jurídico, inclusive com recurso a normas jurídicas materiais desenhadas especialmente para reger os casos com elementos estrangeiros. Esse ensimesmar-se por que passaram os ordenamentos nacionais levaria o direito internacional privado, decerto, a uma situação bastante desconfortável, como se sua própria existência fosse posta em causa e como se, num jogo de xadrez, o xeque-mate estivesse prestes a se avizinhar.

E é assim que, na esteira de Rabel, passa-se a salientar, primeiramente na Alemanha, que o direito internacional privado persegue fins diversos do direito material interno, "é movido por outra lógica e assenta em quadros que se bem que em larga medida coincidentes com os das instituições internas possuem todavia um outro e mais amplo conteúdo"193. Surge a concepção do direito internacional privado enquanto sobredireito, direito de aplicação do direito (Rechtsanwendungsrecht) que busca "traçar a esfera de aplicabilidade das ordens jurídicas" e que, atuando "quase exclusivamente através de regras de conflitos", antes de escolher a melhor lei, deve indicar a lei melhor colocada para intervir na questão ${ }^{194}$. Com isso, passa a ser visto como um ramo do jurídico cujas normas possuiriam "natureza superior às regras materiais" a utilizar um elemento de conexão pré-determinado ou determinável segundo critérios descritos na própria norma. São, por isso, chamadas de hard-and-fast Rules $^{196}$.

Se tal concepção foi responsável pela fuga que se empreendeu do rigor metodológico construído pelo positivismo nacionalista, foi também responsável por uma cisão no conceito de justiça. Com efeito, ao delinear funções diversas para o sobredireito e o direito

\footnotetext{
192 DOLINGER. Direito..., cit., p. 148.

${ }^{193}$ MOURA RAMOS. Direito..., cit., p. 26.

194 FERRER CORREIA, António. Principais interesses a considerar na resolução dos conflitos de leis. Direito internacional privado - Estudos Jurídicos III. Coimbra: Atlântida, p. 84-92, 1970, p. 84.

${ }^{195}$ MOURA RAMOS. Direito..., cit., p. 27-28.

${ }^{196}$ FERRER CORREIA. Lições..., cit., p. 142. Segundo BORRÁS RODRÍGUEZ. El "interes del menor"..., cit., p. 940-941 as normas rígidas com critério de conexão único não permitem, em termos de direito das crianças, valorar onde realmente se encontra o interesse da criança.
} 
material, tal doutrina logo tratou de sublinhar que também as idéias de justiça do direito internacional privado e do direito material deveriam ser diferentes. As regras de conexão, ao estatuírem um tipo específico de justiça, livravam-se, por ora, da crítica que contra elas tinha sido levantada no sentido de serem regras às quais faltava sensibilidade para imperativos éticos ${ }^{197}$.

No entanto, o apego ao método savigniano de determinação abstrata da lei a aplicar obtido pela conjugação da situação juridicamente relevante a um elemento localizador da relação no espaço, tornava bastante limitada, inclusive, a realização da justiça conflitual ${ }^{198}$. Com efeito, valendo-se de um juízo a priori, o método clássico ou normativo parte da norma jurídica para os fatos, passando pelo elemento de conexão, como salienta Amilcar de Castro ${ }^{199}$. Nesse sentido, sua justiça é realizada quando se consegue determinar a correta localização geográfica dos fatos, fazendo com que seja aplicada a lei material daquele Estado que aparenta apresentar vínculos mais estreitos com a quaestio iuris decidenda sem que, entretanto, se pudesse indagar acerca da aptidão que aquela lei teria para produzir um resultado materialmente justo. Restaria ao ordenamento do foro, apenas, a possibilidade de afastar a aplicação da lei estrangeira nas hipóteses em que se configurassem os princípios da ordem pública, da fraude à lei, da instituição desconhecida etc. garantindo a aplicabilidade de uma lei que pudesse causar menores prejuízos ao sistema, mas de novo sem se preocupar com os interesses dos envolvidos na relação fática. Tais princípios, como adverte Moura Ramos, inserem a incerteza no método do direito internacional privado, na medida em que visam proceder à correção na indicação da lei ${ }^{200}$.

Assume-se, então, o direito internacional privado como um ramo do saber jurídico que há de definir as formas de coabitação das ordens jurídicas nacionais, apresentando-se como um direito "tecnocratizado", despreocupado com o dever-ser, "dispensado de prestar atenção a quaisquer consideranduns valorativos e apenas preocupado em maximizar a perfeição dos seus mecanismos de atuação"201 na tentativa de efetivar certo grau de segurança jurídica. António Ferrer Correia, a propósito, fala em "sistema puramente

\footnotetext{
${ }^{197}$ MOURA RAMOS. Direito..., cit., p. 29.

198 Para uma crítica à distinção entre justiça material e justiça conflitual, veja-se MOURA RAMOS, Rui Manuel Gens de. Droit international privé vers la fin du vingtieme siecle: avancement ou recul? Documentação e Direito Comparado: Boletim do Ministério da Justiça, Lisboa, n. 73/74, p. 85-125, 1998, p. 94, quando afirma que antes que uma espécie distinta de justiça, dita justiça conflitual não é nada mais que justiça tout court (geralmente chamada material) relativa às situações com conexão múltipla.

${ }^{199}$ CASTRO. Direito..., cit., p. 187.

${ }^{200}$ MOURA RAMOS. Direito..., cit., p. 88.

${ }^{201}$ MOURA RAMOS. Direito..., cit., p. 98.
} 
formal, cego para os autênticos valores do direito"202 que:

"na ortodoxia dos seus dogmas, na sua 'justiça' estritamente formal, no positivismo e particularismo nacional da sua concepção basilar tal como o final do século [XIX] no-la transmitiu, na ruptura com a inspiração universalista de um Savigny e de um Mancini, o DIP não estava em condições de bem realizar a tarefa que lhe era assinada pela própria natureza das coisas" ${ }^{, 203}$.

Esse, no entanto, o direito internacional privado que se professa - em geral e ainda - no Brasil.

\subsection{Flexibilidade e tentativa de realização de justiça por meio da aplicação das normas} de direito internacional privado

Atenta à distinta concepção de justiça que pode existir na comparação dos escopos do direito material e do direito internacional privado $^{204}$, a doutrina - tanto internacional, como parte da doutrina nacional - buscou proceder a ajustes e correções no comportamento desta disciplina, enquanto ramo de uma ciência social, no campo da realização do direito. É justamente nesse sentido que se levanta a crítica de Moura Ramos à impermeabilização que no direito internacional privado se realizou em face dos valores assentes na sociedade:

"enquanto ramo de uma ciência social, não se entendia a sua alergia aos valores e preocupações que constituem o núcleo distintivo daquelas, a sua indiferença, não já quanto aos resultados concretos da aplicação dos seus comandos, como agora quanto à prossecussão de certos fins sociais que a ordem jurídica no seu todo tem em vista e cuja realização promove através dos seus vários sectores. Não se compreendia a sua sistemática não participação nas tarefas de modelação da sociedade que o direito enquanto tal não está dispensado de visar. Não se aceitava a

202 FERRER CORREIA, António. O método conflitual em direito internacional privado e as soluções alternativas. Revista de Direito Comparado Luso-Brasileiro, Rio de Janeiro, n. 1, p. 1-24, jul. 1982, p. 3.

${ }^{203}$ FERRER CORREIA. O método..., cit., p. 21. Mormente no direito de família essa falta de condições se faz sentir na medida em que o distanciamento da realidade é mais rápida e profundamente sentido, pois os fatos antecedem as regras normativas como ressalta TANAKA, Áurea Christine. O divórcio dos brasileiros no Japão: o direito internacional privado e os princípios constitucionais. São Paulo: Kaleidos Primus, 2005 , p. 29.

204 BAPTISTA MACHADO, João. Lições de direito internacional privado. 3. ed. (reimp.). Coimbra: Almedina, 2006, p. 43 chama a atenção para o fato de as regras de direito internacional privado, quando aplicadas, não darem azo à constituição, modificação ou extinção de direitos, donde deriva a diferença entre justiça material, que provoca tais conseqüências, e justiça conflitual, que não as provoca. Em sentido contrário, MOURA RAMOS. Droit international..., cit., p. 94. 
sua insensibilidade à promoção e actuação dos valores jurídicos fundamentais" ${ }^{205}$.

E é justamente na altura em que estas críticas mais veementes são dirigidas ao direito internacional privado de feição abstrata e localizadora que se propõe, de um lado, a sua permeabilidade aos valores sociais e públicos e, de outro, a elaboração de princípios que pudessem garantir à disciplina mecanismos mais eficazes de realização de justiça, ainda que continuasse ocupada em efetivar uma justiça eminentemente conflitual.

Assiste-se a um

"paulatino abandono das regras de conexão fixas, inflexíveis, que determinam a lei aplicável, para se adotar o princípio amplo e flexível da lei mais próxima, mais intimamente vinculada com as partes ou com a questão jurídica, que faculta aos tribunais maior poder discricionário na escolha da lei aplicável. Este novo approach se baseia na idéia de intensidade maior de ligação, e é conhecido como o princípio da proximidade" 206.

O princípio da proximidade encontra campo fértil de aplicação - sem que se impeça sua aplicação também a outras situações - nas hipóteses em que a relação fática com elemento estrangeiro apresenta como um dos sujeitos envolvidos, pessoa em condição de hipossuficiência, como é o caso das crianças ${ }^{207}$, seres em estágio formativo, dependentes que são da convivência, do carinho e do desvelo não só de seu pai e de sua mãe, como também dos membros da família alargada, como é o caso dos avós, irmãos mais velhos, tios e primos, por exemplo. Talvez por isso a Convenção da Haia concernente à competência, lei aplicável, reconhecimento, execução e cooperação em matéria de responsabilidade parental e medidas de proteção da criança, de $1996^{208}$ tenha sido a primeira convenção de direito de família firmada na Haia a prever a possibilidade de aplicação da lei do país que apresentar substancial conexão com a situação fática a decidir" ${ }^{209}$. Jacob Dolinger, dando ênfase a tal norma, afirma que "aqui já nem se exige maior proximidade, maior conexão, bastando haver substancial conexão, numa considerável expansão da liberdade de ação do julgador ou autoridade encarregada de

\footnotetext{
${ }^{205}$ MOURA RAMOS. Direito..., cit., p. 99.

${ }^{206}$ DOLINGER. Direito..., cit., p. 150-151.

${ }^{207}$ DOLINGER. Contratos..., cit., p. 545 menciona os consumidores, os empregados e as vítimas de atos ilícitos.

${ }^{208}$ Veja-se, a respeito, o capitulo IV, item 1, infra.

${ }^{209}$ PINHEIRO. Direito..., cit., v. 1, p. 252 aplaude o sistema de conexão alternativa em matéria de proteção da criança.
} 
proteger a criança" 210 .

Isso porque as regras flexíveis de direito internacional privado, as chamadas openended Rules $^{211}$ de inspiração norte americana ${ }^{212}$, apresentam a possibilidade de se proceder à escolha da lei aplicável dentre os diversos ordenamentos potencialmente aptos a regular o aspecto da vida que demanda intervenção, segundo critérios determinados pela legislação, pela doutrina ou pela jurisprudência ${ }^{213}$. Essa possibilidade de escolha da lei mais próxima, ou da melhor lei (better law approach) que se abre ao intérprete não foi recebida imune de críticas. Ao contrário, autores acostumados com o sistema rígido de escolha da lei aplicável pelo sistema da verificação de sua sede jurídica acusaram a doutrina recém-criada de constituir-se em verdadeiro sistema de escolha de resultados ${ }^{214}$. Como resposta, o formulador dos princípios de preferência, o norte-americano David Cavers, aduziu que as modificações por ele sugeridas no método do direito internacional privado tinham natureza meramente indicativa, não obrigando o julgador a segui-las e que ele próprio entendia que só teriam aplicabilidade nas hipóteses em que o método tradicional, por alguma razão, falhasse $^{215}$. Em que pese a argumentação desenvolvida pelo criador dos principles of preference, deve-se aduzir que há, em doutrina, quem enxergue na formulação de tais princípios não a estruturação de indicações ou recomendações aos magistrados, mas, antes, a formulação de verdadeiras normas de conexão substancial ${ }^{216}$.

A tendência de se dotar as regras de conflito de certa abertura se constrói a partir da adoção de uma orientação funcional, de resto já verificada em outros ramos do direito, e

${ }^{210}$ DOLINGER. A evolução do..., cit., p. 343.

${ }^{211}$ FERRER CORREIA. Lições..., cit., p. 142.

${ }^{212}$ Sobre o primeiro e o segundo Restatement of the Law, Conflict of Laws, seus condicionamentos históricos, e as críticas que sofreram, veja-se, por último, a interessante pesquisa de TANAKA. $O$ divórcio..., cit., p. 23-47. Saliente-se, entretanto, que a idéia de conexão flexível só vai aparecer no Restatement $2^{\text {nd }}$. O Restatement $1^{\text {st }}$ seguiu a concepção clássica do direito internacional privado, com nítida preferência pela lex fori como elemento de conexão.

${ }^{213}$ Está-se a referir às hipóteses de determinação da lei aplicável, após submissão da situação fática ao método do direito internacional privado, seja ele qual for. Diferente é a hipótese de efetiva escolha da lei de regência pelas partes, ainda que com base em critérios estabelecidos pelo sistema ao elencar critérios de conexão possíveis, limitando, portanto, a possibilidade de escolha. Isso por se tratar de situação em que há margem para a aplicação do princípio da autonomia de vontade das partes que escolherão a lei que regerá a situação fática, depois de sua verificação fenomênica. Assim, por exemplo, MARQUES, Cláudia Lima. Novos rumos do direito internacional privado quanto às obrigações resultantes de atos ilícitos (em especial de acidentes de trânsito). Revista dos Tribunais, São Paulo, v. 77, n. 629, p. 72-92, 1988, p. 82, ao relatar os critérios estabelecidos pela lei suíça para que causador e vítima de danos possam escolher, a posteriori, a lei que regulará a atribuição de responsabilidade, vinculando o órgão decisor.

${ }^{214}$ Assim, EVRIGENIS, Dimitrios J. Tendances doctrinales actuelles en droit international privé. Recueil des Cours, Leyde: A. W. Sijthoff, v. 118, p. 313-434, 1966, p. 338. No mesmo sentido, TANAKA. $O$ divórcio..., cit., p. 45.

${ }^{215}$ TANAKA. $O$ divórcio..., cit., p. 32.

${ }^{216}$ FERRER CORREIA. Lições..., cit., p. 155, nota 180. 
que visava proceder a certo equilíbrio entre a certeza e a segurança jurídica, já presentes no sistema, de um lado, e a flexibilidade que este almejava na seara jusprivatista internacional, de outro ${ }^{217}$. A fim de coordenar tais valores, defende-se, em doutrina e com reflexos nas fontes da disciplina - sejam elas internas, sejam elas de origem internacional (normas convencionais) -, a não aplicação das regras rígidas de direito internacional privado, capazes de gerar previsibilidade e segurança jurídica, sempre que de tal aplicação decorrer a possibilidade de se colocar em risco a realização de valores considerados fundamentais para a unidade do sistema, sublinhando-se a conveniência de que o sistema de direito internacional privado seja dotado de uma cláusula geral de exceção ${ }^{218}$.

Assim, seja pela construção da norma jurídica com a indicação de critérios alternativos ou subsidiários de conexão, seja autorizando-se o recurso às cláusulas de exceção ${ }^{219}$, fato é que o sistema de direito internacional privado procurou abrir a possibilidade de que o julgador se afastasse do método clássico, sempre com o intuito de proceder à justiça conflitual, permitindo a aplicação de uma lei que, em princípio não seria a aplicada, muito embora fosse, na hipótese, aquela que maior conexão apresentasse para a resolução da situação fática. Abre-se o sistema em prol da conexão mais estreita e isso acarreta, também, uma menor incidência dos clássicos princípios do direito internacional privado, cuja função precípua fora, sempre, a de proceder a reparos na lei a aplicar. Isso porque "a correção de resultados indesejáveis, tradicionalmente (...) operada [pelos princípios da ordem pública, da fraude à lei, da instituição desconhecida, da adaptação etc.], se fará no processo da aplicação da própria regra de conexão, dispensando os recursos aos princípios corretivos" 220 .

No entanto, o desenvolvimento das idéias que procuraram emprestar ao direito internacional privado maior proximidade com o caso concreto, não pararam por aqui. Insta verificar esquemas teóricos outros que procuram abrir ainda mais o conflito de leis a fatores que até então eram mantidos a longa distância da disciplina.

Volta e meia surge na doutrina uma construção do método do direito internacional privado preocupada em explicar - muitas vezes sem um alcance rigorosamente limitado,

${ }^{217}$ MOURA RAMOS, Rui Manuel Gens de. Les clauses d'exception en matiere de conflits de lois et de conflits de juridictions. Documentação e Direito Comparado: Boletim do Ministério da Justiça, Lisboa, n. 57/58, p. 293-322, 1994, p. 305.

${ }^{218}$ MOURA RAMOS. Droit international..., cit., p. 99.

219 MOURA RAMOS. Rui Manuel Gens de. Da lei aplicável ao contrato de trabalho internacional. Coimbra: Almedina, 1990. p. 568.

${ }^{220}$ DOLINGER. A evolução do..., cit., p. 345. 
como sublinha Ferrer Correia ${ }^{221}$ - a necessidade de o sistema de solução de conflitos de leis no espaço se abrir a princípios e critérios da justiça material. Como salienta citado autor, a idéia em si não é negativa ou positiva, mas deve ser, certamente, reservada para situações excepcionais, como queria Kegel. A dificuldade, entretanto, está sempre no estabelecimento dos critérios para a distinção, com clareza, de tais hipóteses ${ }^{222}$. E nesse sentido, várias foram as construções teóricas que se desenvolveram e que continuam a ser formuladas para explicar porque, coexistindo muitos ordenamentos jurídicos (1), por vezes alguns se mostram muito relacionados à situação fática ao passo que em outras hipóteses, não parece haver correlação relevante com os fatos (2), ocasionando a necessidade de uma multiplicidade de métodos (3) que passa pela abertura a valores socialmente relevantes e pelo recurso a técnicas mais adequadas para a construção da norma de direito internacional privado $(4)^{223}$.

Assim, por exemplo, Hijmans é comumente apontado pela doutrina como um dos formuladores de um posicionamento substancialista do direito internacional privado. Argumenta tal autor que havendo várias conexões, todas elas de valor ou peso sensivelmente identificáveis, dificultando a escolha da better law, seria de todo recomendável que se buscasse a resolução do litígio na própria relação da vida que se está a considerar. Explica que a realidade internacional contém em si mesma a sua própria regulamentação jurídica. Assim, é de se acompanhar o pensamento de Ferrer Correia a respeito de tais idéias ${ }^{224}$. Com efeito, o autor português crítica a teoria de Hijmans, aproximando-a à teoria do direito livre, pela amplitude de liberdade que se estaria a outorgar ao julgador na hipótese deste considerar que os critérios possíveis de conexão teriam, todos eles, valor e importância aproximados, abrindo-se o caminho para uma decisão que não se sabe absolutamente qual será, dado o grau de discricionariedade que o autor holandês entregaria ao juiz. Isso porque nem sequer se cogita da formulação, pelos órgãos competentes, de regras materiais para aplicação aos casos com elementos estrangeiros, mas, antes, entrega-se ao julgador espécie de carta assinada em branco para ser preenchida pela decisão formulada - e fundamentada - livremente. Mesmo que se exija a necessária fundamentação, perdem-se critérios de controle de seu conteúdo.

\footnotetext{
${ }^{221}$ FERRER CORREIA. Lições..., cit., p. 147.

${ }^{222}$ FERRER CORREIA. Lições..., cit., p. 149-150.

223 ESPINAR VICENTE, Jose Maria. Ensayos sobre teoría general del derecho internacional privado. Madrid: Civitas, 1997, p. 98-102, destrincha os quatro tópicos mencionados no texto na tentativa de reconstruir a idéia básica à disciplina do conflito de leis no espaço em perspectiva que chama de ortodoxa.

${ }^{224}$ FERRER CORREIA. Lições..., cit., p. 148.
} 
Outra idéia referenciada pela doutrina como mecanismo de permeabilidade do direito internacional privado aos valores e a certa regulamentação material é aquela defendida por Arthur von Mehren para quem o sistema de solução de casos multi-conectados deveria levar em consideração os "pontos de vista de todas as ordens jurídicas que tenham um interesse legítimo em controlar o caso sub judice ${ }^{225}$, buscando-se transformar o litígio por aquilo que entre eles houver de comum, ou de intermediário. Amplia-se o papel do direito comparado na formulação da decisão, mas corre-se o risco da distorção dos sistemas em causa, possibilitando-se que a decisão afinal obtida torne-se algo que, tamanha a artificialidade de sua construção, dificilmente encontrará respaldo e execução em ordenamentos estrangeiros melhor colocados para concretizar os efeitos que a decisão visava realizar, tornando-a inexeqüível, por não obtenção do necessário exequatur.

Para o escopo que este trabalho visa alcançar, no entanto, referenciar todas as tentativas de dotar o direito internacional privado de certa preocupação substancial seria esforço exagerado e despido de sentido. Partindo-se da premissa de que as relações familiares - e dentre elas as relações entre pais e filhos, em particular - assumem grande importância na conformação da sociedade e de seus interesses, não parece exagero afirmar ser esta mesma sociedade a principal interessada na regulação que se venha emprestar a tais relações. Assim, se alguma tendência substancialista tiver de ser reconhecida para que tal desiderato possa ser atingido sempre que tais relações apresentarem um elemento qualquer de estraneidade, crê-se que os valores postos em relevo para tanto devam ser os princípios constitucionais que dotam a família de dignidade e sobrelevam a multiplicidade de formas por que pode se apresentar na sociedade, os direitos humanos fundamentais, mormente aqueles reconhecidos ou positivados pela comunidade internacional e certa tendência verificável, mormente em algumas recentes convenções assinadas no âmbito da Conferência da Haia de Direito Internacional Privado, no sentido de dotar o sistema de direito internacional privado convencional de normas materiais uniformes. Para tanto, vaise aqui aprofundar um pouco a análise do posicionamento teórico defendido por Rui Manuel Moura Ramos, Erik Jayme e François Rigaux.

Essa análise, no entanto, como afirmado já na introdução da tese, não pretende avançar além da descrição de aspectos da produção científica de tais autores considerados relevantes para o desenvolvimento dos capítulos seguintes, seja para com eles concordar

${ }^{225}$ FERRER CORREIA. Lições..., cit., p. 148. 
ou deles discordar. Decerto deve ser sublinhado que tais posicionamentos, longe de negar o método conflitual ${ }^{226}$, procuram complementá-lo ou aperfeiçoá-lo, assim como ocorre com o princípio da proximidade - cujo grande defensor entre nós, como se viu acima, tem sido o Professor Jacob Dolinger - ou com o estabelecimento de critérios alternativos ou subsidiários de conexão. Isso porque, como salienta Ferrer Correia,

"O DIP atual assume, pois, como característica predominante, a de procurar atingir os seus objetivos utilizando diferentes meios ou vias metodológicas. O seu método é pluralista, multidimensional. Certo que, no fundamental, a posição definida pela doutrina clássica se mantém inalterada. O DIP é essencialmente direito de conflitos. As soluções dos problemas decorrentes das soluções plurilocalizadas colhem-se, na generalidade dos casos, nos preceitos jurídico-materiais da lei com a qual a situação concreta se achar mais estreitamente conexa. Por outro lado, essa mais estreita conexão espacial deverá ser indicada por uma norma, ou seja, uma norma de conteúdo rígido ou uma daquelas regras que consagram todo um leque de opções possíveis (...). Tal norma deverá ser estabelecida em função dos fins gerais do DIP, dos quais sobressai a harmonia jurídica internacional ou uniformidade de decisões"227.

Tomando-se em consideração essas idéias aqui reproduzidas, e atentando-se para o fato de ser o sistema de direito internacional brasileiro vigente quase rudimentar, mormente em face dos avanços sociais experimentados pela sociedade brasileira nos dois últimos decênios, buscar-se-á na doutrina dos autores citados elementos que possam iluminar senão a construção da norma vigente no direito internacional privado brasileiro, nem a daquela norma sugerida pela sociedade internacional acerca do tema objeto de estudo, iluminar, ao menos, a comparação dos dois sistemas, a fim de se perquirir qual, dentre eles, é o que se mostra mais de acordo com os valores que regem a sociedade brasileira, suas famílias e as relações internacionais do país.

\footnotetext{
${ }^{226}$ Talvez a grande negação que se empreendeu ao método do direito internacional privado seja devida a Brainerd Currie. Com efeito, a teoria da governmental interest analysis, ao pregar a aferição do grau de interesse político dos Estados cujos ordenamentos encontram-se em conflito espacial no sentido de ver sua regra material efetivamente aplicada ao caso concreto, fundamenta-se na concepção de que o conflito de leis é uma conseqüência da interferência recíproca da esfera de aplicação das várias leis nacionais. É, portanto, um problema político. Nesse sentido, sustenta a necessidade de se aplicar a lei do Estado que efetivamente possui tal interesse. E na hipótese de se deparar com dois ou mais ordenamentos politicamente interessados, Currie defende a aplicabilidade da lex fori. A mesma solução é defendida quando a análise empreendida concluir pela ausência de interesses políticos em todos os ordenamentos envolvidos. As idéias do autor são analisadas, com riqueza por MOURA RAMOS. Direito..., cit., p. 132-140.

${ }^{227}$ FERRER CORREIA. Lições..., cit., p. 167.
} 
Ciente da necessidade de se defender certa permeabilidade do direito internacional privado aos valores que conformam a sociedade a que se dirige e certo de que tais valores vêem plasmados, principalmente, nas constituições dos diversos países, Rui Manuel Moura $\operatorname{Ramos}^{228}$ defende a necessária adequação das regras de conflito aos ditames constitucionais, chegando mesmo a defender sua submissão ao controle de constitucionalidade das leis ${ }^{229}$, assim como o controle de constitucionalidade das leis estrangeiras por aquela norma mandadas aplicar ${ }^{230}$. Sua construção teórica, longe de tentar afastar do método do direito internacional privado sua raiz conflitual, procura, antes, adequá-lo aos valores sociais, negando-lhe qualquer pretensão asséptica. E isso porque reconhece que o direito internacional privado, assim como os demais ramos do direito, "ainda que por formas e com intensidade diversas, participa igualmente de uma tarefa de modelação da sociedade a que se dirige"231. Assim, por exemplo, se uma constituição estabelecer que incumbe à família, à sociedade e ao Estado o dever de assegurar à criança e ao adolescente, com absoluta prioridade, uma série de direitos, dentre os quais o direito de convivência familiar, colocando-os à salvo de uma série de atitudes que considera perniciosa $^{232}$, caberá ao Estado garantir que as normas de direito internacional privado sejam observadas com tal moldura axiológica. Assim, pouco importando se será o Estadolegislador, o Estado-juiz, ou, ainda, o Estado-administração, fato é que alguém haverá de se desincumbir da tarefa de reconstruir a norma, estudando-a à luz da interpretação constitucional recente, editando, eventualmente, "normas de integração ou definidoras de situações fáticas até então não abrangidas por determinação legal" ${ }^{\text {233 }}$. Assim, por exemplo, uma norma que vise regular o conflito de leis no espaço e que determine, para o cumprimento de tal desiderato, a obrigatoriedade de que a criança incapaz ostente o mesmo domicílio do chefe de sua família precisará de interpretação adequada, que reconstrua seu sentido, mormente se tal instituto, não se coadunando mais aos valores sociais, tiver dado

\footnotetext{
${ }^{228}$ O autor citado é o Catedrático de direito internacional privado da Universidade de Coimbra e atual presidente do Tribunal Constitucional de seu país. As relevantes funções públicas que desempenha atualmente demonstram, talvez, como sua teoria pode ser pragmaticamente reconhecida em Portugal.

${ }^{229}$ PINHEIRO. Direito..., cit., v. 1, p. 251-252 refere que o problema se pôs em decorrência do princípio da igualdade, constitucionalmente desenhado, ao qual se contrapunham algumas normas de direito internacional privado que determinavam, por exemplo, a aplicação da lei pessoal do marido aos casos relativos a regime de bens e divórcio.

${ }^{230}$ MOURA RAMOS. Direito..., cit., p. 34-35.

${ }^{231}$ MOURA RAMOS. Direito..., cit., p. 103.

${ }^{232}$ Como o faz a norma do art. 227, caput, da Constituição da República Federativa do Brasil, por exemplo.

${ }^{233}$ MARQUES; CACHAPUZ; VITORIA. Igualdade..., cit., p. 23. Continuam as autoras, salientando tratar-se de "perspectiva de estudo que garante a brecha necessária à recepção de novas doutrinas que possam conformar situações do mundo dos fatos ao sistema jurídico posto".
} 
lugar à plena igualdade entre homem e mulher (marido e mulher, companheiro e companheira) na condução dos desígnios familiares. É que se assim se comportar o ordenamento e se, por exemplo, um pai decidir deixar o território do Estado em que era domiciliado em companhia de seus filhos, sem o consentimento da mãe destes, e se numa visão exclusivamente conflitualista se considerar que as crianças ostentam agora novo domicílio, poderá a decisão vir a ser tomada segundo a lei do Estado em que agora se encontram (lei do domicílio do chefe da família e das crianças), lei esta que pode privilegiar os interesses do pai sem que isso constitua, a priori, hipótese de ofensa à ordem pública, mormente se o pai agiu com nítida intenção de forum shopping, escolhendo Estado que lhe privilegiava segundo critérios aceitos pela ordem valorativa do foro de origem, fazendo-o, no entanto, não com a intenção de fraudar a lei, mas dando vazão ao modelo do conflito móvel ${ }^{234}$. Nesse caso, as crianças subtraídas de seu habitat restariam desprotegidas e possivelmente afastadas de forma intensa - senão definitiva - do convívio com a mãe. Por outro lado, um ordenamento cujas regras de direito internacional privado tivessem sido construídas - ou interpretadas, o que de resto constitui-se em construção da norma a aplicar - com observância dos valores expressos no texto constitucional poderia certamente dar azo a resultado diverso, aplicando o juiz a lei mais próxima ao caso a decidir.

De tudo quanto ficou exposto, parece, afinal, que a construção de Moura Ramos mais do que elaborar um mecanismo de flexibilização do direito internacional privado tem a especial virtude de constituir-se em pano de fundo teórico para a abertura desse sistema aos valores sociais ${ }^{235}$ por meio da pesquisa da lei mais próxima à situação a considerar. E tal virtude reflete justamente, no âmbito deste trabalho, a mola propulsora de uma necessária adequação das normas brasileiras de direito internacional privado à crescente complexidade das relações familiares e de sua multiplicidade imanente, especialmente porque encontram assento constitucional.

Partindo das considerações de Moura Ramos, pode-se chegar à construção que faz Erik

234 CALVO CARAVACA, Alfonso-Luís; CARRASCOSA GONZÁLEZ, Javier. Derecho Internacional Privado. v. 1. 5. ed. Granada: Comares, 2004, p. 252, chamam a atenção para a distinção entre conflito móvel e fraude à lei: "conflicto móvil y fraude de lei son instituciones diferentes. En el conflicto móvil, el cambio de circunstancia empleada como punto de conexión por la norma de conflicto no se produce maliciosamente, esto es, con el objetivo exclusivo de provocar un cambio de ley aplicable" (destaques do original compulsado).

${ }^{235}$ Lembre-se que o texto elaborado pelo autor constituiu sua dissertação de mestrado na Universidade de Coimbra, apresentada em outubro de 1977, época em que as idéias a respeito da busca da better law ou do princípio da proximidade eram ainda incipientes. 
Jayme acerca dos conflitos de civilização ${ }^{236}$ ou de culturas ${ }^{237}$, entendendo-se por cultura:

"o conjunto de formas típicas de viver de grandes grupos de pessoas, incluindo suas atividades, suas formas básicas de pensamento, de expressão e de valores, sua maneira de ver o mundo. Em sentido lato, cultura é o resultado da atuação do homem no mundo, aquilo que é diferente da natureza: o mundo cultural é o mundo realizado pelo homem, inclusive suas normas postas e seguidas no dia-a-dia de uma sociedade" ${ }^{, 238}$.

Assim, na medida em que os princípios constitucionais "cristalizam"239 disposições relativas aos direitos humanos e que as constituições tornam-se pródigas no reconhecimento de direitos fundamentais, acabam por refletir, com efeito, certo patrimônio comum de valores jurídicos universais que merecem consideração ${ }^{240}$, muito embora não haja identidade de extensão entre os diversos direitos individuais nos diversos sistemas jurídicos a considerar. A construção do autor, no entanto, levando em consideração aspectos de ordem cultural - ao lado ou ao largo, conforme a hipótese, dos critérios tradicionalmente aceitos pelo direito internacional privado, como a nacionalidade, o domicílio ou a residência habitual - visa justamente adequar a aplicação de uma ou de outra lei à maior proximidade (cultural) existente entre o caso e o sistema de que provém a lei a considerar. Assim é que, por exemplo, o autor aplaude decisão da Corte suprema da Baviera que decidiu - em questão prévia - aplicar a lei austríaca em detrimento da lei polonesa, em caso de regulação do exercício da autoridade parental de uma criança que ostentava dupla nacionalidade (austríaca e polonesa) por duas razões: primeiramente porque a mãe da criança, portadora também ela da dupla nacionalidade, considerava-se mais austríaca que polonesa e depois porque ao tempo da decisão (1984), a cultura austríaca apresentava infinitamente maiores semelhanças com a cultura alemã vigente na Baviera que a cultura polonesa ${ }^{241}$. De um lado, poder-se-ia dizer, leva-se em consideração a identidade cultural subjetiva da responsável pela criança; de outro, dá-se valor à

\footnotetext{
236 Expressão preferida pelos autores franceses, como salienta MARQUES, Cláudia Lima. O direito internacional privado solucionando conflitos de cultura: os divórcios no Japão e seu reconhecimento no Brasil. Revista de Informação Legislativa, Brasília, v. 41, n. 162, p. 91-113, 2004, p. 93. Veja-se, a respeito, DÉPREZ. Droit international..., cit.

237 Como asseveram MARQUES; CACHAPUZ; VITORIA. Igualdade..., cit., p. 12, cultura essa que, encontrando no direito forma de expressão, ao mudar em decorrência de avanços valorativos, econômicos, históricos, éticos e religiosos de seu tempo, acarreta mudanças mais ou menos sensíveis em variados ramos do saber jurídico e não só no direito internacional privado.

${ }^{238}$ MARQUES. O direito..., cit., p. 92.

${ }^{239}$ A expressão é de TANAKA. $O$ divórcio..., cit., p. 63.

${ }^{240}$ JAYME. Identité culturelle..., cit., p. 49.

${ }^{241}$ JAYME. Identité culturelle..., cit., p. 178-179.
} 
identidade cultural coletiva vigente no Estado da residência habitual das interessadas (cultura que as circunda). Pode ocorrer, no entanto, conflito entre tais fatores de natureza cultural. Indaga-se, por exemplo, como se deveria proceder, à luz desse modo de pensar, em face de uma criança de origem japonesa ou árabe-muçulmana que, criada no Brasil, esteve, no entanto, imersa em valores culturais estranhos ao ambiente, porquanto criada em espécie de gueto onde prevaleciam os valores culturais alienígenas. Havendo discrepância entre aquilo que se chamou aqui de identidade cultural subjetiva e identidade cultural coletiva (de toda a coletividade), qual delas privilegiar? Tal consideração é importante, mormente se se atentar para a possibilidade de que a lei aplicável, pelos critérios tradicionais do direito internacional privado, ser a lei do domicílio ou a lei do foro (que no caso coincidem). Quid iuris se houver comportamento absolutamente refratário à lei do foro ou à lei do domicílio por parte dos envolvidos? Deve ceder a determinação da lei interna de direito internacional privado que mandava aplicar a lei material local e aplicar, por acaso, a lei estrangeira ${ }^{242}$ ? Não estaria, tal mecanismo, funcionando como espécie de princípio da ordem pública às avessas? ${ }^{243}$ Jayme entende ser esta a expressão perfeita de um direito internacional pós-moderno, que utiliza uma combinação de diferentes formas de aproximação e renuncia a toda forma de puro dogmatismo ${ }^{244}$.

Assim, deve-se perquirir em que medida as convenções internacionais que serão analisadas no capítulo IV da tese, ao lado da Convenção sobre os direitos da criança, de 1989, podem servir de normas narrativas para a resolução de conflitos de valores e garantir certa coerência da ordem jurídica interna ao descrever os objetivos, os princípios, as finalidades do sistema, "de forma a auxiliar na interpretação teleológica e no efeito útil das normas" 245 . Segundo se acredita, o direito à identidade cultural como baliza das regras do direito internacional privado pode se prestar a importante papel no âmbito das relações paterno-filiais. Trata-se do direito que a criança tem, em meu entender, de conviver com culturas diferentes em todas as hipóteses em que sua família, inclusive a alargada, encontrar-se dispersa pelo mundo. Nesse sentido, a construção de Erik Jayme aparece, acredito, como abertura para a aplicação das normas do direito internacional privado

\footnotetext{
${ }^{242}$ Foi o que aconteceu no caso citado por JAYME. Identité culturelle..., cit., p. 254-255, em que as cortes alemãs deixaram de aplicar a lei local para aplicar a lei camaronesa justamente por considerar que havia, na hipótese fática, maior proximidade cultural dos envolvidos.

${ }^{243}$ Acerca do direito internacional privado muçulmano e sua correlação com o conflito de civilizações ou de culturas, veja-se GANNAGÉ. La hiérarchie..., cit., p. 155 et seq.

244 JAYME. Identité culturelle..., cit., p. 255.

${ }^{245}$ MARQUES; CACHAPUZ; VITORIA. Igualdade..., cit., p. 16.
} 
enquanto direito que tem tolerância pelo que lhe é estranho ${ }^{246}$, tolerância essa que vem indicada no sistema pela construção de normas narrativas.

Por fim, uma palavra acerca da tendência verificável, mormente em algumas recentes convenções assinadas no âmbito da Conferência da Haia de Direito Internacional Privado, no sentido de dotar o sistema de direito internacional privado convencional de normas materiais uniformes. Françoix Rigaux entende tratar-se de uma das mais notáveis evoluções dos trabalhos da Conferência da Haia o recurso a diversificadas técnicas jurídicas - que cuida de analisar e listar - que recorrem à elaboração de normas com conteúdo material, visando a certa uniformização das decisões em casos plurilocalizados. Assim, os reflexos que tais normas geram no sistema de atribuição da guarda e suas conseqüências merece atenção, mormente em tais convenções, objeto de análise no capítulo IV da tese, com vistas à correta comparação com o sistema nacional, analisado no capítulo III.

\section{CONTEÚDO DA RELAÇÃO FAMILIAR E REFLEXOS NA CONCEPÇÃO DO MÉTODO DO DIREITO INTERNACIONAL PRIVADO: TOMADA DE POSIÇÃo TEÓRICA E PRAGMÁTICA}

No Brasil, as tentativas de se proceder à abertura do sistema legislado de direito internacional privado malograram, permanecendo o país preso ao sistema das hard-andfast Rules. Assim, relativamente ao direito internacional privado brasileiro, pode-se afirmar que, no que tange à lei aplicável para reger a atribuição da guarda de filhos, nosso sistema contempla norma de caráter fixo e rígido a ser construída no terceiro capítulo da tese. É bem verdade que o princípio do melhor interesse da criança - tipificado na Convenção sobre os direitos da criança, de 1989 - poderia representar a válvula de escape para o julgador, que decidiria aplicar lei diversa daquela determinada pela regra rígida, construída com base na Lei de introdução ao código civil, caso pudesse vislumbrar em tal mecanismo situação que beneficiasse a criança e seus interesses ${ }^{247}$. Isso permitiria garantir à criança a

\footnotetext{
${ }^{246}$ DOLINGER. Da dignidade..., cit., p. 115.

${ }^{247}$ Outro não é o posicionamento de BORRÁS RODRÍGUEZ. El "interes del menor"..., cit., p. 940, quando afirma: "Si se utilizan normas de conflicto, la protección del menor se alcanza mediante el establecimiento y articulación de las conexiones. Así, el juego de una o de varias conexiones de forma alternativa o subsidiaria puede hacer prevalecer un interés prioritario. Por otra parte, la inclusión de una conexión
} 
efetivação da justiça conflitual na exata medida em que lhe seria "atribuída uma lei pessoal própria, uma lei que seja determinada em função de condições relativas à sua pessoa e não à pessoa" ${ }^{248}$ dos pais. Por outro lado, caso a lei dos pais fosse a lei mais indicada para regular a situação, por garantir um grau mais elevado de proteção aos interesses da criança $^{249}$, o princípio não afastaria a aplicação de tal lei, pois o que visa é a realização da justiça material e o fato de a ele se dar aplicação no âmbito do direito conflitual será sempre um passo naquela direção.

Nesse sentido, o princípio do melhor interesse da criança poderia fazer as vezes de cláusula geral de exceção a que acima se fez referência. Defende-se esse ponto de vista, mormente por decorrer o princípio do melhor interesse da criança de norma de origem internacional que visa a proteção dos direitos humanos da criança e do adolescente.

Acreditando que a Constituição Federal atribuiu, por força já dos $\S \S 1^{\circ}$ e $2^{\circ}$ do art. $5^{\circ}$, força supra-legal e aplicabilidade direta no sistema brasileiro aos tratados de direitos humanos, sendo desnecessária e até temerosa a inclusão do $\S 3^{\circ}$ ao mesmo art. $5^{\circ}$ da Carta constitucional, mas ciente da possibilidade de refutação de tal crença, busca-se argumento meramente pragmático para defender a aplicabilidade do princípio do melhor interesse da criança em detrimento da norma rígida construída com esteio na Lei de introdução, recorrendo-se ao critério cronológico - o mais tênue entre todos, como é cediço - para lembrar que a Convenção de 1989 foi ratificada em 1990, muitos anos depois de promulgado o Decreto-Lei de 1942 que revogou a Introdução ao código civil de 1916. Levantar-se-á, todavia, por parte de uma visão mais conservadora, objeção para informar que a Lei de introdução ao código civil traz regras de sobredireito que, como dito acima, possuiria "natureza superior às regras materiais" 250 . Enfrentar o problema desse modo é esquivar-se da função primordial que o sistema atribui aos órgãos incumbidos da tomada de decisões, todavia. Como salienta Moura Ramos, "le juge sera donc obligé de faire figure de législateur, en vue de concrétiser le principe dans la situation donnée"251.

Acredita-se que a adoção de tal método é salutar, mormente em período histórico como o que se vivenciou recentemente em que o próprio direito material sofreu influências

flexible puede dar mayores posibilidades de asegurar dónde se encuentra el verdadero interés del menor, aún a riesgo de una mayor inseguridad".

${ }^{248}$ FERRER CORREIA. Principais interesses..., cit., p. 85; FERRER CORREIA. O método..., cit., p. 7.

${ }^{249}$ Como lembra BORRÁS RODRÍGUEZ. El "interes del menor"..., cit., p. 928-929.

${ }^{250}$ MOURA RAMOS. Direito..., cit., p. 27-28.

${ }^{251}$ MOURA RAMOS. Les clauses..., cit., p. 314. 
benéficas de uma concepção filosófica que permitiu a inscrição de cláusulas abertas na legislação, ao mesmo tempo em que se viram diminuir as fronteiras lógico-didáticas levantadas para separar os ramos público e privado do saber jurídico. Nada mais coerente parece - que dotar o direito internacional privado da família, especificamente no que concerne às crianças, de mecanismo apto a garantir alguma forma de arejamento.

Como salienta Léna Gannagé, não basta para tal desiderato demonstrar - ou assumir como dogma - que uma norma internacional esteja situada em nível elevado da pirâmide normativa. Isso não se mostra suficiente para afirmar peremptoriamente sua primazia relativamente a normas inferiores. Assim, não basta assumir como verdade assente que o princípio do melhor interesse da criança tem status constitucional ou supra-legal capaz de derrogar a norma de direito internacional privado da lei de introdução, tecnicamente de hierarquia inferior, muito embora se possa defender a sua superioridade lógica como se fez no passado. Será necessário, ainda, demonstrar que:

"D'une part, la norma internationale doit pouvoir faire l'objet d'une application directe dans l'ordre interne. D'autre part, il doit exister une contrariété manifeste entre le norme internationale et la norme interne ${ }^{, 252}$.

O primeiro dos requisitos fica superado em face da ratificação da Convenção dos direitos da criança pelo Estado brasileiro. O segundo dos requisitos demanda a construção das normas interna e internacional para ver se, no que é fundamental, há contrariedade manifesta entre ambas. Acredita-se que haja. Se não no conteúdo, decerto naquilo que é essencial, ou seja, nos fins mesmos a que a norma de direito internacional privado se destina a garantir - a aplicabilidade do sistema jurídico mais afeto à situação fática, afetação essa que se afere por proximidade ${ }^{253}$. Resta ver se se conseguirá sustentar e defender tal concepção. A tentativa vem desenvolvida na segunda parte da tese.

${ }^{252}$ GANNAGÉ. La hiérarchie..., cit., p. 74.

${ }^{253}$ GANNAGÉ. La hiérarchie..., cit., p. 96-97 afirma que "il s'agit toujours, en effet, de s'affranchir de l'exigence de règles de conflit préétablies, pour déterminer, au vu d'une comparaison des différentes règles matérielles en présence, celle qui satisfait le plus aux exigences d'un principe général, en l'occurence, l'intérêt de l'enfant". 


\section{PARTE II}

A GUARDA DE FILHOS E SUAS CONSEQÜÊNCIAS

NO DIREITO INTERNACIONAL PRIVADO BRASILEIRO LEGISLADO E NO DIREITO INTERNACIONAL PRIVADO CONVENCIONAL 


\title{
A VERIFICAÇÃO DA LEI APLICÁVEL NO DIREITO INTERNACIONAL PRIVADO BRASILEIRO LEGISLADO
}

\begin{abstract}
SUMÁRIO: 1. Manutenção dos membros da família em território nacional: 1.1. Atribuição da guarda; 1.2. Direito de visita; 1.3. Alimentos; 1.4. Administração dos bens de filhos menores; 1.5. Exercício do poder familiar na desunião das famílias - 2. Separação transfronteiriça dos membros da família e exceções à aplicação do direito estrangeiro: 2.1. Atribuição da guarda; 2.2. Direito de visita; 2.3. Alimentos; 2.4. Administração dos bens de filhos menores; 2.5. Exercício do poder familiar na desunião das famílias - 3. Alteração posterior das situações fáticas: 3.1. Separação transfronteiriça dos membros da família que permanecia no mesmo território; 3.2. Reunião dos membros da família em território nacional.
\end{abstract}

O problema da guarda de crianças ganha contornos complicados quando a relação apresenta algum elemento de estraneidade ${ }^{254}$, normalmente representado pela residência de um dos pais em Estado diferente daquele em que a criança vive com o genitor que detém sua guarda, mormente se se atentar para o fato de que "importa no direito de família mencionar que os indivíduos têm um interesse forte no reconhecimento universal de suas relações jurídicas”, pois “a família não conhece fronteiras políticas”.

A hipótese mencionada anteriormente (residência no exterior) não é exclusiva, devendo o método próprio ao direito internacional privado ser convocado a atuar sempre que a relação jurídica paterno/materno-filial contar com qualquer elemento estrangeiro que conforme algum dos elementos de existência da relação jurídica. Daí por que a análise desse capítulo seja levada a cabo com base em duas realidades fáticas distintas, mas que apresentam reflexos de extrema importância na forma de exercício da guarda e no estabelecimento do direito de visitas, por exemplo.

${ }^{254}$ JAYME. O direito internacional..., cit., p. 27. 
Em um primeiro momento, então, em que pese a presença do elemento estrangeiro na conformação jurídica da relação, imagina-se a hipótese de que os pais da(s) criança(s) permaneçam domiciliados - ou residentes, como de hábito - em território brasileiro. Como o estabelecimento do domicílio ou da residência habitual da criança será feito pelo genitorguardião, percebe-se que a família, nessa hipótese, permanecerá "unida”, sem que se criem embaraços de monta para o exercício do direito de visitas, para o pagamento da pensão alimentícia fixada e para o exercício conjunto do poder familiar pelos pais que se separam. Da mesma forma, no que tange ao direito de administração dos bens dos filhos menores.

Sendo todos os membros da família parental residentes e domiciliados no País e permanecendo a família integrada sob a mesma soberania estatal após o pronunciamento da separação, do divórcio, ou do desfazimento da união estável entre os genitores havida $^{255}$, percebe-se que o elemento estrangeiro estará comumente presente, nessa hipótese, na nacionalidade de um ou de ambos os genitores ou, ainda, na nacionalidade da criança ou das crianças. Todavia, sendo o Brasil nação que preenche o conceito de lei pessoal com o recurso ao elemento de conexão domicílio, aplicável será, à hipótese, a lei nacional.

A segunda hipótese a que se dará atenção é aquela caracterizada pela separação transfronteiriça dos membros da família, quer porque se tenham separado de fato e ido, um deles, residir no exterior, seja porque um deles demonstra a intenção manifesta de deixar o território nacional a fim de fixar seu domicílio em país estrangeiro, seja, ainda, na hipótese

\footnotetext{
${ }^{255}$ O trabalho não visa determinar a lei aplicável para regular o desfazimento do casal conjugal, ou seja, das relações entre homem e mulher. Trata-se de questão anterior, já que, na normalidade dos casos, só se há falar em atribuição da guarda se os pais já não vivem mais juntos, ou, ainda, se juntos nunca viveram, quando a atribuição da guarda deve ser regulada desde o nascimento da criança, muito embora ambos os genitores conservem, entre si e mutuamente, o exercício do poder familiar. No que concerne à determinação da lei aplicável para regular a separação e o divórcio, conforme o caso, veja-se: AUDINET, E. Les conflits de lois en matière de mariage et de divorce. Recueil des Cours, Paris, v. 11, p. 171-252, 1926, p. 217 et seq.; CHESHIRE, Geoffrey Chevalier. The concept of marriage and the relations between husband and wife. Recueil des Cours, Leyde, v. 108, p. 115-188, 1963, p. 160 et seq.; SCHWIND, Fritz. Le divorce en droit international privé. Recueil des Cours, Leyde, v. 117, p. 445-502, 1966; MARQUES. O direito..., cit.; TANAKA. $O$ divórcio..., cit.; VALLADÃO, Haroldo. Conséquences de la difference de nationalité ou de domicile des époux sur les effets et la dissolution du mariage. Recueil des Cours, Leyde, v. 105, p. 69-172, 1963; VILLELA, Anna Maria. Le droit international privé brésilien et la question du divorce. Revue Critique de Droit International Privé, Paris, v. 69, n. 2, p. 231-278, 1980. Quanto à dissolução das uniões estáveis em direito internacional privado: GAUTIER, Pierre-Yves. Les couples internationaux de concubins. Revue Critique de Droit International Privé, Paris, v. 80, n. 3, p. 525-539, 1991; DOLINGER, Jacob. A família no direito internacional privado: casamento e divórcio. São Paulo/Rio de Janeiro: Renovar, 1997. Relativamente a ambas as hipóteses e com esteio em interessante análise de conflito cultural entre os membros do casal que se separa: GAUDEMET-TALLON, Hélène. La désunion du couple en droit international privé. Recueil des Cours, Dordrecht/Boston/Lancaster, v. 226, p. 9-280, 1991.
} 
de se requerer a inversão da guarda outrora atribuída, a majoração ou a diminuição da verba alimentícia fixada, a regulação do direito de visitas por forma diferente da que vigente, seja, por fim, pela dificuldade prática que esta realidade fática cria para o exercício conjunto do direito-dever de administrar os bens dos filhos menores e do poder familiar. Nesse caso, de maior complexidade, avultam as hipóteses de que o direito aplicável possa ser o estrangeiro, fazendo-se necessária a análise de possibilidades referenciadas à aplicação dos princípios que autorizam o afastamento da lei alienígena, preferindo-se, naquele caso concreto, a aplicação do direito nacional.

Por fim, ciente de que as relações fáticas nessa seara são extremamente volúveis em razão da garantia de direitos como a liberdade de ir e vir e o corolário de se fixar o domicílio em território estrangeiro, além do direito ao trabalho e o direito às convivências familiar e comunitária sadias, o trabalho procura imaginar algumas hipóteses em que a modificação das circunstâncias subjacentes à relação pode determinar nova conexão da realidade fática, dessa vez com ordenamento jurídico diverso daquele que regia, por aplicável, as relações familiares. Trata-se do chamado conflito móvel, caracterizado pela lícita alteração da circunstância de conexão, forçando à aplicação ao caso, que vinha sendo encarado segundo dada lei, de lei outra, indicada pela nova circunstância fática.

\section{MANUTENÇÃO DOS MEMBROS DA FAMÍLIA EM TERRITÓRIO NACIONAL}

Como já se adiantou, todo esse primeiro tópico do presente capítulo pode ser resumido na seguinte realidade: a manutenção de todos os familiares da criança no mesmo território - no caso, o território nacional - implica o reconhecimento de que o domicílio de todos os envolvidos esteja fixado em território brasileiro ${ }^{256}$. Como a qualificação da questão impele

\footnotetext{
${ }^{256}$ O que não impede a existência de elementos estrangeiros diversos ao domicílio na relação fática. Afastase, assim, as relações puramente internas, segunda a classificação de Jitta, mas não, em alguns casos urgentes, as relações relativamente internacionais, ou seja, aquelas relações que, sendo puramente internas à luz de dado ordenamento, quando enfrentadas por um juiz brasileiro, apresentam apenas elementos estrangeiros, todos eles referentes a um único ordenamento (pense-se na situação de uma criança japonesa, filha de japoneses, todos domiciliados e residentes habitualmente no Japão que venha a perder, por fatalidade, ambos os genitores no Brasil, durante viagem de férias, em razão de um acidente e a quem seja necessário atribuir um guardião, ainda que temporário). A respeito da classificação de Jitta: MARQUES DOS SANTOS, António. Direito internacional privado. In: MARQUES, Claudia Lima; ARAUJO, Nadia de. O novo direito internacional: estudos em homenagem a Erik Jayme. Rio de Janeiro: Renovar, p. 29-55, 2005, p. 29 et seq.
} 
ao reconhecimento de que se trata de relação atinente ao direito de família, busca-se na legislação nacional o elemento de conexão ao qual o legislador brasileiro de 1942 deu prevalência e conclui-se, sempre, pela aplicação da lei brasileira.

Assim, enquanto perdurar essa realidade fática (veja-se, a respeito das modificações nos fatos, o tópico 3), toda a regulação da guarda e de suas conseqüências será presidida pela aplicação da lei brasileira, uma vez que não se encontre presente o principal aspecto formulador de problemas nessa seara, a saber, a separação transfronteiriça dos membros da família, que dificulta o exercício do direito de visita e de outros direitos correlatos.

A escolha do elemento de conexão domicílio, nesse caso, facilita a determinação da lei a ser aplicada justamente porque a manutenção de todo o grupo familiar no mesmo território afasta qualquer forma de conflito entre os elementos de conexão eventualmente aplicáveis. Explique-se. O legislador do direito internacional privado brasileiro tem sido extremamente conciso desde a estatuição da Introdução ao Código Civil de 1916, que vigorou entre $1^{\circ}$ de janeiro de 1917 e 4 de setembro de 1942, permanecendo inalterada a sua atuação desde então ${ }^{257}$. A opção pelo sistema sintético de elaboração normativa no que concerne ao direito internacional privado acaba, por vezes, criando certa dificuldade no que respeita à determinação da lei pessoal familiar, seja a lei da nacionalidade (1916), seja a lei domiciliar (1942). Com efeito, a opção do legislador nacional foi sempre no sentido de estabelecer uma regra geral acerca das relações familiares e, a partir de 1942, uma série de regras específicas atinentes, em grande medida, às relações entre os cônjuges, negligenciando as relações filiais, que restaram entregues à apreciação da doutrina que lhes tentou privilegiar.

Ressalte-se, entretanto, que o Esboço de Teixeira de Freitas, em 1860, e o Projeto de Código de Aplicação das Normas Jurídicas, de Haroldo Valladão, em 1964, procuraram estabelecer um regramento relativamente minucioso e analítico das relações familiares, considerando, em parte, a construção doutrinária até então existente ${ }^{258}$.

O principal problema decorrente dessa opção legislativa oficial no que concerne às relações parentais dizia respeito, à luz da Introdução ao Código Civil de 1916, à

\footnotetext{
${ }^{257}$ DOLINGER, Jacob. A criança no direito..., cit., p. 385, classifica o produto da atuação do legislador brasileiro como lacônica.

${ }^{258}$ VALLADÃO, Haroldo. Développement et intégration du droit international privé, notamment dans le rapports de famille (cours général de droit international privé). Recueil des Cours, Leyde, v. 133, p. 413528,1971, p. 505 e 507.
} 
possibilidade de que os genitores portassem nacionalidades distintas ${ }^{259}$, o que dificultava o trabalho de exegese, a fim de se buscar a norma que seria aplicada, ora privilegiando-se a lei da nacionalidade do varão, ora pondo-se em destaque a lei nacional do cônjuge virago, ora, ainda, buscando-se a lei nacional da criança, conforme fosse o caso de se dar prevalência a um ou outros dos personagens envolvidos ${ }^{260}$. Diante desse verdadeiro conflito de nacionalidades, muitas vezes optava-se pela lei da nacionalidade do marido, já que ocupava a chefia da entidade familiar ${ }^{261}$. No entanto, nos casos de desquite então admitidos, desfeita a sociedade conjugal, destituído da chefia da família estaria ele, sendo necessário, por isso, buscar um critério subsidiário. Saliente-se que o art. $9^{\circ}$ da Introdução referida estabelecia critério de resolução de conflitos positivos e negativos de nacionalidade. Todavia, a regra ali assentada tratava do conflito meramente pessoal, em que o sujeito abrangido pela hipótese fática fosse apátrida (inc. I) ou ostentasse mais de uma nacionalidade, não havendo solução para tal conflito segundo as leis do país do nascimento e as do país de origem (inc. II), determinando-se a aplicação da lei do domicílio do indivíduo ${ }^{262}$.

Nesse sentido, havendo conflito de nacionalidade entre marido, mulher e criança, a doutrina dividiu-se entre vários critérios de solução para as várias hipóteses fáticas que demandassem aplicação eventual do direito estrangeiro, como se verá nas subdivisões do presente tópico.

A alteração do critério de conexão, em 1942, fazendo prevalecer a lei do domicílio ${ }^{263}$, pareceu pôr fim à questão conflituosa, na medida em que se estabelecia como regra que a

${ }^{259}$ MAYER. Évolution..., cit., p. 448. Na América Latina, a nacionalidade do marido nunca se estendeu à mulher nem aos filhos. Cf. VALLADÃO. Développement..., cit., p. 509.

${ }^{260}$ Optava por esse elemento de conexão o direito internacional privado dos então países socialistas, em que era comum o tratamento das mais diversas relações entre pais e filhos sob uma mesma rubrica, submetida, quase sempre (porém dependendo dos tratados bilaterais analisados), à lei da nacionalidade da criança. Cf. SOŚNIAK, Mieczyslaw. Les conventions conclues entre les pays socialistes sur le droit civil international et le droit international de la famille. Recueil des Cours, Leyde, v. 144, p. 1-76, 1975, p. 48.

${ }^{261}$ Desse modo nos sistemas jurídicos de direito muçulmano. Cf. BENATTAR, Raoul. Problèmes relatifs au droit international privé de la famille dans le pays de droit personnel. Recueil des Cours, Leyde, v. 121, p. $1-112,1969$, p. 102-103.

262 "Per individuare quale sia la legge applicabile al minore pluricittadino si dovrebbe anzitutto determinare la residenza familiare, il domicilio o la residenza del genitore naturale." FIORAVANTI, Cristiana. Rapporti di famiglia e ricerca di collegamenti "complementari" o "sussidiari" nel diritto internazionale privato italiano. Rivista di Diritto Internazionale Privato e Processuale, Padova, v. 24, n. 4, p. 675-690, 1988, p. 683.

${ }^{263}$ Sobre as vantagens atuais do velho critério manciniano de aplicação da lei nacional nos quadros atuais do direito internacional privado da família, por privilegiar a identidade cultural, veja-se: JAYME. Diritto di famiglia..., cit., p. 300, quando afirma: "in effetti, il vecchio principio manciniano di nazionalità si rileva più adatto alle attuali esigenze di protezione dell'identità culturale della persona rispetto al principio dell'applicabilità della legge del domicilio, sempre nell'ambito del diritto di famiglia". 
fixação do domicílio da família incumbiria àquele que, à época, era tido como seu chefe (art. $7^{\mathrm{o}}, \S 7^{\mathrm{o}}$ da LICC) ${ }^{264}$. Ocorre, todavia, que a evolução social experimentada acabou retirando do homem a primazia para a determinação do primeiro domicílio familiar ${ }^{265}$, devendo este ser fixado de comum acordo com a mulher. Se formalmente essa igualdade entre os cônjuges só foi atingida com a Constituição de 1988, fato é que essa proposição é mais antiga e condizente já com a evolução social vivenciada. Nesses termos, aliás, o posicionamento de Haroldo Valladão, ao comentar sua preocupação com as disposições conflituais de direito de família em seu Anteprojeto:

"Notre orientation actualisée, objective et constructive fut celle de donner au DIP du droit de la famille un contenu humain et social, égalisant les droits et devoirs des époux et des parents et enfants avec priorité pour ces derniers, et abandonnant les principes absolus et radicaux de loi nationale et loi du domicile, présentant d'autres solutions" 266 .

A possibilidade de que os genitores mantenham domicílios ou residências diversos, mesmo durante o casamento ou a união fática, faz necessária a escolha de um elemento de conexão subsidiário, complementar e neutro a que Valladão chamou de lei própria à família, que possa regular a totalidade das relações havidas pelos membros do grupo entre si, o que se justifica por "l'unité de la famille" que "demandait un élément de connexion situé audessus des éléments de connexion propres à chacun de ses membres"267.

A proposição de Valladão, então, recai sobre a lei do domicílio conjugal para os casos de famílias plurinacionais; a lei da residência habitual comum para as famílias pluridomiciliadas e, em casos esporádicos, a lei nacional, a lei do domicílio, a lei da residência do interessado que coincidisse com a lei do foro, seja do nacional, do domiciliado ou do residente no mesmo Estado do foro ${ }^{268}$. Tanto assim é, que o art. 41 de

\footnotetext{
${ }^{264}$ O que levou TENÓRIO. Direito internacional..., v. 2, cit., p. 153, a afirmar que "a opinião de que devemos observar a lei do filho não corresponde mais ao direito constituído", já que "o domicílio do filho é, por lei, o do pai”, o que impede a possibilidade de discordância entre as legislações.

${ }^{265}$ Segundo DOLINGER. A criança no direito..., cit., p. 211, nota 84, dispunha o "artigo 233, III do Código Civil de 1916 que compet[ia] ao marido o direito de fixar o domicílio da família, ressalvada a possibilidade de recorrer a mulher ao juiz, no caso de deliberação que a prejudi[casse]. Naturalmente que ao decidir sobre o domicílio independente da mulher, o juiz também julgará com quem ficarão os filhos menores. Outrossim, a regra só dá ao marido o direito de fixar o domicílio (com a ressalva do recurso da mulher ao juiz) mas não lhe faculta mudar o domicílio; se a mulher não concordar com a mudança, terá direito de permanecer no domicílio originalmente fixado para a família, ficando os filhos em sua companhia”.

${ }^{266}$ VALLAD ̃̃O. Développement..., cit., p. 507-508.

267 VALLADÃO. Développement..., cit., p. 509. A mesma idéia aparece em PINHEIRO, Luís de Lima. Direito internacional privado. Reimpr. da 2. ed. Coimbra: Almedina, 2005, v. 2, p. 305.

${ }^{268}$ VALLADÃO. Développement..., cit., p. 509.
} 
seu Projeto de Código de Aplicação das Normas Jurídicas propunha como lei cabível a que fosse mais favorável à criança, havendo conflito entre as leis da nacionalidade, do domicílio e da residência do pai, da mãe ou da própria criança.

Por fim, o Projeto de Lei do Senado nº 269, de 2004, dispõe:

Art. $8^{\circ}$ Estatuto pessoal - A personalidade, o nome, a capacidade e os direitos de família são regidos pela lei do domicílio. Ante a inexistência de domicílio ou na impossibilidade de sua localização, aplicar-se-ão, sucessivamente, a lei da residência habitual e a lei da residência atual.

Parágrafo único. As crianças, os adolescentes e os incapazes são regidos pela lei do domicílio de seus pais ou responsáveis; tendo os pais ou responsáveis domicílios diversos, regerá a lei que resulte do melhor interesse da criança, do adolescente ou do incapaz.

Percebe-se, claramente, o avanço legislativo a ser promovido com eventual aprovação desse projeto, pois ele faz submeter ao melhor interesse da criança a lei a ser aplicada. Trata-se de princípio reitor do direito internacional dos direitos humanos, no que se refere aos direitos infanto-juvenis ${ }^{269}$.

\subsection{Atribuição da guarda}

Para a atribuição da guarda, levará o juiz em consideração a lei vigente no domicílio da família, imaginando-se haver identidade entre as leis pessoais de todos seus membros. Na hipótese aventada neste item, como se deixou assentado, é o que se passa. Nesse caso, não só os pais e a criança mantêm seu domicílio em um mesmo território soberano, como têm a intenção manifesta de permanecer, senão perpetuamente, certamente em médio espaço de tempo, ostentando o mesmo domicílio estatal. Obviamente, o domicílio que se considera aqui é aquele estabelecido com referência a um Estado soberano ou, quando muito, a um ente estadual que, mesmo dispondo de legislação autônoma ${ }^{270}$, se submeta à soberania de um ente que lhe é superior, e não ao domicílio extremamente particularizado a que os portugueses fazem referência como sendo a morada da pessoa, de que se fornece endereço individualizado. Somente com essa ressalva é que será possível entender a afirmação de que os pais separam as suas vidas, cabendo a um deles a detenção da guarda de seus filhos,

${ }^{269}$ Como já se teve a oportunidade de defender, na dissertação de mestrado. MONACO. A proteção..., cit.

${ }^{270}$ Trata-se, assim, de um Estado com ordem jurídica plurilegislativa. A respeito: BORRÁS, Alegría. Les ordres plurilégislatifs dans le droit international privé actuel. Recueil des Cours, Dordrecht/Boston/Lancaster, v. 249, p. 145-368, 1994. 
e que, ainda assim, o domicílio permanece inalterado. Claramente, as moradas se tornarão independentes com a separação do casal, podendo mesmo ocorrer de o casal passar a residir em cidades ou estados federados distintos, determinando um afastamento do nãoguardião e sua prole, mormente em país de extensão continental como é o caso do Estado brasileiro, em que o deslocamento dos indivíduos torna-se dificultado, algumas vezes, em função de uma série de fatores.

Mantendo-se todos domiciliados em um mesmo território, terão o mesmo domicílio. Resta, portanto, saber se a lei brasileira será aplicável por consistir na lei do domicílio dos pais ou se será aplicada por estar afeta ao domicílio da criança. Há, ainda, a possibilidade de que sua aplicação se esteie no fato de ser a lei da família, como queria Valladão. A questão, despida de interesse prático nesse caso, apresenta, no entanto, forte interesse teórico. Com efeito, a razão subjacente à aplicação da lei brasileira nesse caso será a que indicará a possível solução da mesma hipótese no caso de os genitores e a criança apresentarem domicílios diversos, porquanto a aptidão para que se mostre como a lei mais favorável à criança poderá depender dessa razão subjacente.

Assim, se a aplicação da lei nacional se dever ao fato de ser a lei do domicílio dos pais da criança, persistirá a dificuldade de se escolher a lei aplicável em casos outros em que pai e mãe vivam em territórios nacionais distintos, separados de fato, por exemplo. Por outro lado, justificar no caso a aplicação da lei brasileira com a idéia de que se trata da lei unitária da família, se oferece a vantagem de utilizar um critério tendencialmente neutro, apresenta a desvantagem relativa à família unitária que não mais prevalecerá após a separação, o divórcio ou a dissolução da união estável. Da mesma forma, nas hipóteses em que os pais nunca tenham manifestado a intenção de constituir uma família, mas tendo tido um filho cuja guarda é necessário regular, mostrar-se-á como um critério vazio e despido de razão, dada a nova conformação da sociedade brasileira, em que não cabe qualquer forma de discriminação relativamente à criança. Assim, se a lei for aplicada por ser a lei da família, onde não houver família em sentido estritamente formal não haverá critério para a sua escolha.

De todo o exposto, parece que a melhor razão para a aplicação da lei brasileira, nessa hipótese em que o domicílio dos envolvidos coincide e continuará a coincidir, é mesmo a que tem em consideração o fato de a lei ser aquela que se encontra mais próxima à criança 
e, por isso, mais próxima para garantir a tutela de seus direitos ${ }^{271}$. Trata-se, no caso, da lei de seu próprio domicílio ${ }^{272}$, presumindo-se ser essa a lei que maior empenho demonstrará na efetivação do princípio do melhor interesse da criança e que, no que concerne à atribuição de sua guarda, diz não só com o sistema a ser escolhido (guarda simples, alternada ou compartilhada), mas também com a pessoa do guardião, que, como se viu, à luz do direito brasileiro atual será aquela que demonstrar possuir as melhores condições para o exercício da tarefa, seja o pai, a mãe ou terceiro, o que serve como argumento de reforço para que a lei brasileira seja aplicada porquanto lei pessoal (do domicílio) do infante ${ }^{273}$.

\subsection{Direito de visita}

Também no que concerne à temática do direito de visitação, permanecendo todos os membros do grupo familiar da criança domiciliados em território brasileiro, aplicável para regular tal exercício será a lei brasileira. Nesse caso, então, o genitor não-guardião terá acesso à criança segundo a cadência temporal estabelecida em acordo entre os pais ou determinada judicialmente pelo magistrado. A questão, aparentemente, não suscita maiores dificuldades.

Alguns aspectos, no entanto, devem ser postos em relevo. Primeiro, o direito de visitação deverá ser exercido no território nacional. Isso não impede, entretanto, que querendo o não-guardião viajar ao exterior acompanhado de sua prole, envide esforços no sentido de obter a necessária autorização para que as crianças possam deixar o País. Cabe ao guardião, em um primeiro momento, oferecer essa autorização, por escrito e com firma reconhecida, segundo o que dispõe o Estatuto da Criança e do Adolescente, em seu art. 84.

\footnotetext{
${ }^{271}$ FRANCHI, Marina. Protezione dei minori e diritto internazionale privato. Milano: Giuffrè, 1997, p. 48.

272 PONTES DE MIRANDA, Francisco Cavalcanti. La conception du droit international privé d'après la doctrine et la pratique au Brésil. Recueil des Cours, Paris, v. 39, p. 551-678, 1932, p. 635, propugna pela aplicação da lei pessoal da criança na hipótese: "C'est elle aussi [lei pessoal da criança] qui designe celui des parents à qui, en cas de divorce, d'absence ou de séparation de corps, la garde de l'enfant doit être confiée". O autor escrevia, no entanto, quando o elemento de conexão brasileiro era a nacionalidade.

${ }^{273} \mathrm{Na}$ Bélgica, em que o estatuto pessoal é preenchido pela lei da nacionalidade, a jurisprudência tem aplicado de ofício a lei da nacionalidade da criança para a regulação da guarda de jovens estrangeiros, a menos que tal aplicação mostre-se contrária ao interesse do infante, quando é afastada por ofensiva à ordem pública. Cf. RIGAUX, François. Le statut des mineurs, l'autorité parentale et les obligations alimentaires en droit international privé. Tijdschrift voor Privaatrecht, Belgique, v. 19, p. 311-326, 1982, p. 317-318. No caso do texto, como a lei do domicílio é a própria lei brasileira, não é possível afastá-la invocando ofensa à ordem pública, por óbvio.
} 
Não obstante, havendo recusa injustificada por parte do guardião, poderá o visitante requerer suprimento judicial ${ }^{274}$, que será concedido sempre que não houver fundado receio de que o requerente esteja intentando evadir-se do território nacional em companhia da prole que não tem em sua companhia diuturna. A causa do pedido, no entanto, pode ser lícita. Vai do simples desejo de mostrar outras culturas à prole, assegurando-lhe o direito à educação e ao saber cultural, até o que parece ser muito mais justificável: o desejo de levar o(s) filho(s) a seu país de origem, onde o não-guardião mantém família, fazendo-os conviver, ainda que por período diminuto, com avós, tios, primos etc. De todo conveniente, nesses casos, que o não-guardião procure deixar assentado no acordo ou na decisão judicial o seu direito de ter consigo a prole nas viagens que fará a sua terra natal, a fim de garantir o convívio das crianças com a família alargada ${ }^{275}$.

Há que se ter em mente, por fim, a possibilidade de que o guardião se evada do território nacional, carregando consigo a prole, para se estabelecer em outro país, impossibilitando que o não-guardião, que restará em território nacional, mantenha contato com seus filhos. A atuação dos guardiões, nesse caso, é ilícita, posto que também a eles é dirigida a norma do art. 84 do Estatuto da Criança e do Adolescente. Fazem-no, entretanto, no mais das vezes baseados na idéia de que a eles incumbe, com exclusividade, o direito de fixar o domicílio da criança.

São situações que, a par de dificultarem o correto exercício do direito de visitas por meio da subtração ilícita das crianças do local em que habitualmente se encontram - o que acarreta a ineficiência do sistema jurídico brasileiro, demandando mecanismos de cooperação internacional -, podem determinar uma modificação da situação fática vivenciada pela família da criança, o que será objeto de maiores considerações no item 3 , infra.

\footnotetext{
${ }^{274}$ VIEIRA, Francisco Xavier Medeiros. In: CURY, Munir (Coord.). Estatuto da Criança e do Adolescente comentado. Comentários jurídicos e sociais. 7. ed. São Paulo: Malheiros, 2005, p. 274.

${ }^{275}$ DOLINGER. A criança no direito..., cit., p. 215-216, menciona interessante caso em que cabia à mãe, guardiã, diligenciar para homologar o acordo que garantia ao pai o direito de ter consigo as crianças quando este fosse à Alemanha com esta finalidade. Na hipótese, a mãe acabou por omitir-se e quando o pai requereu a autorização para viajar, ela quis obstar a viagem, conseguindo atingir o seu intento. O principal fundamento da decisão estava em considerar as dificuldades que certamente se imporiam para que se conseguisse o cumprimento da eventual ordem judicial brasileira de regresso das crianças em tribunais de outros países.
} 


\subsection{Alimentos}

No que concerne à lei aplicável aos alimentos devidos aos filhos, estando credor e devedor domiciliados no mesmo território, será competente a lei brasileira para regular o quantum da prestação alimentícia, bem como os mecanismos para o seu estrito cumprimento $^{276}$. Os elementos de conexão geralmente indicados para reger a escolha da lei aplicável à matéria são a lei pessoal do devedor ${ }^{277}$ ou a do credor ${ }^{278}$, com certa preferência doutrinária e jurisprudencial por essa última, dada a situação de necessidade que atinge a criança alimentanda, razão pela qual haja quem defenda, com mais razão, a aplicação da lei mais favorável ao alimentando, seja ela a lei pessoal do devedor ou do credor $^{279}$.

Seja como for, estando todos os envolvidos domiciliados no território brasileiro nessa situação que se está a analisar, nenhuma consideração de monta merece ser feita, remetendo-se ao item 2.3, infra, para uma discussão mais aprofundada.

\subsection{Administração dos bens de filhos menores}

A administração dos bens dos filhos menores e, eventualmente, a constituição de usufruto temporário em favor dos pais, pendente a menoridade do titular do patrimônio, são direitos que se estabelecem como decorrência da incapacidade dos menores de idade, que não têm traços de maturidade necessários para administrar os seus próprios interesses, devendo, por isso, submeter-se à intervenção de seus pais, que prestarão, todavia, contas de sua administração no momento oportuno.

Pode-se discutir, todavia, se a regulação de tais fatos submete-se à lei pessoal da criança proprietária dos bens, justamente por ser decorrência de sua condição de incapaz, ou à lei da situação dos bens, entendendo-se, nessa última circunstância, que a instituição

\footnotetext{
${ }^{276}$ Veja-se a respeito, porém com extrema impropriedade técnica e profundo desconhecimento do que seja o direito internacional privado, FACHIN. Dever alimentar..., cit., em especial às p. 66-76.

277 BENATTAR. Problèmes..., cit., p. 104-105; KATIČIĆ, Natko. Le droit international privé dela Yougoslavie dans le domaine des rapports familiaux et successoraux. Recueil des Cours, Leyde, v. 131, p. 393-488, 1971, p. 447. Entre nós: PEREIRA, Luís Cezar Ramos. Prestação de alimentos no direito internacional privado brasileiro. Revista dos Tribunais, São Paulo, ano 82, v. 690, p. 29-38, 1993, p. 35, para quem tal solução facilita a execução da condenação no Estado do devedor.

${ }^{278}$ PONTES DE MIRANDA. La conception..., cit., p. 636; VICENTE, Dário Moura. Direito internacional privado - ensaios. Coimbra: Almedina, 2002, v. 1, p. 84.

${ }^{279}$ Assim o Projeto de Haroldo Valladão, art. 43. VALLADÃO. Développement..., cit., p. 509-510. CASTRO. Direito internacional..., cit., p. 419.
} 
da administração e do usufruto, ou de apenas um entre eles, é conjuntura que se estabelece em razão do próprio bem, que necessita, para cumprir sua função social, de alguém que os administre e/ou usufrua.

Lucienne Topor afirma que a razão principal seria garantir a dissociação pessoal entre o guardião da criança e o administrador do seu patrimônio, dificultando que as atribuições recaiam sobre a mesma pessoa ao se escolherem elementos de conexão diversos para as situações em apreço ${ }^{280}$. Não é possível concordar que essa razão seja invocada como efetiva, pois depende mais, ao que parece, da sorte e da distribuição dos bens, sendo impossível garantir, logo à primeira vista, que o objetivo perseguido possa ser atingido. Daí por que se tenha tentado encontrar outro fundamento para a opção legislativa, mais condizente com a despatrimonialização das relações familiares, valor assente no ordenamento brasileiro.

Assim, se a qualificação se der em favor dos bens e de sua função social, entender-se-á que a lei aplicável é a lei da situação dos bens, fazendo o legislador uso do elemento de conexão locus rei sitae para determinar a regulação dos bens imóveis, e da lei domiciliar para a regulação dos bens móveis ${ }^{281}$. É o que ocorre, por exemplo, nos países de common $\operatorname{law}^{282}$ e foi o critério seguido pelo Congresso de Montevidéu, em 1888 e 1889, relativamente aos bens imóveis ${ }^{283}$.

Todavia, se a opção se fizer pelo reconhecimento de que a administração e/ou o usufruto dos bens dos menores de idade são instituídos em favor dos mesmos, pendente a causa de sua incapacidade até o implemento de sua maioridade, dever-se-á aplicar a lei pessoal da criança proprietária, lei que, na hipótese que se está a versar, será sempre a brasileira $^{284}$. Nesse sentido, a qualificação empreendida leva em consideração a razão pela qual se estabelecem a administração dos bens de propriedade da criança e a constituição de eventual usufruto concluindo tratar-se da necessidade de proteção da própria criança e de

\footnotetext{
${ }^{280}$ TOPOR, Lucienne. Les conflits de lois en matière de puissance parentele. Paris: Dalloz, 1971, p. 294.

281 "Il faut entendre par loi réelle, la loi de la situation effective en ce qui concerne les immeubles et la loi de la situation fictive, c'est-à-dire celle du domicile de l'enfant mineur, en ce qui concerne les meubles". TOPOR. Les conflits..., cit., p. 294, nota 2, citando Wolff e Dicey and Morris.

282 TENÓRIO. Direito..., cit., p. 153-154.

${ }^{283}$ CASTRO. Direito..., cit., p. 412-413. O autor parece concordar com essa opção.

${ }^{284}$ Assim parece entender, pessoalmente, TENÓRIO. Direito..., cit., p. 154, ao afirmar ser este o critério da lei francesa. No mesmo sentido, no que se refere à lei belga: GANSHOF, Louis F.; BUGGENHOUT, Christian van. La protection des biens des mineurs dans les relations internationales. Revue Belge de Droit International, Bruxelles, v. 15, n. 1, p. 149-164, 1980; RIGAUX. Le statut..., cit., p. 317.
} 
seu patrimônio ${ }^{285}$, fazendo cisão entre a figura do pai e da mãe e dos administradores ainda que, na prática, a situação indique identidade real entre as pessoas que exercem tais funções. Parece, efetivamente, ter sido essa a opção do legislador brasileiro (lex fori $)^{286}$ ao regulamentar o instituto em seara estritamente protetiva dos interesses da criança, na medida em que o usufruto exercido por seus pais, bem como a administração por eles realizada, devam se fazer com vistas no interesse presente dos incapazes, qual seja, o de que os frutos percebidos por seus pais, detentores do poder familiar, possam reverter, ainda que indiretamente, em seu favor, bem como no seu interesse futuro, que é o de receber seus bens desimpedidos de ônus de qualquer espécie.

Conseqüência da opção qualificadora aqui seguida e da escolha da lei pessoal do proprietário para regular o usufruto e a administração dos bens dos filhos menores por seus pais, enquanto detentores do poder familiar, é a submissão às disposições da lei brasileira de todos os atos de alienação e imposição de gravames relativos aos bens de propriedade da criança.

\subsection{Exercício do poder familiar na desunião das famílias}

A lei aplicável ao exercício do poder familiar no caso de desunião das famílias deve ser a lei pessoal do incapaz, que, como já se repisou, no caso do sistema brasileiro é a lei do domicílio da criança. Quer isso significar que essa lei irá determinar a quem incumbirá exercer tal poder-dever, verdadeiro munus público, e por que forma, ou seja, se por meio de representação, indicando a lei, em consequiência, a idade em que a criança adquirirá a capacidade relativa, ou assistência, indicando-se a idade em que se adquire a plena capacidade, fazendo-se cessar o poder familiar ex lege. Além disso, a mesma lei determinará as hipóteses em que a criança poderá ser emancipada, extinguindo o poder familiar pela vontade dos envolvidos ${ }^{287}$.

Também é a lei em que a criança é domiciliada, qualquer que seja a sua nacionalidade,

\footnotetext{
${ }^{285}$ Nesse sentido: BOXSTAEL, Jean-Louis van. L'administration de la personne et des biens des incapables. In: VERWILGHEN, Michel; VALKENNER, Roland de. Relations familiales internationales. Bruxelles: Bruylant, p. 191-234, 1993, p. 222.

${ }^{286}$ Caso se entendesse que a razão estaria na necessidade de administração dos bens e sua fruição, como forma de cumprimento de sua função social, dever-se-ia ter em mente a determinação normativa brasileira no sentido de que a qualificação far-se-ia lex causae, ou seja, segundo a lei da situação efetiva ou ficta dos bens imóveis e móveis, respectivamente.

${ }^{287}$ PONTES DE MIRANDA. La conception..., cit., p. 635.
} 
a competente para regular as hipóteses de suspensão e perda do poder familiar, porquanto o interesse subjacente nesses casos seja o do infante, no sentido de ser liberado de situações nocivas ao seu pleno desenvolvimento físico, psíquico e social e como a criança apresenta contato mais estreito com o país de seu domicílio ${ }^{288}$ - no caso do sistema brasileiro -, é natural que essa lei tenha sua competência reconhecida.

Situações prementes podem, no entanto, autorizar a tomada de medidas urgentes com apoio na lei do local em que a criança se encontra, aplicando-se, portanto, a lex fori, mesmo que o menor não tenha ali fixado seu domicílio nem apresente liame de nacionalidade relativamente àquele Estado, encontrando-se em seu território passageiramente $^{289}$. A razão subjacente parece ser a necessidade de se garantir a integridade de seus direitos em qualquer situação ${ }^{290}$, conforme determinam as convenções internacionais de direitos da criança, as quais inauguram a doutrina da proteção integral dos jovens em detrimento de outra forma de se pensar a questão - vigente no passado -, em que só se intervinha relativamente às crianças em hipóteses em que elas estivessem em situação tida como irregular ${ }^{291}$.

\section{SEPARAÇÃO TRANSFRONTEIRIÇA DOS MEMBROS DA FAMÍLIA E EXCEÇÕES À APLICAÇÃO DO DIREITO ESTRANGEIRO}

Por sua vez, a separação transfronteiriça dos membros da família e a conseqüente constatação de que os domicílios dos genitores são ou serão diversos dificulta a resolução da questão no que concerne à aplicação exclusiva do direito positivo brasileiro, porquanto

\footnotetext{
${ }^{288}$ Posicionando-se contrariamente à lei da nacionalidade da criança, CASTRO. Direito..., cit., p. 411, ao afirmar, com razão, ser intolerável para uma dada sociedade que leis diversas se apliquem a famílias diversas para regular as relações entre pais e filhos, porquanto se possa gerar a hipótese de pais estrangeiros exercerem "mais ampla autoridade sobre os filhos do que a permitida pelo direito local".

${ }^{289}$ TOPOR. Les conflits..., cit., p. 199-216; FRANCHI. Protezione..., cit., p. 52; KATIČIĆ. Le droit..., cit., p. 447-448.

290 “Ce n'est donc pas sans pertinence qu'on admettra la favorisation individuelle en matière familiale. Et il ne serait pas surprenant si, dans le cadre d'une réglementation basée sur l'application de la loi nationale ou d'autres lois subsidiaires, toujours catégorielles, se trouvaient des règles admettant le choix entre certaines lois selon le principe de la favorisation individuelle de l'enfant. (...) il est bien possible d'introduire, en toute conscience et pour le bien de l'enfant, la loi propre (la loi du for) en qualité de statut subsidiaire". KATIČIĆ. Le droit..., cit., p. 441-442.

${ }^{291}$ Em sentido contrário, parecendo entender que o fundamento para a tomada de medidas urgentes é mais o interesse da sociedade em que a criança se encontra do que o interesse da própria criança, CASTRO. Direito..., cit, p. 413, ao fazer assentar a situação na natureza das normas aplicáveis. Também: TOPOR. Les conflits..., cit., p. 204-205.
} 
este eleja como elemento de conexão, já referenciado, o domicílio das partes. Conseqüências disso são, de um lado, a possibilidade de que o sistema indique a aplicação do direito estrangeiro e, de outro, a existência de eventuais dificuldades para se atingir o conceito de lei mais favorável quando for admitida a comparação das leis potencialmente aplicáveis com o intuito de beneficiar a criança.

Nesse passo da pesquisa, então, poder-se-á tecer alguns comentários a respeito de eventuais hipóteses que autorizam o afastamento do direito estrangeiro em tese competente, sempre que sua aplicação pareça ofender a ordem pública nacional e sempre que seu chamamento seja devido a alguma forma de obtenção fraudulenta da determinação de aplicação do direito estrangeiro, o que é possível atingir pela modificação pré-ordenada de um elemento da relação jurídica, fazendo-a conectar-se a algum sistema estrangeiro que, de antemão, sabia-se representar o elemento de conexão eleito pela norma de direito internacional privado do foro. É que, não tivesse advindo a fraude, jamais ocorreria a aplicação da lei vigente no ordenamento estrangeiro indicado.

A intenção fraudulenta, portanto, reside exatamente na persecução de disposições que se mostrem mais benéficas aos interesses daquele que frauda a lei de direito internacional privado do foro. Dessa forma, sendo insuportável conviver com a situação lesiva ao ordenamento em si, o sistema determina que se releve a deslocação da lei competente. No entanto, como se procurará demonstrar, pode ocorrer que tal iniciativa mostre-se duplamente ardilosa. Primeiro, porque se faça recurso deliberado na alteração do elemento estrangeiro da relação. Finalmente, porque essa alteração poderá ser determinada justamente para que se tente forçar a aplicação da lei que se mostre mais favorável à criança, em sua essência. Pretende-se afirmar que, nas hipóteses em que as regras de direito internacional privado previrem a aplicação da lei mais benéfica à criança, eventual conduta ardilosa do genitor com a premeditada intenção de alterar o elemento da relação, fazendo-o ser colmatado por uma referência estrangeira atinente justamente ao regramento material mais benéfico à criança, deverá ser relevada pelo magistrado. Com efeito, parece que a previsão subsidiária do elemento de conexão lei mais favorável não admitirá a incidência da exceção de fraude à lei que, em que pese ser pena imposta à parte que age sorrateiramente, irá certamente ceder diante dos benefícios que o sistema imputado de forma fraudulenta poderá gerar para a regulação da situação jurídica da criança. Ademais, como se afirmou no capítulo II, supra, as exceções à aplicação do direito estrangeiro são 
substituídas pelos critérios flexíveis de conexão justamente por alcançarem a priori o resultado que normalmente só se atingiria a posteriori.

Já quanto à invocação da ordem pública ${ }^{292}$, insta deixar assente o fato de ser princípio de dificílima conceituação e precisão, encontrando incrível mobilidade no espaço e no tempo justamente por depender da verificação de certa filosofia político-jurídica imanente às legislações, reflexo da vontade básica e majoritária de cada nação ${ }^{293}$, vontade que acaba por refletir as necessidades de cada Estado, em determinada época ${ }^{294}$.

Essas necessidades que se refletem na vontade da maioria e restam consignadas nas leis de cunho material podem apresentar certa aproximação principiológica nos diversos Estados nacionais, e por vezes essa aproximação encontra mesmo assento na legislação de cada Estado. Isso se deve ao fato de que as sociedades (mormente as ocidentais) apresentam certa identidade cultural, ideológica, política e econômica, se bem que, apesar disso tudo, algumas diversidades radicais ${ }^{295}$ estejam presentes e impeçam a uniformização e a harmonização legislativas ${ }^{296}$.

Percebe-se, assim, que nem a vontade da sociedade é unânime quando do estabelecimento e da eleição de seus valores primordiais e fundacionais, nem essas vontades se mostram homogeneizadas no cotejo inter-fronteiras. Daí porque dizer-se que a “ordem pública nacional corresponde ao conjunto de valores imperativos que se encontram permeados no ordenamento jurídico e que devem preponderar no exercício da jurisdição" 297 .

Isso explica o recurso que o direito faz, em maior ou menor grau, à ordem pública

${ }^{292}$ As idéias expendidas até o início do tópico 2.1 tiveram origem na pesquisa publicada em MONACO, Gustavo Ferraz de Campos. A lei de introdução, O Código Civil de 2002 e seu enfoque espaço-temporal. In: HIRONAKA, Giselda Maria Fernandes Novaes (Coord.). Novo Código Civil: interfaces no ordenamento jurídico brasileiro. Belo Horizonte: Del Rey, 2004, p. 1-18.

${ }^{293}$ Mas nem sempre isso se passa dessa forma. Muitas vezes, "a ordem pública internacional é invocada como meio de defesa de uma política legislativa que não visa a tutela daqueles valores mas que é adoptada por motivos de oportunidade. A recusa de aplicação da lei estrangeira justifica-se aqui pelo receio de que a aplicação da norma contrária àquela política possa ter um efeito subversivo". FERRER CORREIA, António. Lições de direito..., cit., p. 409.

${ }^{294}$ DOLINGER, Jacob. A evolução da ordem pública no direito internacional privado. Tese apresentada à Congregação da UERJ para o concurso à Cátedra de Direito Internacional Privado, 1979, p. 4-5.

${ }^{295}$ TENÓRIO. Direito..., cit., v. 1, p. 321.

${ }^{296} \mathrm{~A}$ esse propósito, veja-se CASELLA, Paulo Borba. Modalidades de harmonização, unificação e uniformização do direito: o Brasil e as convenções interamericanas de direito internacional privado. In: CASELLA, Paulo Borba; ARAUJO, Nadia. Integração jurídica interamericana: as convenções interamericanas de direito internacional privado (CIDIPs) e o direito brasileiro. São Paulo : LTr, p. 77105, 1998.

${ }^{297}$ CASELLA, Paulo Borba. A ordem pública e a execução de cartas rogatórias no Brasil. Revista da Faculdade de Direito da Universidade de São Paulo, São Paulo. v. 98, p.563-571, 2003, p. 568. 
enquanto princípio guardião dos valores sociais, para se proteger de desmandos e arbitrariedades que possam ser cometidos em nome de princípios outros, como os da autonomia da vontade ou da comunhão internacional.

Esse maior ou menor grau em que se pode evocar o princípio da ordem pública permite concluir pela existência de uma tríplice nivelação para que a ele se recorra, como demonstra Jacob Dolinger, em obra já referida ${ }^{298}$. Tal forma de se entender o princípio em comento tem a especial vantagem de afastar uma série de distinções iníquas que a doutrina, ao longo dos tempos, foi estabelecendo ${ }^{299}$ para tentar explicar a força que a ordem pública tem de impedir não só a manifestação de posição discordante da vontade das partes em um negócio jurídico regulado de forma imperativa pela lei, mas também que a própria norma de direito internacional privado tenha aplicação. Nesse último caso, o juiz afastaria, em princípio, a lei estrangeira indicada por sua lei nacional como sendo a aplicável para a resolução do conflito.

Aquelas distinções doutrinárias relativas à força vinculante da norma têm sido muito criticadas nos últimos tempos.

Assim, de acordo com a nova formulação doutrinária, no primeiro nível a ordem pública (ou a vontade comum da nação) se levanta para impedir que a vontade individual das partes em um negócio jurídico possa prevalecer contra os interesses postos pela maioria. Ideal ou filosoficamente, uma ofensa à ordem pública desse tipo só poderia ser perpetrada pelo grupo minoritário, que foi derrotado no momento da positivação do direito, uma vez que a maioria, em tese, haveria de respeitar e acatar a sua própria vontade, submetendo-se à regulação do negócio imposta pela lei. Percebe-se, portanto, que a aplicação do princípio da ordem pública nesse primeiro nível é de caráter absolutamente interno, sem qualquer reflexo jurídico para além das fronteiras nacionais. Todavia,

\footnotetext{
${ }^{298}$ Também em DOLINGER, Jacob. A ordem pública internacional em seus diversos patamares. Revista dos Tribunais, São Paulo, v. 93, n. 828, p. 33-42, out. 2004, especialmente às páginas 33-37. Não confundir o conceito, entretanto, com o conceito de ordem pública mundial, posto ser o primeiro (em sua tríplice nivelação) de ordem interna, ao passo que o segundo é de origem verdadeiramente internacional, comum à comunidade jurídica internacional, podendo, por isso, ser "caracterizada como o interesse comum da Humanidade". Assim: DOLINGER, Jacob. Ordem pública mundial: ordem pública verdadeiramente internacional no direito internacional privado. Revista de Informação Legislativa, Brasília, v. 23, n. 90, p. 205-232, 1986, p. 210.

${ }^{299}$ Elucidativa é a passagem seguinte, com caráter de conclusão: "não sendo as leis propriamente ditas de ordem pública, não há como falar de leis de ordem pública interna e leis de ordem pública externa. Existe o princípio da ordem pública, algo abstrato que é aplicado às leis quando o juiz entender que determinada regra jurídica deve contar com a proteção, com o reforço desse princípio" (DOLINGER. A evolução..., cit., p. 40-41).
} 
justamente porque essa maioria referida pode ser alterada diante da evolução social, é possível que normas que não admitiam afastamento pela vontade das partes passem a ser afastadas, alterando-se seu caráter cogente. Nesse caso, não foi a lei que mudou, mas a ordem pública que a permeia que sofreu alteração ditada pelas necessidades sociais. No que concerne aos problemas que esta tese procura enfrentar, então, pode bem ser que o juiz, invocando o princípio da ordem pública, afaste eventual acordo de visitas lavrado entre os genitores a respeito da criança que preveja que as eventuais visitas serão realizadas exclusivamente em território nacional, impedindo, em razão disso, o convívio do infante e sua família alargada. E isso sempre que o juiz entender que o direito à convivência familiar, em sua acepção mais ampla, deve ser garantido e respeitado.

No segundo nível, no entanto, essa ordem pública ganha contornos internacionais. Sua aplicabilidade relaciona-se com a constatação de que a lei estrangeira indicada pela norma de direito internacional privado interna como sendo a lei aplicável para o deslinde da questão jurídica apreciada exprime valores muito diversos dos valores da sociedade nacional, motivo pelo qual sua aplicação incondicional poderia chocar os bons costumes, ou a soberania nacional. Trata-se de um grau mais elevado de aplicação do princípio (“de maior gravidade”, como refere Jacob Dolinger), justamente por implicar a não-aplicação de uma disposição legal nacional de direito internacional privado, em virtude da nãoaceitação do conteúdo da regulação legal estrangeira. Isso porque, como salienta o mesmo autor, em obra recentemente publicada no Brasil, "a lei que choca, que é incompatível, que escandaliza, esta lei é distante, foge completamente da idéia básica de proximidade, e por

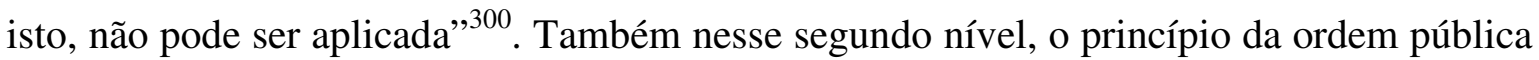
pode tornar-se maleável e mutável com o transcorrer do tempo. Assim, regulamentações de guardas foram estabelecidas, no passado, com a aplicação de normas estrangeiras que previam privilégio da mãe, o que não conflitava com nosso conceito de ordem pública, posto que também aqui houvesse esse privilégio, ainda que subsidiário. No entanto, à luz da ordem pública hoje vigente no País, poder-se-á entender que previsão dessa monta é ofensiva à igualdade que deve grassar entre os pais no que se refere a suas relações com a criança.

No terceiro nível, por fim, “em grau de natureza gravíssima, a ordem pública irá ao ponto de impedir a aceitação no foro de situações já consumadas e consagradas no

${ }^{300}$ DOLINGER. Contratos e obrigações..., cit., p. 544. 
exterior" ${ }^{\prime 301}$. Trata-se da recusa de reconhecer situações que configurem até mesmo eventual direito adquirido de uma das partes, justamente porque tal direito ofenda grandemente a filosofia político-jurídica do Estado, que este se recusa a reconhecê-lo. No que concerne ao objeto da tese, exemplificativa é a hipótese de se negar reconhecimento a uma decisão internacional que determine a alteração da guarda caso tal modificação tiver por esteio legislação de cariz religioso que, dada a sua natureza própria, seja o único fundamento para a concessão da medida, por exemplo. Em que pese a gravidade dessa ofensa, pode ser que modificações dos costumes ou da convivência sociais ocorridas no desenrolar dos acontecimentos forcem o Estado a mudar seu entendimento acerca da ordem pública, autorizando, por isso mesmo, o reconhecimento desses direitos até então afastados da esfera jurídica dos cidadãos. E isso porque, como lembra Bruno Miragem, "não se há de dizer a priori que o reconhecimento de determinadas relações pela ordem jurídica, em vez de outras, seja mais ou menos correto" ${ }^{302}$. Correção de opções jurídicas decorre da adequação de validade verificada nos moldes kelsenianos, ou seja, a partir de sua pertinência e conformidade com as disposições normativas hierarquicamente superiores e nesse sentido, pode-se perceber que o juízo atinente à aplicação do princípio da ordem pública não se perfaz com correção ou incorreção, muito embora possa a estes se amoldar, mormente quando a mutabilidade da caracterização do princípio da ordem pública, de dificílima configuração e de consolidação lenta e progressiva faz-se acompanhar de modificação legislativa (validamente elaborada) que servirá de indicativo dos valores sociais recentes de dada população. Nesse caso, a mutabilidade se consolida em um passo único, muito embora possa ser fruto de labor jurisprudencial ou doutrinário já antigos, enquanto arautos das modificações julgadas necessárias.

Na seara do direito de família, trata-se de realidade fortemente verificável inclusive por que se sabe que este é, seguramente, um dos ramos jurídicos que, pondo-se de lado a necessária cientificidade e sistematicidade, maiores influências sofre dos desígnios sociais. Por haver forte consenso no que se refere à ordem pública - o de que cabe ao juiz, ao analisar os casos concretos que tenha de julgar, verificar se é caso ou não para a aplicação do princípio e o conseqüente afastamento quer da vontade das partes, quer da lei estrangeira, quer do direito adquirido no exterior - pode-se dizer que as relações familiais

\footnotetext{
${ }^{301}$ DOLINGER. A evolução..., cit., p. 42.

302 MIRAGEM, Bruno. Conteúdo da ordem pública e os direitos humanos. Elementos para um direito internacional privado pós-moderno. In: MARQUES, Claudia Lima; ARAUJO, Nadia de. O novo direito internacional: estudos em homenagem a Erik Jayme. Rio de Janeiro: Renovar, p. 307-354, 2005, p. 315.
} 
plurilocalizadas são extremamente sensíveis à ordem pública dos Estados em que seus efeitos se devem produzir ${ }^{303}$.

\subsection{Atribuição da guarda}

Como ficou assentado no item 1.1, supra, a lei aplicável aos casos em que é necessário regular a guarda de crianças, determinando-se seu regime de atribuição e a pessoa que exercerá esse direito-dever, é a lei do domicílio do infante, por ser possível presumir que tal lei guarda maior contacto com a situação vivenciada.

Outro argumento, no entanto, pode ser apontado. Trata-se da dificuldade de se estabelecer, havendo divergência entre a lei pessoal do pai e a lei pessoal da mãe, aquela que seria aplicada nas hipóteses em que os pais vivessem em territórios distintos. Isso pode ocorrer no caso dos pais da criança estarem separados de fato, vivendo em países diferentes, ou na situação em que, durante o processo de separação, divórcio ou dissolução da união estável, um deles demonstre inequívoco intento de deixar o território do foro competente, modificando seu domicílio para outro Estado, tornando clara a distinção entre os domicílios dos membros da família. Também é possível configurar o problema nos casos em que, tendo sido regulada a atribuição da guarda, esteja-se a pleitear sua inversão, modificando-se as posições jurídicas entre genitor-guardião e não-guardião, o que, em razão da diversidade de domicílios existente entre os pais, acarretará necessária modificação do domicílio da criança.

A competência jurisdicional, nesses casos, tanto poderá ser do foro em que domiciliada a criança como do foro em que domiciliado o genitor não-guardião. Segundo o que dispõe o Código de Processo Civil em seu art. 88, sempre que o réu nessa ação esteja domiciliado no Brasil, ainda que de nacionalidade estrangeira (inc. I), sempre que a decisão judicial implicar a necessidade de cumprimento do dispositivo em território nacional (inc. II), ou sempre que o fato que ensejar o pedido de fixação ou modificação da guarda verificar-se em solo brasileiro (inc. III), a competência será do Judiciário nacional ${ }^{304}$. A previsão do

\footnotetext{
${ }^{303}$ Sem que tal forte consenso signifique, necessariamente, a formação de uma ordem pública mundial nem sequer em matéria tão sensível como a da poligamia. Nesse sentido, DOLINGER. Ordem pública mundial..., cit., p. 210.

${ }^{304}$ Podendo ser aplicado, ainda, o art. 100, I do CPC, nas hipóteses de atribuição da guarda no bojo das ações próprias à desunião dos pais, posto que, nesses casos, o foro competente será o do domicílio da mulher. Cf.
} 
inc. I trata dos casos em que o réu na ação que tenha por objeto a atribuição da guarda seja domiciliado no Brasil. Assim, se o genitor que se encontra na companhia de fato ou jurídica da criança for domiciliado em território nacional, terá o outro genitor a possibilidade de intentar ação aqui assistindo à aplicação da lei brasileira porquanto seja este o domicílio do infante. O conteúdo da decisão que prevê a atribuição da guarda que era exercida de fato pelo genitor réu ou a conversão do guardião determinado em provimento judicial anterior constitui medida que demanda atuação do Poder Público brasileiro, já que aqui se encontra a criança. Por essa razão, recomendável também que a ação seja aqui intentada ${ }^{305}$. Da mesma forma, nas hipóteses em que a causa de pedir se tenha produzido em território brasileiro, competente será o nosso juízo.

Há que se distinguir. A situação fática é uma só: um dos genitores, em companhia da prole, encontra-se domiciliado em um território nacional. O outro genitor ou mesmo um parente próximo que tenha direito de requerer a guarda das crianças é domiciliado em outro país. Mas se a situação fática é uma, sua conformação pode variar. Do que veio de ser consignado, percebe-se que o mais normal é que o genitor-guardião (fático, legal ou judicialmente estabelecido) tenha por domicílio algum ponto no território brasileiro, fixando a competência de nossa jurisdição com base nos incs. I ou II do art. 88 do CPC. Nesse caso, o Judiciário brasileiro aplicará nossas regras de conflito normativo no espaço e optará pela lei vigente no domicílio da criança para ser aplicada. Mas, nada obsta que o Judiciário alienígena também se considere competente, em situação idêntica. Nesse caso, sendo a ação proposta no exterior, a lei aplicável será escolhida segundo os desígnios do direito internacional privado daquele foro.

A segunda conformação para a mesma situação fática seria aquela relação em que o

DOLINGER. A criança no direito..., cit., p. 218. A competência fixada pelo art. 88 do CPC é concorrente, e não exclusiva, razão pela qual não poderá ser colocado o problema de eventual litispendência internacional, nesse caso não configurada. Cf. ARAUJO, Nadia de. Direito internacional privado: teoria e prática brasileira. 4. ed. Rio de Janeiro/São Paulo: Renovar, 2008, p. 223-250. Nos sistemas de common law, a fixação da competência internacional não costuma ser prevista abstratamente, mas, sim, ser decidida concretamente, pelo magistrado, na resolução do caso que lhe é apresentado. Se ele considerar que não deve exercer jurisdição, valer-se-á do princípio do forum non conveniens. A respeito, PANICO, Ruggiero Cafari. Diritto internazionale privato inglese e "jurisdiction" con particolare riguardo ai rapporti di famiglia. Padova: Cedam, 1979, p. 28 et seq; CHALAS, Christelle. L'exercice discrétionnaire de la competénce juridictionnelle en droit internacional privé. Aix-en-Provence: Presses Universitaires d'AixMarseille, t. I e II, 2000.

${ }^{305}$ Apesar de se referir a outro contexto, o fundamento para tal medida pode ser encontrado em DOLINGER. A criança no direito..., cit., p. 213. Trata-se, nesse caso, da impotência do juízo estrangeiro que não tenha a criança sob sua jurisdição para proceder ao recambiamento para seu Estado, além do custo e da demora para se fazer a citação do réu aqui, bem como para se conseguir o reconhecimento e execução da decisão estrangeira. Tudo isso está a indicar a preferência pela jurisdição em que a criança se encontre. 
genitor alijado da guarda de sua prole resida no Brasil, estando os demais envolvidos prole e guardião - domiciliados em território estrangeiro. Supondo-se que as regras de distribuição de competência vigentes no território estrangeiro guardem identidade com as regras brasileiras, de se convir que a ação a ser proposta pelo genitor domiciliado no Brasil deve ter melhor guarida no foro alienígena. No entanto, nada obsta que se configure a situação prevista no inc. III do mesmo artigo processual citado, quando então poderá configurar-se a competência do juízo nacional. Trata-se de circunstância verificada em território nacional que possa configurar a causa de pedir para a atribuição ou modificação da guarda pleiteada. Pode ocorrer nas situações em que o genitor domiciliado no Brasil tenha sido alijado da companhia diuturna de sua prole, pelo fato de carecer das melhores condições para seu exercício. Posteriormente, no entanto, adquire tais condições, por fato passado em nosso território, o que o transforma em detentor de condições mais favoráveis que as ostentadas pelo atual guardião fático ou jurídico. Nesse caso, nenhum argumento técnico obsta a que pleiteie seus direitos diante do juízo nacional, muito embora as questões práticas decorrentes da dificuldade de se estabelecer o relacionamento entre as jurisdições envolvidas, despidas de uma fastidiosa burocracia, estejam a indicar como melhor caminho a proposição da ação no foro estrangeiro, havendo sempre o risco da crescente adaptação da criança no território estranho ${ }^{306}$. Nesse caso, sendo proposta a ação em território brasileiro e estando a criança domiciliada no exterior, aplicável será a lei estrangeira. Dessa forma, o juiz nacional decidirá o sistema de guarda e a pessoa do guardião com base na lei alienígena.

Por fim, seja feita referência à situação em que um dos envolvidos declara, no transcorrer do processo, a intenção de mudar seu domicílio, fixando-o em país estrangeiro. Nesse caso, como a situação a ser analisada pelo juiz leva em consideração o momento atual, ou seja, o momento em que todos são domiciliados no território nacional, forçoso seria convir que o melhor esquadro para a hipótese estivesse no bojo do item precedente. No entanto, não se pode negligenciar que vontade desse jaez, declarada nos autos do processo de regulação da guarda de filhos menores, influenciará, de forma mais ou menos intensa, a convicção do magistrado que preside a transformação do litígio. Resta, então, discutir se tal fator poderá ser considerado pelo juiz no instante de decidir qual a lei aplicável ou se sua valoração correta seria a de, eventualmente, ser levado em consideração no momento de aplicação do direito material. O problema se põe, por óbvio, nas hipóteses

${ }^{306}$ DOLINGER. A criança no direito..., cit., p. 212. 
em que o juiz tenciona outorgar a guarda da prole justamente ao genitor que declara a intenção de alterar seu domicílio, carreando consigo a prole, que se fixará no exterior. Parece que tal situação não terá força suficiente para alterar a lei a ser aplicada, mas certamente será considerada pelo juiz.

Quid juris nesses casos? Manter a convicção de que aquele genitor apresenta as melhores condições para o exercício da guarda ou, ao contrário, defender suposto direito da criança de ser criada em sua pátria, envolta em sua própria cultura, ou no local onde passará a se domiciliar por decisão do virtual guardião? Creio que escolher a segunda alternativa seria tolher da criança e do genitor que ostenta as melhores condições para o exercício da guarda seu direito de ir, vir e ficar, pois pode bem representar ingerência nas decisões do particular, posto não se deva negligenciar a hipótese de o genitor frear sua decisão para ter consigo a companhia da prole. Ademais, deve-se zelar para que as decisões judiciais não transpirem "nacionalismo equivocado", contrário "ao espírito universalista que deve imperar nas decisões jusprivatista-internacionalistas", como frisa Jacob Dolinger ${ }^{307}$.

$\mathrm{O}$ argumento cultural, em que pese ser fator importante para a tomada da decisão mais condizente aos interesses da criança, deve ser sopesado, mormente quando há identidade cultural entre os países envolvidos e quando a alteração do domicílio possa representar vetor de crescimento intelectual imediato e profissional mediato. Mesmo que se dê aplicação ao posicionamento doutrinário defendido por Erik Jayme, no sentido de que o "pós-moderno" direito internacional privado deve dar maior atenção aos sentimentos interiores do indivíduo, seus interesses e valores pessoais ${ }^{308}$, deve-se atentar para a situação particular da criança enquanto ser em formação, sopesando-se as possíveis vantagens e desvantagens advindas da alteração domiciliar que se fará, frise-se, em companhia do virtual guardião, possivelmente seu pai ou sua mãe, ou seja, daquela pessoa que, pela análise dos fatos, o juiz cogitou ser o que deteria as melhores condições para o exercício da guarda. Note-se, ademais, que os mencionados aspectos pessoais guardam maior pertinência com o mérito da decisão, com a decisão material em si, e não com a decisão típica do direito internacional privado que é a determinação da lei aplicável para a regulação transformadora dos fatos. Assim, deixe-se assente que a possível modificação do domicílio é fator incidente importante, mas não exclusivo para a decisão de mérito.

${ }^{307}$ DOLINGER. A criança no direito..., cit., p. 222.

${ }^{308}$ JAYME. Identité culturelle..., cit., p. 9-268. 


\subsection{Direito de visita}

No que concerne à lei aplicável para regular o exercício do direito de visitas, necessário que se dê relevo ao fato de que o escopo principal do instituto é o de garantir a convivência dos membros da família. Nesse sentido, como já repisado, além de direito de quem é visitado e dever para aquele que visita, constitui-se também em direito dos que visitam, apresentando características de dever de quem é visitado. Indisfarçável, assim, o caráter dúplice do instituto, que busca privilegiar uns e outros. Em verdade, que busca privilegiar a unidade do núcleo familiar - que se assemelha a uma família monoparental - que se quer preservar.

Nesse sentido, já que o instituto não apresenta apenas característica protetiva dirigida às crianças, mas a todos os membros da família, inclusive da família alargada, restaria despido de sentido defender a aplicação da lei do domicílio da criança, tão-somente com o argumento de se tratar da defesa de seu melhor interesse. Certamente que se reconhece à criança a situação de ser humano em formação, vivenciando estágio de seu desenvolvimento em que os referenciais paterno e materno são de extrema importância. Mas, nesse caso, parece que sobrelevar essa característica é desmerecer o direito que o genitor não-guardião e os restantes membros da família alargada têm de conviver com os mais jovens ${ }^{309}$.

Trata-se, no entanto, de conseqüência direta da atribuição da guarda. Assim, como esta

\footnotetext{
${ }^{309}$ Nesse sentido, não parece acertada a decisão lançada pelo STJ no Recurso Especial 761.202/PR, Relator o Ministro Castro Filho, julgado em 28 de junho de 2006, cuja ementa está assim redigida:

"I - A exigência da ida da criança ao exterior, anualmente, durante as férias escolares de meio e fim de ano, pelo período de quatro meses, torna-se inviável de ser cumprida, por sua dificuldade e dispendiosidade dos deslocamentos, principalmente levando-se em conta a tenra idade da criança, que, na época, contava com dois anos e meio e, atualmente, está com seis anos.

Ademais, é de se ter presente a informação de que o genitor ingressou com uma ação pleiteando a guarda da criança na justiça espanhola, o que significa a possibilidade de não retornar ao Brasil, se permitida a sua saída, não se tratando, portanto, de mera suposição, mas, sim, de risco iminente e comprovado. Assim, é mais conveniente que o pai, professor com doutorado, experiência internacional em ministrar cursos e palestras pelo mundo todo, a visite no território brasileiro, a qualquer tempo, dada a facilidade em exercer o direito de visitas no Brasil.

II - Na regulamentação de visitas, deverão ser preservados os interesses do menor, que sobrelevam a qualquer direito dos pais, juridicamente tutelado".

Se é certo que os interesses da criança deverão ser preservados e prevalecer sobre os interesses dos genitores, não se compreende em que medida pode o judiciário brasileiro presumir que a ida da criança para a Espanha, para lá conviver com seu pai, configure a possibilidade - quase certeza - de seu não retorno. Ainda mais porque tanto o Brasil quanto a Espanha são partes na Convenção da Haia de 1980 sobre seqüestro.
} 
foi deferida com base na lei do domicílio da criança, parece ser conveniente que se estabeleça a competência da mesma lei nas hipóteses de famílias que se separam e passam a viver em Estados soberanos diversos. Justifica-se tal posicionamento na necessidade de se evitar confrontos entre os genitores em decorrência de conflito de preceitos materiais existentes nos sistemas jurídicos dos Estados em que domiciliados, os quais poderiam regular diversamente o direito de acesso à criança. Ademais, submeter a regulamentação do exercício do direito de visitas à lei pessoal do genitor-guardião ou do não-guardião poderia acarretar o desencadeamento de hipótese que hoje parece remota ${ }^{310}$, mas que pode efetivamente se configurar, qual seja, a de o sistema de direito material vigente no Estado em que domiciliado o não-guardião desconhecer o instituto do direito de visita ou não reconhecer este direito quando conformado por disposição de lei estrangeira incompatível por qualquer razão com a ordem pública ali vigente ${ }^{311}$.

Além disso, garantir-se que a mesma lei que regula a guarda seja aplicada para regular o direito de visita parece proporcionar mecanismos mais seguros de acompanhamento efetivo do exercício desse direito-dever, distribuindo-se da melhor maneira possível o tempo que a criança passará com cada tronco familiar ${ }^{312}$.

Mas a situação se complicará sempre que genitor e prole estiverem excessivamente distantes, porquanto nesses casos as visitas tornar-se-ão esporádicas, muito embora concentradas, podendo mesmo ocorrer uma abstenção no gozo desse direito e no exercício do dever correlato durante anos. Acresçam-se as dificuldades econômicas normalmente vividas pelos indivíduos para se ter uma dimensão da gravidade do problema. Além disso,

${ }^{310}$ Conforme demonstra o art. $9^{\circ}, 4$, da Convenção sobre os direitos das crianças. Assim: WEINBERG. Inés M. Protección integral de la familia. In: WEINBERG. Inés M. (Dir.). Convención sobre los Derechos del Niño. Buenos Aires: Rubinzal-Culzoni, p. 174-179, 2002, p. 179.

${ }^{311}$ Hipótese esta que parecia perfeitamente possível no passado, segundo se depreende do seguinte excerto da lavra de PONTES DE MIRANDA. La conception..., cit., p. 635: "On doit reconnaître (...) le droit de voir et de visiter l'enfant accordé à la mère, bien que leur loi n'ait pas créé ce droit".

${ }^{312}$ A afirmação do texto, no entanto, deve ser vista com ressalvas. Muitas vezes, os obstáculos que foram levantados para o efetivo exercício desse direito persistem na prática, por renitência jurisprudencial, não obstante as disposições internacionais de direitos humanos a respeito. Cf. interessante exemplo do que se passava entre casais formados por franceses e argelinos em MEBROUKINE, Ali. La convention algérofrançaise du 21 juin 1988 relative aux enfants de couples mixtes séparés. Le point de vue d'un Algérien. Revue Critique de Droit International Privé, Paris, v. 80, n. 1, p. 1-39, 1991, p. 9 et seq. Informa o autor que "avant l'adoption de la convention du 21 juin 1988, l'exercice du droit de visite par le parent non gardien obéissant aux deux règles suivantes: a) Le droit de visite faisait l'objet d'une limitation spatiale en France. b) Ce droit ne s'accompaignt pas obligatoirement d'une reconnaissance, au profit du parent non gardien, de la possibilité pour lui d'emmener l'enfant dans le pays de sa nouvelle résidence". A convenção tratou de regrar a questão de forma mais condizente com os avanços sociais, garantindo que o direito de visita pudesse ser exercido tanto externa como internamente, ou seja, tanto no país do domicílio do nãoguardião como no domicílio da criança (p. 18). 
como a ausência se torna prolongada, tanto pode ocorrer a não-adaptação entre nãoguardião e prole como pode dar-se a conseqüência inversa: o largo lapso temporal experimentado desde a última visita pode ser pretexto para que nasça entre genitor e filho o desejo de não mais se separarem. Essa realidade, extremamente grave, determinará o nãocumprimento correto do direito de visitas, cujo ilícito, de natureza civil, aperfeiçoar-se-á com a não-devolução da criança no prazo assinalado, acarretando violação das disposições da lei aplicável para regular a questão. Entretanto, sua não-devolução ao guardião e o conseqüente afastamento da criança de seu habitat representam situação de difícil desfecho, com tendência para se agravar sempre que se fizer atuar os mecanismos burocráticos para determinar o retorno da criança. É sabido que a tendência natural de quem se encontra em situação como essa é continuar a se evadir, o que retarda o deslinde da questão, pois, muitas vezes, perde-se a pista relativa ao paradeiro da criança ${ }^{313}$.

Bem por isso, cedo se percebeu que os métodos tradicionais de resolução do problema (verificação do ilícito, pedido de seu reconhecimento à jurisdição que regulava o direito de visita, comprovação de violação da determinação normativa, prolação de sentença, pedido de reconhecimento da sentença estrangeira ao foro do domicílio do não-guardião ou outro qualquer em que o mesmo se encontrasse com a criança e execução da decisão) eram lentos, custosos e despidos de necessária efetividade. Então, para procurar remediar a questão, arquitetando mecanismos mais eficazes para a resolução do problema do exercício abusivo do direito de visitas transfronteiriço, a sociedade internacional houve por bem buscar uma regulamentação conjunta da questão que deu origem à Convenção da Haia sobre os aspectos civis do seqüestro (subtração) internacional de crianças, de 1980, objeto de análise no capítulo IV.

\subsection{Alimentos}

Os elementos de conexão geralmente indicados para reger a escolha da lei aplicável à matéria relacionada aos alimentos são normalmente, como se viu no item 1.3, supra, a lei

\footnotetext{
313 "The intention behind the private international law is not to take children permanently away from their abductors but to restore a situation in which children may have as regular an acess as possible bearing in mind that the parents live in different states. For these reasons neither treaty focusses on the penal punishment of the abductor. This is not only because the paucity of international criminal law but also because international child abduction is a difficult situation which criminalisation may aggravate and drive the abductor and abducted child further into hiding" (BUEREN. The international law..., cit., p. 91).
} 
pessoal do devedor ou a do credor, com certa preferência doutrinária e jurisprudencial por essa última, dada a situação de necessidade que atinge a criança alimentanda, razão pela qual há quem defenda, com mais razão, a aplicação da lei mais favorável ao alimentando, seja a lei pessoal do devedor ou do credor.

Acredita-se que o critério da lei mais favorável seja efetivamente o melhor. Com efeito, o escopo social a que o instituto se dirige é prover o sustento necessário - bem assim as condições de manutenção e desenvolvimento cultural - do jovem alimentando. Presumirse-ia, então, que a lei pessoal do credor pudesse ser a que melhor regulasse a matéria, mas não se pode olvidar que o caráter materialista da discussão recomenda que se opte pela aplicação da lei que seja, efetiva e não presumidamente, a que mais benefícios traz para o credor. $\mathrm{O}$ argumento lançado aqui poderá causar interpretação apressada e imprudente no sentido de ser sempre preferível garantir o maior valor ao alimentando. Não é essa, todavia, a posição que se está a defender. A defesa recai sobre a lei que garanta as melhores condições de sobrevivência e inclusão do credor em seu mundo social (veja-se o capítulo I). Trata-se, portanto, de comparar as leis potencialmente aplicáveis naquilo que respeita ao conteúdo da dívida alimentícia, a fim de saber que necessidades, efetivamente, estão abarcadas no quantum a ser fixado. O valor devido, agora sim, levará em consideração o binômio que opõe a necessidade do credor e as possibilidades efetivas do devedor. A despeito de, à primeira vista, a questão parecer argumentativa e retórica, não é esse o caso. Há legislações que entendem devidos apenas os alimentos estritamente necessários à sobrevivência do credor, dando preferência absoluta ao fator necessidade (estrita), ao passo que outros ordenamentos entendem possível e recomendável que a verba alimentícia abarque não só o valor mencionado, mas que cubra, também, os gastos que a criança terá para se inserir no meio social em que nasceu e com o qual está acostumada entendendo-se amplamente o fator necessidade -, mas desde que o devedor mantenha, obviamente, condições financeiras para sua própria sobrevivência condigna e para o suprimento daquelas necessidades de sua prole, já que, muitas vezes, os processos de separação das famílias acabam por implicar uma perda significativa do padrão socioeconômico.

Em um ponto específico, entretanto, a razão parece estar entre aqueles que advogam a aplicação da lei do devedor, como é o caso de Luís Cezar Ramos Pereira. Trata-se da alegação segundo a qual tal solução facilitaria o reconhecimento da condenação estrangeira 
(proferida no foro do domicílio do credor ou, ainda, se cabível, em outros foros competentes) no Estado do devedor, com posterior execução ${ }^{314}$, já que respeitada a lei do domicílio do ora executado. A mesma solução pode-se mostrar dificultada caso se assente na adoção da lei mais benéfica, mormente se o juízo de delibação versar o tema da ordem pública do Estado requerido. A depender da concepção socioeconômica do Estado, poderse-á negar executoriedade à decisão que se tenha lavrado com base na lei do credor, então considerada a mais benéfica ao mesmo, principalmente se a condenação se mostrar muito mais ampla do que aquela que se teria atingido na hipótese de aplicação da lei do domicílio do devedor.

Segundo informa Jacob Dolinger, quando vigorava entre nós a regra da nacionalidade como definidora da lei pessoal, seguia-se essa regra geral para buscar a aplicação da lei da nacionalidade do pai (devedor) a fim de definir o débito alimentício. No entanto, sempre que a lei nacional do devedor de alimentos (lei estrangeira) o eximia integralmente dessa responsabilidade, o sistema brasileiro fazia incidir o princípio da ordem pública, forçando à aplicação da lei nacional, justamente por se mostrar mais benéfica ao alimentando ${ }^{315}$.

Com a alteração, em 1942, do critério definidor da lei pessoal, que deixa de ser a nacionalidade e passa a ser o domicílio, e com a extensão do domicílio do pai ao fillho por expressa disposição legal (art. $7^{\circ}, \S 7^{\circ}$, da LICC/1942), "teria se fixado a competência da lei do alimentante" (devedor). Ainda segundo o autor, "esta solução não foi aceita, pois já se firmara tradição de que a lei do alimentado [credor] e/ou a lex fori teriam que ser consultadas para garantir a concessão dos alimentos"316.

Não se percebe, todavia, a alteração de critérios, nem que se tenha fixado, apenas em 1942, a competência da lei do alimentante. Com efeito, se a lei aplicável antes de 1942 era a estrangeira e se a sua aplicação era, muitas vezes, obstada pela ordem pública nacional "sempre que estes [os alimentos] não estivessem garantidos na lei nacional do pai”, como afirma o autor, onde a alteração do critério? Parece, da narração feita pelo autor, que sempre se aplicou no país a lei do alimentante (devedor), porém com a possibilidade de aplicação da lex fori e/ou da lei do credor quando esta favorecesse o alimentando, que, no mais das vezes domiciliado no Brasil, veria coincidir os conceitos de lex fori e lei pessoal,

\footnotetext{
${ }^{314}$ PEREIRA. Prestação de alimentos..., cit., p. 35.

315 No mesmo sentido FERNÁNDEZ ROZAS, José Carlos. Las obligaciones alimenticias en el derecho internacional privado español. Revista Española de Derecho Internacional, Madrid, v. 37, n. 1, p. 67-108, 1985, p. 98, ao afirmar que seria hipótese de se afastar a lei estrangeira com recurso à ordem pública.

${ }^{316}$ DOLINGER. A criança no direito..., cit., p. 386.
} 
por colmatagem com a noção domiciliar.

\subsection{Administração dos bens de filhos menores}

Coerentemente com o posicionamento que se veio de firmar no item 1.4, supra, entende-se que a lei aplicável para regular a administração e o usufruto dos bens dos filhos menores é a lei pessoal vigente para estes e não a lei da situação dos bens, como sói acontecer nos países de tradição insular.

O problema se colocará, aqui, relativamente aos bens situados no Brasil, que deverão ser administrados e usufruídos da forma e pelas pessoas indicadas na lei vigente no Estado em que domiciliada a criança proprietária. Vale dizer, tendo havido a separação internacional da família da criança, determinará a forma de administração dos bens a ela pertencentes, bem como a pessoa ou as pessoas que se incumbirão dessa empreitada, a lei do Estado em que a criança tiver fixado seu domicílio.

Dessa feita, tendo a criança deixado o país em companhia do genitor-guardião para fixar o seu domicílio no exterior, a lei brasileira terá perdido a proeminência para regular a questão, não obstante os bens usufruídos e/ou administrados encontrarem-se situados no Brasil (rei sitae). Competente será a lei do local em que atualmente domiciliada a criança, que determinará se a administração do patrimônio do incapaz caberá ao guardião, ao nãoguardião ou a terceira pessoa, bem como se o administrador será beneficiado com usufruto temporário de tais bens, além das formalidades necessárias para sua eventual alienação ou para a imposição de gravames reais.

Por outro lado, se a criança permanece domiciliada em território nacional, serão chamados a administrar e usufruir os bens situados no Brasil ambos os genitores, em cooperação, mesmo que - como é a hipótese geral do presente tópico - um deles esteja domiciliado no exterior e apresente dificuldades de ordem prática para participar da tarefa que a lei pessoal de seu filho lhe impõe, o que geralmente ocorrerá em razão da distância imposta pela separação transfronteiriça dos membros da família. Saber se o não-guardião pode solicitar dispensa de tal incumbência nessa situação ou se poderá instituir mandatário que se desincumba de tal obrigação dependerá, portanto, das disposições materiais da própria lei brasileira. 


\subsection{Exercício do poder familiar na desunião das famílias}

A lei aplicável, nessa hipótese em que os pais da criança decidem viver em Estados soberanos distintos, será a lei do domicílio do jovem que se visa proteger por meio do instituto.

Quer isso significar que, se a criança permanece em território nacional, terá sobre si o império do poder familiar nos exatos moldes traçados pela legislação brasileira, que regulará sua titularidade, a forma de seu exercício, bem como as hipóteses de perda e suspensão desse poder. Por outro lado, se a criança modifica seu domicílio, indo residir no exterior em companhia de um dos genitores, detentor de sua guarda, aplicável será a lei pessoal da criança, preenchidos o sentido e o alcance da expressão à luz do direito internacional privado do foro. É que este direito tanto pode considerar como lei pessoal o domicílio, caso em que a lex fori será também a lex causae, como pode considerar o elemento nacionalidade para fixar o conceito de lei pessoal, conjectura em que a lei aplicável será a da nacionalidade da criança.

\section{ALTERAÇÃO POSTERIOR DAS SITUAÇÕES FÁTICAS}

\subsection{Separação transfronteiriça dos membros da família que permanecia no mesmo território}

Uma vez definidos a guarda; o regime de visitação; o valor e a forma de pagamento da pensão alimentícia; a quem incumbiria, e de que modo, a administração dos bens das crianças, bem como a forma de exercício do poder familiar com base na lei brasileira, como lei pessoal da criança, ou com base na lei que fosse mais favorável a ela no que concerne aos alimentos fixados - situação a que se chegava pela verificação de permanecerem todos os membros da família no mesmo território -, pode bem se dar a hipótese de um ou alguns deles modificarem seu domicílio, indo residir no exterior. A mesma situação é possível verificar na hipótese em que, ausente qualquer elemento estrangeiro na situação fática, fosse até então a questão submetida exclusivamente aos 
desígnios da lei local por se tratar de um caso tipicamente interno, referenciado exclusivamente ao sistema jurídico brasileiro, que se mostrava o único, àquele momento anterior, com aptidão para regular a situação.

Em qualquer dessas duas hipóteses, percebe-se que a situação fática poderá desencadear mecanismos distintos de atuação da normativa de direito internacional privado, conforme se trate de hipótese em que o guardião pretende alterar seu domicílio, levando consigo a criança para o exterior, ou de hipótese em que apenas o não-guardião pretende ausentar-se do País, fixando seu domicílio em país estrangeiro.

Nessa segunda hipótese, parece não haver razão maior para se proceder a qualquer alteração na regulação da guarda, do poder familiar e do direito de administrar e usufruir os bens existentes no patrimônio da criança, que permanecerão regidos pela lei brasileira, já que este é o domicílio da criança. No entanto, no que tange aos alimentos, passar-se-á a contar com um elemento de conexão novo - a lei do domicílio do devedor - chamado a atuar, fazendo incidir a necessária comparação entre as legislações a fim de se buscar o sistema mais favorável para a criança. Também no que respeita ao direito de visitas, poderá ele necessitar de nova regulamentação, que será traçada, entretanto, ainda com base na lei brasileira, lei que regulamenta a guarda e que deve ser estendida a suas conseqüências mais diretas: as visitas entre criança e membros do grupo familiar afastados de sua convivência diuturna. A alteração de mérito, assim, justifica-se pela eventual necessidade de fixação de calendário de visitação mais condizente com as necessidades da criança.

No entanto, na situação em que o guardião pleiteia o direito de mudar seu domicílio para residir no exterior, fazendo-o em companhia da prole, alteradas estarão as remissões feitas pelos elementos de conexão da grande maioria dos aspectos aqui analisados, cabendo, entretanto, indagar se a alteração futura, aquela que se vai produzir, mas que ainda não se produziu, poderia ser levada em consideração para que o magistrado brasileiro alterasse a guarda. A pergunta se coloca porquanto se deve ter em mente que a alteração do domicílio da prole e do guardião provocará, possivelmente, a deslocação da competência internacional e eventual incompetência do juízo brasileiro ${ }^{317}$, pois, muito embora se trate de competência concorrente, como já se afirmou, há quem entenda que as hipóteses que

\footnotetext{
${ }^{317}$ Isso porque não se trata nem de dependência da competência internacional relativamente ao direito aplicável, nem do direito aplicável relativamente à competência internacional. A respeito, PINHEIRO, Luís de Lima. Direito internacional privado, v. 3. Coimbra: Almedina, 2002, p. 27-37, que afirma: "a competência internacional é um pressuposto de aplicabilidade do direito de conflitos pelos órgãos públicos" (p. 37).
} 
não se enquadram nos incisos do art. 88 afastariam a competência brasileira (Botelho de Mesquita), incluir-se-iam nas hipóteses de competência negativa da jurisdição brasileira (Antenor Madruga) ou, ante o silêncio da lei, não afastariam a competência do juízo nacional (Marcelo de Nardi) ${ }^{318}$. Assim, alterado o domicílio da criança e alterada, eventualmente, a competência internacional, o juiz brasileiro, caso entendesse que não poderia prolatar decisão alguma a respeito da guarda de filhos, poderia antecipar-se para antever o direito estrangeiro que será aplicado e, assim, modificar quer a guarda, quer o regime de visitas, quer a administração dos bens do infante? Não parece haver razão para tal iniciativa afoita. Obviamente, o juiz poderá considerar a situação mesma da deslocação internacional da criança e ponderar a respeito da conveniência de sua retirada do território nacional, podendo, se entender conveniente, alterar a guarda da criança, à luz da lei brasileira, ainda aplicável à questão. Mas não poderá jamais adiantar-se para fazer incidir uma lei que será aplicável apenas e tão-somente se o elemento estrangeiro for efetivamente alterado, conectando a questão a outra ordem jurídica, distinta da brasileira.

No que concerne ao exercício conjunto do poder familiar determinado pela lei brasileira enquanto lei do domicílio da criança pode-se pôr a questão de saber se a modificação do domicílio do infante para um outro país, que não admita o exercício conjunto da autoridade parental expressa no poder familiar, persistirá ou não. A questão, formulada pelo Secretário-Geral-adjunto da Conferência da Haia de Direito Internacional Privado, o irlandês William Duncan, em outro contexto, está assim vazada:

"A child is born to parents habitually resident in State X. According to the law of State $\mathrm{X}$ the parents by operation of law are vested with joint parental responsibility. Some years later, the family moves to State Y. Under the domestic law of State Y parents do not automatically enjoy joint responsibility. (This may be because they are unmarried; or perhaps, for traditional or religious reasons, responsibility vests in only one married parent.) Does the change in habitual residence necessarily affect the position as regards parental responsibility?"319

Muito embora no exemplo do autor os pais permaneçam unidos nos desígnios que lhes são comuns, notadamente na criação e educação de seus filhos, na companhia constante de

\footnotetext{
${ }^{318}$ Assim, ARAUJO. Direito..., cit., p. 226-228, quando cita o posicionamento de José Ignácio Botelho de Mesquita, Antenor Madruga e Marcelo de Nardi.

319 DUNCAN, William. Children's rights, cultural diversity and private international law. In: Children's Rights and Traditional Values. Aldershot/Brookfield (USA)/Singapore/Sydney: Ashgate-Dartmouth, 2002 (fornecido pela Secretaria Permanente da Conferência da Haia de Direito Internacional Privado, p. 12).
} 
ambos, pode-se bem adaptar a questão para fazê-la enquadrar no problema central deste item. Ao que parece, nesse caso, um dos genitores perderia a responsabilidade parental pela modificação do domicílio da criança sob guarda. A solução é certamente injusta, posto que a decisão unilateral do guardião imputará ao não-guardião a perda da autoridade parental, sem que este tenha cometido qualquer ato atentatório à dignidade e à integridade da criança. Obviamente, essa decisão não produzirá efeitos em nosso território, mas poderá ser o estopim para que se negue autorização para que o não-guardião visite sua prole, por exemplo. Levando às últimas conseqüências, então, o não-guardião, mesmo que procure resguardar seus direitos diretamente no foro do domicílio de seu filho - já que seja este o foro mais próximo à realidade do infante - terá sua pretensão negada a menos que o elemento de conexão vigente nesse Estado seja a nacionalidade da criança e seja ela brasileira. Mas mesmo essa hipótese redentora dependerá de não se invocar a ordem pública do Estado em questão, já que o autor do exemplo invocou como causa possível, por exemplo, questões religiosas.

William Duncan escreve por ocasião da aprovação da "Convention concernant la compétence, la loi applicable, la reconnaissance, l'exécution et la coopération en matière de responsabilité parentale et de mesures de protection des enfants”. Essa convenção será o objeto principal da atenção do capítulo IV, posto que se esteja, nesta tese, na busca de elementos que corroborem a ratificação de uma série de convenções internacionais sobre o assunto, ainda não ratificadas pelo Estado brasileiro. Como se verá, a convenção garante, nessa hipótese em especial, a manutenção do genitor não-guardião no exercício de seu status quo ante, se a residência habitual da criança se tiver fixado em país que seja, também ele, parte na referida convenção.

\subsection{Reunião dos membros da família em território nacional}

Já na hipótese de reunião ${ }^{320}$ de todos os membros da família da criança em território

\footnotetext{
${ }^{320}$ O tema merece outro viés de análise no âmbito comunitário europeu. Com efeito, tendo-se em conta as disposições internacionais relativas ao direito à convivência familiar, os Estados europeus dispõem de regras jurídicas que reconhecem aos indivíduos regularmente assentados em dado território, o direito de terem consigo seus familiares. Obviamente, o direito se efetiva com particularidades quando se trata de cidadãos comunitários ou não comunitários. A respeito: ARENAS GARCÍA, Rafael. Problemas derivados de la reagrupación familiar. Anuário Español de Derecho Internacional Privado, Madrid, n. 5, p. 269-307, 2005.
} 
nacional, após período em que se encontravam domiciliados em dois ou mais Estados distintos, assistindo à regulação de suas relações cotidianas pela lei estrangeira, ao retornarem todos para o território nacional dever-se-á indagar, primeiramente, se existe na relação fática algum elemento estrangeiro outro que não o domicílio de parte dos membros da família quando se encontravam no exterior. Em caso de resposta negativa, inclusive no que concerne à existência de membros da família alargada no exterior, o caso perderá a característica que demandava a atuação do direito internacional privado, devendo submeter-se, a partir de então, à legislação material brasileira, que se aplicará própria e diretamente.

Já no caso de haver algum elemento estrangeiro na relação, mesmo depois da reunião da família em território brasileiro, persistirá a necessidade de se indagar sobre a lei aplicável a suas relações, que serão regidas em sua maioria, como se afirmou, pela lei brasileira, enquanto lei do domicílio da criança, ou pela lei mais favorável ao credor dos alimentos. Nesse caso, como os elementos pertinentes relacionam-se ao ordenamento brasileiro, será esta a aplicável. 


\title{
REGULAÇÃO DO TEMA PELA SOCIEDADE INTERNACIONAL
}

\author{
SUMÁRIO: 1. A Convenção da Haia concernente à competência, lei aplicável, \\ reconhecimento, execução e cooperação em matéria de responsabilidade parental e medidas \\ de proteção da criança, de 1996 - 2. A Convenção da Haia sobre os aspectos civis do \\ seqüestro (subtração) internacional de crianças, de 1980 - 3. A Convenção interamericana \\ sobre restituição internacional de menores, de 1989 - 4. A Convenção da Haia sobre a lei \\ aplicável às obrigações alimentares, de 1973 - 5. A Convenção da Haia sobre o \\ reconhecimento e a execução de decisões relativas a obrigações alimentares, de 1973 - 6. A \\ Convenção da Haia sobre cobrança de alimentos destinados às crianças e a outros membros \\ da família.
}

\section{A CONVENÇÃO DA HAIA CONCERNENTE À COMPETÊNCIA, LEI APLICÁ VEL, RECONHECIMENTO, EXECUÇÃO E COOPERAÇÃO EM MATÉRIA DE RESPONSABILIDADE PARENTAL E MEDIDAS DE PROTEÇÃO DA CRIANÇA, DE 1996}

Esta convenção, aprovada no seio da Conferência da Haia de Direito Internacional Privado $^{321}$, encontra precedentes na história das próprias Conferências. Sua aprovação teve como um de seus objetivos, expressamente declarados em seu preâmbulo, o de revisar as disposições da Convention du 5 octobre 1961 concernant la compétence des autorités et la loi applicable en matière de protection des mineurs ${ }^{322}$ que, por sua vez, havia sido

\footnotetext{
321 Trata-se de organização internacional que persegue a unificação progressiva das regras de direito internacional privado. Nascida das constantes convocações de conferências internacionais por parte do governo do Reino dos Países Baixos, sob a influência de Tobias Michael Carel Asser, que conseguiu por em prática o sonho que fora acalentado originalmente por Pasquale Stanislao Mancini, entretanto morto, a Conferência institucionalizou-se em 1951. Originalmente freqüentada por países europeus, tem hoje como membros países de todos os continentes, filiados a todas as grandes famílias jurídicas, dentre os quais o Brasil que, após curto período como membro, na década de 1970, denunciou o Estatuto e voltou a ser membro efetivo em 2001, tendo, no entanto, participado de reuniões como convidado nesse interregno. Cf.: RODAS; MONACO. A Conferência da Haia..., cit., p. 99-102, 121, 129-133, 145-152 e 159-167.

${ }^{322}$ Todas as convenções da Conferência da Haia de Direito Internacional Privado podem ser consultadas em sua página na rede mundial de computadores (www.hcch.net).
} 
aprovada como conseqüência da percepção de que a Convention du 12 juin 1902 pour régler la tutelle des mineurs era dotada de mecanismos que haviam se tornado ineficazes para a persecução de seu objetivo principal ${ }^{323}$.

A Convenção sobre a competência e a lei aplicável em matéria de proteção de menores, de 1961, entrou em vigor internacional em 4 de fevereiro de 1969, dez anos depois de proclamada a Declaração universal dos direitos da criança e pode, por isso, ser apontada como uma das primeiras tentativas da comunidade internacional no sentido de tornar instrumentais os direitos então declarados, por meio de sua positivação internacional. Atualmente, vigora ainda para treze Estados europeus (Alemanha, Áustria, Espanha, França, Holanda, Itália, Letônia, Lituânia, Luxemburgo, Polônia, Portugal, Suíça e Turquia $^{324}$ ) e para Macau, dos quais Letônia (por ratificação) e Lituânia (por adesão) são partes na convenção de 1996.

A convenção de 1961 atribui competência genérica em favor das autoridades judiciárias e administrativas de um determinado Estado contratante para que este tome as medidas consideradas necessárias para garantir proteção aos direitos pessoais e patrimoniais da criança $^{325}$ sempre que sua residência habitual esteja fixada naquele Estado (art. $1^{\text {o }}$ ),

\footnotetext{
${ }^{323}$ A respeito das dificuldades havidas na aplicação da convenção de 1902 sobre tutela, inclusive com referência ao caso Boll, julgado pela Corte Internacional de Justiça (Affaire relative à la Convention de 1902 pour régler la tutelle des mineur, arrêt du 28 novembre 1958), e que desembocaram na aprovação da convenção de 1961, veja-se, dentre muitos outros: PÉREZ VERA, Elisa. El menor en los convenios de la Conferencia de la Haya de Derecho Internacional Privado. Revista Española de Derecho Internacional, Madrid, v. 45, n. 1, p. 101-114, 1993, p. 104-105. Entre nós, com ricos detalhes: DOLINGER. A criança no direito..., cit., p. 192-198. O referido caso opôs Suécia e Holanda relativamente a medidas de proteção tomadas pelos judiciários de ambos os países, em caráter definitivo, com referência à mesma criança. Com efeito, no que diz respeito a essa temática, e como se verá, no texto, adiante, é possível que se estabeleça conflito entre uma medida provisória tomada em um Estado e uma medida definitiva tomada em outro Estado. No entanto, como salientam VERWILGHEN; HOUTTE. Conflits d'autorites..., cit., p. 407, nesses casos, normalmente a medida definitiva destina-se a substituir a medida provisória. Mas também é possível que o conflito se instaure entre duas medidas com vocação definitiva. Foi o que ocorreu no caso Boll em que cada Estado determinou medidas diversas de proteção à criança: assistência educativa (Suécia) e atribuição do poder familiar ao pai da menina e, posteriormente, a tutela da mesma a uma tutora (Holanda). Segundo os últimos autores citados, o tipo de conflito inscrito no caso Boll foi a origem das tensões entre jurisdições de Estados diferentes.

${ }^{324}$ Polônia e Turquia não participaram das negociações, tendo aderido à convenção. Conforme dispõe o art. 21, 2, do texto convencional, os Estados signatários têm a faculdade de declarar se aceitam que a convenção os vinculem aos Estados aderentes, o que se faz por meio de declaração dirigida ao depositário. Cf. BONOMI, Andrea. La convenzione dell'Aja de 1961 sulla protezione dei minori: un riesame dopo la ratifica italiana e l'avvio dei lavori di revisione. Rivista di Diritto Internazionale Privato e Processuale, Padova, v. 31, n. 3, p. 607-656, 1995, p. 608, nota 3. As conclusões do autor podem ser estendidas à Letônia, Lituânia e Macau. Curiosamente, o autor inclui dentre os Estados contratantes a Eslovênia. Todavia, esta informação não se coaduna com aquela disponível em http://hcch.evision.nl/upload/statmtrx_f.pdf (último acesso em 23.09.2008).

${ }^{325}$ A convenção considera como criança o ser humano que ostente esta condição tanto na legislação do Estado de sua nacionalidade como no Estado de sua residência habitual. Trata-se de critério cumulativo,
} 
estabelecendo-se como lei aplicável para reger tais medidas urgentes de proteção o ordenamento jurídico do foro, a lex fori (art. $2^{\circ}$ ). A previsão convencional relativa à competência dá vazão ao chamado princípio da eficiência, por se considerar que as autoridades desse Estado parte são as que ostentam melhores condições e melhores informações para intervir imediatamente a fim de proteger a criança. Por outro lado, a previsão a respeito da lei aplicável se atém à verificação do princípio da coincidência forum-ius $^{326}$. Lembra Rui Manuel Moura Ramos que, muitas vezes, as medidas a se tomar no âmbito interno do Estado serão da alçada das autoridades administrativas. Assim, como a estas não é exigido o conhecimento jurídico, ser-lhes-ia muito difícil aplicar qualquer norma estrangeira, dada a tecnicidade presente em tal procedimento. Daí a conveniência do recurso ao princípio da coincidência forum-ius ${ }^{327}$. Além disso, e com Batiffol, o autor lembra que o recurso a tal princípio permitiu afastar a discussão, de resto de difícil enfrentamento à época, acerca de qual dos elementos de conexão escolher para a regência dos aspectos pessoais e familiares: se a lei nacional ou a domiciliar ${ }^{328}$. No entanto, o assunto aparece camuflado na convenção.

Segundo suas disposições, as medidas tomadas com base nos artigos $1^{\circ}$ e $2^{\circ}$ subsistirão apenas até que outro Estado que também seja competente, porém por título diverso (nacionalidade da criança, v.g.), tome as medidas exigidas pela situação. Da mesma forma, prevê o art. $9^{\circ}$ que a competência se desloca, em casos extremos e urgentes, para o Estado em que a criança se encontrar. Em ambas as hipóteses, o Estado que determinar uma medida de proteção deve comunicá-la ao Estado da nacionalidade da criança ou ao Estado de sua residência habitual, conforme o caso $^{329}$. Segundo Peter Nygh, há certa preferência pelo critério da nacionalidade para a fixação da competência quando se trata de tomar medidas definitivas relativamente à proteção das crianças, conforme determinação contida no art. $4^{\mathrm{o}}$ da convenção ${ }^{330}$, bastando, para tanto, a demonstração de seu interesse em

portanto, e que acaba privilegiando a determinação legislativa material que estabelece a idade mais baixa. Cf. BAUDOUIN, Jean-Marie. La protection du mineur étranger par le juge des enfants. Revue Critique de Droit International Privé, Paris, v. 83, n. 3, p. 483-503, 1994, p. 488.

${ }^{326}$ MOURA RAMOS. Rui Manuel Gens de. La protección de los menores en el âmbito internacional - las nuevas normas convencionales de La Haya aplicables a la protección de menores en supuestos de conexión múltiple. Estatuto personal y multiculturalidad de la familia. Madrid: Colex, p. 67-84, 2000, p. 70.

${ }^{327}$ MOURA RAMOS. Da lei aplicável..., cit., p. 164.

${ }^{328}$ MOURA RAMOS. Da lei aplicável..., cit., p. 163-164.

${ }^{329}$ BAUDOUIN. La protection..., cit., p. 490-491.

330 A preferência pela nacionalidade tornou esta convenção não aceitável por parte dos países afetos à common law. Assim: NYGH, Peter E. The New Hague Convention on Child Protection. Australian Journal of Family Law. v. 11, p. 5-10, 1997, p. 5. 
decidir sobre a questão conflituosa, tudo a fim de garantir maior permanência e unidade da lei aplicável, se comparada à lei da residência habitual, de mais fácil modificação ${ }^{331}$. Como ressalta Paul Lagarde "la competénce prioritaire reconnue par l'article 4 aux autorités nationales de l'enfant n'est qu'une survivance historique qui n'a plus sa place dans une convention moderne" ${ }^{, 332}$, e isso porque a maior proximidade parece ser aquela que se estabelece com o Estado da residência habitual da criança.

Outro problema que efetivamente se põe é aquele relativo às crianças com dupla ou plúrima nacionalidade, quando então, vários Estados, que consideram a criança como sua nacional, poderão requerer o reconhecimento de sua competência ${ }^{333}$, o que forçou muitos Estados europeus propensos a reconhecer casos de plúrima nacionalidade a firmarem uma série de convenções bilaterais ${ }^{334}$. O problema se justifica pela igualdade entre homem e mulher no que concerne à manutenção e transmissão de sua nacionalidade nos países afetos ao sistema do ius sanguinis. Com efeito, se no passado a mulher adquiria, por via do casamento, a nacionalidade de seu marido e se a nacionalidade se transmitia à prole em razão da paternidade, a criança ostentava a nacionalidade comum de seus pais. De forma correlata, mesmo nos países em que era reconhecido à mulher o direito de manter sua nacionalidade originária, era-lhe tolhido o direito de transmiti-la à prole, razão pela qual a criança era nacional de um único Estado: o Estado de seu pai. Essa realidade persistia em 1961, quando da assinatura da convenção, mas foi logo substituída pelos avanços sociais. Soma-se a isso o fato da Conferência da Haia contar dentre seus membros, atualmente, Estados que transmitem a nacionalidade ius soli, senão exclusivamente (v.g., países da América Latina), ao menos subsidiariamente (v.g. França e Portugal) ${ }^{335}$. A verificação do fenômeno da dupla nacionalidade, então, pode representar a adoção de medidas concomitantes e incoerentes entre si, por parte de cada um desses Estados, tal qual ocorrera, à luz da convenção de 1902, no caso Boll. A solução para tal conflito aparente de jurisdições, então, baseia-se na busca de critérios subsidiários que possam determinar a nacionalidade prevalecente, quase sempre com recurso à primazia da nacionalidade do

\footnotetext{
${ }^{331}$ HERRANZ BALLESTEROS, Mónica. El interés del menor en los convenios de la Conferencia de La Haya de Derecho Internacional Privado. Valladolid: Lex Nova, 2004, p. 123.

${ }^{332}$ LAGARDE, Paul. La protection du mineur double-national talon d'achille de la Convention de La Haye du 5 octobre 1961. L'unificazione del diritto internazionale privato e processuale - Studi in memoria di Mario Giuliano. Padova: Cedam, p. 529-542, 1989, p. 540.

333 MONTANARI, Michela. Giurisdizione e riconoscimento delle decisioni sulla protezione del minore bipolide tra convenzione dell'Aja del 1961 e diritto comune. Rivista di Diritto Internazionale Privato e Processuale, Padova, v. 38, n. 1, p. 99-118, 2002, em especial p. 105 et seq.

${ }_{334}$ MOURA RAMOS. La protección..., cit., p. 71.

${ }^{335}$ LAGARDE. La protection..., cit., p. 531.
} 
foro, o que é, em verdade, tornar irrelevante a dupla nacionalidade ${ }^{336}$.

De forma coerente, a convenção de 1961 prevê que toda medida de proteção determinada pelo Estado da nacionalidade da criança em decorrência da aplicação de sua lei interna será imediatamente reconhecida em todos os Estados contratantes, sem dispor, no entanto, relativamente à executoriedade de tais decisões, que restam, portanto, afetas aos mecanismos de execução disciplinados pelo direito interno dos Estados requeridos, o que dificulta o funcionamento prático dos mecanismos estatuídos pela convenção ${ }^{337}$. Daí porque Tito Ballarino tenha classificado tais mecanismos de cooperação entre as autoridades dos Estados contratantes como "poco efficaci" 338 .

Todo esse mecanismo criado pela convenção de 1961 pressupõe um intrincado sistema de comunicação entre os Estados parte que, todavia, prescindem, em sua estrutura organizacional, de entidades com a competência das atuais autoridades centrais ${ }^{339}$, previstas em várias convenções da Conferência da Haia para facilitar a comunicação internacional relativamente à aplicabilidade das convenções que as prevêem ${ }^{340}$.

Tendo como principal objetivo o de obter o compromisso dos Estados quanto à repartição de competências, a convenção de 1961 trouxe inúmeros problemas que, na prática, impossibilitaram uma efetiva coordenação entre as autoridades do Estado de residência habitual e do Estado da nacionalidade da criança ${ }^{341}$. Além disso, a ausência de regras explícitas e facilitadoras a respeito do reconhecimento e da execução de tais decisões sobre medidas de proteção, como já se salientou, acabou por tornar incompleta a convenção nas hipóteses em que se fazia necessária a produção dos efeitos da sentença em Estado outro que não o da nacionalidade da criança, como por exemplo, o Estado da situação dos bens. Naqueles casos, principalmente, não obstante ter-se aplicado, com

${ }^{336}$ Com a citação de inúmeros casos e seus critérios de resolução: LAGARDE. La protection..., cit., p. 532539.

${ }^{337}$ BAUDOUIN. La protection..., cit., p. 491.

${ }^{338}$ BALLARINO, Tito. Diritto internazionale privato. 2. ed. Padova: Cedam, 1996, p. 489.

${ }^{339}$ Cf. BAUDOUIN. La protection..., cit., p. 492, nota 16, ao informar a competência interna francesa para receber tais comunicações. Aliás, a dificuldade de se estabelecer esta autoridade foi um dos fatores responsáveis pelo tardio depósito do instrumento de ratificação italiano, realizado após o início das negociações, em sede de comissão especial, para a substituição da convenção de 1961 . A respeito da peculiaridade italiana, BONOMI. La convenzione..., cit., p. 609-610.

${ }^{340}$ Veja-se, a respeito: BORRÁS RODRÍGUEZ, Alegría. El papel de la "autoridad central": los Convenios de La Haya y España. Revista Española de Derecho Internacional, Madrid, v. 45, n. 1, p. 63-80, 1993.

${ }^{341}$ BORRÁS, Alegría; PÉREZ VERA, Elisa. Conferencia de la Haya de Derecho Internacional Privado: primera comisión especial para la modificación del Convenio sobre protección de menores (26 de mayo a 3 de junio de 1994). Revista Española de Derecho Internacional, Madrid, v. 46, n. 2, p. 916-919, 1994; DE BOER, Ted. The Hague Conference and Dutch choice of law: some criticism and a suggestion. Netherlands International Law Review, The Hague, v. 40, n. 1, p. 1-14, 1993, p. 6. 
grande probabilidade, a lei da nacionalidade da criança, impossibilitava-se o reconhecimento automático da decisão nesse último Estado, tornando moroso o seu reconhecimento e morosa a produção de seus efeitos.

No que concerne ao âmbito material de aplicação da convenção, no entanto, um grande passo foi dado relativamente a sua antecessora, a convenção de 1902, posto que ampliado o conceito de medidas de proteção, abandonou-se a regulação da lei aplicável tão-somente para reger a tutela, passando-se a regular a competência e a lei aplicável às medidas de proteção em geral, o que parece refletir certo avanço na consideração da condição da criança enquanto sujeito de direitos, na esteira, aliás, da Declaração universal dos direitos da criança, como já se salientou. Nesse sentido, essa convenção permite a repartição de competência e prevê a lei aplicável no que concerne à regulação do exercício do poder familiar quando os pais se separam, a forma de atribuição da guarda etc. muito embora fosse possível aos Estados partes reservar a aplicação da convenção nas hipóteses de separação dos genitores ${ }^{342}$.

Em que pese o fato de vigorar entre vários e importantes países europeus, não se vai dar maior atenção a esta convenção, pois, como já ressaltado, a mesma temática por ela regulada mereceu a atenção dos Estados membros por ocasião das negociações que levaram à adoção da Convention concernant la compétence, la loi applicable, la reconnaissance, l'exécution et la coopération en matière de responsabilité parentale et de mesures de protection des enfants ${ }^{343}$, de $1996^{344}$. Esta convenção entrou em vigor internacional em $1^{\circ}$ de janeiro de 2002 e conta hoje com a participação dos seguintes

\footnotetext{
${ }^{342}$ VERWILGHEN; HOUTTE. Conflits d'autorites..., cit., p. 412.

${ }^{343}$ O Bureau Permanente da Conferência da Haia de Direito Internacional Privado havia proposto três possíveis denominações para a convenção em tela, todas mais sintéticas que o nome afinal adotado. Dentre elas, a sugestão que parecia agradar mais era "Convention sur la protection internationale des enfants", que acabou sendo adotada, na prática, por muitos autores que escreveram sobre o tema. O título sugerido, no entanto, dizia pouco sobre o conteúdo do acordo ao mesmo tempo em que demonstrava aptidão para se referir a toda sorte de proteção, podendo remeter o intérprete mais apressado, por exemplo, à idéia de se tratar de uma convenção sobre direitos humanos. Daí a proposta holandesa no sentido de se batizar o tratado de "Convention réglant le droit international privé en matière de proteccion des enfants". Prevaleceu, entretanto, a proposta analítica elaborada conjuntamente por uma série de delegações. Cf. PICONE, Paolo. La nuova convenzione dell'Aja sulla protezione dei minori. Rivista di Diritto Internazionale Privato e Processuale, Padova, v. 32, n. 4, p. 705-748, 1996, p. 76, nota 1.

${ }^{344}$ Quanto aos trabalhos tendentes à revisão da convenção de 1961: BORRÁS, Alegría. Conferencia de la Haya de Derecho Internacional Privado: segunda comisión especial para la revisión del Convenio de la Haya de 1961 sobre protección de menores (La Haya, 6-17 de febrero de 1995). Revista Española de Derecho Internacional, Madrid, v. 47, n. 1, p. 314-317, 1995; BORRÁS, Alegría. Conferencia de la Haya de Derecho Internacional Privado: tercera reunión de la comisión especial sobre la protección de los menores y de los incapaces mayores (La Haya, 11-22 de septiembre de 1995). Revista Española de Derecho Internacional, Madrid, v. 47, n. 2, p. 493-495, 1995.
} 
Estados membros da Conferência: Albânia, Austrália, Bulgária, Equador, Eslováquia, Eslovênia, Estônia, Hungria, Letônia, Lituânia, Marrocos, Mônaco, República Tcheca, Ucrânia, além da adesão da Armênia. A convenção encontra-se, no entanto, assinada pelos seguintes países membros da Organização Internacional: Alemanha, Áustria, Bélgica, Chipre, Dinamarca, Espanha, Finlândia, França, Grécia, Holanda, Irlanda, Itália, Luxemburgo, Polônia, Portugal, Romênia, Reino Unido, Suécia e Suíça ${ }^{345}$. Percebe-se, assim, que se ratificadas todas as assinaturas apostas à convenção, apenas Turquia e Macau continuarão, no futuro, afetas às disposições da convenção de 1961. Além do mais, a prática da conferência tem demonstrado que nessas hipóteses, acaba ocorrendo a denúncia por parte dos Estados que se encontram apegados aos textos mais antigos. Foi o que aconteceu, por exemplo, com a convenção sobre adoção internacional firmada na década de 60, e hoje totalmente substituída pela convenção de 1993.

Os desenvolvimentos sociais levam a que as convenções sobre lei aplicável a aspectos do direito de família se tornem, em boa medida, supérfluas. Tal fato atingiu em cheio a convenção de 1961 e havia consenso no que concerne à necessidade de sua substituição paulatina. Agregado a esse fator, recordou-se a inexistência prática de uma convenção que regulasse as medidas de proteção dirigidas a adultos incapazes, então ainda regidas pela convenção de $1905^{346}$. Todos esses fatores levaram a que se discutisse no seio da Conferência a possibilidade de alargamento da convenção a fim de que ela abarcasse o reconhecimento e a execução de decisões, bem como que se procurasse incluir nessa nova convenção medidas de proteção dirigidas aos maiores incapazes. Durante as negociações, no entanto, foi proposta a separação dos objetos por sujeito de proteção, que dariam origem a duas distintas convenções: uma sobre a proteção das crianças e outra sobre a proteção dos adultos incapazes ${ }^{347}$.

\footnotetext{
${ }^{345} \mathrm{Cf}$. http://hcch.e-vision.nl/upload/statmtrx_f.pdf Último acesso em 23.09.2008.

346 "Le nombre des personnes âgées de plus de 60 ans devrait être de 600 millions en 2001 et doubler avant 2025. Celui des personnes âgées de plus de 80 ans, actuellemente de quelque 50 millions, passerait à 137 millions en 2025. La démence sénile, particulièrement la maladie d'Alzheimer, croît avec l'âge. Des études épidémiologiques fon apparaître que le taux de démence, de 3\% entre 65 et 74 ans, passe à $18 \%$ entre 75 et 84 ans, pour atteindre $47 \%$ au-delà de 85 ans. Actuellement, $20 \%$ des personnes âgées de plus de 80 ans seraient démentes. (...). Le problème de la protection des majeurs s'est internationalisé du fait à la fais de l'accroissement des mouvements de populations et de la répartition de plus en plus fréquente des biens d'un même patrimoine sur le territoire de plusiers États." LAGARDE, Paul. La convention de la Haye du 13 janvier 2000 sur la protection internationale des adultes. Revue Critique de Droit International Privé, Paris, v. 89, n. 2 , p. $159-179,2000$, p. 161-162.

${ }^{347}$ Tanto assim que as duas convenções tiveram o mesmo relator, o Professor Paul Lagarde. Cf. LAGARDE, Paul. La nouvelle convention de la Haye sur la protection des mineurs. Revue Critique de Droit International Privé, Paris, v. 86, n. 2, p. 217-237, 1997, p. 218, nota 2; LAGARDE, Paul. La convention de
} 
O objeto dessa convençãoconsiste em determinar a competência dos Estados no que concerne à tomada de medidas tendentes à proteção da pessoa das crianças e à proteção de seus bens, além de se designar a lei que deverá ser aplicada por tais Estados considerados competentes para o estabelecimento das medidas cabíveis. Também é estabelecida a lei aplicável à regulação da autoridade parental, cuja extensão é trazida pela convenção, como se verá.

Da mesma forma, a convenção estabelece a obrigação e assegura que todos os Estados contratantes reconheçam e executem as decisões havidas em outro Estado parte, além de criar mecanismos de cooperação considerados necessários para o bom funcionamento e persecução dos objetivos da convenção. Isso porque as normas de cooperação entre autoridades nacionais se apresentam como ponte apta a permitir o bom funcionamento das regras relativas aos demais setores regulados pela convenção.

A convenção de 1996 define autoridade parental como a regulação dos direitos, deveres e obrigações que incumbem aos pais, aos tutores ou a quaisquer outros representantes legais das crianças, no exercício da proteção de sua pessoa e dos bens a elas pertencentes. Na esteira da Convenção sobre os direitos da criança, de 1989, a convenção de 1996 considera criança todo ser humano que conte até dezoito anos de idade.

A convenção optou por estabelecer uma lista não exaustiva ${ }^{348}$, mas meramente exemplificativa do que pode ser considerado "medidas de proteção", para, em seguida, excluir de seu campo de aplicação algumas medidas que, em que pese poderem ter algum caráter protetivo, constituem objeto de regulação por outras convenções da $\mathrm{Haia}^{349}$, ou a respeito dos quais não se tenha atingido consenso quando se buscava estabelecer o campo de aplicação da convenção, optando-se pela exclusão de tais medidas em alguns casos ${ }^{350}$.

Assim, são medidas de proteção ao abrigo da convenção: a atribuição, o exercício, a suspensão ou a destituição da responsabilidade parental, bem como sua delegação temporária ou definitiva. A atribuição da guarda de filhos, bem como a regulação do

la Haye du 13 janvier 2000 sur la protection internationale des adultes. Revue Critique de Droit International Privé, Paris, v. 89, n. 2, p. 159-179, 2000, p. 160, nota 3.

${ }^{348}$ BUCHER, Andreas. L'enfant en droit international privé. Genève/Bâle/Munich: Helbing \& Lichtenhahn, 2003, p. 178, aceitando o caráter não exaustivo do rol, afirma no entanto que "il est très difficile de trouver une mesure qui ne pourrait être ragée dans aucune des rubriques".

349 Assim, também, ITERSON, Dorothea van. The New Hague Convention on the Protection of Children: A View from the Netherlands. Uniform Law Review/Revue de Droit Uniforme, Paris, n. 3, p. 474-487, 1997, p. 476.

${ }^{350}$ LAGARDE. La nouvelle convention..., cit., p. 221. 
direito-dever de visitas, o que inclui, no âmbito da guarda, o direito de fixar o domicílio ${ }^{351}$ e a residência ${ }^{352}$ da criança e, no âmbito do direito-dever de visitas, a possibilidade de remover a criança, temporariamente, para um local diverso daquele em que reside habitualmente. A tutela, a curatela ${ }^{353}$ e medidas análogas são também incluídas no âmbito da convenção, bem como a possibilidade de sua transferência a uma família acolhedora ou a um estabelecimento oficial, além de se prever a instituição da kafala muçulmana, que se incluiria no meio do caminho entre a guarda de fato de uma criança e a adoção simples ${ }^{354}$. Da mesma forma, inclui-se no âmbito da convenção a designação de pessoas ou instituições que serão responsáveis pela criança, como é o caso de uma babá ou de um colégio interno, devendo-se obedecer, nesses casos, a lei indicada pela convenção.

Também está incluída a obrigação estatal de se fiscalizar os atos relativos ao exercício do poder familiar, ou à autoridade parental - para falar nos termos da convenção exigindo-se certa atuação que vise, por exemplo, suspender o poder familiar mal exercido. Por fim, deve-se fazer referência à obrigação de se administrar os bens dos infantes ${ }^{355}$. Não há, portanto, incompatibilidades de fundo entre esta convenção e a Convenção de 1989 sobre os direitos da criança ${ }^{356}$, podendo-se, por isso, adiantar que a convenção de 1996 encontra-se harmoniosa relativamente à legislação material brasileira vigente.

Quanto aos temas que se encontram excluídos do âmbito de aplicação da convenção, deve-se fazer referência ao seu caráter peremptório ${ }^{357}$. Assim, a convenção não se aplica a

\footnotetext{
351 "Domicile can present distortions, particularly when the domicile of a child is dependent on that of an absent parent" NYGH, Peter. The Hague convention on the protection of children. Netherlands International Law Review, The Hague, v. 45, n. 1, p. 1-28, 1998, p. 12-13.

${ }^{352}$ MOURA RAMOS. La protección..., cit., p. 72.

${ }^{353}$ No Brasil a curatela é medida de proteção destinada a adultos incapazes e, portanto, estaria ao abrigo material da convenção de 2000 , sobre a proteção internacional dos adultos.

354 "La Kafala è un istituto del diritto islamico, non assimilabile all'adozione e inidoneo a produrre legami di filiazione, per cui un fanciullo bisognevole di protezione può essere (dal giudice tutelare o eccezionalmente dagli stessi genitori) affidato da una istituzione pubblica o privata, o ad una famiglia mussulmana, che si prenderà cura della sua persona e dei suoi beni”. PICONE. La nuova convenzione..., cit., p. 711, nota 19. Também: BECK-PECCOZ, Roberta Aluffi. Le leggi del diritto di famiglia negli stati arabi del nord-Africa. Torino: Fondazione Giovanni Agnelli, 1997.

${ }^{355}$ Muito embora, nesse caso, a convenção admita, por meio do art. 55, a aposição de reserva quanto a competência de outros Estados, estabelecendo sua competência exclusiva em razão do elemento de conexão locus rei sitae internamente adotado pelo Estado.

356 "Era stata presentata una proposta tendente a precisare quali principi della convenzione delle Nazioni Unite sui diritti del fanciullo (del 20 novembre 1989) andassero presi particolarmente in considerazione, ma la proposta non ha ricevuto il consenso della larga maggioranza delle delegazioni”. A proposta fora apresentada por Organizações não-governamentais participantes da sessão diplomática na qualidade de convidadas. Cf. PICONE. La nuova convenzione..., cit., p. 708-709 e nota 11.

${ }^{357}$ LAGARDE. La nouvelle convention..., cit., p. 221.
} 
diversos casos que a própria aplicação prática da convenção de 1961 tratou de descartar ${ }^{358}$ : estabelecimento ou contestação de paternidade, adoção, salvo suas conseqüências, porquanto esse ato jurídico estabeleça verdadeira relação paterno-filial, em tudo assemelhada à filiação biológica. Também não se aplica à regulação do nome e prenome da criança, a sua emancipação, às obrigações alimentares, ao trust e à sucessão ${ }^{359}$, à seguridade social, às políticas públicas de caráter geral ou homogêneo ${ }^{360}$ relativos à educação e à saúde, às medidas de caráter social tendentes à reintegração social de jovens que tenham cometido algum ato infracional ou análogo, bem como as decisões em matéria de asilo $^{361}$ e imigração ${ }^{362}$.

De maneira geral, a convenção atribui competência para processar e decidir a respeito das medidas de proteção às autoridades judiciais ou administrativas do Estado contratante em que a criança tenha sua residência habitual, por as considerar as autoridades melhor situadas para a decisão ${ }^{363}$. Como ocorre com as demais Convenções firmadas na Conferência da Haia, esta não define o que seja residência habitual. Trata-se de política deliberada da organização, como deixa claro Peter Nygh:

\begin{abstract}
"Although the concept of habitual residence is known to some legal systems and is use by them for private international law purposes, the Hague Conference concept must be seen as an autonomous non-technical concept. It indicates the centre of gravity of the child's life and activities at the relevant time. (...). The habitual residence of the child need not coincide with that of the parent or parents. Obviously the child who lives with the mother will have its centre of life's activities at the same place as the mother. But, if she sends the child to live with others, their habitual residence will diverge whether or not the person with whom the child lives has formal rights of control over the child"364.
\end{abstract}

\footnotetext{
${ }^{358}$ BUCHER. L'enfant..., cit., p. 178.

${ }^{359}$ O que, segundo a visão de NYGH. The New Hague..., cit., p. 6, tornou a convenção pouco interessante no que concerne aos bens das crianças.

${ }^{360}$ Prefere-se homogêneo, porquanto tais políticas dirijam-se a todos os seres humanos sob jurisdição do Estado, independentemente de qualquer traço distintivo, característico da heterogeneidade de seus destinatários. Cf. MONACO. A proteção..., cit., introdução e capítulos 3 a 5.

${ }^{361}$ As medidas de proteção relativamente às crianças refugiadas podem ser tomadas com base na convenção segundo determina o art. $6^{\circ}$ do texto. A respeito: ITERSON. The New Hague..., cit., p. 478.

362 "Se percibe la intención del legislador de circunscribirse al ámbito de las relaciones de derecho privado, dejando fuera del sistema creado las grandes instituciones autónomas del derecho de la persona, incluso si la normativa referente a ellas puede abarcar cuestiones que afectan a la protección de los menores" (MOURA RAMOS. La protección..., cit., p. 72).

${ }^{363}$ HERRANZ BALLESTEROS. El interés del menor..., cit., p. 124.

${ }^{364}$ NYGH. The Hague convention..., cit., p. 12-13
} 
A alteração da residência habitual implica, normalmente, e salvo as hipóteses de modificação ilícita da mesma, a alteração da competência que, entretanto, permanece relativamente às autoridades originalmente competentes nas situações de ilicitude ${ }^{365}$ (subtração ou não-retorno), exceto se houver concordância - ainda que ficta - dos responsáveis pela criança com a alteração da residência. Tal concordância se determina pela contagem do prazo de um ano a partir da ciência efetiva ou presumida (do momento em que o guardião soube ou devia ter sabido) do atual paradeiro da criança por parte de seus responsáveis. Ou seja, sua inatividade implicará, nesses casos, na alteração da residência habitual da criança para fins de determinação da competência internacional para o estabelecimento de medidas de proteção ${ }^{366}$. Deve-se, no entanto, cuidar para uma verificação rigorosa de tais situações. Nesses casos, Andreas Bucher lembra que a propositura de ação de busca e apreensão pelo guardião, assim como qualquer outra medida por ele aventada que demonstre claramente sua não concordância com a subtração da criança, será apta a conservar a competência no local da residência habitual originária da criança. Lembra, no entanto, que as autoridades do local onde a criança se encontrar serão sempre competentes para adotar quaisquer medidas que considerem necessárias e urgentes para a proteção dos infantes ali localizados ${ }^{367}$.

Em qualquer hipótese, a autoridade competente do Estado da residência habitual da criança pode renunciar a sua competência em favor de outros Estados contratantes, desde que se configure algum dos casos previstos no art. 8 da convenção, como é o caso da transferência de competência para o Estado da nacionalidade da criança, o Estado onde estão situados seus bens, ou, ainda, o caso de transferência da competência para outros Estados, competentes para julgar temas correlatos àquele que está em tela. Com efeito, nas hipóteses de situações ligadas exclusivamente a um ordenamento jurídico, costuma viger o sistema de cumulação de competências em que o juiz competente para decidir acerca do divórcio, da separação ou de qualquer outra forma de dissolução da vida em comum dos membros de um casal acabam assumindo a competência para decidir acerca das questões correlatas a estas. Tal sistema, que em princípio não vigora em casos afetos ao direito internacional privado ${ }^{368}$ em razão da aplicabilidade dos princípios da proximidade e da

\footnotetext{
365 PFUND. The Developing..., cit., p. 673.

${ }^{366}$ MOURA RAMOS. La protección..., cit., p. 74.

${ }^{367}$ BUCHER. L'enfant..., cit., p. 181.

${ }^{368}$ Veja-se, por exemplo, o art. $8^{\circ}$ da Convenção interamericana sobre normas gerais de direito internacional privado, que dá faculdade ao juiz para aplicar o direito internacional privado da lex fori, não se sujeitando,
} 
proteção da parte mais fraca da relação (forçando o estabelecimento de competências preferentes que dispersam a análise dos temas correlatos em foros estrangeiros diversos) ${ }^{369}$, pode, no entanto, ceder, segundo as disposições da convenção, forçando o julgamento de questões prévias, preliminares ou incidentes à atribuição da guarda no foro destas primeiras. Trata-se, especificamente, da hipótese de dissolução, por qualquer modo e razão, da união havida entre os pais da criança (art. 10) ${ }^{370}$. Essa hipótese de transferência da competência, no entanto, não estava prevista no projeto originalmente apresentado para discussão, elaborado pelo Bureau Permanente da Conferência. Isso porque alguns Estados afirmavam inexistir qualquer liame entre a criança e tal foro. Se esta afirmação é verdadeira, não se deve esquecer que a jurisdição do divórcio pode ser recomendável por razões táticas ou financeiras, conforme lembra Eric Clive ${ }^{371}$. Por fim, como regra flexível e ampla, admite-se a transferência da competência para o Estado com o qual a criança demonstrar possuir vínculos mais estreitos. No entanto, esta forma de migração da

obrigatoriamente, ao direito internacional privado da lex causae. Cf. DOLINGER, Jacob. Convenção interamericana sobre normas gerais de direito internacional privado. Revista da Faculdade de Direito da Universidade do Estado do Rio de Janeiro, Rio de Janeiro, n.3, p.19-46, 1995, p. 42-43.

369 CALVO CARAVACA, Alfonso-Luís; CARRASCOSA GONZÁLEZ, Javier. Derecho internacional privado. v. 2. 5. ed. Granada: Comares, 2004, p. 354-355.

${ }^{370}$ BUCHER. L'enfant..., cit., p. 183 lembra que a regra do art. 10 da convenção de 1996 pressupõe que a autoridade judiciária ou administrativa competente para decidir sobre a dissolução da união havida entre os pais da criança seja, também, competente para adotar medidas de proteção relativamente às crianças envolvidas, o que pode simplesmente não ocorrer.

${ }^{371}$ CLIVE, Eric. The New Hague Convention on Children. Greens Family Law Bulletin, p. 3-5, Jan 1997, p. 3. A modificação de posicionamento se deu, no seio das negociações, por pressões exercidas pelos países membros da União Européia, que estavam a negociar, por aquele período, uma convenção sobre competência judiciária e execução de decisões em matéria matrimonial, comumente chamada de Convention Bruxelles II. Assim: PICONE. La nuova convenzione..., cit., p. 719. Sobre a convenção Bruxelas II: BORRÁS, Alegría. Competencia judicial, reconoscimiento y ejecución de decisiones en materia matrimonial: el reglamento 1.347/2000, de 29 de mayo (Bruselas II). Revista Jurídica de Catalunya, Barcelona. v. 102. n. 2. p. 361-386. 2003; ESPINOSA CALABUIG, Rosario. La responsabilidad parental y el nuevo reglamento de "Bruselas II, bis": entre el interés del menor y la cooperación judicial interestatal. Rivista di Diritto Internazionale Privato e Processuale, Padova, v. 39, n. 3-4, p. 735-782, 2003; DE BOER, Th. M. Jurisdiction and enforcement in international family law: a labyrinth of European and international legislation. Netherlands International Law Review, The Hague, v. 49, n. 3, p. 307-351, 2002; M'ELEAVY, Peter. The Brussels II regulation: how the european community has moved into family law. International and Comparative Law Quarterly, London, v. 51, n. 4, p. 883-908, 2002.; $\mathrm{M}^{\mathrm{c} C L E A N, ~ D a v i d . ~ T h e ~ H a g u e ~ c h i l d ~ a b d u c t i o n ~ c o n v e n t i o n ~-~ t h e ~ c o m m o n ~ l a w ~ r e s p o n s e . ~ N e t h e r l a n d s ~}$ International Law Review, The Hague, v. 40, n. 1, p. 67-78, 1993; WATT, Horatia Muir; ANCEL, Bertrand. La désunion européenne: le réglement dit 'Bruxelles II'. Revue Critique de Droit International Privé, Paris, v. 90, n. 3, p. 403-457, 2001. Sobre a transferência de competência dos Estados membros da União Européia em matéria de direito internacional privado, que levou, inclusive, à revisão do Estatuto da Conferência da Haia de Direito Internacional Privado: KOTUBY Jr, Charles T. External competence of the european community in the Hague Conference of Private International Law: community harmonization and worldwide unification. Netherlands International Law Review, The Hague, v. 48, n. 1, p. 1-30, 2001. Seja como for, a competência do foro do divórcio é limitada à atribuição da guarda, cessando em outras oportunidades que exijam a revisão do provimento inicial. Cf.: CLIVE. The New Hague..., cit., p. 3. Ademais, exige-se que ambos os genitores concordem com a competência deste foro e que este se mostre adequado aos interesses da criança. Cf. BUCHER. L'enfant..., cit., p. 184. 
competência para decidir a respeito de uma medida de proteção da criança deve obedecer a um procedimento de comunicação entre as autoridades centrais designadas pelos Estados para esse fim. Mantém-se, nesse ponto, a previsão da convenção de 1961, mas se obriga os Estados parte a indicarem qual o órgão interno de sua estrutura orgânica que se desincumbirá de tais tarefas ${ }^{372}$.

Dessa forma, apenas nas hipóteses em que a autoridade do segundo Estado (diferente do Estado em que a criança tem sua residência habitual) aceitar a competência para o processamento do feito $^{373}$ é que se admitirá que o órgão competente do primeiro Estado (residência habitual) decline da competência que lhe é reconhecida. Trata-se, bem se vê, de critério de atribuição de competência subsidiária ${ }^{374}$, só se admitindo que o Estado da residência habitual decline de sua competência se houver manifestação expressa de outro Estado que a convenção considera adequada para transformar o litígio, dizendo que aceita processar o feito, por se considerar este foro o conveniente para tanto (forum conveniens). A razão é clara: garantir que o melhor interesse da criança (aqui, interesse na resolução da lide) possa ser garantido, o que não ocorreria se a convenção tivesse propugnado pela adoção pura e simples da doutrina do forum non conveniens, já que, nessa hipótese, caso o juízo do local da residência habitual não se considerasse competente, o mesmo ocorrendo com outros foros previstos na convenção, a lide restaria insolúvel. Bem por isso, conforme determinado na convenção, apenas se houver a aceitação da competência pelo juízo considerado subsidiário, poderá a autoridade competente originária declinar de sua competência. O juízo de conveniência levado a cabo pelo Estado cuja jurisdição parece ser a mais adequada deve levar em consideração também o melhor interesse da criança. Já não mais em perspectiva procedimental (interesse na resolução da lide), mas em perspectiva material $^{375}$. Vale dizer: os Estados parte da convenção garantiram aplicação ao princípio do melhor interesse da criança ao criar mecanismos que impossibilitam a denegação de justiça, o que ocorreria se tivessem admitido que o tratado denotasse tão-só a doutrina do forum non conveniens. Cabe, no entanto, ao Estado que se julgar o mais adequado para proceder à transformação do litígio, voltar a considerar o melhor interesse da criança, agora em perspectiva material, por julgar que sua jurisdição é a mais conveniente para

\footnotetext{
${ }^{372}$ Relação em: http://www.hcch.net

${ }^{373}$ A convenção deixa claro, em seu art. $8^{\circ}$, que se trata de uma faculdade garantida ao segundo Estado e, não, de um dever a ele imposto.

${ }^{374}$ Nesse sentido: NYGH. The Hague convention..., cit., p. 17.

${ }^{375}$ PICONE. La nuova convenzione..., cit., p. 716.
} 
garantir o resultado prático da sentença judicial ou da decisão administrativa que afinal se tomará, atingindo-se, assim, o escopo social que o processo ou o procedimento administrativo devem ter e que, nessa seara das relações humanas é muito claro: o melhor interesse da criança ${ }^{376}$.

Admite-se, ainda, "comme le miroir de l'art. 8",377, que um Estado tido por incompetente, mas que gostaria de prover a criança de uma medida de proteção que considera adequada e conforme o melhor interesse do infante, requeira autorização do Estado competente, via autoridades centrais, para que possa ele, Estado até então incompetente, decidir a questão nos termos do art. $9^{\circ}$.

Por fim, a convenção atribui competência para as autoridades judiciárias ou administrativas do local onde a criança se encontra a fim de decidirem sobre medidas urgentes ou mesmo sobre medidas outras de proteção, sendo certo que, nesses casos, as medidas são, em certa medida, provisórias, já que cedem diante de medidas tomadas por autoridades de outros Estados cuja situação seja mais privilegiada à luz das disposições da convenção sobre distribuição de competência. Assim, por exemplo, no que concerne às crianças refugiadas em razão de catástrofes naturais ou conflitos bélicos que tenham atingido seu Estado de residência habitual. As autoridades do local de sua situação atual terão sua competência reconhecida para a adoção de medidas protetivas ao abrigo da convenção até que se venha a firmar nova residência habitual para a criança ou até que ela recupere sua residência originária (art. 6,1 , c/c arts. 11,2 e 11, 3) ${ }^{378}$. O mesmo se passa nas hipóteses de crianças residentes habitualmente em Estados não contratantes e que necessitem de medidas de proteção no período em que estejam localizadas no território um Estado contratante ${ }^{379}$.

Quanto à determinação da lei aplicável, há que se diferenciar duas situações: de um lado, a lei aplicável para reger a atribuição, manutenção ou regulação do poder familiar (autoridade paternal), independentemente da intervenção de uma autoridade judicial ou administrativa e, de outro, a lei aplicável para reger quaisquer medidas de proteção

\footnotetext{
376 Esse interesse passa também, pela pronta transformação do litígio, o que autoriza que o Estado da residência habitual da criança julgue a demanda, ainda que não se considere a jurisdição mais apropriada, diante da demora apresentada pelo Estado requerido em responder à provocação da autoridade central do Estado requerente, a respeito da conveniência de se transferir a competência nos termos da convenção. Nesse sentido: LAGARDE. La nouvelle convention..., cit.; PICONE. La nuova convenzione..., cit., p. 716, nota 32.

${ }^{377}$ BUCHER. L'enfant..., cit., p. 182.

378 BUCHER. L'enfant..., cit., p. 179.

${ }^{379}$ BUCHER. L'enfant..., cit., p. 180.
} 
estabelecidas em favor da criança.

Segundo a convenção de 1996, a atribuição, manutenção ipso facto e, em qualquer desses casos, a regulação do poder familiar, por expressa disposição legal ou por acordo havido entre as partes, independentemente de qualquer provimento judicial (inclusive homologação do acordado), reger-se-á pela lei da residência habitual da criança, não se prevendo elementos de conexão subsidiários. Tal regra deflui do art. 16 da convenção de 1996 que, com o intuito de jogar pá de cal sobre intensa discussão doutrinária travada acerca da natureza do art. $3^{\circ}$ da convenção de 1961, construiu-se sob autêntica conformação de regra de conflito de leis, determinando a aplicação da lei da residência habitual da criança. Nesse sentido, nas hipóteses em que houver modificação da residência habitual da criança, poderá ocorrer alteração da lei de regência da hipótese, determinando nova regulação para o instituto do poder familiar.

Imaginem-se, assim, algumas hipóteses ${ }^{380}$. Na primeira, a alteração da residência habitual esbarra na constatação de que o poder familiar nascido de pleno direito à luz da lei aplicável (antiga residência habitual da criança) não existe segundo a nova lei aplicável. Nesse caso, assegura-se a continuidade da lei primitiva e mantém-se a autoridade parental de fato anteriormente existente, até que haja provimento jurisdicional ou administrativo posterior que regule a questão distintamente (art. 16.3). Na segunda hipótese, a situação criada e regulada pela lei anteriormente aplicável está contida na regulação da nova lei aplicável. Nessa situação tanto poderá haver coincidência regulamentar como poderá ser o caso da nova lei ser mais adequada aos interesses da criança. Em qualquer caso, aplica-se a lei da nova residência habitual da criança (art. 17). Por fim, na hipótese de a lei da nova residência contemplar o instituto, mas atribuí-lo a outro legitimado, entende a doutrina que tal lei deverá ser aplicada, modificando-se a titularidade da autoridade parental, ipso facto da alteração da residência habitual da criança ${ }^{381}$.

Quanto à determinação da lei aplicável às medidas de proteção, esta será a lei do foro competente (normalmente a residência habitual da criança, convertida em centro de vida e de interesse do infante ${ }^{382}$ ) segundo as determinações do Capítulo II da convenção, podendo, no entanto, o Estado competente optar, no melhor interesse da criança, pela

\footnotetext{
${ }^{380}$ Para o que segue: HERRANZ BALLESTEROS. El interés..., cit., p. 135-136.

${ }^{381}$ LAGARDE. La nouvelle convention..., cit., p. 231-233; HERRANZ BALLESTEROS. El interés..., cit., p. 136.

${ }^{382}$ MOURA RAMOS. La protección..., cit., p. 78.
} 
aplicação da lei que apresentar vínculos mais estreitos com a questão a respeito da qual se deve decidir ${ }^{383}$. Isso por que nem sempre a lei do foro competente (autoridade melhor situada para a tomada de decisão) é a lei mais indicada a satisfazer os interesses da criança $^{384}$.

No que concerne à deslocação da competência do Estado da residência habitual da criança para o Estado que estiver decidindo acerca de qualquer das medidas aptas a por fim ao relacionamento vivido pelos pais da criança e a conseqüente aplicação desta lei (lex fori), a solução trazida pela convenção enfrentou resistências, tendo as delegações da Espanha e da Suíça sugerido que, nesse caso, a lei aplicável fosse a lei da residência habitual da criança. A proposta, entretanto, foi afastada, pois a convenção que se estava então a negociar perseguia e vinha conseguindo, até então, fazer coincidir foro competente e lei aplicável ${ }^{385}$.

Nos casos em que sobrevier alteração da residência habitual, a convenção prevê que as medidas anteriormente determinadas pela autoridade competente, com base na lei então aplicável, devem subsistir e ser aplicadas pelo Estado da nova residência habitual. O mesmo acontecerá nas hipóteses em que a competência tiver sido transferida para outro Estado considerado mais próximo à criança e melhor preparado para a tomada da decisão. Assim, o Estado da residência habitual, ao transferir sua competência originária para Estado outro, fica adstrito a tal iniciativa e deve, por isso, respeitar a decisão havida alhures, tomada segundo a lex fori ou segundo outra lei, julgada mais pertinente pela autoridade que decidiu a questão. Obviamente, essa obrigação que se impõe ao Estado da residência habitual da criança (de respeitar a decisão havida por outra autoridade que não a sua nas hipóteses previstas na convenção) só subsistirá enquanto a causa de pedir permanecer inalterada. Vale dizer: havendo alteração das condições fáticas, poderá o Estado da residência habitual (na segunda hipótese) ou o da nova residência habitual (na primeira hipótese) examinar novo pedido em seu foro e segundo a aplicação de sua lei, alterando ou não as medidas de proteção e exercício da autoridade parental até então vigentes $^{386}$.

No que diz respeito ao reconhecimento e execução das decisões havidas pelos Estados

\footnotetext{
${ }^{383} \mathrm{O}$ que se deve à proposta apresentada, ainda durante a comissão especial, pela delegação italiana. Cf. PICONE. La nuova convenzione..., cit., p. 730-731.

${ }^{384}$ HERRANZ BALLESTEROS. El interés..., cit., p. 124.

${ }^{385}$ HERRANZ BALLESTEROS. El interés..., cit., p. 125-126.

${ }^{386}$ NYGH. The Hague convention..., cit., p. 22-23.
} 
competentes segundo as disposições da convenção, cumpre destacar a ampla proposta estadunidense no sentido de tornar passível de reconhecimento e execução as decisões provenientes de Estados não partes, o que foi rechaçado pelos Estados negociantes, nos moldes propostos, porquanto se tenha sempre em mente a situação de serem os acordos de reconhecimento e execução baseados na reciprocidade ${ }^{387}$. No entanto, poderá um Estado parte reconhecer e executar qualquer medida de proteção tomada por um Estado não parte, desde que a criança que se visa proteger seja residente habitualmente neste Estado e nacional daquele, hipótese em que o primeiro Estado poderá dispensar a homologação da sentença estrangeira, no melhor interesse da criança ${ }^{388}$.

Há hipóteses em que o reconhecimento e a execução podem ser negados pelo Estado requerido. No entanto, as hipóteses que permitem o não reconhecimento não são peremptórias, podendo o Estado requerido reconhecer a decisão havida em outro Estado, se com ela concordar quanto ao fundo. As hipóteses que autorizam o não reconhecimento das decisões são, de um lado, a ausência de oitiva da criança e/ou do titular da autoridade parental, salvo se tal dispensa tenha se justificado em razão da urgência presente na requisição e adoção da medida que se busca reconhecer e, de outro, a manifesta ofensa à ordem pública do estado requerido, devendo-se, nesse caso, ter em conta o melhor interesse da criança.

Por fim, decisões que determinem a instituição da kafala em outro Estado contratante em que o instituto seja desconhecido só serão executáveis se tiverem sido objeto de pedido dirigido ao Estado sob cuja jurisdição a kafala deverá ser cumprida precedente da autoridade central do Estado que tomou a medida ${ }^{389}$.

\footnotetext{
${ }^{387}$ A esse respeito: HOUTTE, Hans van. La réciprocité des règles de conflit dans les conventions de la Haye. Revue Belge de Droit International, Bruxelles, v. 24, n. 2, p. 491-503, 1991; LAGARDE, Paul. La réciprocité en droit international privé. Recueil des Cours, Alphen aan den Rijn: Sijthoff \& Noordhoff, v. 154, p. 103-214, 1977; COSCIA, Giuseppe. Condizione di reciprocità e diritto internazionale privato. Rivista di Diritto Internazionale Privato e Processuale, Padova, v. 37, n. 3, p. 557-568, 2001; MENGOZZI, Paolo. La condizione di reciprocità e il diritto internazionale privato. Rivista di Diritto Internazionale Privato e Processuale,Padova, v. 30, n. 3, p. 485-498, 1994.

388 ITERSON. The New Hague..., cit., p. 479.

${ }^{389}$ NYGH. The Hague convention..., cit., p. 24-25.
} 


\section{A CONVENÇÃO DA HAIA SOBRE OS ASPECTOS CIVIS DO SEQÜESTRO (SUBTRAÇÃ̃O ${ }^{390}$ ) INTERNACIONAL DE CRIANÇAS, DE $1980^{391}$}

Entende-se por subtração internacional de crianças, à luz da Convenção da Haia sobre os aspectos civis do seqüestro internacional de crianças ${ }^{392}$, tanto a retirada de uma criança do poder de quem exercia sua guarda, ipso facto determinada por lei, por decisão judicial ou administrativa ou por acordo legalmente reconhecido, como a não devolução da criança ao poder de quem de direito, após um período no qual a criança exercia o direito de visitar e ser visitada por um parente não guardião.

Assim, tanto pode se dar quando da retirada efetiva da criança do Estado de sua residência habitual, que é, na maior parte das vezes, o Estado da residência habitual de quem exerce legalmente a guarda ${ }^{393}$, como no caso de retenção arbitrária dessa criança em território diverso daquele em que residia.

A referida convenção preocupa-se apenas com os aspectos civis dessa subtração, estabelecendo mecanismos de reclamo e cooperação jurisdicional entre os Estados parte

\footnotetext{
${ }^{390}$ A tradução brasileira fala em seqüestro. Em Portugal diz-se rapto. No entanto, o Bureau permanente sugere que se adote a expressão "subtração internacional". Em visita oficial ao Ministro da Justiça, realizada em 2005, o Secretário Geral da Conferência, Hans van Loon, solicitou a substituição do termo na tradução oficial brasileira. Segundo informações fornecidas pelo Secretário Geral (carta pessoal encaminhada ao Professor João Grandino Rodas, por ele gentilmente cedida para análise quando da realização da pesquisa), o Ministro da Justiça concordou com suas ponderações e assumiu o compromisso de rever a tradução brasileira. Por essa razão, o presente trabalho consignará o termo "subtração", exceto quando se referir ao título, ainda oficial, da convenção. Perceba-se, entretanto, que o transcurso de mais de dois anos desde então demonstra que nenhuma medida oficial foi tomada.

${ }^{391}$ Muitas das idéias expostas neste tópico provêem da pesquisa realizada, em outro contexto, quando do curso de mestrado, na Universidade de Coimbra, agora ampliada, atualizada e adaptada a novo contexto.

392 Atualmente a convenção vigora entre quase todos os Estados membros da Conferência da Haia de Direito Internacional Privado, ou seja, África do Sul, Albânia, Alemanha, Argentina, Austrália, Áustria, BieloRússia, Bélgica, Bósnia-Herzegovina, Brasil, Bulgária, Canadá, Chile, Chipre, Croácia, Dinamarca, Equador, Eslováquia, Eslovênia, Espanha, Estônia, Estados Unidos, Finlândia, França, Geórgia, Grécia, Holanda, Hong Kong, Hungria, Irlanda, Islândia, Israel, Itália, Letônia, Lituânia, Luxemburgo, Macau, Macedônia, Malta, México, Mônaco, Montenegro, Noruega, Nova Zelândia, Panamá, Paraguai, Peru, Polônia, Portugal, República Tcheca, Romênia, Reino Unido, Sérvia, Sri Lanka, Suécia, Suíça, Turquia, Ucrânia, Uruguai e Venezuela, não vigorando, entretanto, para Coréia do Sul, Egito, Índia, Japão, Jordânia, Malásia, Marrocos, Rússia e Suriname. Aderiram a suas disposições, no entanto, os seguintes Estados não membros da Organização: Armênia, Bahamas, Belize, Burkina Faso, Colômbia, Costa Rica, El Salvador, Guatemala, Honduras, Ilhas Fidji, Ilhas Maurício, Ilhas San Kit e Neves, Moldávia, Nicarágua, República Dominicana, San Marino, Tailândia, Trinidad e Tobago, Turcomenistão, Uzbequistão e Zimbábue. Está em período de vacatio legis, ainda, para as Ilhas Seicheles. Fonte: http://hcch.e-vision.nl/upload/statmtrx_f.pdf Último acesso em 23.09.2008.

393 "This treaty recognizes that frustration of meaningful visitation rights is an important cause for parental kidnappings. Thus it encourages co-operation between the designated authorities in the different countries to set up transnational visitation while at the same time removing the uncertainty by providing guarantees of the child's return at the end of the visitation period". DYER. Protecting the right..., cit., p. 412.
} 
com o intuito de facilitar o retorno da criança ao Estado de sua residência habitual, de forma rápida e menos traumática possível ${ }^{394}$. O conteúdo da convenção é diverso da grande maioria dos tratados sobre direito internacional privado, porquanto não estabeleça regras sobre lei aplicável ${ }^{395}$, não regulamente o procedimento de obtenção de exequatur de decisão estrangeiras, não mencione decisões relativas à atribuição da guarda, podendo por isso ser chamado de "un convenio 'fuera de lo normal', un convenio sui generis"396. Quanto aos aspectos criminais desse ato, várias são as razões para sua não regulamentação pela sociedade internacional, os quais foram bem sintetizados por Geraldine van Bueren, ao afirmar que

"the intention behind the private international law is not to take children permanently away from their abductors but to restore a situation in which children may have as regular an acess as possible bearing in mind that the parents live in different states. For these reasons neither treaty focusses on the penal punishment of the abductor. This is not only because the paucity of international criminal law but also because international child abduction is a difficult situation which criminalisation may aggravate and drive the abductor and abducted child further into hiding" 397 .

Estimava-se que, antes de 1980, os casos de subtração de crianças giravam em torno de 25.000, nas estatísticas mais conservadoras, chegando-se a previsões de 400.000, nos levantamentos mais pessimistas ${ }^{398}$. Do ponto de vista das ciências matemáticas, notadamente da estatística, essa amplitude entre os números apresentados tem significação muito clara: denotam completa incerteza quanto aos dados mensurados.

$\mathrm{Na}$ base dos fatos jurídicos estão fatores sociológicos como a liberalização e flexibilização da família e do casamento, o avanço das comunicações, os conflitos de

\footnotetext{
394 HELZICK, Cathy S. Returning United States children abducted to foreign countries: the need to implement the Hague Convention on the Civil Aspects of International Child Abductions. Boston University International Law Journal, p. 119-152, 1987 (HeinOnLine).

${ }^{395}$ Em sentido contrário, afirmando que a convenção determina, ao menos, a lei aplicável para se verificar se a subtração foi lícita ou ilícita, SCHUZ, Rhona. The Hague child abduction convention: family law and private international law. International and Comparative Law Quarterly, London, v. 44. n. 4, p. 771-802, oct. 1995 , p. 796.

${ }^{396}$ BORRÁS, Alegría. Practica española en aplicación del Convenio de La Haya de 1980 sobre sustracción internacional de menores. In: La sustracción internacional de los menores (aspectos civiles) - II Jornadas de D.I.P. (Patronato Universitario de Toledo), p. 81-93, p. 95. Separata fornecida pela Conferência da Haia de Direito Internacional Privado, sem indicação do ano de publicação.

${ }^{397}$ BUEREN. The international law..., cit., p. 91.

${ }^{398}$ Conferir essas informações em SHAPIRA, Amos. Private International Law aspects of child custody and child kidnapping cases. Recueil des Cours, La Haye, n. 214, p. 127-250, 1989, p. 177.
} 
cultura e civilização, os movimentos migratórios e os desequilíbrios econômicos e, também, fatores jurídicos que estabelecem mecanismos de deslocação das crianças, sem a consideração de seus próprios interesses. Para tanto, seria necessário proporcionar certa estabilidade à criança, procurando manter seu convívio com ambos os genitores ${ }^{399}$.

A adoção dessa convenção, por outro lado, facilita a troca de informações entre os Estados parte, que são muitos ${ }^{400}$, permite uniformização do tratamento dos dados estatísticos compilados ${ }^{401}$ e garante pronta atitude interestatal no sentido de fazer volver a criança ao Estado de sua residência habitual. Além disso, deve-se ressaltar a natureza autoexecutória da convenção, o que torna desnecessária a elaboração de normas internas para que seja praticamente observada nos Estados que aderem a suas disposições ${ }^{402}$.

Quanto ao âmbito de proteção da referida convenção, saliente-se que, apesar de prever sua aplicabilidade apenas até os dezesseis anos de idade da criança subtraída ${ }^{403}$, fato é que já se reconheceu a possibilidade de aplicação dos mecanismos dessa convenção, por decisão unilateral do Estado requerido, ainda que a criança conte 16 anos ou mais. Isso porque não resta claro no texto da convenção qual o dies ad quem para a aplicabilidade de suas disposições: se se trata da data da subtração ou da data do pedido de busca e apreensão. Também não fica claro se essa situação é relevante, hipótese em que seria forçoso concluir que o cumprimento da idade em qualquer fase do procedimento impediria a contínua aplicabilidade da convenção ${ }^{404}$. Por tal razão, defende-se que a convenção se

\footnotetext{
${ }^{399}$ BORRÁS RODRÍGUEZ. El "interes del menor"..., cit., p. 952-953.

400 Esta convenção da Haia é a terceira maior convenção de direito internacional privado em número de ratificações ou adesões (atrás da convenção sobre apostille e da convenção de Nova York sobre reconhecimento de laudos arbitrais), muito embora estas ratificações sejam em número muito inferior às da convenção de 1989 sobre os direitos da criança. As razões para tanto podem ser encontradas em DYER, Adair. A convenção da Haia sobre os aspectos civis do rapto internacional de crianças - para uma cooperação global. Os seus sucessos e insucessos. Trad. Teresa Trigo de Sousa. Infância e juventude, Lisboa, n. 3, p. 9-36, 1994, e são basicamente as seguintes: as maiores e mais específicas restrições e obrigações impostas aos Estados que a ela adiram, em comparação com a convenção guarda-chuva de 1989. Informam BALFOUR, Ian L. S.; CRAWFORD, Elizabeth B. The Hague Convention on International Child Abduction. Recent Scottish Cases. Scottish Law \& Practice Quarterly, v. 1, n. 5, p. 411-423, Oct 1996, p. 411, o posicionamento de Anton, no sentido de que essa convenção jamais seria considerada bem sucedida pela excelência de suas disposições, mas, sim, pelo número de ratificações e adesões que pudesse amealhar. Isso porque, em princípio, duvidava-se que pudesse receber muitas ratificações ou adesões. $\mathrm{O}$ Brasil aderiu a seu texto no ano 2000 (texto aprovado pelo Decreto Legislativo n. 79, de 15 de setembro de 1999 e promulgado pelo Decreto Executivo n. 3.413, de 14 de abril de 2000).

401 DUNCAN, William. A actuação em apoio da convenção da Haia: ponto de vista do secretariado permanente. Trad. Pedro Miguel Duarte. Infância e Juventude, Lisboa, n. 4, p. 9-34, 2001, p. 14 et seq.

402 BORRÁS RODRÍGUEZ. El "interes del menor"..., cit., p. 957.

${ }^{403}$ Em clara antecipação da regra do art. $1^{\circ}$ da Convenção sobre os direitos da criança.

404 Nesse sentido, CARELLA, Gabriella. La convenzione dell'Aja del 1980 sugli aspetti civili della sottrazione internazionale di minori. Rivista di Diritto Internazionale Privato e Processuale, Padova, v. 30, n. 4, p. 777-794, 1994, p. 781.
} 
aplique ainda que, no transcurso da subtração, a criança complete dezesseis anos de idade.

Várias são as hipóteses práticas de configuração da subtração internacional. Tanto pode ocorrer pela retirada da criança da companhia de seu guardião (legal ou convencional) e subsequiente traslado para fora do território do Estado onde a criança residia habitualmente, como pode se dar na hipótese em que a criança se encontra fora de sua residência habitual, em companhia de parentes e com o consentimento de seu guardião ${ }^{405}$, e, no momento aprazado para seu retorno ao lar, os parentes visitados recusam-se a devolvê-la ao guardião. O traço comum, portanto, é a retenção ilícita da criança em local que não seja o de sua residência habitual, na companhia de outro parente que não seu guardião. Bem por isso, informa Gabriella Carella que o:

"Oggetto di tutela è solo la violazione dei diritti di affidamento, non altresí del diritto di visita per cui non può considerarsi sottrazione illecita il caso in cui l'affidatario sposti all'estero la residenza del minore impedendo l'esercizio del diritto di visita" $" 406$.

A hipótese imaginada pela autora não configura retenção ilícita, por certo, mas não se deve afirmar, peremptoriamente, que o direito de visita não esteja resguardado pela convenção. É verdade que explicitamente não há qualquer menção, mas acredita-se e defende-se a possibilidade de interpretação analógica da convenção ${ }^{407}$ que passaria a abarcar outra hipótese: a do não guardião que vive no exterior e, chegado o período de visitas, encontra recusa imotivada do guardião em permitir o exercício de seu direito-dever. Nesse caso parece-me configurada a hipótese de retenção ilícita, devendo-se aplicar analogicamente a convenção, se esta for vigente entre os Estados envolvidos na situação fática $^{408}$.

Quando ambos os pais possuem a guarda de forma conjunta, nenhum deles poderá deslocar-se para outro território em companhia da criança, sob pena de configurar subtração internacional, salvo na hipótese de ter havido acordo de vontades consubstanciado na autorização de deslocamento da criança.

\footnotetext{
405 Consentimento expresso e real, obviamente. Não se trata de consentimento ficto, presumido, ou obtido mediante coação ou falsificação. A respeito da alegação de existir consentimento, no mais das vezes falso, na defesa apresentada no procedimento de busca e apreensão, BALFOUR; CRAWFORD. The Hague Convention..., cit., p. 419-420.

${ }^{406}$ CARELLA. La convenzione dell'Aja..., cit., p. 783, nota 14.

407 Salutar, assim, para evitar o recurso analógico, a proposta formulada em maio de 2000 pelas delegações da Austrália, Espanha, Reino Unido e Estados Unidos para elaboração de um protocolo adicional à convenção de 1980, a fim de garantir o direito de acesso dos não-guardiões às crianças.

${ }^{408}$ Ver, no item seguinte deste capítulo, o sistema imaginado pela CIDIP.
} 
Verificada a configuração da subtração, cabe ao guardião lesado (ou a qualquer outra pessoa, instituição ou organismo interessado) requerer providências junto a autoridade central do Estado de residência habitual da criança ou de qualquer outro Estado contratante, que deverão, cientes do fato, diligenciar junto a sua homóloga na sede do Estado onde a criança se encontrar retida de forma ilícita, requerendo a devolução do infante ao Estado de sua residência habitual. No Brasil, o órgão que cumpre tal função é a Secretaria Especial dos Direitos Humanos ${ }^{409}$.

Segundo determinação da convenção, o pedido deve conter as informações necessárias sobre a identidade do requerente, da criança e da pessoa a quem se atribui a transferência ou a retenção ilícitas, a data de nascimento da criança subtraída, quando possível, os motivos em que o requerente se baseia para exigir o retorno da criança ao Estado de sua residência habitual, ou seja, um sumário dos fatos que possa configurar a causa de pedir, bem como todas as informações disponíveis relativas à localização da criança e à identidade da pessoa com a qual se presume que a criança esteja ${ }^{410}$. A convenção prevê, ainda, como forma de auxiliar na colheita das informações, que o requerente complemente o seu pedido com a cópia autenticada de qualquer decisão ou acordo considerado relevante, como a sentença judicial que tenha fixado a guarda segundo as disposições da lei aplicável ao caso ou o acordo extrajudicial havido entre os genitores da criança, quando permitido pela legislação aplicável. É conveniente, ainda, que se junte ao pedido atestado ou declaração emitida pela autoridade central, por qualquer outra entidade competente no âmbito do Estado da residência habitual da criança, ou por pessoa qualificada, que ateste a vigência e o teor da legislação de tal Estado relativa à matéria, além de outros documentos considerados relevantes. Isso porque a lei aplicável será a lei do estado de origem da criança, aqui entendido como o Estado em que reside habitualmente ${ }^{411}$.

Cumpre ressaltar que o direito de guarda pressupõe, segundo disposição da convenção, o direito de fixar a residência habitual da criança ${ }^{412}$. Assim, se o genitor guardião decidir

\footnotetext{
409 Autoridade Central Administrativa Federal - ACAF; Secretaria Especial dos Direitos Humanos; Presidência da República; Esplanada dos Ministérios; Edifício T, sala 212; 70064-900 BRASILIA D.F.; Brasil; Tel.: +55 (61) 4293975 / 429 3481; Fax: +55 (61) 4292361 / 2267980

410 "Hay países que envían unas solicitudes y una documentación modélica, no es siempre ése el caso. Hay casos en que no resulta claro ni la petición ni la documentación”. BORRÁS. Practica española..., cit., p. 87.

${ }^{411} \mathrm{Ou}$, nos dizeres de JAYME. Identité culturelle..., cit., p. 187, a lei do local a que a criança está ligada por razões de ali desenvolver sua identidade cultural.

${ }^{412}$ Em alguns países da América Latina, a fixação da residência habitual da criança é uma decorrência do poder familiar e não da guarda, o que obriga a que se consiga a autorização do outro genitor para a alteração da residência.
} 
deixar o Estado onde tem a sua residência habitual, para se fixar em outro Estado, haverá alteração, conseqüentemente, da residência habitual da criança. Como já ressaltado supra, o genitor não guardião não poderá reclamar o retorno da criança ao Estado de sua residência habitual ${ }^{413}$, a menos que também ele seja, de fato ou de direito, detentor da guarda. Mas havendo uma decisão judicial ${ }^{414}$, administrativa ou convencional, que atribua a guarda unilateral, será lícito alterar a residência da criança, mesmo se esta alteração dificultar o exercício do direito de visitar e ser visitado. Em isso ocorrendo, poderá o genitor que se sentir prejudicado, demandar judicialmente a alteração da guarda, fazendo-o segundo as regras de direito interno mandadas aplicar pela norma de direito internacional privado.

Configurada a subtração internacional da criança, incumbirá à autoridade judicial decidir a respeito de sua devolução ao Estado da residência habitual ou não. Há disposição expressa na convenção a respeito da impossibilidade de se indagar sobre eventual ambientação da criança no Estado onde se encontra, se a subtração tiver ocorrido a menos de um ano. Todavia, tendo perdurado por mais tempo em decorrência da inércia do guardião ou das dificuldades por ele vivenciadas para descobrir o paradeiro de sua prole, poderá a autoridade responsável pela decisão perquirir a respeito da boa ambientação da criança em seu novo local de residência, estudo, lazer, às novas amizades etc ${ }^{415}$. Em qualquer das hipóteses, no entanto, poder-se-á afastar a aplicação da convenção em algumas específicas hipóteses previstas nos artigos 12, alínea 2, 13 e 20 da convenção. Tais situações permitem que a autoridade competente ${ }^{416}$ recuse-se a determinar o pronto

${ }^{413}$ CARELLA. La convenzione dell'Aja..., cit., p. 783, nota 14.

414 Segundo a convenção, a competência para decidir a respeito da atribuição da guarda ou de sua modificação é do Estado da residência habitual da criança. Percebe-se, assim, que esta convenção guarda sistematicidade quando interpretada juntamente com a convenção de 1996, chegando BUCHER. L'enfant..., cit., p. 196, a afirmar que "la Convention sur l'enlèvement d'enfants doit son existence principalement à l'absence d'un mécanisme d'exécution de décisions sur la garde de l'enfant. Dans la mesure ou la nouvelle Convention [1996] comble cette lacune, elle exerce nécessairement une certaine influence sur le rôle futur de la Convention de 1980". Isso porque, segundo o autor, os motivos de recusa para a entrega da criança subtraída previstos pela convenção de 1980 (arts. 12, alínea 2, 13 e 27) são mais rígidos que os da convenção de 1996.

415 Coerentemente, a convenção de 1996, baseada no princípio da residência habitual, entende que decorrido o lapso temporal de um ano e tendo havido integração ao ambiente em que se encontra ilicitamente, há a fixação de nova residência habitual, deslocando a competência para a tomada de medidas de proteção do Estado em que originalmente residia a criança para o Estado onde passou a residir. A respeito: MOURA RAMOS. La protección..., cit., p. 74.

416 BUCHER, Andreas. La famille en droit international privé. Recueil des Cours, The Hague/Boston/London, v. 283, p. 9-186, 2000, p. 162 et seq., detectou a inexistência de critérios seguros na convenção para a determinação da autoridade competente para conhecer e julgar essa questão relativa à guarda da criança, afirmando que, quando a criança não for mais residente habitual do Estado em que se encontrava anteriormente, seria muito difícil argumentar para comprovar a competência desse Estado. 
regresso da criança ao Estado de sua residência habitual, levando em consideração aspectos que podem determinar ou pelo menos aconselhar a manutenção da criança subtraída no local e na condição em que ela se encontra atualmente ${ }^{417}$.

É interessante notar que um desses fatores (art. 20) diz respeito à concepção de direitos humanos do Estado em que a criança se encontra, o que pode levar o intérprete a acreditar que se trate de uma exceção de ordem pública vigente no Estado requerido, que, dessa forma, se recusaria a cumprir a ordem de imediato regresso da criança a seu Estado de origem. Todavia, uma interpretação histórica permite concluir que não é disso que se trata, uma vez que a exceção de ordem pública fora proposta quando das negociações e retirada, logo em seguida, diante da diversidade de culturas e filosofias envolvidas na questão, o que dificilmente garantiria a aprovação de tal exceção ${ }^{418}$. A fórmula utilizada pela convenção, no entanto, põe em choque, muitas vezes, culturas díspares a respeito, por exemplo, da importância dos cuidados maternos para o desenvolvimento da criança (cultura ocidental, v.g.) e da necessidade da presença paterna e de sua autoridade para a formação do caráter do infante (cultura islâmica, v.g. ${ }^{419}$ ).

Existe um reclamo geral na sociedade internacional a respeito do uso indiscriminado das exceções do art. 13 por parte dos juízes dos Estados parte requeridos. Como a redação das hipóteses contidas no art. 13 é aberta, o problema encontra-se presente, mormente quando se tem em mente o fato de que

"many such removals are made to countries where the abducting parent has

Nesse sentido, mostra-se importantíssima a complementação do sistema pela assunção da convenção de 1996. O problema, parece, reside mais na determinação do que seja residência habitual, aspecto que escapou às considerações da convenção referida, como de resto, das demais Convenções da Haia. Cf. DOLINGER. A criança..., cit., p. 249-250.

417 Cf. PAIS, Marta Santos. Enfants deplaces: comment garantir leur droit a une vie de famille. Documentação e Direito Comparado: Boletim do Ministério da Justiça, Lisboa, n. 65-66, p. 79-88, 1996, p. 85. Para a verificação de decisões jurisprudenciais a respeito das exceções mencionadas, veja-se BRUCH, Carol S. Casos de rapto internacional de crianças: experiência ao abrigo da Convenção da Haia de 1980. Trad. Teresa Trigo de Sousa. Infância e Juventude, Lisboa, n. 3, p. 35-63, 1993, p. 38-47. Da mesma autora: BRUCH, Carol S. O rapto civil de crianças e os tribunais ingleses. Trad. Maria Ana do Canto e Castro; Teresa Trigo de Sousa. Infância e Juventude, Lisboa, n. 4, p. 63-81, 1993. Ainda, porém restrita aos casos de 1996 no Reino Unido, a análise de LOWE, Nigel; PERRY, Alison. International child abduction: the English experience. International and Comparative Law Quarterly, London, v. 48, n. 1, p. 127-148, 1999.

${ }^{418}$ Cf. DOLINGER. A criança..., cit., p. 252. Sobre as discussões que recusaram a fórmula "principes du droit de la famille et de l'ordre public" do Estado requerido, BATIFFOL, Henri. La quatorzième session de la Conférence de La Haye de Droit International Privé. Revue Critique de Droit International Privé. Paris, v. 70 , n. 2, p. 231-245, 1981, p. 234.

419 Cf., por todos, BARONTINI, Giovanni. Dissolução do vínculo conjugal no âmbito internacional. Dissertação de mestrado apresentada à Faculdade de Direito da Universidade de São Paulo, sob orientação do Professor José Carlos de Magalhães, 1998. 
citizenship while the custodial parent does not. The potent appeal of nationality may well influence a local court's decision that the child should remain with the abducting parent" ${ }^{420}$.

$\mathrm{Na}$ tentativa de evitar que esta solução se torne indiscriminada, a convenção estabelece que o juiz poderá se recusar a devolver a criança ao Estado de sua residência habitual em poucas hipóteses. A primeira possibilidade que lhe é aberta consiste no convencimento de que a pessoa, instituição ou organismo que tinha a criança subtraída a seu cuidado não exercia, de forma efetiva, o direito de guarda na época em que a criança fora transferida ou retida ilicitamente ${ }^{421}$. O juiz também estará dispensado de determinar a devolução se houver provas de que o guardião havia consentido ou concordado posteriormente com esta transferência ou retenção. O mesmo poderá ocorrer se houver concretas evidências de que existe um risco grave ${ }^{422}$ de que a criança, no seu retorno, ficará sujeita a situação de perigo físico ou psíquico, ou que, de qualquer outro modo, será exposta a situação intolerável ${ }^{423-}$ ${ }^{424}$. Aliás, este aspecto já fora posto em relevo por Elisa Pérez Vera, quando da elaboração

${ }^{420}$ KEARNEY, Richard D. Developments in private international law. American Journal of International Law, Lancaster, v. 81, n. 3, p. 724-739, 1987, p. 732.

${ }^{421}$ Nesse sentido, um caso que se encontra em trâmite na Justiça Federal da $3^{a}$ Região. Na hipótese o pai biológico, estrangeiro, não reconheceu a criança brasileira, nascida no exterior, no Estado da residência habitual da mãe, também ela brasileira. Passando mãe e filho a residir no Estado da nacionalidade do pai, obtiveram, deste, autorização para passar férias no Brasil. Optando por não deixar o território nacional, a mãe foi demandada com base na convenção de 1980. Chamado a opinar sobre a questão, posicionei-me no sentido de que a criança não fosse apreendida e remetida ao exterior, por não ter o pai, autoridade parental sobre a pessoa do filho, que nunca reconhecera. Nesse caso, como não tivesse autoridade parental, nem decisão judicial alguma que lhe concedesse a guarda, não exercia a guarda efetiva da criança quando esta deixou o Estado estrangeiro em direção ao território nacional. No que se refere à competência da Justiça Federal, a mesma se justifica, à luz do Direito positivo, em face da determinação constitucional de competência para julgar matérias relativas a tratados internacionais. Todavia, do ponto de vista do conteúdo da relação jurídica processual, talvez fosse preferível que a questão estivesse sob alçada da justiça estadual, mormente das varas e câmaras especializadas em direito de família, onde houver. No mesmo sentido, relativamente ao direito argentino, invocando a sensibilidade jurídica diferenciada dos juízes de família: MAKIANICH DE BASSET, Lidia Noemi; GUTIERREZ, Délia. L'Argentine et la Convention sur les aspects civils de l'enlèvement international d'enfants. L'enfant et les conventions internationales. Presses Universitaires de Lyon, p. 163-170, 1996, p. 164.

${ }^{422}$ JAYME. Identité culturelle..., cit., p. 192 cita, quanto ao aspecto do grave risco, caso decidido pela jurisprudência alemã em que se negou o retorno da criança à Austrália porque esta não mais compreendia palavras em inglês, nem mesmo as mais simples, como daddy. Citado autor enxergou, na hipótese, sensibilidade do juiz quanto à proteção da identidade cultural da criança. Indaga-se, no entanto, se a subtração ilícita realizada fora capaz de respeitar tal identidade? Infelizmente, os dados apresentados pelo autor não admitem posição conclusiva quanto a tal aspecto.

${ }^{423}$ No caso mencionado na nota 421, o juiz de primeira instância negou a busca e apreensão do garoto, após oitiva das partes e da criança, por considerar que, na hipótese, estaria ela sujeita a situação intolerável, caso retornasse ao exterior.

${ }^{424}$ Segundo LeGETTE, Caroline. International Child Abduction and The Hague Convention: Emerging Practice and Interpretation of the Discretionary Exception. Texas International Law Journal, v. 25, n. 2, p. 287-308, 1990 (HeinOnLine), p. 304 et seq., há casos em que o genitor que subtrai ilicitamente a criança do Estado de sua residência habitual não tem condições de retornar a este Estado. Nesses casos, alguns juízes têm entendido se tratar de hipótese de não aplicação da convenção, pois o afastamento do genitor do 
do relatório final e explicativo a respeito da convenção, chamando a atenção para a necessidade de uma interpretação restritiva das exceções dos artigos 13 e 20, pois, caso contrário, poder-se-ia barrar o progresso que esta convenção representa para a cooperação judiciária internacional $^{425}$.

Para amenizar essa utilização indiscriminada, o Secretariado da Conferência da Haia de Direito Internacional Privado tem promovido conferências para magistrados, incentivandoos ao real conhecimento da convenção, com vistas a sua boa e oportuna aplicação. Até porque, como salienta Alegría Borrás "el convenio establece un procedimiento autónomo y fuera de los cauces de lo conocido, por lo que no es raro que se produzca, en un principio, un cierto caos como consecuencia de se establecer una cooperación fuera de lo normal” ${ }^{, 26}$. Por outro lado, o Bureau permanente da Conferência criou uma base de dados na qual pretende incluir todas as decisões atinentes à convenção, havidas em âmbito mundial ${ }^{427}$. Esta base de dados já se encontra disponível no seguinte endereço na rede mundial de computadores em versões nas línguas inglesa, francesa e espanhola: www.incadat.com ${ }^{428}$.

convívio da criança representaria uma situação intolerável. Não parece, entretanto, que esta causa possa se configurar como exceção à aplicação da convenção, indiscriminadamente. Basta que se imagine situação em que o guardião se comprometa a arcar com os custos do deslocamento internacional das crianças, para que possam exercer, no Estado do não-guardião, o direito de visita que não pode ser exercido no Estado de residência habitual das crianças.

${ }^{425}$ Nesse sentido: JENARD, P. Les enlèvements internationaux d'enfants et l'administration. Revue Belge de Droit International, Bruxelles, v. 21, n. 1, p. 35-59, 1988, p. 49-50.

${ }^{426}$ BORRÁS. Practica española..., cit., p. 87. Mais adiante, a autora afirma que somente a boa aplicação da convenção garantirá que um Estado não se torne um paraíso de seqüestradores (p. 89). Por fim, aduz que o fato de muitos Estados partes aplicarem corretamente, e sem maiores problemas, a convenção (cita a França, a Suíça e o Reino Unido), demonstra que o problema não é intrínseco ao instrumento convencional, mas extrínseco a ele, residindo na forma de aplicação de suas disposições pelos vários Estados parte (p. 93).

427 DUNCAN. A actuação..., cit., p. 11 et seq., especialmente o anexo II do texto. Relativamente às dificuldades de aplicação da convenção em razão das circunstâncias constitucionais de alguns Estados, que impedem a aplicabilidade imediata de convenções desse tipo, veja-se, por todos, o informe de ÁLVAREZ GONZÁLEZ, Santiago. Nuevas "medidas relativas al retorno de menores en supuestos de sustracción internacional" en la ley de enjuiciamiento civil. Revista Española de Derecho Internacional, Madrid, v. 48, n. 1, p. 504-507, 1996. Também o informe de BORRÁS, Alegría. Conferencia de la Haya de Derecho Internacional Privado: tercera reunión de la comisión especial sobre la aplicación del Convenio de la Haya de 1980 sobre sustracción internacional de menores (17 a 21 de marzo de 1997). Revista Española de Derecho Internacional, Madrid, v. 49, n. 1, p. 348-350, 1997, acerca das condições de funcionamento das autoridades centrais. Verificar, ainda, inúmeros documentos a respeito em http://hcch.evision.nl/index_fr.php?act=text.display\&tid=21.

${ }^{428}$ A esse respeito, LOON, Hans van. The Implementation and Enforcement of the Hague Convention of 25 October 1980 on the Civil Aspects of International Child Abduction in comparative perspective: It's Japan's move! Gender Law and Policy Annual Review, v. 2, p. 189-209, 2004, p. 194. 


\section{A CONVENÇÃO INTERAMERICANA SOBRE RESTITUIÇÃO INTERNACIONAL DE MENORES, DE 1989}

Além da convenção da Haia de 1980, a sociedade internacional se preocupou em regrar a temática da subtração internacional de crianças em âmbito regional. Assim, tanto no âmbito regional europeu, como no âmbito regional americano, duas convenções surgiram para regular a questão. A convenção européia foi assinada no Luxemburgo, em maio de $1980^{429}$ e precede, portanto, à convenção da Haia. Já a convenção interamericana veio a lume em 1989, tendo sido assinada em Montevidéu, no Uruguai, sob os auspícios da Organização dos Estados Americanos. No que concerne aos interesses manifestos que o presente trabalho visa atingir, será analisada a convenção de Montevidéu, procurando-se apontar as distinções existentes entre o texto universal de 1980 e este texto regional, já que ambos vigoram no sistema jurídico interno brasileiro ${ }^{430}$.

Os objetivos de ambas as convenções são muito próximos, diferindo, todavia, a extensão de sua regulação ${ }^{431}$. Com efeito, as convenções se preocupam em criar mecanismos que promovam o retorno da criança que haja sido transportada ilegalmente para um Estado parte, provindo de outro Estado parte, bem como daquelas crianças que, tendo sido transportadas de forma lícita, foram, entretanto, retidas ilegalmente em estado diverso daquele em que residem habitualmente. A convenção interamericana, no entanto, amplia seu objeto central ao afirmar expressamente que tem por escopo complementar "fazer respeitar o exercício do direito de visita, de custódia ou de guarda por parte dos titulares desses direitos" (art. $1^{\circ}$ ). Ora, quer isso significar que esta convenção,

\footnotetext{
${ }^{429}$ Cf., com interessante e rica análise da jurisprudência do Tribunal Europeu de Direitos Humanos acerca do tema, SILVA, Nuno Ascensão. Algumas considerações sobre os trabalhos do Conselho da Europa no contexto do movimento de internacionalização do direito de menores - o rapto de crianças e os direitos de guarda e visita nas relações privadas internacionais. Lex Familiae: Revista Portuguesa de Direito de Família, Coimbra, ano 2, n. 4, p. 37-91, 2005.

${ }^{430} \mathrm{O}$ texto da Convenção interamericana sobre restituição internacional de menores foi aprovado pelo Decreto Legislativo n. 3, de 7 de fevereiro de 1994 e promulgado pelo Decreto Executivo n. 1.212, de 3 de agosto de 1994.

${ }^{431}$ Como afirma PARRA-ARANGUREN, Gonzalo. La restitución de menores en el derecho convencional americano. In: Hacia un Nuevo Orden Internacional y Europeo: Estudios en Homenaje al Profesor Don Manuel Díez de Velasco. Madrid: Tecnos, p. 1401-1418, 1993, p. 1408, o título da convenção interamericana não faz expressa referência ao rapto ou ao seqüestro propositadamente, para se evitar a confusão conceitual que a convenção da Haia de 1980 não conseguiu evitar, ou seja, o de não se confundirem os âmbitos civis e penais presentes na hipótese. Até porque, no âmbito Interamericano, há, ainda, uma convenção específica sobre tráfico de menores, assinada em 1994, no México. A respeito: URIONDO DE MARTINOLI, Amalia. Convención interamericana sobre tráfico internacional de menores - CIDIP V - México, 1994. Revista de la Facultad de Derecho y Ciencias Sociales. Universidad Nacional de Córdoba. Córdoba (Argentina), v. 3, n. 1, p. 171-197, 1995.
} 
diferentemente do que se passa com a convenção da Haia de $1980^{432}$, preocupa-se explicitamente com o direito de visitação que privilegia o genitor não guardião e membros da família alargada (artigo 21). Assim, se este for impedido de exercer seu direito de visitas, pela retenção das crianças em companhia do guardião, que obsta de forma deliberada o exercício desse direito, poderá aquele se valer dos mecanismos postos a sua disposição pela convenção em comento ${ }^{433}$. Mormente porque a própria convenção define o direito de visita, afirmando que o mesmo "compreende a faculdade de levar o menor, por período limitado, a lugar diferente do de sua residência habitual" (art. $3^{\circ}$, letra "b") ${ }^{434}$.

À semelhança da convenção de caráter universal, a convenção de 1989 assenta-se sob um sistema de autoridades centrais, coordenadas, todavia, pelo Instituto Interamericano da Criança, órgão especializado da OEA, o que, na visão de Adair Dyer, representa um fator positivo e benéfico no inter-relacionamento dos Estados partes ${ }^{435}$.

Outra distinção importante que merece ser posta em relevo e que emerge da leitura conjunta das convenções mencionadas é a possibilidade de que a autoridade incumbida de analisar o pedido de restituição negue o quanto solicitado diante da oposição da criança envolvida na lide, sempre que a idade e a maturidade do infante justificar que sua opinião seja levada em consideração (art. 11,2).

\footnotetext{
${ }^{432}$ Tanto assim, que em maio de 2000, as delegações da Austrália, Espanha, Reino Unido e Estados Unidos propuseram a elaboração de um protocolo adicional a esta convenção de 1980, a fim de garantir o direito de acesso dos não-guardiões às crianças. Cf. DUNCAN, William. The Hague Conference on Private International Law and its current programme of work concerning the international protection of children and other aspects of family law. Yearbook of Private International Law, The Hague/London/Boston, v. 2, p. 41-54, 2000.

${ }^{433}$ Assim, parece não assistir total razão a BORRÁS RODRÍGUEZ. El "interes del menor"..., cit., p. 959, quando afirma que melhor teriam agido os Estados americanos se tivessem recomendado a ratificação maciça da convenção da Haia, do que elaborar uma convenção geograficamente limitada. Como salientado, ao cuidar do instituto da guarda a convenção da CIDIP afastou-se do objeto literal de regulação global, avançando relativamente àquilo que, somente em 1996 mereceria aprovação na Conferência da Haia de Direito Internacional Privado. Muito embora se tenha defendido, acima, a aplicação analógica da convenção de 1980 às hipóteses de retenção ilícita pelo guardião no momento de se iniciar o período de visitação, força é reconhecer que a convenção da CIDIP é, nesse passo, mais direta.

${ }^{434}$ FERNANDEZ ARROYO, Diego P. Convención interamericana sobre restitución internacional de menores de 15 de julio de 1989. Revista de Informação Legislativa, Brasília, n. 111, p. 139-137, out./dez. 2000.

${ }^{435}$ DYER. Protecting the right..., cit., p. 413.
} 


\section{A CONVENÇÃO DA HAIA SOBRE A LEI APLICÁVEL ÀS OBRIGAÇÕES ALIMENTARES, DE 1973}

Para regular as obrigações alimentares devidas pelos pais aos então denominados filhos legítimos, ilegítimos ou adotivos ${ }^{436}$, bem como pelos avós aos netos e demais parentes em linha reta, excluindo-se qualquer das formas de parentesco em linha colateral, foi assinada no âmbito da Conferência da Haia de Direito Internacional Privado, a Convenção sobre a lei aplicável às obrigações alimentares em favor de crianças, de $1956^{437}$, que virá a ser substituída, em 1973, por outra convenção de escopo mais amplo, posto que aplicável também a relações jurídicas que apresentem um adulto na condição de credor da pensão alimentícia. A contextualização temporal da convenção de 1956 explica a diferenciação que traz a respeito da condição dos filhos, razão pela qual se deve reconhecer que a convenção andou bem ao prever que as obrigações de alimentos podem ser estabelecidas, também, em favor de filhos ilegítimos e adotivos, independentemente do julgamento de questões atinentes ao estabelecimento de filiação, privilegiando a criança nascida fora do casamento que pode haver de seu pai o crédito alimentício a que faça jus ${ }^{438}$.

A lei aplicável para determinar se a obrigação é devida, e em que medida ${ }^{439}$ a a lei da residência habitual das crianças ${ }^{440}$, entendidas no bojo da convenção como toda pessoa humana menor de 21 anos, desde que não seja casada. Segundo disposição convencional, se a criança tiver alterada a sua residência habitual no transcurso da relação alimentar, tal fato dará azo ao reexame da questão, modificando-se, em consequiência, a lei aplicável para a perquirição do quantum da obrigação, configurando, assim, verdadeiro conflito móvel de leis, que acarreta a modificação da lei de regência ${ }^{441}$. Também é a lei da residência habitual que indicará a pessoa a quem se dará incumbência para representar judicialmente o credor

\footnotetext{
${ }^{436}$ DE CESARI, Patrizia. Diritto agli alimenti del figlio naturale, convenzioni dell'Aja e ordine pubblico. Rivista di Diritto Internazionale Privato e Processuale, Padova, v. 10, n. 2, p. 238-259, 1974.

${ }^{437}$ Sobre esta convenção, em especial, BISCARETTI DI RUFFIA, Claudio. Le obligazioni alimentari nel diritto internazionale privato convenzionale. Padova: Cedam, 1989, capítulo III.

${ }^{438}$ Nesse sentido, OVERBECK, Alfred Eugene von. L'image de l'enfant en droit international privé conventionnel. L'image de l'homme en droit. Fribourg: Editions Universitaires Fribourg Suisse, p. 383-403, 1990, p. 391.

${ }^{439}$ Para uma análise a respeito da correlação quantum dos alimentos e ordem pública nas convenções da Haia, veja-se OVERBECK, Alfred Eugene von. L'application par le juge interne des conventions de droit international privé. Recueil des Cours, Leyde, v. 132, p. 1-106, 1971, p. 80-81.

440 "This Convention (...) was a success not only because of the number of countries which ratified it, but also because it led to the transition from the principle of nationality to that of the habitual residence of the child". MARTINY. Maintenance obligations..., cit., p. 162.

${ }^{441}$ MARTINY. Maintenance obligations..., cit., p. 201-202.
} 
de alimentos e quem deve figurar no pólo passivo da demanda, como devedor da prestação alimentícia, além de ser a lei competente para estabelecer os prazos cabíveis para a propositura dos pedidos.

A lei da residência habitual da criança poderá ser afastada, no entanto, por declaração de um Estado contratante que aplicará a lex fori, ou seja, sua própria lei, sempre que todos os elementos da relação alimentícia, com exceção da residência habitual da criança credora estiverem ligados a seu próprio território. Assim, se aquele Estado é o competente para apreciar o pedido, se devedor e credor são seus nacionais e se o devedor mantém sua residência habitual naquele Estado, poderá o mesmo afastar a aplicação da lei estrangeira determinada pela convenção, aplicando, nesse caso, sua própria legislação material. É interessante notar que tal convenção prevê sua aplicabilidade apenas nas hipóteses em que a criança credora dos alimentos for residente em um Estado contratante. Caso contrário, serão aplicáveis as regras de conflito de leis de origem interna do Estado competente para conhecer do pedido. O mesmo ocorrerá, à luz do artigo 3 , se a convenção conduzir à aplicação de uma lei que desconheça o direito à pensão alimentícia ou que simplesmente negue à criança o crédito de que necessita. Nessa hipótese, a própria convenção estabelece que a autoridade competente recorra a suas regras nacionais de regulação do conflito de leis a fim de perquirir se estas não conduzirão à aplicação de outra lei que se mostre mais favorável à criança, reconhecendo seu crédito ${ }^{442}$.

Com a intenção de substituir a convenção de 1956 a respeito do mesmo tema, veio a lume a Convention sur la loi applicable aux obligations alimentaires, ampliando, todavia, o seu plano de atuação subjetivo, como se afirmou acima, para abarcar as obrigações alimentícias devidas em favor de parentes outros que não só os descendentes menores de $21 \operatorname{anos}^{443}$, como era o caso da convenção anterior, entretanto ainda em vigor nas relações entre pessoas provenientes de Estados que não sejam parte, também, na convenção mais recente e não tenham formulado a reserva permitida pelo art. 13.1 da convenção de 1973, e

\footnotetext{
$442 \mathrm{O}$ projeto original previa a aplicação, em qualquer caso, da lei mais favorável à criança. Prevaleceu, todavia, que a exceção à lei da residência habitual do credor só se daria na hipótese mencionada no texto. Cf. DE WINTER, M. L. I. Rapports sur les travaux de la troisième commission (obligations alimentaires), p. 312.

${ }^{443}$ Chegou a ser proposta a regulação de alimentos devidos a títulos diversos que não apenas as relações familiares em sentido amplo, como seria o caso de legados de alimentos, de contratos que estabelecessem a dívida alimentícia ou de indenizações por responsabilidade civil ou criminal que ensejassem a responsabilização alimentícia. Prevaleceu, todavia, a posição que defendia a restrição ao grupo familiar alargado. Cf. FERNÁNDEZ ROZAS. Las obligaciones alimenticias..., cit., p. 80.
} 
que conduz à manutenção plena da convenção de 1956 em vigor ${ }^{444}$.

Contrariamente ao que ocorrera na convenção anterior, que admitia tão-somente a aplicação da lei material de um Estado contratante, esta convenção admite a aplicação da lei de Estados não contratantes, independentemente, portanto, de qualquer condição de reciprocidade $^{445}$.

No que concerne à lei aplicável, esta convenção dá um passo adiante, também, ao prever que, nas hipóteses em que a lei da residência habitual do credor impedir a concessão dos alimentos, estes passem a ser regulados pela lei da nacionalidade das partes, se comum. Por fim, e como critério subsidiário, a convenção determina a aplicação da lex fori e mantém a possibilidade dos Estados contratantes reservarem-se o direito de aplicar sua lei interna nas hipóteses que já eram previstas na convenção de 1956. Percebe-se assim, que por múltiplos fatores é possível estabelecer a conexão do caso à lei do foro ${ }^{446}$.

\section{A CONVENÇÃO DA HAIA SOBRE O RECONHECIMENTO E A EXECUÇÃO DE DECISÕES RELATIVAS A OBRIGAÇÕES ALIMENTARES, DE 1973}

Ao lado das convenções anteriormente analisadas e com o intuito de garantir efetividade às decisões tomadas em algum dos Estados contratantes a respeito das obrigações alimentares, foram assinadas nas mesmas datas das convenções anteriormente referidas, a convenção sobre o reconhecimento e a execução de decisões em matéria de obrigações alimentares em favor de crianças, de $1958^{447}$, e a convenção sobre o

\footnotetext{
444 A convenção de 1956 encontra-se em vigor entre os seguintes países: Alemanha, Áustria, Bélgica, Espanha, França, Holanda, Itália, Japão, Liechtenstein, Luxemburgo, Macau, Portugal, Suíça e Turquia. Poderá, todavia, não ser aplicada se os Estados envolvidos na relação também forem parte na convenção de 1973: Alemanha, Espanha, Estônia, França, Grécia, Holanda, Itália, Japão, Lituânia, Luxemburgo, Polônia, Portugal, Suíça e Turquia. Nenhum desses Estados formulou a reserva mencionada. A respeito: DOMÍNGUEZ LOZANO, Pilar. La determinación de la ley aplicable a las obligaciones de alimentos en el derecho internacional privado español. Revista Española de Derecho Internacional, Madrid, v. 41, n. 2, p. 433-485, 1989, p. 479. Também: http://hcch.e-vision.nl/upload/statmtrx_f.pdf Último acesso em 23.09.2008.

${ }^{445}$ Trata-se, por isso, na visão de MARTINY. Maintenance obligations..., cit., p. 163, de verdadeira lei uniforme sobre determinação do elemento de conexão para a regência da hipótese.

446 Ver, a respeito, AGUILLAR BENÍTEZ DE LUGO, Mariano. La familia en los convenios de la Conferencia de la Haya de Derecho Internacional Privado. Revista Española de Derecho Internacional, Madrid, v. 45, n. 1, p. 7-37, 1993, p. 24-25.

447 A convenção de 1958 está em vigor entre os seguintes Estados: Alemanha, Áustria, Bélgica, Dinamarca, Eslováquia, Espanha, Finlândia, França, Holanda, Hungria, Itália, Liechtenstein, Macau, Noruega, Portugal, República Tcheca, Suécia, Suíça, Suriname e Turquia. Fonte: http://hcch.evision.nl/upload/statmtrx_f.pdf Último acesso em 23.09.2008.
} 
reconhecimento e a execução de decisões relativas a obrigações alimentares, de 1973, as quais procuram dotar as decisões havidas em outros Estados, devidamente esteadas na lei aplicável designada pelas convenções citadas, de imediato reconhecimento e exeqüibilidade em qualquer outro Estado contratante, observadas as condições estabelecidas em seu articulado.

A convenção de 1958, por exemplo, garante o reconhecimento e determina a imediata execução das decisões em matéria de obrigações alimentares ainda que a sentença pendente de eficácia tenha disposto acerca de outras matérias que não a fixação e a condenação ao pagamento de verbas periódicas de natureza alimentar. Ou seja, a eficácia da convenção no sentido de dotar a decisão alienígena de caráter executivo imediato não é afastada por inteiro, mas é afastada exclusivamente quanto às partes da decisão que se refiram a outras matérias que não o crédito alimentício. Assim, apenas tal dispositivo da decisão poderá ser executado desde logo e tal qual nela se contém, devendo as demais determinações da autoridade do Estado de origem ser objeto de prévia homologação, para poderem ser levadas à execução. Da mesma forma, poderá ser executada a decisão provisional, desde que, segundo a lei do Estado onde a decisão foi tomada, esta decisão pudesse ser executada desde logo naquele território.

As decisões de alimentos serão, em qualquer caso, objeto da concessão do exequatur, porém o procedimento é facilitado e há impedimento expresso para qualquer imissão no conteúdo da decisão. Para que o exequatur seja concedido, será necessário observar algumas formalidades estabelecidas pelo art. 4 da convenção, tendentes a garantir a observação, pelo juízo requisitado, de que a decisão que se deseja executar está dotada desde logo de caráter executório. A convenção dispensa, no entanto, qualquer formalidade exacerbada quanto aos documentos que precisam ser encaminhados à execução, dispensando, assim, qualquer forma de legalização ou visto diplomático de tais documentos. No que for omissa, a convenção prevê seja aplicada a lex fori do Estado a quem se requer a execução.

A convenção só obriga o reconhecimento das decisões havidas por autoridades competentes, o que é auferível, segundo seu art. 3, pelo fato de qualquer das partes (credor ou devedor) no procedimento que desencadeou a condenação à prestação de alimentos possuírem residência habitual no território sob jurisdição do Estado a que a autoridade competente esteja vinculada ou, ainda, pelo fato do devedor de alimentos ter se submetido, 
voluntariamente, àquela jurisdição, seja de forma expressa, seja pelo estabelecimento de um procedimento de defesa que não tenha ventilado eventual incompetência da autoridade processante. A residência habitual verifica-se, para os fins mencionados, no exato momento da propositura da demanda.

A determinação de competência prevista na convenção diz respeito não só à condenação original ao pagamento de verba alimentícia, mas também às iniciativas tendentes à revisão do valor a ser pago. Sempre que a decisão condenatória determinar o pagamento de prestações periódicas, a convenção será aplicada para garantir não apenas as verbas vencidas, como também as vincendas à medida que se forem vencendo. Em qualquer hipótese, a norma convencional determina que os Estados parte facilitem a movimentação dos recursos financeiros compreendidos na condenação e objeto da devida execução.

As decisões havidas no Estado de origem serão reconhecidas e executadas, dispõe o art. 2 da convenção de 1958, sempre que tomadas por autoridades consideradas competentes à luz da própria convenção, devendo-se observar, no procedimento tendente à concessão do exequatur, se o requerido foi corretamente citado e se exerceu direito de defesa, pessoalmente ou por representante, ainda que nomeado pela autoridade local (defensor dativo ou equivalente), segundo as determinações da lex fori. Da mesma forma, é preciso que a decisão do Estado de origem tenha transitado em julgado, e que ela não ofenda coisa julgada anteriormente estabelecida no Estado requerido. Da mesma forma, poderá não ser concedida a execução se houver litispendência. Por fim, incompatibilidades manifestas da decisão estrangeira com a ordem pública do Estado requerido impedirão a concessão do exequatur $^{448}$.

Por sua vez, a convenção sobre reconhecimento e execução de decisões relativas às obrigações alimentares, de 1973, objetivou substituir a convenção de 1958 na medida em que regulamenta as mesmas matérias abarcadas por esta última, fazendo-o com ligeiras ressalvas relativamente ao sistema anterior ${ }^{449-450}$. A mais importante distinção entre as duas convenções diz respeito à significativa ampliação do objeto de regulamentação,

\footnotetext{
${ }^{448}$ Ainda, OVERBECK. L'application par le juge..., cit., p. 80-81.

${ }^{449}$ DE CESARI, Patrizia. Le nuove convenzioni dell'Aja in materia di obbligazioni alimentari. Rivista di Diritto Internazionale Privato e Processuale, Padova, v. 19, n. 1, p. 42-68, 1983.

${ }^{450}$ A convenção de 1973 está em vigor entre os seguintes Estados: Alemanha, Austrália, Dinamarca, Espanha, Eslováquia, Estônia, Finlândia, França, Grécia, Holanda, Itália, Lituânia, Luxemburgo, Noruega, Polônia, Portugal, Reino Unido, República Tcheca, Suécia, Suíça e Turquia. Encontra-se, ainda, em vacatio legis para a Ucrânia. Fonte: http://hcch.e-vision.nl/upload/statmtrx_f.pdf Último acesso em 23.09.2008.
} 
preocupando-se a comunidade internacional, agora, com qualquer forma de obrigação de ordem alimentar havida entre os membros de uma família, bem como entre membros de uma sociedade conjugal desfeita ${ }^{451}$. Nesse sentido, a regulação do tema pela convenção perde o foco meramente paternal e se estende a toda forma de assistência devida entre os membros de uma família ${ }^{452}$.

Outra importante modificação no sistema de execução das decisões diz respeito à possibilidade de que órgãos públicos do Estado de origem da decisão busquem se ressarcir, no Estado requerido, das despesas suportadas por eles em razão do adiantamento do valor devido, a fim de garantir a subsistência do credor de alimentos ${ }^{453}$. Nesse caso, subrogando-se no direito da parte credora, a instituição pública poderá, fazendo prova de sua condição de sub-rogado, requerer a execução da decisão em seu favor ${ }^{454}$.

As hipóteses de competência do Estado de origem são ampliadas pela convenção de 1973, deixando de se referir apenas ao foro da residência habitual das partes na relação creditória alimentícia, para atribuir, também, competência ao Estado da nacionalidade de qualquer das partes, credor ou devedor.

Há modificação também no que concerne à previsão de hipóteses em que é possível à autoridade requerida recusar o exequatur à decisão originária, havida em outro Estado contratante. A mais significativa de tais alterações diz respeito não à impossibilidade de se reconhecer e executar a decisão quando há identidade de demandas entre os Estados envolvidos, mas parece residir na parte final do parágrafo 4 do art. 5, na medida em que se admite, ali, forma de recusa à execução de decisão havida em outro Estado, entre as mesmas partes e com o mesmo objeto, se esta decisão puder ser executada no Estado requerido. Quer isto significar que, havendo uma decisão proveniente de um Estado não parte na convenção, e sendo impossível o reconhecimento de tal decisão, por exemplo, em

\footnotetext{
451 "Porquanto não se limite mais às hipóteses de subsistência de menores, a convenção passa a prever mecanismos para a execução de títulos transacionais havidos entre credor e devedor de alimentos". RODAS; MONACO. A Conferência da Haia..., cit., p. 261. Antes, BATIFFOL, Henri. La douzième session de la Conférence de La Haye de Droit International Privé. Revue Critique de Droit International Privé, Paris, v. 62, p. 243-273, 1973, p. 265.

${ }^{452} \mathrm{O}$ que ocasionou problemas relativamente ao direito sueco, que desconhece o dever de alimentos em favor de qualquer pessoa maior de 21 anos, seja qual for a relação de parentesco ou afinidade existente entre elas. De outra sorte, e independentemente da idade, inexiste obrigação entre parentes colaterais. Essas peculiaridades implicaram na aposição de reservas à convenção. Cf. JÄNTERÄ-JAREBORG, Maarit. The influence of the Hague conventions on the development of Swedish family conflicts law. Netherlands International Law Review, The Hague, v. 40, n. 1, p. 49-65, 1993, p. 55-56.

${ }^{453}$ Entre nós, aplaude esta disposição PEREIRA. Prestação de alimentos..., cit., p. 30.

454 MARTINY. Maintenance obligations..., cit., p. 242-244, afirma que "Public bodies [institutions publiques] in this sense also includes private institutions which have to fulfil (sic) public tasks of this type".
} 
razão do não cumprimento de formalidades, pode bem se por a hipótese de concessão do exequatur a outra decisão, havida entre as mesmas partes e sobre o mesmo objeto, que se enquadre nos dispositivos da convenção, mormente por ter sido pronunciada por autoridade que a própria convenção considera competente ${ }^{455}$.

\section{A CONVENÇÃO DA HAIA SOBRE COBRANÇA DE ALIMENTOS DESTINADOS ÀS CRIANÇAS E A OUTROS MEMBROS DA FAMÍLIA}

Percebe-se, pelo exposto nos itens precedentes, que a dualidade de convenções para regular aspectos que defluem da relação jurídica familiar relativa ao pagamento de pensão alimentícia mostra-se nocivo, quanto mais não seja pela possibilidade de que o sistema reste incompleto relativamente a determinados Estados, na medida em que não exista qualquer obrigação dirigida aos Estados parte de uma das convenções, no sentido de tornar-se parte, também, da convenção que tenciona ser-lhe complementar. Acresça-se a essa questão a possibilidade de que os Estados encontrem-se vinculados a uma das convenções firmadas na década de 1950 e a outra convenção da década de 70, além das dificuldades de coordenação relacionadas aos eventuais conflitos de disposições convencionais quando o Estado tenha se tornado parte das duas convenções sobre lei aplicável ou das duas convenções sobre reconhecimento e execução ${ }^{456}$. Além do mais, o objeto destas convenções não consistiu em preocupação exclusiva dos Estados membros da Conferência da Haia de Direito Internacional Privado. As relações que envolvem crédito de natureza alimentar constituíram objeto de preocupação das Conferências Especializadas Interamericanas de Direito Internacional Privado ${ }^{457}$, das Nações Unidas ${ }^{458}$ e do espaço

\footnotetext{
${ }^{455}$ Sobre os problemas práticos decorrentes do funcionamento destas convenções sobre alimentos, veja-se o informe de BORRAS, Alegria. Conferencia de La Haya de Derecho Internacional Privado: reunión de la comisión especial sobre aplicación de los convenios en materia de alimentos (13-17 de noviembre de 1995). Revista Española de Derecho Internacional, Madrid, v. 47, n. 2, p. 498-502, julio/diciembre, 1995.

${ }^{456}$ A esse respeito, ALVAREZ GONZÁLEZ, Santiago. Cláusulas de compatibilidad en los convenios de la Conferencia de la Haya de DIPR. Revista Española de Derecho Internacional, Madrid, v. 45, n. 1, p. 39-62, 1993.

${ }^{457}$ Convenção interamericana sobre obrigação alimentar, concluída em Montevidéu, em 15 de julho de 1989. Aprovada pelo Decreto Legislativo número 1, de 28 de fevereiro de 1996 e promulgada pelo Decreto Executivo 2428, de 17 de dezembro de 1997.

${ }^{458}$ Convenção de Nova York sobre a prestação de alimentos no estrangeiro. Texto aprovado pelo Decreto Legislativo n. 10, de 13 de novembro de 1958 e promulgado pelo Decreto Executivo n. 56.826, de 2 de setembro de 1965 .
} 
regional europeu ${ }^{459}$, sem se mencionar a infinita quantidade de convenções bilaterais sobre a matéria.

Com a intenção de prover o assunto de regulação coerente e condizente com o estágio atual de desenvolvimento não só da matéria em si, mas também dos mecanismos de cooperação judiciária, reconhecimento e execução de decisões estrangeiras criados e implementados pela sociedade internacional, de que são exemplos as convenções de 1980, sobre subtração e de 1993, sobre adoção internacional, a Conferência da Haia de Direito Internacional Privado avocou a si, provocada e apoiada por seus Estados membros, a iniciativa de elaborar texto convencional que pudesse ser dotado de estrutura quádrupla e que, em conseqüência, estabelecesse critérios que determinassem foro competente, lei aplicável, hipóteses de reconhecimento e execução e mecanismos de cooperação judiciária, via comunicação entre Autoridades Centrais. Não sem razão, afirmaram Alegría Borrás e Cristina González Beilfuss que:

"la experiencia que la Conferencia de La Haya ha adquirido respecto a la elaboración y supervisión de la aplicación práctica de instrumentos de cooperación de autoridades en materia de derecho de familia a través de dos de sus grandes éxitos, el Convenio de 1980 de sustracción internacional de menores y el Convenio de 1993 en materia de adopción internacional, hace factible la elaboración de un Convenio de cooperación de autoridades en materia de alimentos funcional y eficaz en un breve lapso de tiempo" ${ }^{, 460}$.

Em que pese o conhecimento acumulado pelos delegados à Conferência da Haia e a conseqüente facilidade relativa por eles encontrada para estabelecer mecanismos apropriados de cooperação judicial no que concerne à cobrança de prestações alimentícias, fato é que as negociações logo se tornaram dificultadas quando se buscaram soluções de compromisso para as disposições relativas à determinação da competência judicial internacional, além dos temas de reconhecimento e execução das decisões judiciais, face à insistência norte-americana no sentido de ser inadmissível, à luz da cláusula constitucional do due process, aceitar a competência do foro da residência habitual do credor de

\footnotetext{
${ }^{459}$ Convenção de Bruxelas (também denominada Bruxelas I) de 24 de Setembro de 1968 e convenção de Lugano de 16 de Setembro de 1988, que tratam da cooperação judiciária, reconhecimento e execução de decisões em matéria civil e comercial, incluindo-se alimentos. O Regulamento "Bruxelas II" aplica-se somente à dissolução do vínculo matrimonial, sem tratar de questões como a culpa dos cônjuges, os efeitos patrimoniais do casamento, as obrigações de alimentos ou outras eventuais medidas acessórias.

${ }^{460}$ BORRÁS, Alegría; GONZÁLEZ BEILFUSS, Cristina. Conferencia de la Haya de derecho internacional privado: comisión especial sobre el cobro de alimentos con respecto a la familia. Revista Española de Derecho Internacional, Madrid, v. 55, n. 1, p. 582-585, 2003, p. 583.
} 
alimentos, solução que encontrava extenso respaldo entre os países europeus e latino$\operatorname{americanos}^{461}$.

As negociações avançaram, tendo havido nova reunião dos Estados membros da Conferência, em Comissão especial, no mês de junho de $2006^{462}$, que se debruçaram sobre um esboço do projeto de convenção, já avançado e relativamente próximo da obtenção do consenso. O comitê de redação se reuniu no mês de setembro de 2006 para adequar seu esboço aos avanços obtidos durante a reunião plenária da Conferência. Em seguida, em finais de 2006, foi a vez do grupo de trabalho nomeado para apresentar propostas relacionadas à lei aplicável se reunir, a fim de avançar novas sugestões relativas aos elementos de conexão subsidiários, a serem respeitados pelos magistrados, sempre que a lei do Estado da residência habitual do credor não permitir que o crédito se configure, restando o necessitado desprovido de meios de subsistência. Nesses casos, o grupo de trabalho composto por uma série de representantes de Estados membros interessados ${ }^{463}$ tem tido extrema dificuldade de fixar os elementos de conexão subsidiários. Pelas propostas apresentadas anteriormente à reunião de junho de 2006, os elementos subsidiários seriam: a lei do foro, qualquer que fosse o foro competente; a lei da residência habitual do devedor (hipótese em que, se esta lei negar o crédito alimentício, aplicar-se-ia a lei da residência habitual do credor, ou seja, a regra geral); ou, a lei da nacionalidade comum das partes. A busca dos elementos subsidiários, no entanto, só seria admissível, segundo a proposta do grupo de trabalho, se a aplicação da regra geral (residência habitual do credor) implicasse na impossibilidade de se deferir alimentos ao credor ${ }^{464}$. Na última reunião de 2006, os membros do grupo de trabalho procuraram adequar suas propostas às decisões tomadas na comissão especial de junho anterior. Os resultados foram encaminhados aos Estados membros da Organização, bem como aos Estados não membros interessados, mormente os Estados parte na convenção de Nova York de 1956. A comissão especial voltou a se reunir em maio de 2007, tendo-se projetado, inicialmente, a Sessão Diplomática que assinaria o texto da nova convenção de alimentos para setembro ou outubro de 2007. A XXI Sessão Diplomática, no entanto, transcorreu entre 5 e 23 de

${ }^{461}$ BORRÁS; GONZÁLEZ BEILFUSS. Conferencia de la Haya..., cit., p. 583-584.

${ }^{462}$ A delegação brasileira esteve composta pelos Professores João Grandino Rodas e Nadia de Araujo, como delegados do Ministério da Justiça.

${ }^{463}$ Representando o Brasil, tem assento no grupo de trabalho a Professora Nadia de Araujo, da Pontifícia Universidade Católica do Rio de Janeiro.

${ }^{464}$ Ver: BONOMI, Andrea. Rapport du groupe de travail sur la loi applicable. Doc. Prél. $\mathrm{n}^{\circ} 22$ fornecido pela Conferência da Haia de Direito Internacional Privado e publicado em: http://www.hcch.net/upload/wop/maint_pd22f.pdf Último acesso em 23.09.2008. 
novembro de 2007, tendo frutificado na nova convenção da Haia sobre a cobrança internacional de alimentos destinados às crianças e outros membros da família, além de um protocolo adicional sobre lei aplicável às obrigações alimentícias. Estiveram presentes à Sessão Diplomática sessenta e oito Estados, entre membros e convidados. Os Estados Unidos da América assinaram a convenção naquela oportunidade, aos 23 de novembro de 2007, ao passo que o protocolo adicional permanece sem assinatura.

Durante o processo de negociação foi inegável a intenção da Conferência no sentido de promover a aprovação de uma ampla e bem estruturada convenção, nos moldes das convenções de 1993 sobre adoção e 1996 sobre proteção de crianças, que tratasse, à luz das anteriores, tanto de distribuição de competência, lei aplicável, reconhecimento e execução de decisões, quanto de cooperação judiciária internacional. No entanto, influxos políticos próprios ao processo de negociação tornaram necessário o desmembramento dos objetos da convenção projetada. Não se valeu, entretanto, da estrutura seguida nas décadas de cinqüenta e setenta. Optou-se pela assinatura de uma convenção sobre reconhecimento e execução de decisões e cooperação entre os Estados membros e de um protocolo adicional sobre lei aplicável em matéria de alimentos. Será, de qualquer forma, instrumento convencional de grande valia para regular e operacionalizar as decisões relativas a prestações alimentícias, mormente em benefício de crianças que, afastadas do cotidiano convívio de um de seus genitores, permanecem titulares do direito de serem por eles sustentados, independentemente do fato de permanecerem estes casados, separados de fato, separados judicialmente, divorciados ou mesmo se nunca chegaram a constituir uma família, já que a convenção estabelece sua aplicabilidade a todas as crianças, até os 21 anos, independentemente da situação familiar vivenciada por seus pais. Admite, no entanto, a possibilidade dos Estados reservarem a aplicação da convenção aos menores de 18 anos (art. 2, 2 c/c art. 62). Trata-se de reserva que se faz baseada na reciprocidade, contrariamente ao que acontece com todas as demais reservas admitidas na convenção (art. $62,4)$. 


\title{
A COMPARAÇÃO ENTRE OS SISTEMAS E A INDICAÇÃO DE UM CAMINHO A SEGUIR
}

\begin{abstract}
SUMÁRIO: 1. A harmonização internacional dos institutos jurídicos ou os reflexos da ratificação das convenções internacionais no sistema jurídico material - 2. A escolha da lei aplicável ou os reflexos da ratificação das convenções internacionais no sistema de direito internacional privado - 3. A execução das decisões internacionais ou os reflexos da ratificação das convenções internacionais no sistema processual - 4. A cooperação internacional ou os reflexos da ratificação das convenções internacionais na organização do Estado.
\end{abstract}

\section{A HARMONIZAÇÃO INTERNACIONAL DOS INSTITUTOS JURÍDICOS OU OS REFLEXOS DA RATIFICAÇÃO DAS CONVENÇÕES INTERNACIONAIS NO SISTEMA JURÍDICO MATERIAL}

\section{Como afirma Jacob Dolinger,}

"no campo do direito, principalmente do direito internacional, a primeira reflexão que pode ocorrer sobre universalismo, globalização, é o fenômeno do direito uniforme, que é bem-vindo, benéfico, meritório, enquanto espontâneo, ou seja, quando se dá a coincidência de dois ou mais ordenamentos jurídicos, seja natural, e casualmente, seja porque têm a mesma origem, seja porque sofreram influências idênticas, ou ainda quando um país adota, por livre e espontânea vontade, um ordenamento jurídico de outro povo. (...). Excetuadas as referidas hipóteses de direito uniforme espontâneo, o direito positivo de diferentes povos é diversificado e esta diversidade é natural e necessária. Como escreve Pasquale Fiore natural a diversidade porque a legislação de cada Estado deve constituir o reflexo exato das necessidades especiais de cada povo, de acordo com o estado atual de sua cultura e o nível de sua civilização. E necessária porque a vida do direito positivo depende de seu progresso, de sua evolução, e esta permanente variação contribui para a heterogeneidade das diferentes legislações. Isto significa que sistemas jurídicos 
com a mesma origem, criados pela mesma fonte, vão se diversificando à medida que evoluem de acordo com as necessidades e influências de seu meio ambiente" 465 .

O campo das relações familiares reflete bem a realidade relativa às necessidades especiais de cada povo, conforme sua cultura e seu estágio de civilização. Com efeito, trata-se do ramo do direito privado em que a formação de um direito uniforme espontâneo é mais difícil justamente porque tais relações deixam-se permear, necessariamente, pelos valores sociais. Assim, tratando-se de seara em que a diversidade se faz presente e os valores devem falar mais alto na defesa da identidade de cada povo, pode-se intuir a dificuldade de se alcançar certa uniformização provocada, em certa medida até artificial, obtenível por meio da inclusão de disposições materiais sobre tais aspectos em tratados e convenções internacionais que se venha a negociar e assinar. Deve-se convir, ademais, que tais formas de harmonização das disposições materiais - natural e artificial - podem ser melhor alcançadas no campo do direito das obrigações ${ }^{466}$, uma vez que, como salienta Antunes Varela, trata-se do campo do direito privado com menores propensões a avanços e onde há maior proximidade entre as diversas legislações ${ }^{467}$.

No que tange ao objeto de estudo desse trabalho, em que pese a existência de uma ou outra norma, nas convenções internacionais analisadas, que fujam aos objetos do direito internacional privado regulados (conflito de leis e conflito de jurisdições), força é convir que tais normas nem de longe desempenham o papel de normas materialmente uniformes, nem sequer de normas de direito internacional privado materialmente orientadas. Nas vezes em que tais normas materiais foram incluídas nas convenções, o intuito implícito do legislador internacional parece ter sido o de garantir alguma uniformidade de qualificação para as questões que estariam e para as que não estariam abarcadas em sua regulamentação, evitando que decisões díspares pudessem ser tomadas entre os Estados que viessem a ratificar tais convenções. Disparidade não no que se refere ao resultado final da decisão, dependente por óbvio da lei a ser afinal aplicada, mas, sim, uma disparidade indesejável acerca da qualificação a ser dada a cada um dos institutos jurídicos considerados. Com efeito, se só tivesse sido feita referência ao instituto, não se teria qualquer garantia acerca de sua uniforme qualificação inclusive no que concerne à

\footnotetext{
${ }^{465}$ DOLINGER. Da dignidade..., cit., p. 120.

${ }^{466}$ DOLINGER. A evolução do direito..., cit., p. 340.

${ }^{467}$ VARELA, J. Antunes. Das obrigações em geral. v. I. 10. ed. Coimbra: Almedina, 2000.
} 
pertinência temática - ou não - da questão aos termos da convenção. Atento para a tendência de que a qualificação se faça segundo a lex fori e ciente de que a ratificação das convenções estabelece a integração de suas disposições aos diversos sistemas jurídicos nacionais, o legislador internacional estabeleceu critérios uniformes para se proceder à qualificação dos institutos.

Saliente-se, ainda e por fim que o intuito de tais convenções em momento algum foi o de alterar os valores de regência dos Estados interessados em se vincular a suas disposições. Nem sequer o de readequá-los ou moldá-los. Ademais, reconheça-se, tal papel parece ter sido bem desempenhado pela convenção de 1989 sobre os direitos da criança que deve, não obstante, ser interpretada de forma a se garantir o reconhecimento de certo relativismo cultural entre seus Estados parte ${ }^{468}$.

\section{A ESCOLHA DA LEI APLICÁVEL OU OS REFLEXOS DA RATIFICAÇÃO DAS CONVENÇÕES INTERNACIONAIS NO SISTEMA DE DIREITO INTERNACIONAL PRIVADO}

No que concerne aos sistemas nacional e convencional de determinação da lei aplicável à guarda, ao direito de visita, aos alimentos, à administração dos bens dos filhos menores e ao exercício do poder familiar, pode-se constatar inúmeras diferenças entre as determinação da lei a aplicar.

De maneira geral, pode-se perceber que o sistema de direito internacional privado brasileiro é estanque e estabelece de forma peremptória a aplicação de uma lei, ademais construída pelo intérprete já com a intenção de garantir a aplicação daquela lei que pareceu a mais próxima para a regulação da questão. No entanto, é de se convir que a construção de normas com elementos de conexão múltiplos e/ou subsidiários pode permitir maior justiça na decisão a ser tomada, uma vez que se estabeleça, dentre as diversas leis conectadas, aquela que mais facilmente pode garantir que o melhor interesse da criança seja observado.

\footnotetext{
${ }^{468}$ Todavia, se o argumento do relativismo cultural pode ser sopesado em algumas situações, essa é uma verdade que se impõe tão-só naquilo que concerne ao enriquecimento de todo o sistema de direito humanos com tendência universal. Com efeito, nenhuma denegação de direitos humanos pode ser admitida com base nesse argumento, mas é possível e até recomendável que o sistema existente enriqueça-se com as experiências éticas e culturais de outros povos e outras nações, os quais não tinham direito de voz à época da elaboração das declarações de direitos e de alguns tratados internacionais.
} 
A fim de melhor visualização da lei a ser aplicada segundo as determinações de cada um dos sistemas, apresenta-se a tabela comparativa, elaborada segundo a metodologia própria ao direito comparado, para análise:

\section{Lei aplicável}

\section{Direito internacional privado brasileiro}

Atribuição da guarda

(sistema e guardião)

\section{Direito internacional privado convencional}

- No caso de acordo ou guarda atribuída ipso facto:

lei da residência habitual da criança

- No caso de decisão judicial ou administrativa:

lex fori (competência primordial: lei da residência habitual da criança; competência subsidiária: Estado da nacionalidade da criança; da situação dos bens; do foro competente para decidir a desunião de seus pais) ou outra lei considerada mais estreita pelo juiz

\section{Direito de visita}

(local de exercício, extensão lei que regulou a guarda idem atribuição da guarda e periodicidade) 


\begin{tabular}{lll}
\hline Alimentos & $\begin{array}{c}\text { lei mais favorável ao credor } \\
\text { (criança) dentre as leis do }\end{array}$ & $\begin{array}{l}\text { Convenção de 1973: lei da } \\
\text { residência habitual da }\end{array}$ \\
para execução) & criança, da nacionalidade \\
credor & comum das partes (se a da \\
& residência habitual impedir \\
a concessão de alimentos) & ou lex fori (exceção) \\
& Convenção de 2007 \\
(protocolo adicional): lei & da residência habitual do \\
credor ou lex fori e lei da & nacionalidade comum das \\
partes (se a da residência & habitual ou o foro \\
impedirem a concessão de \\
alimentos)
\end{tabular}

Administração dos bens

dos filhos menores e

usufruto em favor dos pais lei do domicílio do

proprietário ou lei do local

da situação dos bens nihil

\section{Exercício do poder}

familiar: manutenção, suspensão ou perda

lei do domicílio da criança idem atribuição da guarda

(representação, assistência,

emancipação)

\begin{tabular}{|c|c|c|}
\hline Situações emergenciais & $\begin{array}{c}\text { lei do local em que a criança } \\
\text { se encontrar (lex fori) }\end{array}$ & $\begin{array}{c}\text { lei do local em que a criança } \\
\text { se encontrar (lex fori) }\end{array}$ \\
\hline
\end{tabular}

Por tudo quanto já ficou assentado nessa tese acerca da necessidade de maior flexibilidade do sistema de direito internacional privado na determinação do direito a aplicar, defende-se os critérios da normativa internacional como o mais coerente para os fins que a disciplina visa alcançar. 


\section{A EXECUÇÃO DAS DECISÕES INTERNACIONAIS OU OS REFLEXOS DA RATIFICAÇÃO DAS CONVENÇÕES INTERNACIONAIS NO SISTEMA PROCESSUAL}

Para Erik Jayme, as característica do mundo globalizado expressas na velocidade e na ubiqüidade atingiram em cheio o sistema de direito internacional privado e caracterizam as medidas e os procedimentos relativos à execução de julgados estrangeiros, sempre com a intenção de favorecer a "livre circulação das decisões", destituindo a pessoa humana, algumas vezes, dos mecanismos clássicos de proteção ${ }^{469}$. Com efeito, a necessidade de provimentos jurisdicionais rápidos e eficazes, capazes de fazer frente aos problemas socialmente verificados é uma característica da sociedade internacional que não se pode negligenciar e que não se coaduna com os clássicos sistemas de reconhecimento e execução de julgados que se devam executar no exterior.

A clássica figura da homologação de sentença estrangeira para sua execução no foro brasileiro, ou vice-versa, pode representar, por sua morosidade e formalismo, o perecimento efetivo dos interesses que se visava tutelar judicialmente. Ademais, o sistema desenhado em âmbito internacional, ao estabelecer prazos mais ou menos exíguos para que se configure uma presumida ambientação cultural da criança ou do adolescente ao espaço em que se encontra exigia a construção de verdadeira cooperação judiciária entre os Estados parte, a fim de permitir celeridade processual que não descurasse da segurança e não representasse flanco perigoso para a soberania do Estado. Assim é que o sistema de reconhecimento imediato das decisões estrangeiras lançadas pelo sistema administrativo ou judicial dos demais Estados parte aparece como essencial para o alcance de tais desideratos. Por outro lado, baseando-se na necessária reciprocidade imanente ao sistema convencional, o sistema interno conserva certa previsibilidade e permite a manutenção de certa segurança jurídica, privilegiando a efetividade das medidas judiciais havidas internacionalmente em matéria de guarda, direito de visitas e subtração ilícita de crianças.

E é nesse esquema de efetividade processual que se inserem as Autoridades Centrais previstas nas convenções internacionais sobre cooperação judiciária internacional para o

\footnotetext{
469 JAYME, Erik. Le droit international privé du nouveau millénaire: la protection de la personne humaine face à la globalisation. Recueil des Cours, Hague/Boston/London, v. 282, p. 9-40, 2000, p. 21.
} 
processamento de pedidos de guarda, visitas etc. e sua posterior execução imediata em outro Estado parte, no bojo do sistema convencional.

\section{A COOPERAÇÃO INTERNACIONAL OU OS REFLEXOS DA RATIFICAÇÃO DAS CONVENÇÕES INTERNACIONAIS NA ORGANIZAÇÃO DO ESTADO}

Por fim, deve-se ressaltar que o sistema de proteção das crianças em suas relações privadas tal qual desenhado no plano internacional apresenta-se coeso e coerente. A previsão da indicação de uma Autoridade Central que deva se desincumbir do gerenciamento do sistema de cooperação internacional em matéria judicial e administrativa relativa às decisões relativas a guarda e direito/dever de visitação representa a manutenção de um esquema de funcionamento testado na implantação das convenções de 1980 e 1993 e que tem garantido o bom funcionamento de tais convenções.

Por questão de coerência, dada a interdependência existente entre a atribuição da guarda, o direito de visitação e a retenção ou subtração ilícita de crianças, dever-se-ia indicar como Autoridade Central brasileira para o gerenciamento de tal sistema de cooperação internacional o mesmo órgão que hoje desempenha tais atividades no âmbito das citadas convenções já ratificadas pelo país. Trata-se, inclusive, de medida de racionalidade administrativa necessária para o bom andamento do sistema evitando decisões que gerem perplexidade por incoerência. 


\section{CONCLUSÕES}

1. A regulamentação legal que o sistema brasileiro empresta às relações familiares apresenta-se voltada a perspectiva eudemonista, em que o grupo familiar passa a ser encarado como o locus privilegiado para a realização pessoal de cada um dos indivíduos que a compõem, o que se faz em razão de um desiderato comum que se consubstancia na funcionalidade que tal família passa a exercer. A família passa a ser, então, um instrumento de realização de cada indivíduo em particular. Nesse sentido, já não é mais o indivíduo que existe em função e para a família, mas é a família que passa a existir em função e para a realização pessoal dos indivíduos que a compõem.

Tal realidade, facilmente verificável quando as relações são travadas por dois membros do grupamento familiar dotados de plena capacidade de exercício e em pleno gozo de seus direitos, espraia-se - também e não sem razão - para o conjunto de relações familiares entre pais e filhos. É nesse sentido que se afirma que as crianças não devem mais representar o objeto de desejo de seus pais (desejo de ter um filho ou de manter o filho em sua companhia), mas, sim, o de serem, antes de mais, a finalidade da atuação dos pais na condução da vida familiar. Juridicamente incapazes, as crianças devem gozar de proteção a ser desempenhada por seus genitores. Assim, a atuação dos pais deve se pautar pela consciência da existência de seres que deles ainda dependem. Nesse sentido, o eudemonismo próprio à nova realidade familiar se expressa para proceder à necessária separação entre os interesses de uns e outros, mas o Estado e seu sistema jurídico intervêem para recordar e reafirmar, sempre e ainda, que o dever familiar deverá ser exercido para a consecução dos interesses dos incapazes, enquanto etapa de seu desenvolvimento biofísico e psíquico. Tal realidade, acompanhada pelo sistema jurídico e nele expressa, reflete a adesão do Estado à consciência internacionalmente forjada desde que os direitos da criança passaram a ser reconhecidos e efetivamente garantidos no 
cenário internacional. Nesses termos, tem-se que a normativa brasileira acerca do direito de família no que concerne às relações entre pais e filhos e também a normativa acerca dos direitos da infância e da juventude demonstram adesão do Estado brasileiro a uma ordem de valores internacionalmente arquitetada em prol dos jovens e das crianças. Materialmente, então, o sistema jurídico brasileiro insere-se no grupo dos Estados que se esforça em cumprir as obrigações internacionalmente assumidas nessa seara (reconhecidas suas deficiências político-administrativas - por vezes mais numerosas do que o desejável que impedem ou retardam em demasia tal efetivação).

Assim, a atual regulamentação material forjada para temas de interesse das crianças e dos adolescentes que assistem - passivamente - ao desfazimento da cumplicidade entre seus genitores havida é bastante pertinente aos novos valores sociais, muito embora se possa aperfeiçoar o sistema. Nesse sentido, o direito comparado pode exercer interessante papel. Com efeito, a comparação entre nosso sistema material e os sistemas materiais estrangeiros acerca do assunto - que, de resto, escapa aos limites dessa tese - pode representar interessante fonte para o aperfeiçoamento de nosso sistema. Referido desfazimento de vínculos de cumplicidade acaba por desembocar na separação dos membros da família com a necessidade de se atribuir a guarda dos filhos a um ou a ambos os genitores (de forma alternada ou compartilhada), de se regulamentar o acesso do não guardião aos filhos, de se estabelecer a forma de divisão do custeio da prole, a administração dos bens dos filhos menores, dentre outros tantos e relevantes aspectos. Mormente quando essa tendência se faz verificar em sede de relações jurídicas estrangeiras, ou seja, de relações em que os elementos fáticos da situação a ser regulamentada judicialmente encontram-se afetos ou se reportam a diversos ordenamentos estrangeiros. Não parece ser o caso de se fazerem, no âmbito dessas conclusões, quaisquer reminiscências ao método do direito internacional privado. Apenas gostaria de chamar atenção para a possibilidade de que se extraiam desses casos plurilocalizados os elementos de direito comparado que a pouco se fez referência como fonte de possível avanço para a regulamentação material de tais temas. Com efeito, é da aplicação do método próprio do direito internacional privado que se poderão colher elementos comparativos relevantes para o aperfeiçoamento do sistema. No entanto, saliente-se, o recurso a tal método depende da existência efetiva de casos que o invoquem, ou seja, de casos em que a separação de vida e esforços dos pais gere a dúvida acerca de qual sistema material aplicar para a regulamentação das questões daí decorrentes. E assim, à guisa de justificativa para a 
escolha do tema, cumpre salientar que a questão, tormentosa e de difícil solução no mais simples dos casos de separação dos pais das crianças envolvidas, é muitas vezes decidida no bojo de relações em que os elementos estrangeiros se fazem presentes. Daí a relevância de se proceder à necessária reflexão sobre os princípios e valores em jogo quando entram em choque dois ou mais sistemas jurídicos que podem se reportar - ou não - àquele conjunto de valores estabelecido no cenário internacional e que presidiu a elaboração das normas sobre as relações entre pais e filhos em nosso país.

2. Pode-se concluir, em primeiro lugar, haver flagrante dissonância entre a regulamentação material estabelecida em nosso sistema jurídico para o tema da pesquisa e a regulamentação própria ao direito internacional privado, ou seja, a construção da norma indireta capaz de levar o intérprete ao sistema jurídico - nacional ou estrangeiro - a ser aplicado para a efetiva atribuição da guarda e para o desenho de suas conseqüências mais próximas. Tal dissonância, no entanto, merece melhor explicação. Um primeiro lançar de olhos sobre a questão poderia levar à conclusão de ser tal disparidade logicamente irrelevante e até impertinente. Com efeito, a partir do momento em que se comparam dois modos diferentes de se encarar a questão - uma material, outra indireta -, com objetivos distantes um do outro - resolver o litígio e indicar a fonte de resolução do litígio - poderse-ia acusar a conclusão de ausência de cientificidade. No entanto, parece-me, a conclusão de haver flagrante dissonância entre tais normas pode ser justificada com base nos valores que permeiam uma e outra forma de se regulamentar o mesmo problema. A indagação, então, que presidiu a reflexão que se procurou construir foi a seguinte: até que ponto as normas de direito internacional privado que buscam estabelecer a lei aplicável à atribuição da guarda, ao direito-dever de visitação, aos alimentos, à administração dos bens dos filhos menores, dentre outras questões conexas não deveriam ser, também, permeadas pelos mesmos valores internacionalmente edificados e que serviram de sustentação para a regulamentação material de tais temas em nosso ordenamento jurídico.

É que se o direito internacional privado brasileiro, enquanto ramo do direito interno, compõe o mesmo ordenamento em que inseridas as normas materiais sobre a questão, por que não se verificam identidades de propósitos entre o legislador civil e o legislador do direito internacional privado? Por que um dos legisladores busca refletir valores socialmente adequados enquanto o outro se mantém preso a modo de pensamento asséptico em que os valores parecem antes atrapalhar sua atuação do que lhe servir de guia? Assim é 
que se procurou empreender estudo teórico que pudesse servir de pano de fundo para a defesa de linha de raciocínio que procurasse emprestar às normas do direito internacional privado brasileiro e àquelas elaboradas pelo legislador internacional e estampadas em convenções sobre a determinação da lei aplicável, certa permeabilidade a valores maiores reconhecidos pela sociedade internacional. Defendeu-se, por isso, que o processo para a escolha da lei aplicável a tais temas seja regido pelos valores eudemonistas, capazes de reconhecer certa funcionalidade à família e a seus membros, estabelecendo como norte necessário para o problema a tentativa de se aplicar a lei que melhor satisfaça o interesse da criança, por ser aquela que maior proximidade guarda com os valores em jogo para a regulamentação da questão. Por óbvio não se defendeu a identificação material entre os sistemas como fator de determinação da lei a aplicar. A defesa recaiu sobre a necessidade de que as normas de direito internacional privado fossem construídas baseadas em tais valores. Assim, a conclusão para este tópico é que a lei a ser aplicada para a resolução de questões atinentes a guarda, direito de visitação, alimentos, administração dos bens dos filhos incapazes e outras medidas quaisquer de proteção deve ser a lei material que melhor satisfaça os interesses da criança, sujeito de direitos, e não a de seus genitores que tomam, no mais das vezes, como objeto de seus próprios desejos.

3. Partindo-se de tal conclusão, procurou-se proceder à construção das normas brasileiras de direito internacional privado sobre tais temas. Para tanto, partindo-se da legislação interna em vigor, procurou-se indagar acerca da lei a ser aplicada para a resolução material da atribuição da guarda, do direito de visitas, dos alimentos, da administração dos bens dos filhos menores fazendo-se o necessário uso dos posicionamentos doutrinários acerca de tais assuntos, uma vez que se pode constatar desde logo a insuficiência das disposições legais atualmente em vigor para fazer frente à complexidade de tais temas. Até porque, como se concluiu também desde cedo, tal regulamentação legal, construída para outra sociedade - patriarcal -, não consegue se amoldar à sociedade igualitária, eudemonista e funcional hoje vivenciada. Em seguida, seguindo o mesmo raciocínio, procedeu-se à análise das convenções internacionais sobre os pontos que constituem o objeto dessa tese.

Tal análise procurou ser, até certa medida, neutra em ambas as normativas. Isso porque pareceu importante procurar perceber se havia em um ou em outro sistema um quadro regulamentador que pudesse, desde o início, se amoldar aos valores que pareciam 
importantes privilegiar e fomentar na construção das normas indiretas. Além disso, o intuito principal em tal tentativa de se manter certa neutralidade científica era o de estabelecer um patamar mínimo a partir do qual se poderia, por recurso interpretativo, proceder a eventual desvio desde o padrão mínimo para que se pudesse chegar aos valores que, segundo já se havia concluído, deveriam presidir o processo de escolha da lei aplicável. Por fim, com base em tais desenhos tendenciosamente neutros, procurou-se proceder à comparação de ambos o sistemas, donde se pode extrair as principais conclusões acerca dessa tese, expressas em seu quinto capítulo.

4. As convenções internacionais sobre o objeto de estudo dessa tese não tencionaram estabelecer disposições que pudessem influir materialmente nos diversos sistemas jurídicos dos Estados que viessem a ratificá-las. Pelo contrário, pode-se concluir que a elaboração de normas materiais em tais convenções teve o intuito único de gerar um sistema uniforme de qualificação que permitisse a utilização, por todos os Estados que incorporassem suas disposições a seus próprios sistemas, de uma linguagem comum para fins de qualificação. Conclui-se, assim, que o legislador internacional andou bem em não tentar imiscuir-se no sistema material de direito de família dos Estados parte, pois isso poderia gerar posicionamentos refratários indesejáveis na medida em que esse ramo do direito privado é bastante permeável à conformação ético-valorativa do povo a que se destina e qualquer tentativa de harmonização artificial poderia gerar o malogro do sistema convencional.

5. Acredita-se que esta tese tenha contribuído originalmente para o pensamento jurídico ao elaborar construção sistemática acerca da lei a ser aplicada aos institutos da guarda, da visitação, dos alimentos, da administração dos bens dos filhos menores e do exercício do poder familiar, integrando-os como elos de uma cadeia que visa resguardar a criança em suas relações familiares. Assim, ao se construir a norma de direito internacional privado vigente no sistema brasileiro, buscou-se privilegiar a lei que pareceu ser a mais benéfica e mais apta a resguardar o melhor interesse da criança, sempre dentro dos limites normativos estabelecidos pela Lei de introdução ao código civil de 1942. Pode-se, então, concluir o seguinte:

5.1. Atribuição da guarda: lei do domicílio da criança;

5.2. Direito de visita: lei que regulou a guarda;

5.3. Alimentos: lei mais favorável ao credor; 
5.4. Administração dos bens dos filhos: em razão do escopo que o sistema visa atingir ao instituir o dever de administração dos bens dos filhos pelos pais, procurou-se defender a aplicação da lei do domicílio do proprietário, muito embora haja quem defenda a aplicação da lei da situação dos bens;

5.5. Exercício do poder familiar: lei do domicílio da criança;

5.6. Situações emergenciais: lei do local em que a criança se encontrar (lex fori).

No entanto, tal construção, científica e sistemática não pareceu ser a que melhor servia aos desígnios do sistema material, influenciado pela normativa internacional.

6. Bem por isso, após a descrição das normas das convenções sobre tais temas, pode-se concluir que o sistema internacional estabelece mecanismo de determinação da lei aplicável mais aberto, garantindo ao magistrado ou à autoridade administrativa margem de manobra com o escopo de beneficiar os interesses da criança justamente porque tal sistema estabelece critérios alternativos e/ou subsidiários mais adequados à construção teórica que esta tese propôs quanto as relações privadas havidas entre pais e filhos.

\subsection{Atribuição da guarda:}

6.1.1. convencionada pelas partes ou decorrente da lei, sem intervenção judicial: lei da residência habitual da criança;

6.1.2. decorrente de decisão judicial ou administrativa: lex fori (competência primordial: lei da residência habitual da criança; competência subsidiária: Estado da nacionalidade da criança; da situação dos bens; do foro competente para decidir a desunião de seus pais) ou outra lei considerada mais estreita pelo juiz

\subsection{Direito de visita:}

6.2.1. convencionada pelas partes ou decorrente da lei, sem intervenção judicial: lei da residência habitual da criança;

6.2.2. decorrente de decisão judicial ou administrativa: lex fori (competência primordial: lei da residência habitual da criança; competência subsidiária: Estado da nacionalidade da criança; da situação dos bens; do foro competente para decidir a desunião de seus pais) ou outra lei considerada mais estreita pelo juiz

6.3. Alimentos: Convenção de 1973: lei da residência habitual da criança, da nacionalidade comum das partes (se a da residência habitual impedir a concessão de 
alimentos) ou lex fori (exceção); Convenção de 2007 (protocolo adicional): lei da residência habitual do credor ou lex fori e lei da nacionalidade comum das partes (se a da residência habitual ou o foro impedirem a concessão de alimentos)

6.4. Administração dos bens dos filhos: não há disposição nas convenções analisadas;

6.5. Exercício do poder familiar:

6.5.1. convencionada pelas partes ou decorrente da lei, sem intervenção judicial: lei da residência habitual da criança;

6.5.2. decorrente de decisão judicial ou administrativa: lex fori (competência primordial: lei da residência habitual da criança; competência subsidiária: Estado da nacionalidade da criança; da situação dos bens; do foro competente para decidir a desunião de seus pais) ou outra lei considerada mais estreita pelo juiz

6.6. Situações emergenciais: lei do local em que a criança se encontrar (lex fori).

7. No que concerne à comparação dos sistemas clássico e convencional tendentes a emprestar efetividade às decisões estrangeiras no foro de um Estado parte nas convenções, pode-se concluir que o sistema internacionalmente estabelecido apresenta vantagens relativas à celeridade e à conservação dos direitos que se visa proteger e resguardar ao dispensar a necessidade de homologação de sentenças estrangeiras, concedendo-se espécie de exequatur ipso facto. Tal sistema, vigente no Brasil para decisões havidas acerca de subtração internacional de crianças e de adoção internacional reaparece na convenção de 1996, merecendo a atenção do legislador nacional para a conveniência e oportunidade de sua ratificação.

8. Por fim, percebe-se que o sistema de proteção internacional das crianças em suas relações privadas, coeso e coerente, não implicará, caso se venha a ratificar a convenção de 1996, completando-se tal sistema de proteção, quaisquer ônus adicionais ao Estado brasileiro e sua máquina burocrática. Isso porque, valendo-se de esquemas de funcionamento testados na implantação das convenções de 1980 e 1993, dever-se-ia indicar como Autoridade Central brasileira para o gerenciamento do sistema de cooperação internacional o mesmo órgão que desempenha tais atividades no âmbito das citadas convenções já ratificadas pelo país. Trata-se, inclusive, de medida de coerência e racionalidade administrativas necessária para o bom andamento do sistema evitando decisões que gerem perplexidade por incoerência. 


\section{B I B L I O G R A F I A}

AGAllOPOULOU, Pénélope. L'enfant et la justice selon le droit hellénique. Revue Hellénique de Droit Internacional, Atenas, v. 48, p. 267-276, 1995.

AGUILLAR BENÍTEZ DE LUGO, Mariano. La familia en los convenios de la Conferencia de la Haya de Derecho Internacional Privado. Revista Española de Derecho Internacional, Madrid, v. 45, n. 1, p. 7-37, 1993.

ALTAVA LAVALL, Manuel Guillermo (coord.). Lecciones de derecho comparado. Castelló de la Plana: Publicacions de la Universitat Jaume I, 2003.

ALVAREZ GONZÁLEZ, Santiago. Cláusulas de compatibilidad en los convenios de la Conferencia de la Haya de DIPR. Revista Española de Derecho Internacional, Madrid, v. 45, n. 1, p. 39-62, 1993.

. Nuevas "medidas relativas al retorno de menores en supuestos de sustracción internacional" en la ley de enjuiciamiento civil. Revista Española de Derecho Internacional. Madrid, v. 48, n. 1, p. 504-507, 1996.

AMARAL, Francisco. Direito Civil - Introdução. 3. ed. Rio de Janeiro/São Paulo: Renovar, 2000.

AMARAL JUNIOR, Alberto do. Entre ordem e desordem: o direito internacional em face da multiplicidade de culturas. In: BAPTISTA, Luiz Olavo; FONSECA, José Roberto Franco da. $O$ direito internacional no terceiro milênio: estudos em homenagem a 
Vicente Marotta Rangel. São Paulo: LTr, p. 152-165, 1998.

ANCEL, Marc. Utilidade e métodos do Direito Comparado [Utilité et méthodes du droit comparé]. Trad. Sérgio José Porto. Porto Alegre: Sérgio Antonio Fabris editor, 1980.

ANZILOTTI, Dionísio. Corsi di diritto internazionale privato e processuale. Padova: CEDAM, 1996.

ARAUJO, Nadia de. Direito internacional privado: teoria e prática brasileira. 4. ed. Rio de Janeiro/São Paulo: Renovar, 2008.

ARENAS GARCÍA, Rafael. Problemas derivados de la reagrupación familiar. Anuário Español de Derecho Internacional Privado, Madrid, n. 5, p. 269-307, 2005.

ARMINJON, Pierre. L'objet et la méthode du droit international privé. Recueil des Cours, Paris: Librairie Hachette, v. 21, p. 429-512, 1928.

AUDINET, E. Les conflits de lois en matière de mariage et de divorce. Recueil des Cours, Paris: Librairie Hachette, v. 11, p. 171-252, 1926.

AZEVEDO, Antonio Junqueira de. Negócio Jurídico: Existência validade e eficácia. 3. ed. São Paulo: Saraiva, 2000.

BAINHAM, Andrew. Men and women behaving badly: is fault dead in English family law? Oxford Journal of Legal Studies. Oxford, v. 21, n. 2, p. 219-238, 2001.

BALFOUR, Ian L. S.; CRAWFORD, Elizabeth B. The Hague Convention on International Child Abduction. Recent Scottish Cases. Scottish Law \& Practice Quarterly, v. 1, n. 5, p. 411-423, Oct 1996.

BALLARINO, Tito. Diritto internazionale privato. 2. ed. Padova: Cedam, 1996.

BAPTISTA MACHADO, João. Lições de direito internacional privado. 3. ed. (reimp.). Coimbra: Almedina, 2006.

BARNICH, Laurent. Les actes juridiques en droit international privé. Essai de Méthode. Bruxelles: Bruylant, 2001.

BARONTINI, Giovanni. Dissolução do vínculo conjugal no âmbito internacional. Dissertação de mestrado apresentada à Faculdade de Direito da Universidade de São Paulo, sob orientação do Professor José Carlos de Magalhães, 1998. 
BARTIN, Etienne-Adolphe. La doctrine des qualifications et ses rapports avec le caractère national des règles du conflit des lois. Recueil des Cours, Paris: Librairie du Recueil Sirey, v. 31, p. 562-621, 1930.

BATIFFOL, Henri. Aspects philosophiques du droit international privé. Paris: Dalloz, 2002 (fac-símile da edição de 1956).

. La douzième session de la Conférence de La Haye de Droit International Privé. Revue Critique de Droit International Privé, Paris, v. 62, p. 243-273, 1973.

La quatorzième session de la Conférence de La Haye de Droit International Privé. Revue Critique de Droit International Privé, Paris, v. 70, n. 2, p. 231-245, 1981. - Les tendances doctrinales actuelles en droit international privé. Recueil des Cours, Paris: Librairie du Recueil Sirey, v. 72, p. 1-66, 1948.

BAUDOUIN, Jean-Marie. La protection du mineur étranger par le juge des enfants. Revue Critique de Droit International Privé, Paris, v. 83, n. 3, p. 483-503, 1994.

BAUMAN, Zygmunt. Amor líquido: sobre a fragilidade dos laços humanos [Liquid love (on the frailty of human bonds)]. Trad.Carlos Alberto Medeiros. Rio de Janeiro: Jorge Zahar, 2004.

BAVA BUSSALINO, Pablo. Los hijos ante la disolución conyugal: el divorcio o la enfermedad del amor. Revista del Colegio de Abogados de La Plata, La Plata, v. 38, n. 59, p. 61-69, 1998.

BECK-PECCOZ, Roberto Aluffi. La leggi del diritto di famiglia negli stati arabi del nordAfrica. Torino: Fondazione Giovanni Agnelli, 1997.

BENATTAR, Raoul. Problèmes relatifs au droit international privé de la famille dans le pays de droit personnel. Recueil des Cours, Leyde: A. W. Sijthoff, v. 121, p. 1-112, 1969.

BENTO XVI, Papa. Deus Caritas est - Carta encíclica sobre o amor cristão. (sem indicação do tradutor). São Paulo: Paulinas, 2006.

BETTSCHART, Walter; FAVRE, Xavier. Direitos de guarda e de visita de filhos de pais separados ou divorciados: a peritagem pelo psiquiatra infantil. Infância e Juventude, 
Lisboa, n. 1, p. 9-29, 1991.

BISCARETTI DI RUFFIA, Claudio. Le obligazioni alimentari nel diritto internazionale privato convenzionale. Padova: Cedam, 1989.

BONNARD, Jerome. La garde du mineur et son sentiment personnel. Revue Trimestrielle de Droit Civil, Paris, v. 90, n. 1, p. 49-67, 1991.

BONOMI, Andrea. Il regolamento comunitário sulla competenza e sul riconoscimento in materia matrimoniale e di potestà dei genitori. Rivista di Diritto Internazionale, Milano, v. 84, n. 2, p. 298-346, 2001.

La convenzione dell'Aja de 1961 sulla protezione dei minori: un riesame dopo la ratifica italiana e l'avvio dei lavori di revisione. Rivista di Diritto Internazionale Privato e Processuale, Padova, v. 31, n. 3, p. 607-656, 1995.

Rapport du groupe de travail sur la loi applicable. Doc. Prél. n. 22 fornecido pela Conferência da Haia de Direito Internacional Privado e publicado em: http://www.hcch.net/upload/wop/maint_pd22f.pdf

BORRÁS RODRÍGUEZ, Alegria. El "interes del menor" como factor de progreso y unificación del derecho internacional privado (discurs d'ingres). Revista Juridica de Catalunya, Barcelona. v. 93. n. 4. p. 915-967. 1994.

El papel de la "autoridad central": los Convenios de La Haya y España. Revista Española de Derecho Internacional, Madrid, v. 45, n. 1, p. 63-80, 1993.

BORRÁS, Alegría. Competencia judicial, reconoscimiento y ejecución de decisiones en materia matrimonial: el reglamento 1.347/2000, de 29 de mayo (Bruselas II). Revista Jurídica de Catalunya, Barcelona. v. 102. n. 2. p. 361-386. 2003.

. Conferencia de La Haya de Derecho Internacional Privado: reunión de la comisión especial sobre aplicación de los convenios en materia de alimentos (13-17 de noviembre de 1995). Revista Española de Derecho Internacional, Madrid, v. 47, n. 2 , p. 498-502, julio/diciembre, 1995.

Conferencia de la Haya de Derecho Internacional Privado: tercera reunión de la comisión especial sobre la aplicación del Convenio de la Haya de 1980 sobre sustracción internacional de menores (17 a 21 de marzo de 1997). Revista Española de 
Derecho Internacional, Madrid, v. 49, n. 1, p. 348-350, 1997.

Conferencia de la Haya de Derecho Internacional Privado: tercera reunión de la comisión especial sobre la protección de los menores y de los incapaces mayores (La Haya, 11-22 de septiembre de 1995). Revista Española de Derecho Internacional, Madrid, v. 47, n. 2, p. 493-495, 1995.

Conferencia de la Haya de Derecho Internacional Privado: segunda comisión especial para la revisión del Convenio de la Haya de 1961 sobre protección de menores (La Haya, 6-17 de febrero de 1995). Revista Española de Derecho Internacional, Madrid, v. 47, n. 1, p. 314-317, 1995.

. Les ordres plurilégislatifs dans le droit international privé actuel. Recueil des Cours, Dordrecht/Boston/Lancaster: Martinus Nijhoff Publishers, v. 249, p. 145-368, 1994.

Practica española en aplicación del Convenio de La Haya de 1980 sobre sustracción internacional de menores. In: La sustracción internacional de los menores (aspectos civiles) - II Jornadas de D.I.P. (Patronato Universitario de Toledo), p. 81-93. Separata fornecida pela Conferência da Haia de Direito Internacional Privado, s/d.

BORRÁS, Alegría; GONZÁLEZ BEILFUSS, Cristina. Conferencia de la Haya de derecho internacional privado: comisión especial sobre el cobro de alimentos con respecto a la familia. Revista Española de Derecho Internacional, Madrid, v. 55, n. 1, p. 582-585, 2003.

BORRÁS, Alegría; PÉREZ VERA, Elisa. Conferencia de la Haya de Derecho Internacional Privado: primera comisión especial para la modificación del Convenio sobre protección de menores (26 de mayo a 3 de junio de 1994). Revista Española de Derecho Internacional, Madrid, v. 46, n. 2, p. 916-919, 1994.

BOSCHI, Fábio Bauab. Direito de visita. São Paulo: Saraiva, 2005.

BOSCHIERO, Nerina. Norme di diritto internazionale privato "facoltative"? Rivista di Diritto Internazionale Privato e Processuale, Padova, v. 29, n. 3, p. 541-588, 1993.

BOXSTAEL, Jean-Louis van. L'administration de la personne et des biens des incapables. In: VERWILGHEN, Michel; VALKENNER, Roland de. Relations familiales 
internationales. Bruxelles: Bruylant, p. 191-234, 1993.

BRUCH, Carol S. Casos de rapto internacional de crianças: experiência ao abrigo da Convenção da Haia de 1980. Trad. Teresa Trigo de Sousa. Infância e Juventude, Lisboa, n. 3, p. 35-63, 1993.

. O rapto civil de crianças e os tribunais ingleses. Trad. Maria Ana do Canto e

Castro; Teresa Trigo de Sousa. Infância e Juventude, Lisboa, n. 4, p. 63-81, 1993.

BUCHER, Andreas. La famille en droit international privé. Recueil des Cours, The Hague/Boston/London: Martinus Nijhoff Publishers, v. 283, p. 9-186, 2000.

. L'enfant en droit international privé. Genève/Bâle/Munich: Helbing \& Lichtenhahn, 2003.

BUEREN, Geraldine van. The international law on the rights of the child. The Hague/Boston/London: Martinus Nijhoff Publishers, 1998.

CABRAL, Karina Melissa. A mulher e o novo Código Civil: a confirmação do princípio da isonomia. Revista de Direito Privado, São Paulo, ano 5, v. 17, p. 135-150, 2004.

CADOCHE, Sara Noemí (Dir.). Violencia familiar. Buenos Aires: Rubinzal-Culzoni Editores, 2002.

CAHALI, Yussef Said. A importância do instituto da guarda. Revista de Jurisprudência do Tribunal de Justiça do Estado de São Paulo, São Paulo, v. 25, n. 133, p. 9-18, 1991.

CALVO CARAVACA, Alfonso-Luís; CARRASCOSA GONZÁLEZ, Javier. Derecho Internacional Privado. v. 1. 5. ed. Granada: Comares, 2004. Derecho Internacional Privado. v. 2. 5. ed. Granada: Comares, 2004.

CAMBI, Eduardo. Admissibilidade excepcional e condições para a concessão da guarda aos avós da criança ou do adolescente para atender situações peculiares (exegese do art. 33, § $2^{\circ}$ do ECA). Revista de Direito Privado, São Paulo, ano 3, v. 12, p. 131-134, 2002.

CANÇADO TRINDADE, Antonio Augusto. Reflexões sobre o método comparado no direito internacional. $O$ direito internacional em um mundo em transformação. Rio de Janeiro: Renovar, p. 143-163, 2002. 
CANEZIN, Claudete Carvalho. Da guarda compartilhada em oposição à guarda unilateral. Revista Brasileira de Direito de Família, Porto Alegre, ano 6, n. 28, p. 5-25, 2005.

CANSACCHI, Giorgio. Le choix et l'adaptation de la règle étrangère dans le conflit de lois. Recueil des Cours, Leyde: A. W. Sijthoff, v. 83, p. 79-162, 1955.

CARELLA, Gabriella. La convenzione dell'Aja del 1980 sugli aspetti civili della sottrazione internazionale di minori. Rivista di Diritto Internazionale Privato $e$ Processuale, Padova, v. 30, n. 4, p. 777-794, 1994.

CASABONA, Marcial Barreto. Guarda compartilhada. São Paulo: Quartier Latin, 2006.

CASELLA, Paulo Borba. A ordem pública e a execução de cartas rogatórias no Brasil. Revista da Faculdade de Direito da Universidade de São Paulo, São Paulo. v. 98, p.563-571, 2003.

. Modalidades de harmonização, unificação e uniformização do direito: o Brasil e as convenções interamericanas de direito internacional privado. In: CASELLA, Paulo Borba; ARAUJO, Nadia. Integração jurídica interamericana: as convenções interamericanas de direito internacional privado (CIDIPs) e o direito brasileiro. São Paulo : LTr, p. 77-105, 1998.

CASSIN, René. La nouvelle conception du domicile dans le règlement des conflits de lois. Recueil des Cours, Paris: Librairie du Recueil Sirey, v. 34, p. 655-810, 1930.

CASTRO, Amilcar de. Direito internacional privado. 5. ed. atualizada por ROCHA, Osíris. Rio de Janeiro: Forense, 1997.

CASTRO, Lídia Rosalina Folgueira. Disputa de guarda e visitas: no interesse dos pais ou dos filhos? São Paulo: Casa do psicólogo, 2003.

CHALAS, Christelle. L'exercice discrétionnaire de la competénce juridictionnelle en droit internacional privé, t. I e II. Aix-en-Provence: Presses Universitaires d'Aix-Marseille, 2000.

CHESHIRE, Geoffrey Chevalier. The concept of marriage and the relations between husband and wife. Recueil des Cours, Leyde: A. W. Sijthoff, v. 108, p. 115-188, 1963.

CLIVE, Eric. The New Hague Convention on Children. Greens Family Law Bulletin, p. 35, Jan 1997. 
COELHO, Bernardo Leôncio Moura. O bloco de constitucionalidade e a proteção à criança. Revista de Informação Legislativa, Brasília, n. 123, p. 259-266, 1994.

COLLIER, Richard. Masculinity, law and the family. London and New York: Routledge, 1995.

CORNELOUP, Sabine; CORNELOUP, Vincent. Le contentieux de la coopération des autorités centrales dans le cadre des conventions de la Haye. Competénce administrative ou judiciaire? Revue Critique de Droit International Privé, Paris, v. 89, n. 4, p. 641-680, 2000.

COSCIA, Giuseppe. Condizione di reciprocità e diritto internazionale privato. Rivista di Diritto Internazionale Privato e Processuale, Padova, v. 37, n. 3, p. 557-568, 2001.

CURY, Munir (Coord.). Estatuto da criança e do adolescente comentado. Comentários jurídicos e sociais. 7. ed. São Paulo: Malheiros, 2005.

CUSTODIO, Gloria M. The discourse of discrimination: how lesbian mothers are judged in child custody disputes. Revista Jurídica de la Universidad de Puerto Rico, Rio Piedras, v. 63, n. 3, p. 531-550, 1994.

DANTAS, Ivo. Direito Constitucional Comparado. Introdução. Teoria e Metodologia. 2. ed. Rio de Janeiro: Renovar, 2006.

O direito comparado: formação histórica, métodos e técnicas de pesquisa. Anuário dos Cursos de Pós-Graduação em Direito, Recife, n. 8, p. 167-199, 1997.

DE BOER, Ted. The Hague Conference and Dutch choice of law: some criticism and a suggestion. Netherlands International Law Review, The Hague, v. 40, n. 1, p. 1-14, 1993.

Jurisdiction and enforcement in international family law: a labyrinth of European and international legislation. Netherlands International Law Review, The Hague, v. 49, n. 3, p. 307-351, 2002.

DE CESARI, Patrizia. Diritto agli alimenti del figlio naturale, convenzioni dell'Aja e ordine pubblico. Rivista di Diritto Internazionale Privato e Processuale, Padova, v. 10, n. 2, p. 238-259, 1974. 
Le nuove convenzioni dell'Aja in materia di obbligazioni alimentari. Rivista di Diritto Internazionale Privato e Processuale, Padova, v. 19, n. 1, p. 42-68, 1983.

DE SIMONE, Francesco. Lezioni di Diritto Privato Comparato. Napoli: Edizioni Scientifiche Italiane, 1997.

DELINSKI, Julie Cristine. O novo direito da filiação. São Paulo: Dialética, 1997.

DÉPREZ, Jean. Droit international privé et conflits de civilisations - aspects méthodologiques. Recueil des Cours, Dordrecht/Boston/Lancaster: Martinus Nijhoff Publishers, v. 211, p. 9-372, 1988.

DESNOYER, Christine. L'évolution de la sanction en droit de la famille. Paris: L'Harmattan, 2001.

DETHLOFF, Nina. Arguments for the unification and harmonisation of family law in Europe. In: BOELE-WOELKI, Katharina (Ed.). Perspectives for the unification and harmonisation of family law in Europe. Antwerp/Oxford/New York: Intersentia, p. 3764, 2003.

DODGE, William S. Extraterritoriality and conflict-of-laws theory: an argument for judicial unilateralism. Harvard International Law Journal, Cambridge, v. 39, n. 1, p. 101-169, 1998.

DOLINGER, Jacob. A criança no direito internacional. São Paulo/Rio de Janeiro: Renovar, 2003.

A evolução da ordem pública no direito internacional privado. Tese apresentada à Congregação da UERJ para o concurso à Cátedra de Direito Internacional Privado, 1979.

A evolução do direito internacional privado no século XX. In: DIREITO, Carlos Alberto Menezes. Estudos em homenagem ao Prof. Caio Tácito. Rio de Janeiro: Renovar, p.335-348, 1997.

A família no direito internacional privado: casamento e divórcio. São Paulo/Rio de Janeiro: Renovar, 1997.

A ordem pública internacional em seus diversos patamares. Revista dos Tribunais, São Paulo, v. 93, n. 828, p. 33-42, out. 2004. 
Contratos e obrigações no direito internacional privado. São Paulo/Rio de Janeiro: Renovar, 2007.

. Convenção interamericana sobre normas gerais de direito internacional privado. Revista da Faculdade de Direito da Universidade do Estado do Rio de Janeiro, Rio de Janeiro, n.3, p.19-46, 1995.

Da dignidade da diferença ao moderno direito internacional privado. Revista Forense, Rio de Janeiro, v. 100, n. 373, p. 113-120, maio/jun. 2004.

Direito internacional privado: parte geral. 8. ed. São Paulo/Rio de Janeiro: Renovar, 2005.

. O direito e o amor. Revista da Faculdade de Direito da Universidade do Estado do Rio de Janeiro, Rio de Janeiro, n. 2, p. 233-245, 1994.

Ordem pública mundial: ordem pública verdadeiramente internacional no direito internacional privado. Revista de Informação Legislativa, Brasília, v. 23, n. 90, p. 205232, 1986.

DOMÍNGUEZ LOZANO, Pilar. La determinación de la ley aplicable a las obligaciones de alimentos en el derecho internacional privado español. Revista Española de Derecho Internacional, Madrid, v. 41, n. 2, p. 433-485, 1989.

Las concepciones publicista y privatista del objeto del derecho internacional privado en la doctrina europea: reconstrucción histórica. Revista Española de Derecho Internacional, Madrid, v. 46, n. 1, p. 99-134, 1994.

DOSI, Gianfranco. Dall'interesse ai diritti del minori: alcune riflessioni. Il diritto di famiglia e delle persone, Milano, v. 24, n. 4, p. 1604-1627, 1995.

DUARTE, Lenita Pacheco Lemos. A guarda dos filhos na família em litígio: uma interlocução da psicanálise com o Direito. Rio de Janeiro: Lumen Juris, 2006.

DUNCAN, William. A actuação em apoio da Convenção da Haia: ponto de vista do secretariado permanente. Trad. Pedro Miguel Duarte. Infância e Juventude, Lisboa, n. 4, p. 9-34, 2001.

Children's rights, cultural diversity and private international law. In: Children's Rights and Traditional Values. Aldershot/Brookfield (USA)/Singapore/Sydney: 
Ashgate-Dartmouth, 2002.

The Hague Conference on Private International Law and its current programme of work concerning the international protection of children and other aspects of family law. Yearbook of Private International Law, The Hague/London/Boston, v. 2, p. 41-54, 2000.

DUTOIT, Bernard; MAJOROS, Ferenc. Le lacis des conflits de conventions en droit privé et leurs solutions possibles. Revue Critique de Droit International Privé, Paris, v. 73, n. 4, p. 566-596, 1984.

DYER, Adair. A Conferência da Haia completa cem anos de trabalho no campo do direito dos menores. Trad. Teresa Trigo de Sousa. Infância e Juventude, Lisboa, n. 3, p. 9-33, 1993.

A Convenção da Haia sobre os aspectos civis do rapto internacional de crianças - para uma cooperação global. Os seus sucessos e insucessos. Trad. Teresa Trigo de Sousa. Infância e Juventude, Lisboa, n. 3, p. 9-36, 1994.

Os direitos da infância no direito internacional privado. Trad. Teresa Trigo de Sousa. Infância e Juventude, Lisboa, n. 2, p. 9-37, 1992.

Protecting the right to multicultural education. Revista Española de Pedagogía, ano 49, n. 190, p. 411-418, Sep-dic 1991.

EKSTRÖM, Monika; TENREIRO, Mário. Unification of private international law in family law matters within the European Union. In: BOELE-WOELKI, Katharina (Ed.). Perspectives for the unification and harmonisation of family law in Europe. Antwerp/Oxford/New York: Intersentia, p. 185-193, 2003.

ESPINAR VICENTE, Jose Maria. Ensayos sobre teoría general del derecho internacional privado. Madrid: Civitas, 1997.

ESPINOSA CALABUIG, Rosario. La responsabilidad parental y el nuevo reglamento de "Bruselas II, bis": entre el interés del menor y la cooperación judicial interestatal. Rivista di Diritto Internazionale Privato e Processuale, Padova, v. 39, n. 3-4, p. 735$782,2003$.

EVRIGENIS, Dimitrios J. Tendances doctrinales actuelles en droit international privé. 
Recueil des Cours, Leyde: A. W. Sijthoff, v. 118, p. 313-434, 1966.

FACHIN, Rosana Amara Girardi. Dever alimentar para um novo direito de família. Rio de Janeiro: Renovar, 2005.

FALBO, Ricardo Nery. Natureza do conhecimento jurídico. Generalidade e especificidade no direito da criança e do adolescente. Porto Alegre: Sergio Antonio Fabris Editor, 2002.

FANNI, Luisella (Org.). Quale processo per la famiglia e i minori? Milano: Giuffrè, 1999.

FAUVARQUE-COSSON, Bénédicte. Libre disponibilité des droits et conflits de lois. Paris: LGDJ, 1996.

FÉRES-CARNEIRO, Terezinha; MAGALHÃES, Andrea Seixas. Conjugalidade dos pais e projeto dos filhos frente ao laço conjugal. In: FÉRES-CARNEIRO, Terezinha (org.). Família e casal: efeitos da contemporaneidade. Rio de Janeiro: PUC-Rio, 2005.

FERNANDEZ ARROYO, Diego P. Convención interamericana sobre restitución internacional de menores de 15 de julio de 1989. Revista de Informação Legislativa, Brasília, n. 111, p. 139-137, out./dez. 2000.

FERNÁNDEZ ROZAS, José Carlos. Las obligaciones alimenticias en el derecho internacional privado español. Revista Española de Derecho Internacional, Madrid, v. 37, n. 1, p. 67-108, 1985.

FERRAZ, Fernanda de Figueiredo. Separação e divórcio: doutrina e prática. São Paulo: Quartier Latin, 2005.

FERRER CORREIA, António. Lições de direito internacional privado I. Coimbra: Almedina, 2000.

. Principais interesses a considerar na resolução dos conflitos de leis. Direito internacional privado - Estudos Jurídicos III. Coimbra: Atlântida, p. 84-92, 1970.

. O método conflitual em direito internacional privado e as soluções alternativas. Revista de Direito Comparado Luso-Brasileiro, Rio de Janeiro, n. 1, p. 1-24, jul. 1982.

FIORAVANTI, Cristiana. Rapporti di famiglia e ricerca di collegamenti "complementari” o "sussidiari" nel diritto internazionale privato italiano. Rivista di Diritto Internazionale 
Privato e Processuale, Padova, v. 24, n. 4, p. 675-690, 1988.

FONGARO, Eric. La loi aplicable à la preuve en droit internacional privé. Paris: LGDJ, 2004.

FONSECA, Priscila Maria Pereira Corrêa da. Modificação da guarda de filhos. Revista do Advogado, São Paulo, n. 25, p. 76-82, maio 1988.

FOYER, Jacques. Problèmes de conflits de lois en matière de filiation. Recueil des Cours, The Hague/Boston/London: Martinus Nijhoff Publishers, v. 193, p. 9. 117, 1985.

FRAGA, Thelma. A guarda e o direito à visitação sob o prisma do afeto. Niterói: Ímpetus, 2005.

FRANCHI, Marina. Protezione dei minori e diritto internazionale privato. Milano: Giuffrè, 1997.

FRANKENSTEIN, Ernst. Tendances nouvelles du droit international privé. Recueil des Cours, Paris: Librairie du Recueil Sirey, v. 33, p. 242-350, 1930.

GANNAGÉ, Léna. La hiérarchie des normes et les méthodes du droit international privé: étude de droit international privé de la famille. Paris: L.G.D.J., 2001.

. Le droit international privé à l'épreuve de la hiérarchie des normes (l'exemple du droit de la famille). Revue Critique de Droit International Privé, Paris, v. 90, n. 1, p. 1$42,2001$.

GANNAGÉ, Pierre. La pénétration de l'autonomie de la volonté dans le droit international privé de la famille. Revue Critique de Droit International Privé, Paris, v. 81, n. 3, p. 425-454, 1992.

GANSHOF, Louis F.; BUGGENHOUT, Christian van. La protection des biens des mineurs dans les relations internationales. Revue Belge de Droit International, Bruxelles, v. 15, n. 1, p. 149-164, 1980.

GAUDEMET-TALLON, Hélène. La désunion du couple en droit international privé. Recueil des Cours, Dordrecht/Boston/Lancaster: Martinus Nijhoff Publishers, v. 226, p. 9-280, 1991.

GAUTIER, Pierre-Yves. Les couples internationaux de concubins. Revue Critique de Droit 
International Privé, Paris, v. 80, n. 3, p. 525-539, 1991.

GERBER, David J. System Dynamics: toward a language of comparative law? The American Journal of Comparative law, Berkeley, v. 46, n. 4, p. 719-737, 1998.

GHERSI, Carlos Alberto. Cuantificación económica de los alimentos. Buenos Aires: Astrea, 2000.

GLANZ, Semy. A família mutante: sociologia e direito comparado. Rio de Janeiro: Renovar, 2005.

GOLDSTEIN, Joseph I. ¿En el interés superior de quién?. In: BELOFF, Mary (org.). Derecho, infancia y familia. Barcelona: Gedisa, 2000.

GOMES, Isabel Cristina. Alcances e limites da psicoterapia analítica com casais e famílias.

In. FÉRES-CARNEIRO, Terezinha (org.). Família e casal: arranjos e demandas contemporâneas. Rio de Janeiro: PUC-Rio; São Paulo: Loyola, 2003.

GRISARD FILHO, Waldir. Guarda compartilhada: um novo modelo de responsabilidade parental. 3. ed. São Paulo: RT, 2006.

Guarda compartilhada: quem é o melhor para decidir a respeito? Revista Jurídica, Porto Alegre, v. 47, n. 268, p. 28-31, 2000.

GROUD, Thomas Habu. La preuve en droit internacional privé. Aix-en-Provence: Presses Universitaires d'Aix-Marseille, 2000.

GRÜNSPUN, Haim. A guarda dos filhos e o melhor interesse da criança. Revista do Advogado, São Paulo, n. 25, p. 83-89, maio 1988.

GUARNERI, Attilio. Lineamenti di diritto comparato. Padova: Cedam, 2003.

GUTZWILLER, Max. Le développement historique du droit international privé. Recueil des Cours, Paris: Librairie Hachette, v. 29, p. 287-394, 1929.

HAESBERT, Rogério. Migração e desterritorialização. In: PÓVOA NETO, Helión; FERREIRA, Ademir Pacelli (Org.). Cruzando fronteiras disciplinares: um panorama dos estudos migratórios. Rio de Janeiro: Revan - FAPERJ, 2005.

HELZICK, Cathy S. Returning United States children abducted to foreign countries: the need to implement the Hague Convention on the Civil Aspects of International Child 
Abductions. Boston University International Law Journal, p. 119-152, 1987 (HeinOnLine).

HÉRON, Jacques. L'application dans le temps des règles de conflit. Revue Critique de Droit International Privé, Paris, v. 76, n. 2, p. 305-350, 1987.

HERRANZ BALLESTEROS, Mónica. El interés del menor en los convenios de la Conferencia de La Haya de Derecho Internacional Privado. Valladolid: Lex Nova, 2004.

HOLLEAUX, Dominique; FOYER, Jacques; GEOUFFRE DE LA PRADELLE, Géraud. Droit international privé. Paris: Masson, 1987.

HOOGSTRATEN, M. H. van. La codification par traités in droit international privé dans le cadre de la conférence de la Haye. Recueil de Cours, La Haye, v. 122, p. 337-425, n. III, 1967.

HOUTTE, Hans van. La réciprocité des règles de conflit dans les conventions de la Haye. Revue Belge de Droit International, Bruxelles, v. 24, n. 2, p. 491-503, 1991.

IGLESIAS BUHIGES, José Luis. Reflexiones en torno al objeto y función del derecho internacional privado. Revista Española de Derecho Internacional, Madrid, v. 35, n. 1, p. 29-42, 1983.

ITERSON, Dorothea van. The New Hague Convention on the Protection of Children: A View from the Netherlands. Uniform Law Review/Revue de Droit Uniforme, Paris, n. 3, p. 474-487, 1997.

JABLONSKI, Bernardo. Afinal, o que quer um casal? In: FÉRES-CARNEIRO, Terezinha (Org.). Família e casal: arranjos e demandas contemporâneas. Rio de Janeiro: PUCRio; São Paulo: Loyola, 2003.

JANOT, Leda Maria Soares. Direito Comparado: ciência jurídica ou método comparativo. Revista da Procuradoria-Geral da República, São Paulo, n. 2, p. 135-154, 1993.

JÄNTERÄ-JAREBORG, Maarit. The influence of the Hague conventions on the development of Swedish family conflicts law. Netherlands International Law Review, The Hague, v. 40, n. 1, p. 49-65, 1993. 
JAYME, Erik. Diritto di famiglia: società multiculturale e nuovi sviluppi del diritto internazionale privato. Rivista di Diritto Internazionale Privato e Processuale, Padova, v. 29, n. 2, p. 295-304, 1993.

Identité culturelle et intégration: le droit international privé postmoderne. Recueil des Cours, Dordrecht/Boston/Lancaster: Martinus Nijhoff Publishers, v. 251, p. 9-268, 1995.

Le droit international privé du nouveau millénaire: la protection de la personne humaine face à la globalisation. Recueil des Cours, Hague/Boston/London: Martinus Nijhoff Publishers, v. 282, p. 9-40, 2000.

- O direito internacional privado e a família no umbral do século XXI. In: MARQUES, Claudia Lima; ARAUJO, Nadia de. O novo direito internacional: estudos em homenagem a Erik Jayme. Rio de Janeiro: Renovar, p. 21-28, 2005.

JENARD, P. Les enlèvements internationaux d'enfants et l'administration. Revue Belge de Droit International, Bruxelles, v. 21, n. 1, p. 35-59, 1988.

JORGE JUNIOR, Alberto Gosson. Guarda, tutela e adoção no Estatuto da Criança e do Adolescente: principais aspectos. Revista de Direito Privado, São Paulo, ano 2, v. 5, p. 24-71, 2001.

KATIČIĆ, Natko. Le droit international privé dela Yougoslavie dans le domaine des rapports familiaux et successoraux. Recueil des Cours, Leyde: A. W. Sijthoff, v. 131, p. 393-488, 1971.

KEARNEY, Richard D. Developments in private international law. American Journal of International Law, Lancaster, v. 81, n. 3, p. 724-739, 1987.

KESSEDJIAN, Catherine. Codification du droit commercial international et droit international privé: de la gouvernance normative pour les relations économiques transnationales. Recueil des Cours, La Haye, v. 300, p. 79-308, 2002

KOTUBY Jr, Charles T. External competence of the european community in the Hague Conference of Private International Law: community harmonization and worldwide unification. Netherlands International Law Review, The Hague, v. 48, n. 1, p. 1-30, 2001. 
LAGARDE, Paul. La convention de la Haye du 13 janvier 2000 sur la protection internationale des adultes. Revue Critique de Droit International Privé, Paris, v. 89, n. 2, p. 159-179, 2000.

La nouvelle convention de la Haye sur la protection des mineurs. Revue Critique de Droit International Privé, Paris, v. 86, n. 2, p. 217-237, 1997.

La protection du mineur double-national talon d'achille de la Convention de La Haye du 5 octobre 1961. L'unificazione del diritto internazionale privato e processuale - Studi in memoria di Mario Giuliano. Padova: Cedam, p. 529-542, 1989.

La réciprocité en droit international privé. Recueil des Cours, Alphen aan den Rijn: Sijthoff \& Noordhoff, v. 154, p. 103-214, 1977.

LAURIA, Flávio Guimarães. A regulamentação de visitas e o princípio do melhor interesse da criança. 2. tir. Rio de Janeiro: Lumen Juris, 2003.

LÁZZARO, Héctor Eduardo. La patria potestad en el derecho romano. In: LÓPEZ-ROSA, Ramón; PINO-TOSCANO, Ramón (Org.). El derecho de familia: de Roma al derecho actual. Huelva: Universidad de Huelva, 2004.

LeGETTE, Caroline. International Child Abduction and The Hague Convention: Emerging Practice and Interpretation of the Discretionary Exception. Texas International Law Journal, v. 25, n. 2, p. 287-308, 1990 (HeinOnLine).

LEITE DE CAMPOS, Diogo. Lições de Direito da Família e das Sucessões. 2. ed. Coimbra: Almedina, 2005.

LEITE, Eduardo de Oliveira. Le droit (non sacré) de visite. In POUSSON-PETIT, Jacqueline (org.). Liber Amicorum Marie-Thérèse Meulders-Klein: droit comparé des personnes et de la famille. Bruxelles: Bruylant, p. 161-179, 1998.

LEQUETTE, Yves. Le droit international privé de la famille à l'épreuve des conventions internationales. Recueil des Cours, Dordrechts/Boston/London: Martinus Nijhoff Publishers, v. 246, p. 9-233, 1995.

LEROYER, Anne-Marie. L'enfant confié à un tiers: de l'autorité parentale à l'autorité familiale. Revue Trimestrielle de Droit Civil, Paris, v. 97, n. 3, p. 587-606, 1998. 
LÔBO, Paulo Luiz Netto. Entidades familiares constitucionalizadas: para além do numerus clausus. Revista Brasileira de Direito de Família, Porto Alegre, n. 12, p. 40-55, 2002.

LOON, Hans van. The Implementation and Enforcement of the Hague Convention of 25 October 1980 on the Civil Aspects of International Child Abduction in comparative perspective: It's Japan's move! Gender Law and Policy Annual Review, v. 2, p. 189209, 2004.

LOWE, Nigel; PERRY, Alison. International child abduction: the English experience. International and Comparative Law Quarterly, London, v. 48, n. 1, p. 127-148, 1999.

MAGALHÃES COLLAÇO, Isabel Maria de. Da qualificação em direito internacional privado. Lisboa: s/e, 1964.

MAKIANICH DE BASSET, Lidia Noemi. Derecho de visitas: régimen jurídico del derecho y deber de adecuada comunicación entre padres e hijos. $1^{\mathrm{a}}$ reimp. Buenos Aires: Editorial Hammurabi, 1997.

MAKIANICH DE BASSET, Lidia Noemi; GUTIERREZ, Délia. L'Argentine et la Convention sur les aspects civils de l'enlèvement international d'enfants. L'enfant et les conventions internationales. Presses Universitaires de Lyon, p. 163-170, 1996.

MALHEIROS FILHO, Fernando. Os princípios e a casuística na guarda dos filhos. Revista de Direito Privado, São Paulo, ano 3, v. 10, p. 107-127, 2002.

MARACCINNI, Eliane Michelini; MOTTA, Maria Antonieta Pisano. Guarda dos filhos: algumas diretrizes psicanalíticas. Revista dos Tribunais, São Paulo, v. 84, n. 716, p. 346-357, 1995.

MARLASCA MARTÍNEZ, Olga. Capacidad patrimonial de los hijos que están bajo la potestas del padre. In: LÓPEZ-ROSA, Ramón; PINO-TOSCANO, Ramón (Org.). El derecho de familia: de Roma al derecho actual. Huelva: Universidad de Huelva, 2004.

MARQUES, Cláudia Lima. Casos de divórcios japoneses no Brasil: introdução ao método de análise de casos. Revista da Faculdade de Direito da Universidade do Rio Grande do Sul, Porto Alegre, número especial, p. 150-156, set. 2002.

O direito internacional privado solucionando conflitos de cultura: os divórcios no Japão e seu reconhecimento no Brasil. Revista de Informação Legislativa, Brasília, v. 
41, n. 162, p. 91-113, 2004.

Novos rumos do direito internacional privado quanto às obrigações resultantes de atos ilícitos (em especial de acidentes de trânsito). Revista dos Tribunais, São Paulo, v. 77, n. 629, p. 72-92, 1988.

MARQUES, Cláudia Lima; CACHAPUZ, Maria Cláudia; VITORIA, Ana Paula da Silva. Igualdade entre filhos no direito brasileiro atual: direito pós-moderno? Revista dos Tribunais, São Paulo, v. 88, n. 764, p. 11-32, 1999.

MARQUES DOS SANTOS, António. Breves considerações sobre a adaptação em direito internacional privado. In: Estudos de direito internacional privado e de direito processual civil internacional. Coimbra: Almedina, p. 51-128, 1998.

Direito internacional privado. 2. ed. Coimbra: Almedina, 2005.

Direito internacional privado. Lisboa: Associação Académica da Faculdade de Direito de Lisboa, 2000.

Direito internacional privado. In: MARQUES, Claudia Lima; ARAUJO, Nadia de. O novo direito internacional: estudos em homenagem a Erik Jayme. Rio de Janeiro: Renovar, p. 29-55, 2005.

MARTINY, Dieter. Maintenance obligations in the conflict of laws. Recueil des Cours, Dordrecht/Boston/Lancaster: Martinus Nijhoff Publishers, v. 247, p. 131-288, 1994.

MAYER, Danièle. Évolution du statut de la famille en droit international privé. Journal du Droit International, Paris, n. 2, p. 447-469, abr-jun 1977.

$M^{c}$ CLEAN, David. The Hague child abduction convention - the common law response. Netherlands International Law Review, The Hague, v. 40, n. 1, p. 67-78, 1993.

$\mathrm{M}^{\mathrm{c}}$ ELEAVY, Peter. The Brussels II regulation: how the european community has moved into family law. International and Comparative Law Quarterly, London, v. 51, n. 4, p. 883-908, 2002.

MEBROUKINE, Ali. La convention algéro-française du 21 juin 1988 relative aux enfants de couples mixtes séparés. Le point de vue d'un Algérien. Revue Critique de Droit International Privé, Paris, v. 80, n. 1, p. 1-39, 1991. 
MENGOZZI, Paolo. La condizione di reciprocità e il diritto internazionale privato. Rivista di Diritto Internazionale Privato e Processuale, Padova, v. 30, n. 3, p. 485-498, 1994.

MIRAGEM, Bruno. Conteúdo da ordem pública e os direitos humanos. Elementos para um direito internacional privado pós-moderno. In: MARQUES, Claudia Lima; ARAUJO, Nadia de. O novo direito internacional: estudos em homenagem a Erik Jayme. Rio de Janeiro: Renovar, p. 307-354, 2005.

MONACO, Gustavo Ferraz de Campos. A Lei de Introdução, O Código Civil de 2002 e seu enfoque espaço-temporal. In: HIRONAKA, Giselda Maria Fernandes Novaes (coord). Novo Código Civil: interfaces no ordenamento jurídico brasileiro. Belo Horizonte: Del Rey, p. 1-18, 2004.

. A proteção da criança no cenário internacional. Belo Horizonte: Del Rey, 2005.

Atribuição da guarda na desunião dos pais: reconstrução do instituto a partir da figura primária de referência. In: DELGADO, Mário; FIGUEIREDO, Jones. Questões controvertidas no novo Código Civil. São Paulo: Método, 2005, v. 3, p. 105-128.

. Direitos da criança e adoção internacional. São Paulo: RT, 2002.

MONACO, Gustavo Ferraz de Campos; CAMPOS, Maria Luiza Ferraz de. O direito de audição de crianças e jovens em processo de regulação do exercício do poder familiar. Infância e Juventude, Lisboa, n. 1, p. 9-25, 2006.

MONTANARI, Michela. Giurisdizione e riconoscimento delle decisioni sulla protezione del minore bipolide tra convenzione dell'Aja del 1961 e diritto comune. Rivista di Diritto Internazionale Privato e Processuale, Padova, v. 38, n. 1, p. 99-118, 2002.

MOTTA, Maria Antonieta Pisano. Busca e apreensão de filho: uma medida de proteção?. Revista Brasileira de Direito de Família, Porto Alegre, ano 1, n. 2, p. 150-163, 1999.

MOURA RAMOS, Rui Manuel Gens de. Da lei aplicável ao contrato de trabalho internacional . Coimbra: Almedina, 1990.

. Direito internacional privado e Constituição: introdução a uma análise das suas relações. Coimbra: Coimbra, 1994.

Droit international prive vers la fin du vingtieme siecle: avancement ou recul? Documentação e Direito Comparado: Boletim do Ministério da Justiça, Lisboa, n. 
73/74, p. 85-125, 1998.

La protección de los menores en el âmbito internacional - las nuevas normas convencionales de La Haya aplicables a la protección de menores en supuestos de conexión múltiple. Estatuto personal y multiculturalidad de la familia. Madrid: Colex, p. $67-84,2000$.

Les clauses d'exception en matiere de conflits de lois et de conflits de juridictions. Documentação e Direito Comparado: Boletim do Ministério da Justiça, Lisboa, n. 57/58, p. 293-322, 1994.

O Tribunal de Justiça das Comunidades Européias e a teoria geral do Direito Internacional Privado: desenvolvimentos recentes. In: Estudos em homenagem à Professora Doutora Isabel de Magalhães Collaço. Coimbra: Coimbra, p. 431-467, 1994 (separata).

NASCIMBENE, Bruno. Il minore straniero e le norme sull'immigrazione. Rivista di Diritto Internazionale Privato e Processuale, Padova, v. 25, n. 4, p. 809-820, 1989.

NERY JUNIOR, Nelson; MACHADO, Martha de Toledo. O estatuto da criança e do adolescente e o novo Código Civil à luz da Constituição Federal. Revista de Direito Privado, São Paulo, ano 3, v. 12, p. 9-49, 2002.

NIBOYET, J.-P. La notion de réciprocité dans les traités diplomatiques de droit international privé. Recueil des Cours, Paris: Librairie du Recueil Sirey, v. 52, p. $253-$ $363,1935$.

Le rôle de la justice internationale en droit international privé: conflit des lois. Recueil des Cours, Paris: Librairie du Recueil Sirey, v. 40, p. 153-236, 1932.

NYGH, Peter E. The New Hague Convention on Child Protection. Australian Journal of Family Law, v. 11, p. 5-10, 1997.

. The Hague convention on the protection of children. Netherlands international law review, The Hague, v. 45, n. 1, p. 1-28, 1998.

OVERBECK, Alfred Eugene von. L'application par le juge interne des conventions de droit international privé. Recueil des Cours, Leyde: A. W. Sijthoff, v. 132, p. 1-106, 1971. 
L'image de l'enfant en droit international privé conventionnel. L'image de l'homme en droit. Fribourg: Editions Universitaires Fribourg Suisse, p. 383-403, 1990.

PAIS, Marta Santos. Enfants deplaces: comment garantir leur droit a une vie de famille. Documentação e Direito Comparado: Boletim do Ministério da Justiça, Lisboa, n. 6566, p. 79-88, 1996.

PANICO, Ruggiero Cafari. Diritto internazionale privato inglese e "jurisdiction" con particolare riguardo ai rapporti di famiglia. Padova: Cedam, 1979.

PARRA-ARANGUREN, Gonzalo. La restitución de menores en el derecho convencional americano. In: Hacia un Nuevo Orden Internacional y Europeo: Estudios en Homenaje al Profesor Don Manuel Díez de Velasco. Madrid: Tecnos, p. 1401-1418, 1993.

La tarea complementaria de la Convención de las Naciones Unidas sobre los Derechos del Niño realizada por las Convenciones de la Conferencia de La Haya de Derecho Internacional Privado. Revista de la Facultad de Ciencias Jurídicas y Políticas, Caracas, n. 106, p. 51-67, 1998.

PEREIRA, Áurea Pimentel. Da proteção da pessoa dos filhos na dissolução da sociedade conjugal: tratamento dado pela legislação brasileira. Revista Doutrinária, Rio de Janeiro, v. 4, n. 4, p. 49-53, 2001.

Divórcio e separação judicial no novo Código Civil. 11. ed. Rio de Janeiro: Renovar, 2004.

PEREIRA, Luís Cezar Ramos. Prestação de alimentos no direito internacional privado brasileiro. Revista dos Tribunais, São Paulo, ano 82, v. 690, p. 29-38, 1993.

PÉREZ VERA, Elisa. El menor en los convenios de la Conferencia de la Haya de Derecho Internacional Privado. Revista Española de Derecho Internacional, Madrid, v. 45, n. 1, p. 101-114, 1993.

PFUND, Peter H. The Developing Jurisprudence of the Rights of the Child: Contributions of the Hague Conference on Private International Law. ILSA Journal of International and Comparative Law, v. 3, p. 665-675, 1997.

PICONE, Paolo. La nuova convenzione dell'Aja sulla protezione dei minori. Rivista di Diritto Internazionale Privato e Processuale, Padova, v. 32, n. 4, p. 705-748, 1996. 
PINHEIRO, Luís de Lima. Direito internacional privado, v. 1. 2. reimpr. Coimbra: Almedina, 2005.

. Direito internacional privado, v. 2. reimpr. da 2. ed. Coimbra: Almedina, 2005. . Direito internacional privado, v. 3. Coimbra: Almedina, 2002. . Um direito internacional privado para o século XXI. Suplemento da Revista da Faculdade de Direito da Universidade de Lisboa, Lisboa, 2001.

POCAR, Fausto. La protection de la partie faible en droit international privé. Recueil des Cours, Dordrecht/Boston/Lancaster: Martinus Nijhoff Publishers, v. 188, p. 339-417, 1984.

PONSARD, André. L'office du juge et l'application du droit étranger. Revue Critique de Droit International Privé, Paris, v. 79, n. 4, p. 607-619, 1990.

PONTES DE MIRANDA, Francisco Cavalcanti. La conception du droit international privé d'après la doctrine et la pratique au Brésil. Recueil des Cours, Paris: Librairie du Recueil Sirey, v. 39, p. 551-678, 1932.

QUADRI, Assunto. Qualche considerazione sul rischio in età evolutiva. In: DELL'ANTONIO, Anna Maria (Org.). Minori a rischio e istituzioni. Milano: Giuffrè, 1996.

RAAPE, Léo. Les rapports juridiques entre parents et enfants comme point de départ d'une explication pratique d'anciens et de nouveaux problèmes fondamentaux du droit international privé. Recueil des Cours, Paris: Librairie du Recueil Sirey, v. 50, p. $402-$ 544, 1934.

RAMOS, Patricia Pimentel de Oliveira Chambers. O poder familiar e a guarda compartilhada sob o enfoque dos novos paradigmas do Direito de Família. Rio de Janeiro: Lumen Juris, 2005.

REIS, Dagma Paulino dos. O homossexualismo e a discriminação do direito na vida social e familiar. Revista Jurídica, Porto Alegre, v. 47, n. 269, p. 14-18 (extrato do texto), 2000.

REITZ, John C. How to do comparative law. The American Journal of Comparative law, 
Berkeley, v. 46, n. 4, p. 617-636, 1998.

REZENDE, Joubert R. Direito à visita ou poder-dever de visitar: o princípio da afetividade como orientação dignificante no direito de família humanizado. Revista Brasileira de Direito de Família, Porto Alegre, ano 6, n. 28, p. 150-160, 2005.

RIBEIRO, Marilda Rosado de Sá. Importância do direito comparado. In: TIBURCIO, Carmen; BARROSO, Luís Roberto (Org.). O Direito Internacional contemporâneo. Estudo em homenagem ao Professor Jacob Dolinger. Rio de Janeiro: Renovar, p. 679$692,2006$.

RICHMAN, Kimberly. Lovers, legal strangers and parents: negotiating parental and sexual identity in family law. Law and Society Review, Denver, v. 36, n. 2, p. 285-291 (extrato do texto), 2002.

RIGAUX, François. Droit privé matériel et règles de conflit de lois. Revue Belge de Droit International, Bruxelles, v. 24, n. 2, p. 385-397, 1991.

Le statut des mineurs, l'autorité parentale et les obligations alimentaires en droit international privé. Tijdschrift voor Privaatrecht, Belgique, v. 19, p. 311-326, 1982.

ROCHA, Maria Isabel de Matos. Criança "devolvida". Quais são os seus direitos? Revista de Direito Privado, São Paulo, ano 1, v. 2, p. 74-113, 2000.

RODAS, João Grandino. Direito internacional privado brasileiro. São Paulo: RT, 1993. Prefácio. In: MONACO, Gustavo Ferraz de Campos. Direitos da criança e adoção internacional. São Paulo: RT, 2002.

RODAS, João Grandino; MONACO, Gustavo Ferraz de Campos. A Conferência da Haia de Direito Internacional Privado: a participação do Brasil. Brasília: Fundação Alexandre de Gusmão, 2007.

RODRIGUES, Silvio. Comentários ao Código Civil, v. 17. Coord. Antônio Junqueira de Azevedo. São Paulo: Saraiva, 2003.

ROUDINESCO, Elisabeth. A família em desordem [La famille en desórdre]. Trad. André Telles. Rio de Janeiro: Jorge Zahar, 2003.

RUBELLIN-DEVICHI, Jacqueline (Dir.). Droit de la famille. Paris: Dalloz, 2001. 
SÁ, Eduardo. Encontros com a ternura. In: SÁ, Eduardo et alli. Abandono e adopção. Coimbra: Almedina, 2005.

SÁNCHEZ LORENZO, Sixto A. Postmodernismo y derecho internacional privado. Revista Española de Derecho Internacional, Madrid, v. 46, n. 2, p. 557-585, 1994.

SANSEVERINO, Paulo de Tarso Vieira. Métodos de interpretação da lei no direito comparado. Ajuris: Revista da Associação dos Juízes do Rio Grande do Sul, Porto Alegre, ano 22, n. 64, p. 103-131, 1995.

SANTOS, Eduardo dos. Direito da família. 2.ed. Coimbra: Almedina, 1999.

SAVIGNY, Friedrich Carl von. Sistema do Direito Romano atual [System des Heutigen Römischen Rechts]. Trad. Ciro Mioranza. v. 8. Ijuí: Unijuí, 2004.

SCHREIBER, Elisabeth. Os direitos fundamentais da criança na violência intrafamiliar. Porto Alegre: Ricardo Lenz Editor, 2001.

SCHUZ, Rhona. The Hague child abduction convention: family law and private international law. International and Comparative Law Quarterly, London, v. 44. n. 4, p. 771-802, oct. 1995.

SCHWIND, Fritz. Aspects et sens du droit international privé. Recueil des Cours, Dordrecht/Boston/Lancaster: Martinus Nijhoff Publishers, v. 187, p. 9-144, 1984.

. Le divorce en droit international privé. Recueil des Cours, Leyde: A. W. Sijthoff, v. 117, p. $445-502,1966$.

SELTZER, Judith A. Legal custody arrangements and children's economic welfare. AJS: American Journal of Sociology, Chicago, v. 96, n. 4, p. 895-929, 1991.

SHAPIRA, Amos. Private International Law aspects of child custody and child kidnapping cases. Recueil des Cours, La Haye, n. 214, p. 127-250, 1989.

SHECAIRA, Sérgio Salomão; SILVEIRA, Renato de Mello Jorge. O tráfico Internacional de Mulheres e Crianças. Boletim do Instituto Brasileiro de Ciências Criminais, São Paulo, ano 10, n. 112, p. 3-4, 2002.

SHINE, Sidney. A espada de Salomão: a psicologia e a disputa de guarda de filhos. São Paulo: Casa do psicólogo, 2003. 
SILVA, Nuno Ascensão. Algumas considerações sobre os trabalhos do Conselho da Europa no contexto do movimento de internacionalização do direito de menores - o rapto de crianças e os direitos de guarda e visita nas relações privadas internacionais. Lex Familiae: Revista Portuguesa de Direito de Família, Coimbra, ano 2, n. 4, p. 37 91, 2005.

SMEETS, Carla. Um advogado das crianças. Infância e Juventude, Lisboa, n. 2, p. 43-60, 2003.

SOŚNIAK, Mieczyslaw. Les conventions conclues entre les pays socialistes sur le droit civil international et le droit international de la famille. Recueil des Cours, Leyde: A. W. Sijthoff, v. 144, p. 1-76, 1975.

SOTTOMAYOR, Maria Clara. Divórcio, poder paternal e realidade social: algumas questões. Direito e Justiça: Revista da Faculdade de Direito da Universidade Católica Portuguesa, Lisboa, v. 11. n. 2, p. 161-172, 1997.

O poder paternal como cuidado parental e os direitos da criança. In:

(Coord.). Cuidar da Justiça de crianças e jovens: a função dos juízes sociais. Coimbra: Almedina, 2003.

STEIGER, Werner E von. La protection des mineurs en droit international privé. Recueil des Cours, Leyde: A. W. Sijthoff, v. 112, p.469-525, 1964.

STILERMAN, Marta N. Menores. Tenencia. Régimen de visitas. 3. ed. Buenos Aires: Editorial Universidad, 1997.

STRENGER, Guilherme Gonçalves. Interesse do menor na atribuição da guarda. IOB Repertório de Jurisprudência: Civil, Processual, Penal e Comercial, São Paulo, n. 19, p. 525-524, out. 2002.

STRENGER, Irineu. Direito internacional privado. 6. ed., São Paulo: LTr, 2005.

SZÁSZY, István. Le conflit de lois interpersonnel dans le pays en voie de développement. Recueil des Cours, Leyde: A. W. Sijthoff, v. 138, p. 81-202, 1974.

TANAKA, Áurea Christine. O divórcio dos brasileiros no Japão: o direito internacional privado e os princípios constitucionais. São Paulo: Kaleidos Primus, 2005.

TEIXEIRA, Ana Carolina Brochado. Direito de visita dos avós. Revista Trimestral de 
Direito Civil, Rio de Janeiro, ano 3, v. 10, p. 59-77, 2002.

. Família, guarda e autoridade parental. Rio de Janeiro: Renovar, 2005.

TENÓRIO, Oscar. Direito internacional privado. 11. ed. Rio de Janeiro: Freitas Bastos, 1976, 2. v.

TOPOR, Lucienne. Les conflits de lois en matière de puissance parentele. Paris: Dalloz, 1971.

URIONDO DE MARTINOLI, Amalia. Convención interamericana sobre tráfico internacional de menores - CIDIP V - México, 1994. Revista de la Facultad de Derecho y Ciencias Sociales. Universidad Nacional de Córdoba, Córdoba (Argentina), v. 3, n. 1, p. 171-197, 1995.

VALLADÃO, Haroldo. Conséquences de la difference de nationalité ou de domicile des époux sur les effets et la dissolution du mariage. Recueil des Cours, Leyde: A. W. Sijthoff, v. 105, p. 69-172, 1963.

Développement et intégration du droit international privé, notamment dans le rapports de famille (cours général de droit international privé). Recueil des Cours, Leyde: A. W. Sijthoff, v. 133, p. 413-528, 1971.

Direito internacional privado. 2. ed. Rio de Janeiro: Freitas Bastos, 1970.

VARELA, J. Antunes. Das obrigações em geral. 10. ed., v. 1, Coimbra: Almedina, 2000.

VERWILGHEN, Michel; HOUTTE, Hans van. Conflits d'autorites et de juridictions relatifs a la protection de la personne du mineur. Revue Belge de Droit International, Bruxelles, v. 15, n. 2, p. 397-432, 1980.

VICENTE, Dário Moura. Direito Internacional Privado - Ensaios, v. 1. Coimbra: Almedina, 2002.

VILLELA, Anna Maria. L'unification du droit international privé en Amérique latine. Revue Critique de Droit International Privé, Paris, v. 73, n. 2, p. 233-265, 1984.

Le droit international privé brésilien et la question du divorce. Revue Critique de Droit International Privé, Paris, v. 69, n. 2, p. 231-278, 1980.

VILLELA, João Baptista. Desbiologização da paternidade. Revista Forense, Rio de 
Janeiro, v. 271, p. 45-51, 1980.

Liberdade e Família. Movimento Editorial da Revista da Faculdade de Direito da UFMG, Belo Horizonte, v. 3, série Monografias, n. 2, p. 16-46, 1980.

VRELLIS, Spyridon. Le droit international privé vers la fin du vingtième siècle: avancement ou recul? Revue Hellénique de Droit International, Atenas, v. 51, n. 1, p. 103-122, 1998.

WAI, Robert. Transnational liftoff and juridical touchdown: the regulatory function of private international law in an era of globalization. Columbia Journal of Transnational Law, New York, v. 40, n. 2, p. 209-274, 2002.

WATT, Horatia Muir. La codification en droit international privé. Droits: Revue Française de Théorie, de Philosophie et de Culture Juridiques, Paris, n. 27, p. 149-160, 1998.

WATT, Horatia Muir; ANCEL, Bertrand. La désunion européenne: le réglement dit 'Bruxelles II'. Revue Critique de Droit International Privé, Paris, v. 90, n. 3, p. 403457, 2001.

WATTÉ, Nadine. L'autonomie de la volonté dans les conventions de la Haye. Revue Belge de Droit International, Bruxelles, v. 24, n. 2, p. 413-437, 1991.

WEINBERG. Inés M. Protección integral de la familia. In: (Dir.). Convención sobre los Derechos del Niño. Buenos Aires: Rubinzal-Culzoni, 2002.

YASSEEN, Mustafa Kamil. Principes généraux de droit international privé. Recueil des Cours, Leyde: A. W. Sijthoff, v. 116, p. 383-470, 1965.

YOKARIS, Angelos. Problèmes méthodologiques et nature de la recherche comparative en droit international. Revue Hellénique de Droit International, Atenas, v. 35-36, n. 1-4, p. 65-96, 1982-1983.

YOUF, Dominique. Penser les droits de l'enfant. Paris: Presses Universitaires de France, 2002. 
A NEX O

Lista das principais convenções analisadas $e$

indicação dos sítios de publicação virtual na rede mundial de computadores

CONVENTION CONCERNANT LA COMPETENCE, LA LOI APPLICABLE, LA RECONNAISSANCE, L'EXECUTION ET LA COOPERATION EN MATIERE DE RESPONSABILITE PARENTALE ET DE MESURES DE PROTECTION DES ENFANTS (1996)

$>\quad$ Versão autêntica em língua francesa:

http://www.hcch.net/index_fr.php?act=conventions.text\&cid=70

$>\quad$ Versão autêntica em língua inglesa:

http://www.hcch.net/index_en.php?act=conventions.text\&cid=70

\section{CONVENÇÃO SOBRE OS ASPECTOS CIVIS DO SEQÜESTRO INTERNACIONAL DE CRIANÇAS (1980)}

$>\quad$ Versão autêntica em língua francesa:

http://www.hcch.net/index_fr.php?act=conventions.text\&cid=24

$>\quad$ Versão autêntica em língua inglesa:

http://www.hcch.net/index_en.php?act=conventions.text\&cid=24

$>\quad$ Decreto Executivo n. 3.413, de 14 de abril de 2000:

http://www6.senado.gov.br/legislacao/ListaPublicacoes.action?id=229533

\section{CONVENÇÃO INTERAMERICANA SOBRE RESTITUIÇÃO INTERNACIONAL DE MENORES (1989)}

> Versão autêntica em língua espanhola:

http://www.oas.org/juridico/spanish/tratados/b-53.html 
$>\quad$ Versão autêntica em língua inglesa:

http://www.oas.org/juridico/english/treaties/b-53.htm

$>\quad$ Versão autêntica em língua portuguesa:

http://www.oas.org/juridico/portuguese/treaties/B-53.htm

Decreto Executivo n. 1.212, de 3 de agosto de 1994:

http://www6.senado.gov.br/legislacao/ListaPublicacoes.action?id=139738

CONVENTION SUR LA LOI APPLICABLE AUX OBLIGATIONS

ALIMENTAIRES (1973)

$>\quad$ Versão autêntica em língua francesa:

http://www.hcch.net/index_fr.php?act=conventions.text\&cid=86

$>\quad$ Versão autêntica em língua inglesa:

http://www.hcch.net/index_en.php?act=conventions.text\&cid=86

CONVENTION CONCERNANT LA RECONNAISSANCE ET L'EXECUTION DE DECISIONS RELATIVES AUX OBLIGATIONS ALIMENTAIRES (1973)

V Versão autêntica em língua francesa:

http://www.hcch.net/index_fr.php?act=conventions.text\&cid=85

$>\quad$ Versão autêntica em língua inglesa:

http://www.hcch.net/index_en.php?act=conventions.text\&cid=85

\section{CONVENTION SUR LE RECOUVREMENT INTERNATIONAL DES ALIMENTS DESTINÉS AUX ENFANTS ET À D’AUTRES MEMBRES DE LA FAMILLE}

$>\quad$ Versão não definitiva em língua inglesa:

http://www.hcch.net/index_en.php?act=conventions.text\&cid=131

V Versão não definitiva em língua francesa:

http://www.hcch.net/index_fr.php?act=conventions.text\&cid=131 